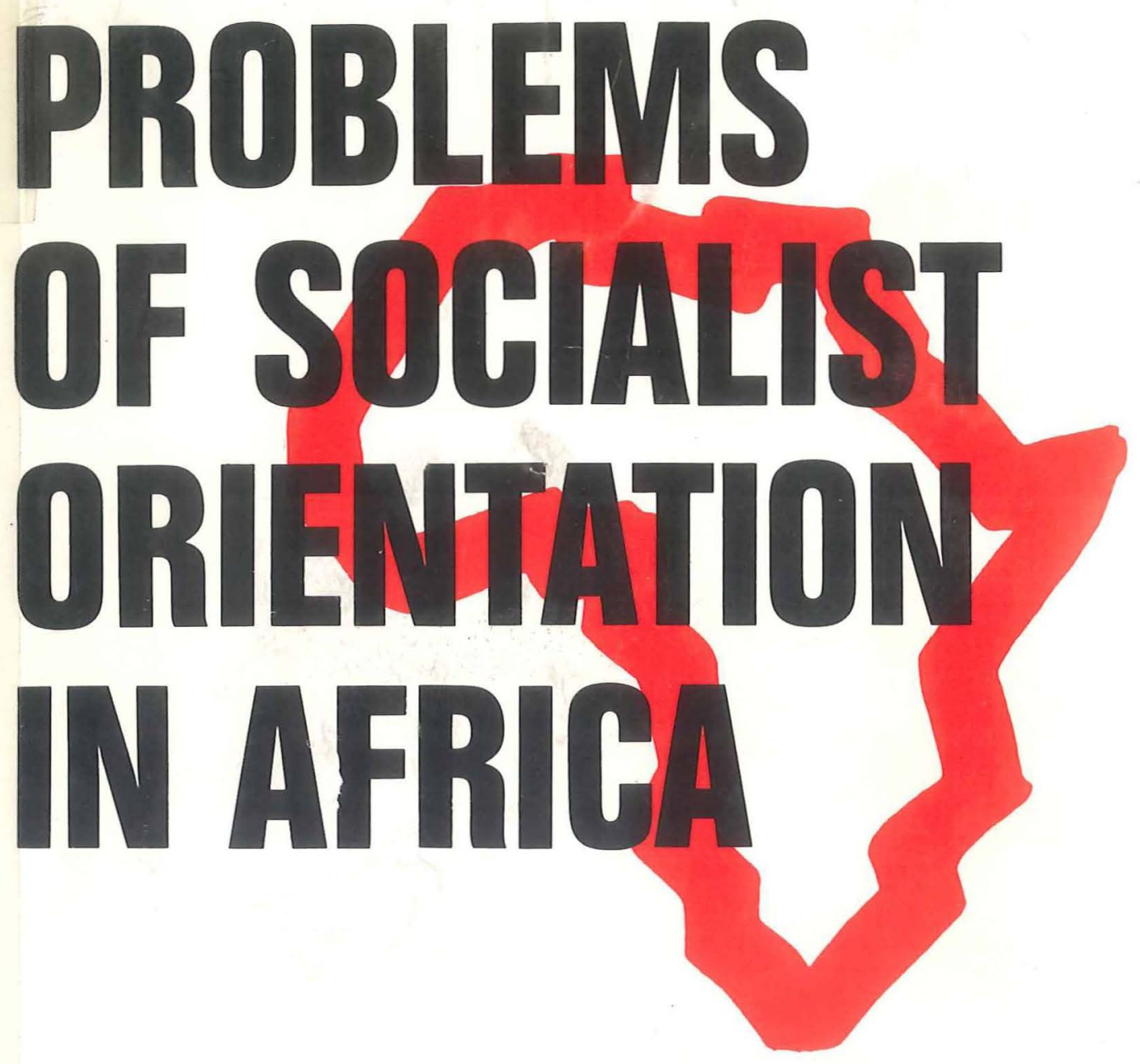

Edited by 


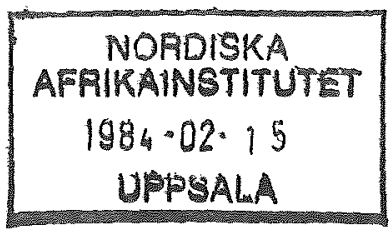





\section{Problems of Socialist Orientation in Africa}




\section{Problems of}

\section{Socialist Orientation}

in Africa

Edited by

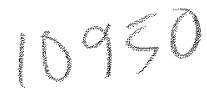

Mai Palmberg

Papers from a seminar on non-capitalist development in Africa organised by the Scandinavian Institute of African Studies, Uppsala, in co-operation with the Institute of Development Studies, Helsinki, August 16-19, 1976, in Helsinki, Finland.

Contributors: Mohamed Aden \& A.M.M. Ashur,Jeremy Gould \& Ritta Launonen, Parwiz, Khalatbari, Peter Mandi, Jozef Nowicki, Mai Palmberg, Lars Rudebeck, Timothy Shaw o Malcolm J. Grieve, Clive Y. Thomas

The Scandinavian Institute of African Studies Uppsala 1978

Distributed by Almquist \& Wiksell International, Stockholm 
(C) Nordiska afrikainstitutet 1978 ISBN $91.7106 \cdot 141 \cdot \mathrm{X}$

Printed in Sweden by Uppsala Offset Center AB, Uppsala 1978 


\section{PREFACE}

Since 1963, the Scandinavian Institute of African Studies has organized a variety of international seminars. As a part of its function as a Scandinavian documentation and research centre on African problems, the Institute has sought to choose topics for these international seminars that would be of interest to academics as well as to planners, administrators and politicians. These topics have included refugee problems, boundary problems, problems of adult education, the role of mass media, co-operative development in East Africa and problems of land-locked countries in Africa. Scholars from abroad - primarily, of course, from Africa - have been invited to discuss their particular topics with Scandinavian specialists and other interested persons.

Another of our principle tasks over the years has been to promote and sustain the interest in African affairs among Scandinavians. Seminars comprise one way of doing so at an academic level. During these seminars, however, we have also attempted to offer "another point of view" on a variety of topics. The profile, strength and vigour of our institute depends, therefore, to a great extent on our being able to call upon a large number of Scandinavian Scholars with backgrounds and views widely differing from those held in other African studies establishments, in our discussions with experts from Africa and abroad.

This years topic was chosen for several reasons, but the main reason was the general inaccesibility in the west of a collection of papers on a subject matter which has been extensively discussed in eastern Europa over the last decade.

The seminar was planned with the Afrika Institut of the USSR Academy of Science and the Institute of Development Studies of the University of Helsinki and held at Hanasaari, Helsinki in August 1976.

The Institute wishes to thank Mai Palmberg for organizing the immense conference material into one volume and also to express its gratitude to our Finnish co-sponsors for their participation in the organization of the conference.

Carl Widstrand 


\section{CONTENTS}

\section{PREFACE}

\section{Introduction}

Clive Y. Thomas: Class struggle, social development and

the theory of the non-capitalist path

Lionel Cliffe: A non-revolutionary transition to socialism?

Timothy Shaw \& Malcolm J. Grieve: Dependence or

development: international inequalities in Africa

Józef Nowicki: Non-capitalist agriculture and

development strategy

Parviz Khalatbari: Application of the marxist

reproduction model to the developing countries

Peter Mandi: The non-capitalist path and the new

international economic order

Jeremy Gould \& Riitta Launonen: Pitfalls along

the noncapitalist path - comments on the

genesis of indigenous capital in Africa

Mohamed Aden Sheck, Ahmed Mohamed Mohamoud "Ashur":

Socialist oriented development - the Somali

experience

Lars Rudebeck: Conditions of development and actual

development strategy in Guinea-Bissau

Perti Multanen: Problems of socialist orientation

in Nasser's Egypt

Mai Palmberg: The political role of the workers in Tanzania and Zambia

Reports from the working groups at the seminar on non-capitalist development in Africa, August 16-19, 1976 in Helsinki, Finland

Mai Palmberg: Literature on non-capitalist development 

Mai Palmberg

INTRODUCTION

In a famous speech, "The rational choice", early in 1973, President Nyerere of Tanzania, put forward his thesis that socialism was the only rational choice of economic and social system for the Third World countries characterised as they are by poverty and national weakness. "In fact", he said, "Third World capitalism would have no choice except to co-operate with external capitalism, as a very junior partner".

Socialism has meant many things in Africa. Ten years ago Julius Nyerere defined socialism as "an attitude of mind" in line with the various individual interpretations of a rather mystical "African socialism". The realities themselves have forced the discussion down from the philosophical clouds to the hard and concrete realities.

At the time when a great number of African states gained their political independence there were great expectations for a fast economic growth and social development. The "undeveloped" nations were to reach their "take-off" into industrialised society with the aid of Western development assistance, know-how, and investment capital. In fact, most African countries have followed the advice of the various Western advisors, but problems of economic and social development have remained unsolved. Instead of constructing their own economy they have become even more dependent on export markets, the investment and price policies of the multinational companies, and on foreign grants and loans. While a growing state bureaucracy is manned by Africans in a position to raise their own standard of living, as truly "junior partners", the great majority of peasants and workers have not been able to reap the fruits of independence.

Tanzania is one of those few countries in Africa, whose leadership have explicitly rejected this course of development, or one might say, this curse of development. There are others, like Algeria, whose massive industrialisation plan is one of the great socio-economic experiments on the African continent. The successful liberation struggle in the former Portuguese colonies have added the republics of Guinea-Bissau, Angola, and Mozambique to the African states intent on breaking the patterns of neo-colonial dependence. Other, still less discussed, examples include the Republic of Guinea (Conakry), The People's Republic of Congo, Benin (former Dahomey), Somali Democratic Republic and possibly Ethiopia. They all claim that their policies aim at the construction of socialism in their countries. 
Clearly, socialism is no longex in Africa just a popular word behind which hide philosophical ideas about exclusively African values. This time it is the question of the social system. It is significant that the progressive African regimes of today do not speak of a specific "Congolese", "Somalian", or "Mozambiquan" socialism. A serious discussion today about the social and economic development in Africa must take into account and examine these conscious efforts at formulating policies which provide an alternative to the dominating dependence pattern.

But if these countries strive towards the construction of socialism as a rational choice, how should their present development strategies be characterised and evaluated? Many partial questions and answers have been presented in recent research, notably on Tanzania. What are the prospects for self-reliance for a small economy like Tanzania? What is the role of the party, the trade unions, and workers' committees? What is the relationship between the nationalised companies, the parastatals, and foreign capital, particularly in view of various co-operation agreements? What role is assigned in practice to agriculture in the construction of a self-reliant economy? What is the social basis of the state, do the state bureaucrats constitute a class of their own, and do they bear the characteristics of a bourgeoisie? What are the causes and effects of the emergence of a class of 'kulak' farmers in some areas?

While these questions have been probed into by social scientists in Africa itself, and in development research in Western Europe and North America, a theoretical discussion on the larger question of the possibilities of constructing socialism in the Third World without passing through a stage of fullgrown capitalism has developed in the socialist countries of Europe. This by-passing of capitalism has been termed the "non-capitalist path".

There is also a lively discussion on the wider perspectives of the dependence system as a whole. One of the interesting issues here is the question whether new dependence patterns result in new barriers to independent development, barriers which cannot easily be overcome simply by nationalisation measures.

Although the roots of this discussion can be traced back to the Comintern debates in the 1920's on the prospects for a transition to socialism in what then werecalled the Eastern countries, the concept of a non-capitalist path was coined in the late $50^{\prime} \mathrm{s}$ by Soviet social scientists studying the development in Ghana during Kwame Nkrumah's time. Nkrumah's anti-imperialist foreign policy statements, his panAfricanism, and the avowed objective of socialist planning and 
development were seen as the basis for a break with Western models, and the starting-point for a new departure in socio-economic development in Africa. Revolutionary democrats, such as Nkrumah, were seen as capable of bringing the African nations, through appropriate prohibitive measures against foreign capital, and based on a broad alliance of workers, peasants, and the national bourgeoisie, through the stage of a national-democratic revolution as a transitional period to socialism. The strength, example, and assistance of the world socialist community was seen as the crucial factor in opening up this option for the countries of the Third World.

If it is taken as a simple recipe or as the objective necessity for all Third World countries in the face of the obvious difficulties in overcoming underdevelopment by the liberal models, the theory of non-capitalist development becomes an uninteresting piece of wishful thinking. But the necessity to qualify and examine closer the conditions for the alternative development strategy became clear already when the prime example and show-case disappeared with the overthrow of Kwame Nkrumah in 1965. The self-criticism of the theory of a non-capitalist path as the sum-total of specific state policies included observations that there had been no large mass participation of the population in the development efforts, and that Ghana was still dependent on foreign capital. In more recent years increasing attention has been given to the problems of the political aspects of the transitional stage.

The discussion on non-capitalist or socialist-oriented development has involved a great number of social scientists in the USSR, Poland, Hungary, Bulgaria, the German Democratic Republic, Czechoslovakia, Roumania, and Yugoslavia, but has not reached out very far across the borders of the socialist countries, despite the fact that its concerns are of central interest to all involved in formulating and studying the alternative development strategies in Africa.

The idea behind the seminar on non-capitalist development in Helsinki in August 1976 was to bring together people actively engaged in formulating the development strategies in some of the progressive African countries, students of development problems from Scandinavia and other Western countries, and people involved in the formulation and reformulation of the theory of non-capitalist development path from the socialist countries. Unfortunately, we were not entirely successful in our objective. The Africa Institute of the USSR Academy of Sciences, which was to be one of the sponsors of the seminar, together with the Scandinavian Institute of African Studies and the Institute of Development Studies in Helsinki, had to withdraw its participation due to organisational difficulties. Paxticipation from the GDR, Hungary, and 
Poland still made it possible to achieve some of the interchange we had hoped for.

A general introduction to the seminar was given by Joe Slovo, who identified some problems in the theoretical discussion on the transition to socialism in Africa. The obvious priority for progressives in Africa is to work for the completion of the democratic stage of the decolonisation process. But from this premise some incorrect inferences can be drawn. Slovo characterised and took exception from two schools of thought, both of which have as their starting-point the analysis of the state, and not an analysis of the conflicts which is going on between the classes.

The first school Slovo called "the school of false decolonisation", which from time to time has had its protagonists, particularly among expatriate academics working in Africa. According to this school, nothing really fundamental has changed in Africa in its relationship with imperialism. The various state forms are appendices of neocolonialism. The conclusion drawn from this is that what is required in Africa is an immediate struggle under the leadership of the workers and peasants to capture state power and destroy the classes or groups or bureaucratic bourgeoisie, which are in alliance with international imperialism. The deficiencies in this approach, according to slovo, are that it is based on the illusion that there already is a developed proletariat and political forces which can translate this cliche into reality. Also, this view fails to view the present stage of the struggle in Africa in terms of necessary alliances, other than that between workers and peasants.

The opposite approach, of which slovo also was critical, is that taken by some of the advocates of the non-capitalist path. It does correctly view the mobilisation of a broad alliance for the completion of the national-democratic revolution as a primary task. But the way in which certain countries have been dealt with actually excludes from the alliance participation of whatever working class does exist, and does not view it as a problem that independent working class organisation is inhibited. There is a lack of analytical concentration of the conflicts emerging in the state form between emerging class forces. Much of this writing suggests, wrongly, that Africa has the possibility not only to by-pass capitalism, but also to by-pass class struggle. The basic weakness here is that the state is regarded not as the instrument, but as the regulator of class struggle. The state can, and in Africa often does, take on a more or less autonomous character as a mediator between the social classes, but in the end the state objectively reflects a class position. Slovo's word of warning on this point was an 
overdue trust in the capacity of the state administration to carry the development forward, substituting "conspiracy at the top for mass organisation down below".

Another general introduction was given by Jack Woddis. His remarks were actually a comment on a paper written by one of the soviet scholars at the African Institute in Moscow, Gleb Starushenko, which had been distributed in advance of the seminar on recommendation from the expected Soviet participants ("Africa Makes a Choice, Novosti Press Agency, Moscow 1975). Even without the planned dialogue, some of the comments are worth repeating for their general interest. Woddis expressed his basic agreement with the theory of "the non-capitalist path" (although he thought the term itself often added more confusion that clarification), and paid tribute to the absent soviet scholars, who have been working on these questions from many years. The problem of the transition from a democratic to a socialist revolution is common to all countries. But the vital question is the character of the transition.

Here Woddis added some reservations to the way these problems are treated in the paper by starushenko, and in general in the writings on the non-capitalist path. There is, he said, an insufficient treatise of a central question, i.e. the character of the political power required to affect the revolutionary processes and the class character of the state. The transitional period in, for example Vietnam, was relatively short due to the fact that political power was in the hands of the working class and its allies, and the working class was recognised as the leading force. But in Africa this is not the case anywhere. There is a variety of political forms, and sometimes a generalised analysis can exclude a concrete examination.

In his paper starushenko says that "for the newly liberated countries the socialist community fulfills the role of the international proletarian vanguard" (p. 19). This caused Woddis to emphasize that while the role of the socialist community indeed is great, such a statement must not mean that the role of working class leadership could be fulfilled from outside. The people in the developing countries themselves do not play a subordinate position in the revolutionary process, but actually everything will depend on the development of the class forces in each country, influenced as the class struggle is from outside.

The need to develop further the discussion on the conditions for a socialist-oriented development in Africa is well illustrated by the developments in Egypt, as was repeatedly pointed out at the seminar. Egypt was often cited before as an example of a country on a "non- 
capitalist path". Now everybody would agree that it is rather an example of a country taking a clearly capitalist path. The earlier assessment must have been made on too superficial an examination of the development of class forces, and the acceptance of rhetoric for reality. For example, there was a law in Egypt putting down the rule that at least half of all members of elected assemblies had to be workers and peasants. But even the law itself defined "workers" to include managers, and "peasants" to include big farmers and even landlords. The case of Egypt illustrates the need for a parallel examination of the capitalist development in Africa. It was even suggested that "the capitalist path" in Africa should be the subject of another seminar.

If one may try to summarise a four day long seminar filled with intense and lively discussion, perhaps it can be said that there was general agreement on the relevance and need for a theoretical basis for the study and further development of alternative paths of development, but many reservations to simplistic formulae without sufficient concrete research. Hopefully, the publication of this selection of papers from the seminar, and the reports from the four work groups, will stimulate further discussion, research and action. 
Clive Y. Thomas

CLASS STRUGGLE, SOCIAL DEVELOPMENT AND THE THEORY

OF THE NON-CAPITALIST PATH

This paper offers a critical discussion of the theory of non-capitalist development. The first four parts are mainly expository. The effort here is to elucidate the underlining themes. The final part of the paper is devoted to a critique and evaluation.

Marxism-Leninism is the scientific approach to the study of social development. As developed by its principal founders, Marx, Engels and Lenin, scientific socialism is the ideology of the only class which can bring an end to capitalism and initiate the construction of a socialist society transitional to communism. Because of two major determining features, the so-called Third World countries have posed immense problems for both socialist analysis and practice. First, these countries are characterized by the general underdevelopment of their national bourgeoisie. Much of the 'national' wealth is in foreign hands, and a class of native capitalists is only now emerging. Second, the corollary of this is the underdevelopment of their working class - the proletariat. This underdevelopment reflects both the small proportion of national output and employment which is provided by industry, and the predominant roles played by the peasants, landowners, and intermediate strata, in the national economy. Thus the two major classes of capitalist societies are, to varying degrees in each country, in the relatively early stages of their formation.

The theory of the non-capitalist path to socialism is based on the potentialities of the so-called 'national democracies' which are sometimes formed in these countries. Tanzania, Algeria, Congo (Brazzaville), Guinea, Somalia and Mozambique are very good examples. The state of 'national democracy' is considered, both theoretically and operationally, as a state transitional to socialism and the dictatorship of the proletariat. A transition along the lines is called the non-capitalist path, because among other things, there is not the necessity for either the prior establishment of an indigenous capitalism, (before a socialist society can be constructed), or for capitalism to be the inevitable outcome of developments within the 'national democracy'.

\section{Context of development of the concept}

The first documented official reference to the concept of non-capitalist development in the international communist movement is to be found 
in the record of the 1960 World Conference of Communist and workers' parties. Prior to that the concept was mentioned in the general discussion at the Sixth Congress of the Comintern in 1928. However discussion of directly related issues were taken up as early as the second congress of the Comintern in $1920 .{ }^{1}$ It would be useful if we prefaced our discussion by briefly recalling the general context within which this theoretical formulation has emerged.

From the dates given we observe that in the world context, capitalism had already developed to its highest stage of imperialism. Its decline and period of general crisis had already started. This was partly set in train by, and was reflected in, two basic revolutionary streams. One has been the continued rise of the socialist bloc of countries, beginning with the tentative consolidation of the first socialist state in Russia, to the present decisive swing in favour of the forces of socialism. The other has been the national liberation movement which has so far resulted in at least the decisive severing of the links between classical colonialism on the one hand, and capitalism and imperialism on the other. As we have previously indicated, nationally the liberation movement has advanced in countries generally characterized by an underdeveloped working class and bourgeoisie. While this situation reflects their weakly developed levels of indigenous capitalism and the strength of feudal and other pre-capitalist organizations of production and social relations, the weak working class and bourgeoisie have been paralleled by the underdevelopment of the political organizations of these classes. The result has been that the leadership of the national liberation movements are held by strata which have been variously described as 'progressive middle strata', 'revolutionary democrats', 'radical elements of the petty-bourgeoisie' etc. These strata are in turn supported by broad masses of proletarian, semi-proletarian elements, including at times sections of the emerging national bourgeoisie.

At the ideological level, these developments have been reflected by two currents of analysis. First there have been attempts by the pettybourgeois elements to elaborate and synthesize their own ideology. This has usually involved the suppression of class analysis. The assumption was often made that political liberation from colonial rule would more or less automatically and directly lead to economic and social liberation. That it would bring to a halt the processes of class formation, since generally these were initiated by the colonialists, with the precolonial period being a veritable haven of classlessness, and communist, collective social relations. Such ideologies idealize the Third World and gave rise to a bewildering variety of 'national' socialisms. Second, among Marxists-Leninists there have been two tendencies. On the 
'right', there are those who have accepted the situation at face-value and have tended to see these countries as being already as socialist as their leadership declared. While on the 'left' there were those who stressed that a socialist orientation depended exclusively on working class control and direction of social development. Without working class political hegemony only capitalism would develop. Sometimes as critics of this viewpoint allege, this led to the view that these countries had to develop capitalism first in order to generate a workingclass capable of building socialism. There is also, the less frequently recognized 'left' tendency, which argues that capitalism is a world system that has already reached its apogee. Therefore all countries could be considered as rife for socialist construction - although some areas of development and some countries would be more favourably placed than others.

Proponents of the non-capitalist path strongly criticize both these major currents of analysis. The first is considered to be utopian and unscientific, while the second current of analysis with its two tendencies are criticized as 'left' and 'right' deviations of Marxism. Theoretically and operationally the non-capitalist path was advanced as an approach which avoided these fundamental weaknesses. It therefore embraced certain clear and explicit objectives, viz,

i) to creatively develop Marxism in order to provide an understanding of the present objective and subjective possibilities for working class advance on a world scale, without committing the obvious errors of 'right' or 'left' deviations.

ii) to recognize the vast variety of circumstances in individual countries and regions, but yet to conceptualize both the individual variations and the regularities to be found in these societies at the immediate post-colonial stage.

iii) to advance theory in a non-dogmatic manner and therefore to see this approach as one possible path from the national liberation movement to socialist construction.

Given the context in which the non-capitalist thesis was formulated and the range of phenomena it sought to embrace, it is not surprising to find that in the literature, the historical experiences of Africa and to a lesser extent Asia are those mainly considered, with only limited reference to Latin America in confirming the real possibilities of such a path to socialism. For the period prior to World War II, it is only the 'backward' territories of the USSR and the Mongolian people's republic which are given as examples of the use of the non-capitalist path. But because of correct criticisms that the degree of geographical proximity of Mongolia to the USSR, and the fact that developments with- 
in the national context of a society already transitional to socialism, are not directly comparable to the situation today, these pre-war experiences are infrequently alluded to. The references are mainly to Afri$\mathrm{ca}$, both because as a whole the African working class is the least developed, and also because most of the decolonization process on this continent has been highly compressed within the years since World war II. The result has been that this concept has become highly identified with Africa, creating at times the wrong impression that it is the African path to socialism.

\section{Major Theoretical Issues}

Classes and Class Formation. The already indicated underdevelopment of the working class in the Third World countries, immediately raises the question, can this class and its party play the vanguard role in the entire movement from national liberation to socialism? While all Marxist observers would agree that socialism cannot be constructed without working class direction of the process and under the leadership of a working class party, there is disagreement as to whether after political independence is won working class political control is essential to further the revolutionary advance. Advocates of the non-capitalist path argue that this is not necessary. Indeed, they point out that attempts to prematurely assert working class leadership would split the progressive forces, weaken the working class, and open up the possibility of counter-revolutionary developments. In this context a non-capitalist approach based on a broad alliance of progressive forces offers the best overall revolutionary prospect. It is important to note that while all supporters of the non-capitalist path stress that this path is 'one possible path', in practice the argument is so advanced that it is frequently projected as the best, if not the only realistic path to socialism. The result has been to generate a considerable degree of confusion.

Marxists recognize the need for alliances in the working class struggle. The non-capitalist theory bases itself on this. But while it advances the pivotal class structure to be the alliance between workers and peasants, it sees a much broader alliance as operationally necessary. This broad alliance would include not only the usual middle strata, radical sections of the intelligentsia, students, the rural and urban petty bourgeoisie, but at times sections of the bourgeoisie itself. As we shall see later this is one of the most contentious and badly formed of the theoretical and political underpinnings of the theory of non-capitalist development. 
The class alliances referred to reflect a political compromise. At the ideological level there is and indeed can be no compromise. Any such compromise would certainly result in class collaboration. Communists are therefore expected to struggle to maintain the purity of MarxismLeninism. As we shall stress later, in so far as political compromise has often been interpreted by the ruling petty bourgeoisie to embrace the right to repress communists and communist activity, it is very difficult for ideological purity to be sustained and indeed for MarxismLeninism to be carried to the masses of the working people. In this regard we should have no illusions about what political compromise involves and hence the pressures under which the working class and its parties would have to operate. As Lenin pointed out:

the entire history of Bolshevism both before and after the october revolution is full of instances of changes of tack, conciliatory tactics, and compromises with other parties, including bourgeois parties. To carry on a war for the overthrow of the international bourgeoisie, a war which is a hundred times more difficult, protracted and complex than the most stubborn of ordinary wars between states, and to renounce in advance any change of tack, or any utilization of a conflict of interests (even temporary) among ones enemies, or any conciliation or compromise with possible allies (even if they are temporary, unstable, vacillating or conditional allies) - is that not ridiculous in the extreme? Is it not like making a difficult ascent of an unexplored and hitherto inaccessible mountain, and refusing in advance ever to move in zig-zags, ever to retrace one's steps, or ever to abandon a course once selected, and to try others? 2

As leadership along the non-capitalist path is usually provided by the revolutionary democrats or progressive elements of the petty-bourgeoisie, it is important, therefore that certain features of these strata are immediately indicated First, since they are not clearly dependent on either majox class political organization they tend to rely heavily on the military - administrative apparatus. This as we shall see later constitutes a severe weakness of the state, for this dependence undermines working class political expression and development. Second, like all petty-bourgeois elements there is a tendency to vacillate and to act uncertainly. This is readily conceded by the staunchest supporters of the non-capitalist thesis. "Vacillation, change of heart and fence sitting as between the working people and the bourgeoisie are the mark of the petty-bourgeois intellectual." 3 Third, this posture dovetails into the 'mediating' role this class can play, on account of the underdeveloped state of the two major classes. The possibilities of mediating between these classes are of course directly supported by their control of the state apparatus. The result of all this is to create among these strata illusions of a supra-class character and a feeling that they alone can, and do, represent the interests of the "whole nation". Given the relative stability of this 
group, brought about by the slow development of the major classes, it is expected that it would endure for some considerable time. The fourth feature we have already alluded to, and it is that the ideology of this group develops with a strong admixture of non-class ideas and nationalism. Invariably this is strengthened by the prevalence of religious views, the latest fads in bourgeois ideology and Marxist-Leninist slogans.

Despite the above indicated features, proponents of the non-capitalist thesis argue that objective circumstances will drive these strata closer to Marxist-Leninist positions. Whilst this has clearly been evidenced in individual outstanding cases, e.g., Nyerere, Nkrumah, Cabral, etc, there is no real evidence so far that the mass of these parties have moved in any such direction. Yet, unless this occurs, the borderlines between political compromise and ideological compromise, class collaboration and class struggle, will remain blurred and confused to those struggling locally.

The internal class alliances in the non-capitalist societies can fortify the national liberation movement if it succeeds in encouraging progressive elements to work together. If this occurs it would contribute greatly towards forging a unity of the world's three major revolutionary currents: the socialist societies, the working class movement, and the national liberation movement itself.

The nature of the state. It is clear that with the major classes underdeveloped, the state itself will also be an underdeveloped institution. In addition, in the non-capitalist society the state is dominated by the petty-bourgeois elements. These two circumstances contribute to giving the state the appearance of being 'independent' and 'autonomous' if not indeed a supra-class, institution. But, because the state does not reflect the clear domination of one social class over all others, control of the state itself becomes remarkably susceptible to narrow shifts in alliances among the ruling petty-bourgeois elements. The coups and counter-coups which have prevailed in many of these countries reflect little more than shifts of power and position among the pettybourgeois elements.

That the 'independence' and 'autonomy' of the state is an illusion is often not perceived as such among the leadership of the non-capitalist states. This is not altogether unexpected since the objective position of the petty-bourgeoisie in these countries is that they do consitute a confused social stratum. Frequently, even the most progressive among them act as if the state is neutral, set themselves up as arbiters between the working people and the bourgeoisie (local and foreign), 
and propangandize to the effect that they, and only they, represent interests that are national and therefore beyond all sections and classes. From here it is but a short step to systematically relying on the armed forces to police on their, or the nation's behalf, and so rationalize the creation of one-party regimes.

The real consequence of all these developments is that the state cannot be viewed as merely the object of class conquest, but in the circumstances as the principal instrument of class creation itself:

"Traditionally, in the context of highly developed class societies, socialist analysis correctly interprets the state apparatus as the object of class conquest and the instrument of class rule. In the historical situation that prevails in these countries, it is more correct to argue that the state has become, as it were, an instrument of class creation. This observation highlights the crucial difficulties which are posed for socialist analysis of the state by the existence in these societies of what is often only a very immature industrial working force, and an underdeveloped local bourgeoisie. This results in at least two very important dimensions being attached to the 'instrumentality' of the state. One is, of course, its well known instability and easy susceptibility to even very narrow changes in alignments among the petty-bourgeois elements which presently dominate the state machinery. The other is its illusory appearance of being independent (i.e., in effect 'beyond class') both vis-a-vis the international capitalist order and local class formations." 4

The weak nature of the national bourgeoisie favours a certain type of expansion of the state sector. In many of the non-capitalist societies, nationalization of foreign enterprises has developed progressively and fairly rapidly. The national bourgeoisie in these countries have frequently not resisted nationalist interventions against foreign capital or those in support of small and medium indigenous capital. This type of expansion of the state sector does not contradict the fact that the state can and does remain oriented towards capitalist relations. The principal objective of state action is to support and implement the anti-feudal and anti-imperialist thrust of the revolutionary front. In this regard the state has no imperative to act against the interests of the emerging national bourgeoisie.

"In the first place, at this particular stage the national democrats upholding the non-capitalist path of development are coming to grips with tasks of an anti-feudal, anti-imperialist nature, i.e. general democratic tasks the implementation of which is also in the interests of a certain section of the national bourgeoisie. Egypt's charter of National Action makes this quite clear since it contrasts national capital, that is included in the category 'working forces of the people,' and exploiter capital." 5

Because the tasks of the state are limited to those of an antifeudal, anti-imperialist character we can readily see why it is not necessary to have a Marxist vanguard party in control during the noncapitalist phase, for all these tasks accord with the general interests of the emerging exploiter classes. 
The experience of poverty. The underdevelopment of the major classes, together with the marked dependence of the Third World countries on the imperialist system of trade, investment, and aid, corresponds to the pervasiveness of poverty and exploitation in these countries. To proponents of the non-capitalist thesis.these circumstances under which social life prevails constitute the objective conditions which propel the national democrats in a revolutionary, anti-imperialist and even socialist oriented direction. In the ideology of this group, economic independence is a sine qua non for social development, and foreign capital is seen as both the cause of poverty and the basis of continued national exploitation. The development of an aggressive stance towards foreign capital is reflected in the large-scale nationalizations which have occurred. Apart from Marxists, it is only among very few elements of the political structure that all capital is seen as exploiting, and nationalization without worker control is recognized as insufficient to ensure real social development. Generally these attitudes confirm to the growing recognition that the contemporary bourgeoisie is no longer a progressive social force - as they were in the early ascendant days of capitalism.

It is difficult to deny that these conditions of poverty and exploitation generate strong nationalist sentiments and contribute to an anti-imperialist world outlook. Unfortunately this alone cannot be enough, for the struggle against foreign capital has to be viewed in the context of internal class development and the role of national capital in social life. Proponents of the non-capitalist thesis have not always articulated these links very clearly. One reason might in fact be the relative dearth of research in these countries, in these areas. What the proponents do correctly recognize however, is that the constellation of social circumstances (including the size of many of these countries) deny them any real choice between socialism and capitalist development. Capitalist development has in no instance advanced beyond the dependent type industrialization of the Latin American economies. The only way forward is the socialist way, and this objective truth has no doubt operated as a powerful lever in the direction of social development and class truggle in these countries.

Productive Forces and Production Relations. On the broader theoretical front two further issues are raised by the non-capitalist thesis. The first is the method or stages of transition to socialism, and the second is the relationship of the level of development of productive forces to the social relations of production in the development and transformation of a given mode of production. The non-capitalist thesis 
clearly suggests two definite stages of development for the recent excolonial territories as contrasted with the advanced capitalist societies. In the latter there is the general phase of the transition to socialism, while in the former this is preceded by a phase of non-capitalist or national democratic development. The non-capitalist path clearly indicates the by-passing of capitalist development. This is in conformity with the Marxian laws of successive social formations. The existence of a world system of socialist societies means that a higher social order than capitalism already exists. In this circumstance each and every society, each and every people do not have to follow the identical path of evolution, to the already existing higher social order on a world scale.

It is apposite to recall here that when these issues were discussed at the Second Congress of the Comintern in 1920, many delegates were optimistic about the spread of successful social revolution in Europe. If this had occurred it would have decisively swung the balance of forces in favour of socialism at an early date. It was felt that in this context the already developed social forces of socialism would have facilitated many societies going over to socialism without having to go through long periods of capitalist development. At the 1920 Meeting Lenin posed the issue as follows:

"Are we to consider as correct the assertion that the capitalist stage of development is inevitable for backward nations now on the road to emancipation and among whom a certain advance towards progress is to be seen since the war? We replied in the negative ... With the aid of the proletariat of the advanced countries, backward countries can go over to the Soviet system and, through certain stages of development, to communism, without having to pass through the capitalist stage," 6

While rejecting the necessity for capitalist development, the noncapitalist thesis is not altogether very clear about the nature of social relations of production during the non-capitalist phase. It would seem reasonable to conclude that the non-capitalist path does not involve any qualitative shift in these. Certain characteristics of social relations may change, for example the rise of state property, but whether these are built on the foundations of capitalist or socialist relations can only be determined after study of the position of the various social classes. In so far, however, that the working class is not dominant and so cannot direct social development, chanjes in social relations can only be confined to the elimination of feudal and pre-capitalist survivals, along with the restriction of foreign property. There can be no qualitative changes in the indigenous capitalist relations themselves. Any other conclusion would degenerate the non-capi- 
talist thesis to a "third way". But such a methodological approach has been universally condemned by Marxist supporters and opponents of the non-capitalist thesis alike.

One of the further difficulties which we are faced with is that a study of the experiences of these countries indicate that even the more 'mobile' elements of the social mode of production, i.e. the productive forces, have so far failed to indicate any significant changes in either their levels or character. The presumption therefore is that the noncapitalist path can proceed for some considerable time, since all indications are that the social relations of production do correspond to the level of productive forces as they are developing and the superstructural changes, particularly the state and political organisations have failed in this context to produce any real 'lag' in these two dialectically related aspects of the mode of production. Such a conclusion is not based on any particularly harsh criticism of the petty bourgeois strata, although in another context I have for example urged that:

"For the small neo-colonial economy, the result of the present conjuncture of production relations and productive forces is to create an economic structure in which the carry over from the overseas sale of its domestic production is minimal ... This does not mean - as it does in the radical literature where this feature is frequently exaggerated - that it is correct to argue that there is no 'carry-over' ... there is indeed but what is truly significant is that the carry-over is often substantial, relative to the surplus needed to satisfy those domestic social classes which benefit from this dependent structure."7

\section{Character and Tasks of the Non-capitalist Society}

At this point it would be useful if we were to sumarize very briefly the main character and major tasks of non-capitalist development, under favourable circumstances. First, since in general it is conceded that capital development does guarantee the maturation of social and material conditions to the point where socialism can be constructed, then in the absence of this, this prospect can only exist if specific internal and external factors combine. Second, the major external considerations are a swing in favour of the forces of socialism, particularly as manifested in the growing strength of the socialist bloc of countries, and the threatened collapse of capitalism and imperialism on a world scale. Third, internal factors must ensure a broad alliance of 'progressive' forces. This alliance would include elements of the emerging national bourgeoisie and would be the main factor in directing political development. An alliance of the peasantry and the working class however, forms the real foundation on which political and social struggle is built. Fourth, such an alliance rules out the necessity of either 
working class direction of social development or that political power and the state machine should be under the control of a working class vanguard party. It is enough if the progressive sections of the petty bourgeoisie rule. Fifth, the state remains underdeveloped with all the accompanying weaknesses. This underdevelopment reflects the underdevelopment reflects the underdevelopment of the major classes and their corresponding political organizations, and is reflected in petty-bourgeois domination of the state machinery.

Sixth, in light of all these characteristics, certain priority tasks of an anti-feudal, anti-imperialist and national democratic character are to be pursued. Among these are:

i) an end to all foreign monopolies in the national economy

ii) the implementation of a program of agrarian reform and the elimination of all forms of rural exploitation

iii) struggle against domestic monopoly and domestic forms of exploitation

iv) the development of a planning machinery to pursue the tasks of building a national industrial structure and a diversified agriculture

v) the consolidation of national sovereignty and national independence by bringing to an end all foreign bases and alliances

vi) to pursue an independent foreign policy and particularly one in support of national liberation and against imperialism

vii) to democratize all aspects of social 1 ife and to resolutely fight against all dictatorial and anti-popular methods of government

These tasks are not seen as simply 'policies,' but are advanced as 'objective' requirements of the social order. They are aimed at the elimination of pre-capitalist relations and an orientation of all social groups against imperialism and hopefully for socialism and against capitalism as well.

\section{Criticism and Evaluation}

The advocates of the non-capitalist thesis claim to be making a theoretical advance based on certain historical tendencies, as well as to be describing historical actuality as it has emerged since the end of World War II. Actual historical experience therefore serves a double role in an evaluation of this theory. There can be little doubt that the theoretical formulations of the non-capitalist path are a real advance on both bourgeois analysis of the post-colonial situations, and 
some of the more fashionable 'right' and 'left' tendencies indicated earlier. Equally well, however, there can be little doubt also that many of the theoretical formulations as they stand, are to say the least, vague and unsatisfactory in a number of important ways. The most important of these are the analysis of class, and the relationship of political democracy to political life in the non-capitalist society. In this section I shall offer some comments under these two headings and then conclude with a few general observations on some other related themes.

Class. Despite the imposing list of characteristics and the tasks required to be pursued by the non-capitalist society, in practice, when studying the development of these societies, a great deal of over-emphasis has been placed on the anti-imperialist posture of the state. This is usually measured by the extent to which a progressive foreign policy is being pursued and the pace of nationalization of foreign monopolies. The corollary of this over-emphasis is the considerable underplaying of internal class struggles. The implication which seems to be luxking below the surface is that if the major classes are underdeveloped, so must be the level and intensity of the class struggle! But this of course would be an absurd deduction. In practice it has also been generally found, that apart from the issues to be discussed below concerning the role of 'alliances', little attention is paid to the possible intensification of imperialist efforts to win class allies within these countries, and hence the external impetus to heightened internal class struggles. One of the major reasons for this situation is that when classes are newly emerging their lines of conflict are not always readily perceived. The observations made here do not gainsay the theoretical and practical validity of alliances in the course of the working people's struggles. While the Marxist thesis of alliance is perfectly acceptable in principle, in practice it is the class elements of any given alliance which determine its relevance to the working class struggle. This relevance cannot be established through abstract adherence to the necessity of alliances. In this regard we must therefore pay close attention to the class character of the petty-bourgeoise and the big bourgeoise in our analysis of non-capitalist development, for the worker-peasant alliance raises no real difficulties of strategic relevance.

The petty-bourgeoisie is important in these societies because of their monopolization of the state in all its major areas of functioning 
(administration, justice, security, political decision-making, lawmaking, planning, etc). Experience has shown that while elements of this stratum have the same broad social origins, yet they take widely divergent positions in the workers' struggles. This vacillation is compounded by tendencies referred to earlier for this social group to see themselves as arbiters and the only real representative of national interests. To this stratum, rarely do national interests app $a$ ar to be in contradiction with the development of national capital, and as a consequence within these societies this stratum is generally becoming stratified and the military - bureaucratic elements are emerging as the main factors in capitalist development. They use the state and its command over the people's resources to accumulate on their own behalf, and certain areas of national capital, e.g., construction, trade, food production for the urban sector, and partnership with the local expression of the multi-national firm etc., become their automatic preserve.

Al1 these developments are rationalized by the need to overcome backwardness and to produce more. In this context it is only foreign capital that is portrayed as the enemy of the emerging working class. But nationalization of foreign property, while objectively it is a social advance, it can not lead automatically to the improvement of working class positions. To bring this about, struggles by the working class and its party have to be pursued. But not infrequently we find that the alliance rules out the independent development of working class institutions and cuts off the access of working people to political and social power! Indeed in many of these countries the Trade Unions have been brought directly under the wings of the petty-bourgioisie, and the strike weapon has been removed under the guise of maintaining national production. However, as stratification of the petty-bourgeois elements proceeds, increasingly the military-bureaucratic elements rise to the fore and the whole issue of class struggle becomes intimately connected to the issue of political democracy.

As the petty-bourgeoisie becomes more stratified, capitalist elements among them merge with the incipient capitalist class and landowners. Often this is accompanied by a sharp deceleration of land-reform measures and increasing bureaucratic protection of, and permission for, indigenous private accumulation to proceed. When this is combined with increasing tendencies to contain overt Marxist activity among the working people, the expansion of capitalist elements within the alliance makes it tenuous, indeed. Here the experience of Latin America, and chile in particular, are relevant. 
A close study of the Chilean experience suggests, inter alia, that:

i) if the Marxist elements remain a minority in a national government, or constitute a minority government themselves, then the prospect of a developing socialist orientation within the society is significantly different from that of a majority position with effective control of the legislature judiciary and executive arms of the state. This suggests that a workers' party in effective control is a crucial factor in ensuring the transition from national liberation to socialism. The same experience is afforded by the cuban example as well as those of Vietnam and North Korea in Asia.

ii) the ability to pursue non-capitalist tasks is heavily contingent on the ability to cope with economic sabotage and other dimensions of 'destabilization' as counter-revolutionary activities. This places a heavy premium on economic organization, management and strategy. Areas, where to say the least, virtually no sustained analysis has been undertaken by Marxists.

iii) elements of the national bourgeoisie cannot be relied upon beyond an anti-fascist front. Experience suggests that even a minimum working class - anti-imperialist programe would alienate them. This experience combines with other noted tendencies for these elements to desert the alliance, as the economic situation improves and national life develops.

iv) finally, despite their highly visible roles, the analysis of the military in these countries still remains very unsatisfactory.

Conclusions from the above three major propositions are the following. The first is, that it is the scope for independent development of working class institutions and working class power that is the most crucial factor in non-capitalist development. Unless this receives primary consideration internal development would not be accorded the leading role. Second, "while focusing on nationalization and foreign policy postures it is easy to overlook what ... Fanon has referred to as the 'pitfalls of national consciousness'. Where ... revolutionary rhetoric has frequently been used as a substitute for revolutionary practice and where the state functions by seeking to concentrate more and more power in the hands of the ruling section of the petty bourgeoisie, by eschewing democratic practice and ruling through the means of political repression, victimisation and the limitation of political expression and participation in national life ... and by manipulating racial and/or tribal divisions among the people in order to consolidate their rule." ${ }^{8}$ The third proposition is that insufficient theoretical and practical attention has been paid to the need to democratize 
all aspects of social life and to fight against anti-popular methods of government as a condition of the pursuit of non-capitalist development. "In some countries new economic, social and political conflicts emerge within the framework of essentially capitalist development, which leads to differentiation among the revolutionary democrats themselves. In particular, some segments evolve towards conservative or even reactionary bourgeois positions. Given a monopoly of power and ideological activity, these processes sometimes result in tendencies to restrict or bar the activities of other progressive social and political forces, to restrict the political movement of the masses, especially the working class." 9

As history has repeatedly shown attacks on the working class do not strengthen the state. To the contrary, it weakens it, because they serve to demobilize the working people. The experience of Ghana and Indonesia are there for all to observe. In view of this it is difficult, and perhaps impossible to envisage that these "fronts" can build, except in extremely unique circumstances, either a workers' party, or permit one to emerge.

Political Democracy and the Non-Capitalist Way ${ }^{10}$

Regrettably, an unfortunate attitude has grown, (which is not supported by Marxist-Leninist theory), of counterposing socialism and political democracy and by extension, non-capitalist development and political democracy. This attitude is based on the argument that socialism does not require political democracy. As this argument goes, political democracy is a bourgeois illusion, based on so-called bourgeois freedoms, which are simply a mask on the system of economic domination of the workers in capitalist societies. It is suggested, therefore, that political democracy can have no place in a socialist society. This attitude, and the arguments produced in support of it, have been used in recent times in all corners of the globe to justify repression and tyranny on an unprecedented scale. The basis of this attitude lies either in an elementary misunderstanding of the notion dictatorship of the proletariat, or deliberate distortion of Marxism. Anyone who has read Marx must know that the concept "dictatorship of the proletariat" which has so often been bandied about recently, refers to the sociological domination of the working class. This domination does not mean any such trite and superficial political notion as authoritarian and tyrannical government. The sociological domination of the working class is expressed in its domination over the means of production and its direction of the labour 
process. It is also, to the contrary of this belief, to be expressed in the development of genuine democracy. Marxist theory has always been explicitly based on the creative interaction of socialism and political democracy .

As Lenin has made very clear "representative institutions remain ... without representative institutions we cannot imagine democracy, not even proletarian democracy."1l Referring to freedom Rose Luxemburg in 1918 pointed out: "freedom only for the supporters of the government, only for the members of one party - however numerous they may be - is no freedom at all. Freedom is always and exclusively freedom for the one who thinks differently. Not because of any fanatical concept of "justice" but because all that is instructive, wholesome and purifying in political freedom depends on this essential characteristic."12 or to quote Lenin again: "it follows that proletarian dictatorship must inevitably entail not only a change in democratic forms and institutions, generally speaking, but precisely such a change as to provide an unparalleled extension of the actual enjoyment of democracy by those oppressed by capitalism - the toiling masses."13

What are these freedoms which are termed bourgeois, and there-after declared to be luxuries in order to justify trampling upon them and abusing them? In general they include a number of individual and collective rights, viz, freedom of speech and expression, freedom of association, freedom of publication, the democratisation of political life and the electoral system, the independence of the judiciary, the rights to privacy, the insistence that institutions be representative of the popular will and so on. A mere glance at this list of so-called bourgeois freedoms show that to the extent they do exist, or have existed, they have all been won on the basis of mass struggle. It was the masses' struggles which demolished the colonial state. It was the masses' struggles which led the way in the fight for representative political institutions. It was the workers who fought for the rights to form workers organisations. Whose knowledge of history can be so slight as to deny that these freedoms are far from being simply bourgeois? That in fact they have been won on the basis of the people's blood! No serious understanding of history can ever show that the advance of political democracy and the obtaining of individual and collective freedoms, have been the product of bourgeois generosity. The workers have won, through struggle, every limited democratic right they have ever had. And so it will always be. 
Political democracy and freedoms therefore cannot be put to stand counterposed to socialism, or to non-capitalist development. Any such argument, or line of thinking is fundamentally anti-Marxist. Rationalizations of the need to curb freedoms in order to further so-called progress have no place in the building of a socialist society. On the contrary, socialist theory advances two fundamental axguments in direct opposition to this view. In the first instance, socialist theory argues that the weakness of freedom and political democracy as it has developed in these societies is not that it is too much, and therefore should be curtailed, but that it is in fact too little. It is too little, not simply because the range of such freedoms is narrow, (which it undoubtedly is), but also because history has shown that without socialism, political democracy and freedom are limited by two important considerations. The first consideration is that the workers (no matter what partial gains they might have obtained in this area), cannot fundamentally alter their position as proletarians on this basis alone. To achieve this they have to gain control of the means of production. They must be able to direct and control the production or labouring process. Unless they do so, they cannot direct the social development of society. The second consideration is that until the workers have this kind of control, political democracy and freedom remain insecure. Experience has shown, beginning with the Soviet revolution, and continuing right down to chile, that if the capitalists and imperialists believe that their class domination is threatened because of a growing political awareness among the working class, they will not hesitate to demolish freedom and political democracy and maintain capitalist rule by tyranny.

The second main argument of socialist theory is that political democracy cannot be discussed as an abstract or pure notion. To be meaningful, it has to be related to the nature of the social system. When therefore we refer to the nature of the social system it will be seen that democracy and freedom constitute an integrated system of economic democracy, i.e. freedom from the tyranny of capital and alien domination of the labour and production process. Therefore, the task of noncapitalist development is to expand the areas of social justice. It can only do this by first of all consolidating existing freedoms. This can only be achieved through the struggle against all forms of domination and the progressive creation of social equality in the status of labour. Simultaneously, as a pre-condition for socialist construction it requires the expansion of freedoms in three major areas:

i) in the wider participation of the masses in administration, defence, public order, justice, i.e., the implementation of practical 
democracy at every level of government.

ii) through providing guarantees to every citizen, irrespective of party membership, of the right to a job, education, health, leisure, and participation in the control of the means of production.

iii) by systematically encouraging and promoting the expansion and development of the political culture. It can do this, not by emphasizing "deals," but by way of the promotion of representative institutions. In this regard struggle along the non-capitalist way must attach paramount importance to the consolidation and development of trade union and party democracy. To socialists, all democratic rights are rights of the people. They are the people's rights because they have been won by the people. They can never be considered as the unilateral concession of the state to the people, and therefore to be removed by the state as and when it believes persons are not toeing the line.

A number of points emerge from our analysis. One is that non-capitalist development, and a fortiori, socialism cannot be built without political democracy. The task is to expand freedom and political democracy by solving the problems of the economic conditions of exploitation which confront the workers. Indeed, socialist oriented development requires political democracy and freedom. The logical consequence of this observation is that to the extent that democratic practices are not being promoted, then the tasks of socialist construction are also not being attempted.

"The experience of the October and subsequent victorious revolutions shows that a multi-party political system does not run counter to the interests of socialism if it helps to bring the masses into the work of building the new society, and if it is directed by the Marxist-Leninist working class vanguard. Marxists-Leninists do not question the validity of a multi-party system as a form of socialist democracy. But they are always guided by class interests in discussing its practical application in one or another country.:13

As we have outlined it therefore socialism seeks to do more than formally proclaim rights. We are building something else, certainly not socialism if the principal objective during the non-capitalist phase is not the creation of the conditions for the realisation of these rights. Unless this objective is tackled from the outset we are not engaged in preparing the way for socialist construction, but simply the rationalization of political tyranny.

In conclusion of this point therefore, we argue that not only is the state of the class struggle primary, but that struggle itself is inseparable from the general conditions for working class democracy and participation in national life. Proponents of the non-capitalist way do 
not often seem to lay enough emphasis on the primacy of mass action in any socialist oriented alliance. This point we feel holds all the more strongly in so far as effective leadership does not lie among the working-class. It is therefore not enough to simply recognize the need for democratic life and pass this over with a general endorsement of the 'progressive' character of these regimes, as ulyanovsky does. The following excerpt indicates this sort of attitude:

"When stating that national democracy answers the aspirations of the popular masses, including the peasants and workers, we mean that the overall policy of these regimes and the progressive socio-economic transformations they implement are in tune with the class and national interests of the working people. As for their real participation in the exercise of state power, as a rule this participation is blatantly inadequate and in some countries even negligible. Military officials and civil servants, the petty-bourgeois intelligentsia and representatives of the liberal professions act as spokesmen of the interests of the - working people within the state apparatus and its economic bodies. Many of these groups in the light of their class background are subject to political vacillations and are often likely to cooperate with private capital. The vital need to draw the working people into active political life and the importance of a reconstruction of the state and party apparatus according to genuinely democratic principles and in such a way as to ensure the wide involvement of workers and peasants is recognised by many leaders of national-democratic regimes. However in the majority of countries that have embarked on the path of non-capitalist development decisive steps in this direction still have to be taken. "I5

Concluding remarks. In concluding our discussion we can note that our examination of the path of non-capitalist development has revealed many differences between the progressive posture of the state and the position of the working class within these societies. A close study of the post-colonial situation shows that there are neither 'state' nor 'national interests' which are not subject to class analysis and interpretation. Until the working class has achieved its historic mission of abolishing all classes, and the state as well, genuine differences will always develop between the interests of the various classes and those of the state. From the standpoint of the working class this conflict is going to be greater, the further they are removed fxom being the dominant class. But, even in societies in "transition to socialism" where working class hegemony is clearly established, until all classes have been fully abolished, genuine conflicts will develop between state interests and those of proletarian internationalism.

It is therefore important to consider to what extent within the socialist bloc, the non-capitalist way might not be more consistent with state interests than it is with those of the working class of these societies. This point is similar to that made when we observed similar 
conflicts in the earlier discussions of non-capitalist societies. Unfortunately this issue has also not been fully discussed and integrated into a Marxist framework. To this extent, therefore the dialectical relationship between developments within the socialist bloc and the noncapitalist societies have not been adequately treated.

Similarly the literature has not considered in anything like enough detail the conceptualization of an economic strategy consistent with the development of socialism in these societies. This is so particularIy when we note that most of these societies are small and the classic modes of socialist industrialization and agricultural development, based on the soviet model, inevitably would encounter serious scale and resource problems. My own study referred to earlier (Dependence and Transformation, 1974, see note 5) is still the only attempt I know of to undertake such a task. It is therefore not altogether surprising to observe how closely economic strategy in the non-capitalist societies follow the classic colonial lines of primary export specialization on the basis of natural endowments, and import-substituting industrialization proceeding from the substitution of final products with the hope of inducing a backward expansion into the capital goods sector. space does not permit me to go into these issues here, but the absence of such theoretical work partly explains why most non-capitalist societies are suffering from problems of expanding real output at an adequate rate. This failure to grow along traditional lines, or to transform the economic structure, generates a number of contradictions in state policy. One of particular note is the contradiction between supporting the market mechanisms to stimulate production and expanding the areas of state property. As a result the reluctance to deal with national capital in a progressive socialist oriented way is rationalized on the basis of fears of the likely inefficiencies in production this will cause along with the disruption of local supplies and shortages.

\section{NOTES}

1. See, J. Slovo, in Discussion Contributions on: A Critical Appraisal of the Non-Capitalist Path and the National Democratic State in Africa, Marxism Today, June 1974.

2. V.I. Lenin, "Left Wing Communism, an Infantile Disorder", in Se lected Works, Vol III, Moscow, 1971, p. 389.

3. R. Ulanovsky, "Some Aspects of the Non Capitalist Way for Asian and African Countries," World Marxist Review, Sept. 1969.

4. Clive Thomas, Dependence and Transformation: The Economics of the Transition to Socialism, Monthly Review Press, New York, 1974, p.87. 
5. R. Ulyanovsky, Socialism and the Newly Independent Nations, Progress publishers, Moscow 1974, p. 78 .

6. V.I. Lenin, "The Second Congress of the Communist International" Collected Works, Vo1 31, p. 244.

7. Clive Thomas, op. cit, p. 54.

8. Clive Thomas, "Bread and Justice: The Struggle for Socialism in Guyana", (forthcoming) Monthly Review.

9. G. Batal's Comment at the International Symposium on "Communists in the struggle for the Unity of Democratic and Anti-Imperialist Forces" published in Peace, Freedom and Socialism, Vol 18, No. 8, August 1975, p. 28 .

10. This section draws on my paper cited in Note 8.

11. V. Lenin, State and Revolution, p. 41

12. R, Luxemburg, The Russian Revolution, p. 69.

13. V. Lenin, Selected Works, Vol 3, p. 156.

14. K.I. Zaradov, in his summary comments in the work cited in Note 9.

15. R. Ulyanovsky, op. cit, p. 81 (emphasis mine). 
Lionel Cliffe

A NON-REVOLUTIONARY TRANSITION TO SOCIALISM?

Adherence to either of the two following propositions would foreclose any discussion of "noncapitalist development: on a priori grounds:

1. The deterministic view that all societies are predestined to go through identical historical stages, or the variant that socialist revolution has to await a certain high level of development of the productive forces and the emergence of a powerful proletariat.

2. The assertion that as all underdeveloped countries are integrated into the international capitalist system and to that extent subject to the operation of its law of value, then they must all be labelled "capitalist" and that any quantitative differerences between more or less "progressive" states is of such marginal significance that they do not imply different prospects for transition.

If, however, some entry into the transitional process prior to the full development of capitalist production is at least admitted as a possibility then debate on the theses of non-capitalist development becomes possible. Some analysts would clearly also recognise the need to conceptualise the distinction between what are inadequately referred to as "progressive" states in Africa, which can be important for political purposes. On these bases, the usefulness of the concept of the noncapitalist path in understanding one type of peripheral capitalist state and the options open to them can be critically assessed. But before coming to such an assessment of the formulations, it may be instructive to review briefly some of the African experiences in a comparative way.

\section{The emergence of "progressive" African states}

A number of examples are cited of states that are or have been categorised as "progressive". It has been pointed out that all too often such a categorisation has been awarded solely on the basis of an anti-imperiam list stance in the foreign policy field. The Iine-up of African states at the beginning of 1976 in support of the MPLA Government was used as a Iitmus test by some observers. All too often, however, such assessments are made with a minimum of reference to internal social conditions in these states.

If a more informed categorisation is made, taking into account some internal variables, care has to be taken not to confuse rhetoric with 
performance, for as many regimes espouse "socialism" as claim to be anti-imperialist, in their public pronouncements. Bearing in mind these cautions, the following countries have al1 at some time attempted programmes aimed at gaining greater public control of their national resources as well as proclaiming some adherence to "socialism: "Egypt, Ghana, Guinea, Mali, Algeria, Tanzania, Somalia.

Some might suggest that Ethiopia, Nigeria and Malagasy, after their recent military coups might be added to this list. And clearly to judge from the programmes of their ruling movements, Angola and Mozambique are likely in the future to attempt their own alternatives to neocolonialism.

Despite many specific differences in their development strategies these states have all attempted to follow what two recent analysts have termed the "traditional strategy for national independence and development." 1 This they designate as a tripartite strategy of nationalization, industrialization, and national planning.

Their arguments as to the inadequacy of this kind of strategy in a world system no longer characterised by the colonial division of labour, of industrialised 'centres' drawing on and in turn supplying raw-material producing peripheries, is instructive in indicating the limits of this strategy and why it does not lead to an actual transition to a socialist mode of production. However, before exploring the reasons for such shortcomings it is worth further elaborating these cases in order not only to detail the content of the strategies but to see if comparison reveals any objective social conditions which give rise to these exceptions to the general rule in post-independence Africa of "neocolonies, par excelilence."

\section{'National development' strategies}

In their varied ways, the countries mentioned above have sought to counter their chronic dependence on the international capitalist system by attempting to take control of their most important national resources, of the mechanisms through which surplus was extracted from the country and to use this control to replan the direction of development, restructure the economy and lessen the necessity for dependence through diversification. One key part of the diversification has involved a redirection of the surplus to support indigenous industrialisation, under national ownership. Moreover there has usually been an effort to move into a different set of industries - not the import substituting, luxury consumption ones that have typified most neomcolonial experiences - but to include both mass consumer goods production (which will 
have a larger market capable of expansion over a long period) but also various producer goods industries. The Algerians have called what they opted for "the industrialising industries, " ${ }^{2}$ to emphasise the deeper linkage effects of these kinds of industries. Such ambitions in turn generate a $\operatorname{logic}$ for some degree of greater equalisation of an "income distribution (which) produces the demand profile most attractive to MNGs. " 3

This kind of model, seeking national development, has thus tended to be coupled with what have been termed "socialist" goals, in the sense of greater equality. The extent of measures for such income redistribution have varied, and the practice has not always corresponded to the rhetoric. But curbs on salary levels, on the number of salaries that can be earned, the shifting of tax burdens to salary and high wage earners and away from low wage workers and peasants, real increases in the minimum wage - all of these have been features of recent policy in Tanzania, to take one example. There has often been a related attempt to adjust to a more equal sharing of power as well as income. The old neo-colonial path which catered to and reproduced this structure of high incomes for a minority, was underwritten by the monopoly of power enjoyed by this minority. Thus the logic of the model also dictated that a democratisation process be also on the agenda. Again the extent in commitment and in practice to such goals has differed, both at the. level of national policy making and planning and at the level of the economic unit. Thus Algeria did foster some self-management at the enterprise level, although it has been suggested 4 that the plans from 1967 were accompanied by the subordination of these self-managing units to bureaucratic control, while at a national level it is only now in 1976 after 14 years that some tentative steps to a democratic and nonmilitary state are being initiated. In Tanzania the democratisation of party and state institutions has been a rhetorical commitment, but in practice leads merely to a circulation of power holders from the same bureaucratic and professional class, apart, that is, from the imposition of "leadership conditions" which have been relatively successful in excluding the property owning members of the bourgeois and petty bougeois proper from occupying state office. In that country a formal mechanism of "worker's participation" is in practice subject to manipulation by the managers of state enterprises. ${ }^{5}$ somalia is a country which by all accounts is giving more attention to the creation of new institutions of popular participation than many such regimes. Under this heading of the welfare aspects of the strategy we should note a common emphasis on the much broader provision of education as well as other social services. Somalia and Tanzania have each had their mini-version of the cultural revolution. 
Of course what must also be recognised is that measures like that of the Tanzanian leadership conditions, while trying to prevent an exploiting class from being literally a "ruling" class as well, do nothing in themselves to change the class structure of the society and do not necessarily have any final impact on the domination of this or other classes. Indeed, as we shall further elaborate below, one limitation of these strategies is that they do not give much weight to efforts to transform class structure and class dominance.

This limitation relates in turn to another dimension of strategy which in many of these cases is not given a prominent role - the agrarian sector and its structural change - although there is in this connection perhaps a greater degree of difference. In Egypt, for instance, the strategy of national development initiated by Nasser did include a provision for a classic land reform involving redistribution from feudal land owners to some peasants and land ceilings. In Algeria, apart from the necessity of making some provision for the vast areas of vineyards and farm lands abandoned by the French colons, any further steps of land reform had to wait until 1974. Since then there has been some gradual promotion of cooperatives. Tanzania is one country that declared for a much greater agricultural than industrial emphasis in its 'selfreliant' strategy - whereas most of our cases have had a much more industrial bias. Also Tanzania differs in that the strategy there included an attempt to eliminate class differences throughout rural society albeit these were the kulaks emerging as a result of the comercialisation of peasant agriculture rather than feudal remnants. In Ghana and and Mali during their periods of 'national development', there were some agricultural production cooperatives set up, and also a few state farms, but these were isolated "projects" rather than a programme that could be universally applied. In the event, the Tanzania regime did mount a campaign which led to the upheaval of a majority of the peasant population but one which did more to redefine bureaucrat-peasant relations than to change the relationships of production.

But the policy towards the agrarian sector had other implications for the overall strategy. We have already suggested that these experiences have at their root a desire to halt the flow of surplus from the country, and act to seize control of the institutions that appropriate the surplus aiming to redirect its use. But the targets for the nationalisations that are used to effect this control are the banks, finance houses and trading campanies through which the surplus is expatriated and those industrial ventures that do exist. However, in African countries, while these measures may be of some significance, these are not the institutions that generate most of the surplus. The industrial base is 
usually so small that there can be little hope that industrialisation can be self-financing. The financial and commercial sectors may handle a proportion of the surplus but this mostly comes from rav material production.

In most African countries such surplus as there is that can in future be tapped to promote self-reliant development comes from agriculture. To the extent, therefore, that an increased agricultural surplus is not generated or is not available for investment in industry and infrastructure, the whole strategy will lack the necessary steam and is likely to falter. This requirement of an agricultural surplus is difficult to realise simultaneously with other objectives. If a transformation of agrarian structure is attempted, opposition from landowners or rich peasants or an overly rigid bureaucratic hold on the process may reduce the surplus in the short run, unless the tactics are well thought out. Alternatively without such transformation, the backward productive forces that characterise agriculture (especially in countries like Somalia, Ethiopia, Mali, Tanzania) are not likely to be developed, and there is also the danger of a "scissors' effect": if peasants are squeezed too hard or not offered incentives they may withdraw into subsistence. These latter trends have been observed in Mali where production of the main cash crop fell sharply during the 1960's campaign to "restructure production," 7 and more recently in Tanzania during the most heavy handed phase of "villagisation." There were heavy penalties to pay for these effects of bureaucratisation. The severe economic and financial difficulties in the Tanzania case provided the opportunity for international capitalist institutions to resume control and in Mali lead to the coup which ended the whole exercise. The dangers of a bureaucratic solution to the agrarian problem underline, of course, the general importance of the political component in such strategies if they are to lead to a transition and not be reversed.

In some of the countries following such strategies the agrarian problem becomes slightly less central and less complex as their surplus arises from mineral production. Thus Algeria could, in one sense, afford to wait for 12 years before tackling the problems of agrarian reform because a considerable and capital intensive programme of industrialisation could be financed with the oil and gas revenues. There is some indication that the production of bauxite and iron ore may play a similar role in Guinea, whose export earnings are expected to increase fourfold by 1980 as a result of new mining ventures in the last 10 years, and in fact they already provide two-thirds of government revenues. This country has also not undertaken any major transformation of agriculture, even settler plantations still continuing to operate. Increased production has 
been sought through state farms, mechanised brigades servicing peasants and bureaucratic efforts to enforce minimum acreage rules for each family. But the readier availability of a surplus for industrialisation in these mineral producing countries has been achieved at a certain price in relation to the overall development strategy. The mining operations have involved deals with foreign companies and loans from international agencies and thus foreign capital, through its management agreements, has been able to retain an important say in certain development decisions even though the state has kept a sizeable stake in the companies set up (though in Guinea some of the joint ventures only involve a $49 \%$ government share). Both Algeria and Guinea have also retained many features of a monoculture economy and have been susceptible to pressures on prices of their main commodity.

Further problems with the mining economies have been their high technology and capital intensity. Algeria's strategy has aimed to develop oil and gas at the most rapid rate and during their lifetime install a high technology industry in the belief that independent industrialisation will ultimately become possible on this purchased base. But as Annerstedt and Gustavsson note, this logic may well substitute a new form of technological dependence through deals which will make the transnational corporations with their monopoly of new technology indispensable. In addition, the employment generation in mining is so small and is not increased much by the Algerian type industrialisation, that chronic unemployment and marginalisation occur. In Algeria, only 185,000 workers are employed in manufacturing and even the continuation of massive emigration of workers to France and elsewhere does not solve the mounting pressures. It is in these circumstances that the Algerian government is being forced belatedly to turn more attention to agriculture. The consequence of earlier concentration on oil and modern industry has been a steady decline in agricultural production such that almost one third of the oil revenues go to purchase food imports. So even if agriculture is not looked upon as the source of the surplus, the complex process of agrarian transformation must be on the agenda in the mineral rich countries if a national development strategy is not to falter.

\section{The socio-political base}

With differences, some of which we have noted, it is possible to note some common features in a strategy of "national development" pursued by some progressive African states. Moreover, with greater degrees of difference, such strategies tend to conform to three other themes in addition to the emphases noted earlier on nationalisation, industrialisa- 
tion and planning. These are measures for income equality and improved social welfare, agrarian transformation or reform, and democratisation of the political and production structures. Before pursuing further the evaluation of strategies in practice and trying to assess to what extent these countries' development path does differ from the more common neo-colonial pattern, it is worth trying to understand the social and political circumstances that gave rise to such trends. Are these strategies embarked upon in states which have a different history? To what degree do they differ in their position within the international division of labour, in the class struggle that they have experienced from the social formations that are proceeding on a neo-colonial path?

As the difference in development is more at the level of the state's intentions and not the performance, this does suggest that such explanations have to be sought at the level of the political superstructure and, as some have suggested, in the "subjective creativity" as much as "objective determination. "8 8 But in trying to assess the relative weight of variations at the political level and more basic social forces, it is worth noting the two sets of political circumstances in which such strategies have emerged. Two broad categories of experiences "of alternative to the capitalist model" have been noted. ${ }^{9}$ Angola, Guinea Bissau and Mozambique all represent states that have emerged as a result of a protracted national liberation struggle. The strategies that these new states pursue in the next few years may thus owe much to a process of social revolution, which in turn could be seen as flowing from the terms of the articulation of these social formations into the capitalist system and the consequent social forces: settler presence and 'super-colonialism', extreme alienation of peasants in brutal patterns of forced labour, absence of an indigenous bourgeoisie. Their future development may in turn owe much to the social processes generated by protracted guerrilla struggle - reliance on and mobilisation of the peasantry and workers, an anti-imperialist stance, and the pioneering of alternative production and social institutions in the liberated areas. However, most of the cases considered here do not fall into this category - one whose development it is perhaps too early to evaluate. The extent to which Algeria corresponds to this type is a matter of some debate. Clearly a long anti-colonial war has some significance but some have argued that this was limited because (a) the struggle took more diplomatic and conventional militaristic forms in the later stages and (b) because the present state is as much a product of a coup by a section of the liberation army after independence as of earlier events. 
The more common brand "consists of ruling parties and movements which inherited a "neo-colonial" situation but have rejected it... (through the) sometimes more testing process of peaceful change." But it is useful to go beyond Davidson's formulation and recognise that these cases we have considered represent two types of political evolution. This formula fits those of Ghana, Guinea, Mali and Tanzania where the strategy was a result of an evolution in the thinking of the ruling group "rejecting" neo-colonialism. In Egypt, Somalia and to the extent that they have introduced reforms the present Nigerian, Malagasy and Ethiopian regime, the new departures in development followed a military take-over or a palace revolution within a military regime. In the former cases the basis was slightly different in that the regimes carried the kind of popular support from most classes enjoyed by nationalist movements on the morrow of independence but recognition of this support does not explain attempts at a new path, it can only have been a facilitating factor. Likewise, the political character of the nationalist movements might have been something to use in building channels for participation by classes other than the dominant petty bourgeoisie (though in practice these opportunities were seldom seized on) but they certainly did not provide an irresistible popular ground swell which dictated the progressive policies.

Correspondingly in the military states it is difficult to point to the existence of conscious and vigorous popular pressures as the root cause of progressive regimes. Although there may have been discontent among workers and peasants and, frequently, widespread accusations of corruption which were articulated by the instigators of a coup, experience shows that this background can just as well lead to reactionary military rule. The trends set in motion by the Egyptian army under Nasser, the Somali military, even that of the sudan during one brief period, and now haltingly the Nigerian and Malagasy are to be more sought in the ideology of certain factions within the military and their tactical success. The temporary character of this success, as evidenced in Egypt and the Sudan or similarly in Peru and Bolivia, is of course a necessary consequence of the "opportunistic" circumstances that have lead to such changes - as we shall further explore below.

Ethiopia is interesting in that the military regime there has to be seen much more as a product of broad revolutionary forces in the society - the demands of peasants, workers and the 'marginalised' urban dwellers and their exploitation under a feudal or tribute-extracting social formation eroded by the spread of capitalist relations of production. Here the political reforms and the partial agrarian reform have perhaps been more forced on the military government by the logic 
of the situation - and already the Dergue is becoming increasingly the instrument for seeing the revolution stops short and does not lead on to a transition to socialism. Here it is perhaps worth comparing with the case of Zanzibar where the intense nature of the class struggle which created more 'objective' social conditions behind the seizure of power, and thus placed a socialist transition on the agenda. Here again the ruling group were not the initiators (as with most of the other cases) of reform; they had to respond to certain basic forces (the expropriation of Arab plantation owners for instance) but quickly, and relatively easily, were able to hijack the revolution for more personal ends.

With these two partial exceptions then the emergence of a ruling group articulating a strategy of national development has been a process to be explained more by the conversion of a few individuals who have been prepared to go beyond the orthodoxies of their class, or as a result of a seizure of power by such a group. The socio-political base on which their power rested and which is available to support the strategy is typically very narrow and thus precarious. To that extent the toppling from power of Nkrumah or Modiba Keita, without the slightest popular resistance, is not surprising lalthough the particular circumstances should be explored). The demise of their regimes, so quietly, is a function of the fact that their strategies were, from the outset, efforts made against the odds. The fate of their regimes, and hence their rhetoric if not the policies, is paralleled by the ease with which major policy shifts away from any transition have occurred in some of the other states. In Egypt the "socialist" forward thrust was played out before Nasser's death; after it, a smooth inheritance of power led to an equally uncontested reversal of many early measures such as the return of 'reformed' land to former landowners, the opening up of the economy to foreign capital, and the increasing closeness to the West.

We should finally note that the relative ease with which such strategies are reversed is measured not simply by the absence of popular resistance to such reaction. In instances such as Ghana, Mali and Egypt a great amount of institutional dismantling has not been required. There was some selling back of state industry to private capital in Ghana but otherwise the state capitalist structures that had been set up could be easily reshaped to serve the ends of monopoly and local capital. Indeed, as we shall see below, some observers have argued that this did not represent much change. In the case of Ghana, state capitalism was seen as benefitting transnational corporations at the expense of the native bourgeoisie; ${ }^{10}$ in Mali, it was argued that the state enterprise managers had in fact become a class, using their control over capital to accumulate in their own interest. 11 
Of course, many of the architects of these strategies have been aware of their inviability without some political transformation that could generate a much wider support as well as a much more reliable organisational instrument for implementing the policies. The military regime in Egypt tried to set up a socialist party - and their example was, also unsucessfully, followed at one stage in the Sudan. Now the Somali Government is about to embark on the same task-- although the intention there seems to be more a vanguard party of cadres as opposed to a mass movement. The Tanzania strategy, partly learning the lessons from Ghana and then in 1971 of external and internal sources of attempted coups in Guinea and Uganda, includes a political dimension which seeks sweeping changes. We have already mentioned the leadership conditions prohibiting party members and civil servants from owning all but the minimum of property or having business interests. This could only eliminate the grossest kinds of self-interest. Elective mechanisms were introduced for Parliament, all levels of party committees, local development bodies and even in work places. Beyond these institutional changes, political education programmes were announced, directed at the higher levels of education and even existing functionaries in an effort to imbue them with a non-elitist perespective, as well as at the workers and peasants. This latter could have helped to generate class consciousness and a greater ability to defend their interests in day to day dealings with the state and in time of invasion or subversion, especially after the intensified programme introduced in 1971 together with a people's militia - but the content was not in terms of class struggle.

What few of these regimes have sought to do on any significant scale, even if they have aimed at some measure of democratisation, is to develop a vanguard, Cabral's "party within a party," to train and use 'cadres' in the sense of combining ideological commitment with a style of political work which is anti-bureaucratic and could mobilise workers and poorer peasants from below. Ideological institutes like Nkrumah's have appeared but no cadre deployment at grass roots level occurred. Tanzania did make one or two efforts to build up such a counter-bureaucratic team of cadres within the party (for ujamaa, for political education, for workers' educational programme at different times) but these small attempts were quickly subverted by bureaucratic intervention.

The importance of this step of developing cadres - one that has not been successfully negotiated 'from above' in Africa so far (though is now seemingly being attempted by Somalia), lies precisely in the fact that a strategy is articulated containing steps which might lead to the prospect of a transition to socialism, but such a path is being put 
forward in the absence of revolutionary political conditions. Such a transition depends on the awakening of worker and peasant class consciousness and the effective mobilisation of these classes into organisations through which they can defend and promote their interests. This condition is critical by virtue of the fact that the development initiatives are unlikely to be able to survive long enough to reach the point when a transition to socialism becomes possible in the teeth of bureaucratic encroachment or of other shifts in the delicate balance of power that made the initiatives possible. At the same time, the necessary class consciousness - of workers able to challenge state managers, of peasants able to confront kulaks, landowners and bureaucrats - will not arise entirely spontaneously. And, moreover, the mobilisation of workers and peasants is not a task that can be accomplished by the inherited state bureaucracy, however wellmeaning the leadership.

It is this transformation of the very character of politics which, while not ruled out by definition, is nevertheless the most complex and difficult part of the laying of any foundation that would make a genuine transition possible. The fact that regimes wedded to "socialism" have not attempted or not succeeded in it largely explains why other elements of strategy, as we shall now see, are of ten not translated into practice and also why the commitment to national development and even the persistance of ruling groups of this sort is often shortlived.

\section{National development strategies - the performance}

What coherence there may be in the policy statements spelling out the different countries' strategies, this coherence begins to disappear when we look at the actual practice. We have already touched on some of the short-comings but here it will be useful to categorise the major difficulties, and in this connection a list prepared by Mafeje is worthy of reference. ${ }^{12}$ He emphasises the tendency for "socialist" strategies seeking an alternative way to neo-colonialism to be characterised by bureaucratisation, a retention of production structures, slow technical progress, and low growth rates. The first of these tendencies, as we have indicated in the section above, is part explanation for the other failures. Certainly Mafeje sees the slow economic growth as attributable to the inefficiency and consumption of bureaucracy, and earlier we suggested how the typical bureaucracy is incapable of a sufficiently flexible approach to agrarian transformation or of popular mobilisation. But apart from the inadequacy of bureaucratic styles of work and structures, more fundamental problems of implementing the strategies result from the combination of the bureaucracy's degree of freedom in the absence of the domination of the state by other classes together with the 
the bureaucracy's own class origins and aspirations. For "implementation" is itself an area which provides for much subjective creativity and all too often there has been a distortion and even a reversal of the policy aims. In broad terms there is as a result of bureaucratic subvertion, but also more objective factors, first some doubt as to whether the embarkation on development strategies has significantly reduced the role of the influence of international monopoly capital in the social formation.

The bias in the industrialisation programmes, the lack of technical ability on the part of the bureaucracy and their reliance on foreign technology, together lead to a pattern of "technical dependence." Here we should note the discussion of Annerstedt and Gustavsson about the significance in the new international division of labour of the MNC's monopoly of technology and of the control that can be built on the sale of technology not needing local, formal ownership. Their arguments correspond to those of Mafeje about the reliance on the importation of technology, which he argues in turn involves a skewing of skill formation (and we might add for a particular pattern of class formation) and increasing unevenness between sectors. He also emphasises that the selfreliance such strategies aim at is not achieved in another respect. There is no marked shift in the types of industry given emphasis. Breweries tend to be the most rapidly growing state enterprise. Thomas' conditions of the identification of production with demand let alone of social needs are not met.

We can, finally, note two other related limitations in the nationalisation industrialisation strategy. First, Sachs ${ }^{13}$ has underlined the need for the state to take over some sectors of above average profitability in order for it to accumulate surplus for future investment - and also because otherwise state industry will be indirectly subsidising private enterprise. In fact this seldom occurs, the state role often being limited to entrepreneur those sectors which, though some are of strategic significance, are those not immediately attractive to private capital. A corollary of this is that there is a danger in practice of a de facto division of labour between parastatals and private capital which (whatever the overall quantitative balance or pattern of ownership) works to the advantage of the latter. And moreover partnerships of state and monopoly capital in key industries can do as much to ensure capital's control over state planning as the reverse. There is, in reality, only a thin dividing line between the state capitalism characteristic of "sub-imperialist" states and those described as taking the 'non-capitalist' road. In both, the state sector is significant and 'industrialising industries' are on the agenda in each case. And for the same reason 
the economic institutions set up in a 'progressive' phase, can easily lend themselves, once there has been a shift in the ruling group or a change of heart, to this kind of 'sub-imperialist' pattern where state capitalism is used as a vehicle for a development path suited to the transnationals and involving increasing exploitation of the working class and the marginalisation of much of the rest of the population.

\section{Bureaucracy, the state and class struggle}

The above recognition of some of the limitations of the 'national development' strategies, raises questions about the adequacy of it as formulated, especially in the 'classical' form defined at the beginning of the paper. And this seminar might usefully take up the challenge in Annerstedt and Gustavsson, and tackled by Thomas in his study, of suggesting strategies for transformation which could lead to the prospects of a real transition to socialism. However, this is a different question as to whether attempts to follow such strategies will lead to a transition, or will even be able to fulfil their own objectives. Indeed my conclusion from this brief survey is that unless the 'progressive' phase does lead to a transition - or to put it more forcefully, unless advantage is taken of such openings, the impetus (often based initially on a precarious base) will tend to die away and the path be reversed. Whether this reversal will occur depends in part, we have argued, on the bureaucracy. Certainly the natural tendencies within bureaucracy will serlously weaken the impetus to transition. It is here then that the role of other classes becomes crucial. Without a strong thrust from workers and peasants, 'national development' strategies will deteriorate and not lead to a transition to socialism.

What then follows from this rather non-controversial proposition? It is not enough just to argue that the class basis of the state in these countries is not yet ripe for beginning a transition from capitalism, is 'petty bourgeois' etc. Rather I think it possible that for reasons which are in part 'accidental', in certain states a group has gained some (limited) access to power and enunciated a strategy for halting the neo-colonial trends. Moreover, whether such strategies are even followed will itself be a matter for ideological and thus class struggle. A struggle between 'two roads' will always be ocurring - in the planning process and other policy making, in the concretisation of plans, in the implementation of programmes and in the running of production units. In these different levels of struggle, the building of the organisational strength and consciousness of the workers and peasants - by a variety of means not only by a 'workers party' - will obviously be crucial. And of course individual radicals can and should help in this 
creative role. But another set of conclusions can also follow. The strength of proletarian forces can be heightened by political work and state power could be utilised in this work, but the relative strength of these class forces is a reflection of more basic forces - not just the level of productive forces in a crude technocratically determined way but the relationships of production and the related class formation. Here again, the conclusion should not be to react to the opposite extreme of a defeatist and deterministic conclusion, that such attempts to move to transition are 'premature.' Our attention must then be directed to the analysis not only of the state (even the progressive ones) but just as Cabral did for colonial Guinea Bissau, look at the revolutionary potential of the emerging class formation (in which classes to seek a base, from where to derive the cadres, and the content of political education directed to workers and peasants).

\section{The effect of national development strategies on class formation}

It is now possible to say something about "strateyy" in the sense of revolutionary methods and tactics, in 'progressive' states. The paper has argued that such states are not even at the point of the beginning of transition to socialism. They have at best set up some instruments of state capitalism and have generally done so on a limited political base, and such openings are likely to be only temporary and can easily lead to some capitalist road instead of a transition to socialism. At the same time this conditions do represent a different set of circumstances, even if only for a time, there is an 'opening,' and for revolutionaries this is an opportunity not to be missed. But the class structure, which will provide the broad limits of what is possible in these circumstances, is itself not a given. The articulation of non-capitalist modes of production with the international capitalist mode means that the class formation is complex (and not bipolar), is itself in transition and moreover is subject itself to further shaping by the very development strategies that are being debated and put into practice.

It is in this context one can see one very basic limitation in the strategies that have often been attempted. Successful or not, implemented or not, they have been chiefly, and understandably, conceived as antiimperialist strategies in the sense of changing the terms of the country's involvement in the international division of labour. They have sought to build a base for "national development." And this has been seen as the first stage that could lead (as indeed it conceivably might) to a transition to socialism, a phase that is 'national democratic' and in which an alliance is possible with petty bourgeois and other class forces that are anti-imperialist. But we have seen that the allies come all too easily to gain eventual dominance. Yet political work and cer- 
tain types of organisation can limit this but so too can certain strategies. The task of this seminar might therefore be to discuss what elements should be given greater weight in a development strategy that is not only promoting a national base for industrialisation but is actively changing the balance of class forces. This is the chief criticism of strategies which are seen at their most extreme in the case of Algeria. The economic base has been changed but the class structure altered but little, still a tiny industrial working class, the peasantry still a victim of fragmented consciousness and becoming increasingly a lumpen, marginalised element. If there is any opening, for a short time, because of a progressive shift in power then what follows from this analysis is how strategies are urged in the short run which can ultimately generate the popular forces needed for transition.

\section{Conclusions}

This leads to two conclusions whose importance is in direct proportion to the brevity with which they are expressed:

1) Greater emphasis on industrialisation which will most rapidly increase the size of the working class.

2) Concentration on transformation of agriculture but also of all other non(pre)-capitalist modes of production.

If state capitalism is the answer for the moment in some sectors (those which are already or can easily be given over to capitalist production), what is even more crucial to the prospects of transition is the handing of the second and more complex problem, the pre-capitalist modes and their rapid, if partial, transformation by methods which can project and give force to the contradictions inherent in the conflict of these modes with capitalism. 
NOTES

1. J. Annerstedt \& R. Gustavsson, Towards a New International Economic Division of Labour? Patterns of Dependence and Conditions for Liberation in the Periphery of Capitalism, (RUC Boghandel, Roskilde, 1975).

2. J-C. Martens, Le Modele Algerien de Developpement, (SNED, Algiers, 1973).

3. C. Furtado, "The Brazilian 'Model' of Development", in C.K. Wilbur, ed., The Political Economy of Development and Underdevelopment, (New York, 1973)

4. H. Clegg, Workers Self-Management in Algeria, (Monthly Review, New York, 1971) and a review of Clegg by J. Hagel in Review of African Political Economy, No.6, 1976.

5. Paschal Mihiyo, "The Struggle for Workers Control in Tanzania", Review of African Political Economy, No.4, 1975.

6. See Basil Davidson's account in Socialist Register, 1975, (Merlin, London)

7. Guy Martin, "Socialist Development in Mali, 1962-68", Canadian Journal of African Studies, 1976.

8. The phrases are taken from A. Mafeje, "Socialist V. Neo-colonial Strategies", (mimeo, Le Hague, 1976). Similar arguments relating to the 'pliability of the state' can be found in J. Saul, "The PostColonial State", Socialist Register, 1975, (Merlin, London).

9. Davidson, op.cit.

10. B. Fitch and M. Oppenheimer, Ghana, End of an Illusion, (Monthly Review, New York, 1967).

11. C. Meillassoux, "A Class Analysis of the Bureaucracy in Mali", Journal of Development Studies, 1970.

12. Mafeje, op. cit.

13. I. Sachs, The Public Sector in Developing Countries, (Bombay, 1969). 
Timothy Shaw \& Malcolm J. Grieve

DEPENDENCE OR DEVELOPMENT: INTERNATIONAL INEQUALITIES IN AFRICA

The political economy of Afxica has recently begun to receive proper attention and analysis. This essay is a modest contribution to our understanding of internal and international inequalities in Africa; it is both a review of the existing literature and a preliminary attempt at further conceptual development. We largely share the premises of Richard Harris that

". . an understanding of contemporary Africa.. . can only be advanced by making a radical departure from the assumptions and modes of analysis associated with (the) conventional wisdom . . the political and economic life of the African states cannot be adequately understood if we restrict our analysis to internal or domestic factors within the individual states". 1

We suggest that African politics can be best explained by concentrating on the linkages between "external" and "internal" actors: it is through relations at this interface that the political economy and international status of each state are largely determined. ${ }^{2}$ The alternative strategies of collaboration or confrontation adopted by African regimes to external threats and opportunities have led to dilemmas and defeats over time. ${ }^{3}$ The uneven rate of political development and decay requires an historical as well as a critical perspective. The analysis of dependence and underdevelopment in Africa has already been advanced by a few students of Africa's political economy--Samir Amin, Giovanni Arrighi, Arnilcar Cabral, Basil Davidson, Rene Dumont, Frantz Fanon, Colin Leys, Kwame Nkrumah, Ann Seidman, John Saul and Immanuel Wallerstein ${ }^{4}$ - and their formulations have now been developed by a new generation of critical scholars - for example, by Robin Cohen, steve Langdon and Richard Sandbrook. This essay is intended as a small addition to this development and debate and focuses on the central linkages between the state in Africa and its foreign associates.

Although we do not yet have a fully developed theory of the state in Africa" it is clear that the "state structure has served as the main instrument by which the African bourgeoisies have imposed their domination on the subordinate classes and secured their privileged position in the present neo-colonial system." 6 Indeed, because the ruling class in Africa is essentially dependent and not a "national" bourgeoisie, it 
has come to rely on external support rather than on its domestic constituency. Further, because it is often unresponsive to internal inequalities and demands, it comes to rely on coercion as well as patronage for control. Yet despite the long history of dilemmas inherent in collaboration, Africa's leaders still seek short-term gains through external associations. Indeed, given the pathology of underdevelopment and the elusiveness of development, such instant panaceas remain seductive. Nevertheless, in the absence of real national development strategies, integration into the global economy leads characteristically to foreign policies of compromise and to domestic regimes of repression. ${ }^{7}$ Moreover, uneven rates of growth among African states have led to increased interstate inequalities on the continent.

Africa (as well as Tanzania ${ }^{8}$ ) lost its innocence in its first decade of recaptured independence. In its present second decade, with the failure of optimistic solutions and predictions, more critical analyses and better-defined development strategies have produced better informed and more appropriate proposals. However, the new elites of Africa's states remain unprepared for any radical change that upsets their comfortable relationship with the external estate. To be sure, they are concerned to maximise benefits for them from foreign associates but they are not yet willing to restructure their political economies and external linkages. Opposition to the new class has been limited or contained to date. Indeed, rather than revolution and socialism, authoritarianism and regime violence are likely to characterise African political economies and external linkages. Opposition to the new class has been limited or contained to date. Indeed, rather than revolution and socialism, authoritarianism and regime violence are likely to characterise African politics in the future because of the elusiveness of development and the need to reinforce elite control and affluence. Given the false starts, the absence of growth or redistribution, and the underdeveloped class structures of African states, ${ }^{9}$ the trend is now towards "departicipation"10 or centralisation along with coercion rather than to "modernisation" or "development". 11 This essay is concerned, then, with both the international and internal political economy of Africa, and analyses the impact of inequalities both within and between states.

The political economy of the state in Africa

Independence in Africa meant a change of the dramatis personae in the state. However, it did not often involve the re-establishment of 
national control over the economy or society. ${ }^{12}$ Rather, formal political independence stood in contrast to continued economic and social dependence. 13 The new ruling class, especially in the more dependent countries, were able to rule only through collaboration with external interests; to disengage meant isolation, Intimidation and obscurity-a situation that most first-generation nationalist leaders sought to avoid. Foreign associations also offered the prospects, if not the reality, of aid and capital, technology and skills, markets and money. uhuru meant new demands on leaders for visible growth and continual patronage; the external estate helped to satisfy these initial demands.

However, the elusiveness of real economic and social independence has led to coup d'etats, military regimes and one-party states, all designed to maximise control over the state and to achieve political order if not development. Increased coercion and control have become imperative because of the process of underdevelopment and the powerlessness of the state in Africa to contain that process. To overcome the dilemmas of dependence, the new class could intensify its external relations or change both its development and foreign policies to transform its inherited political economy. The incumbents in most African states opted for collaboration rather than confrontation; only the few chose to alter their external linkages. There are, of course, great difficulties for small and poor African states in changing both their internal and external political economies; indeed, the intensity of Africa's dependence has led to a retreat from, rather than confrontation with, the problems of development. The primary reason for this is that the new class

... is not a class which is development-oriented ... it forms either an expensive facade for a nation remaining basically stagnant and deprived, or a de facto intermediary for, ally of, and expense upon, continued foreign economic penetration and domination. These characteristics go a long way ... towards explaining the fragility of African political systems ... An elite which preaches austerity, efficiency and development, but which practices luxury (for itself and its government) combined with inefficiency, and which produces very limited social or economic advances for the vast majority of the population - is inherently unlikely to maintain broad domestic backing. 14

Most "political change" in Africa to date has been within the ruling elite and has not led to a significant redefinition of any state's role in the global political economy. We suggest, therefore, that the orthodox distinctions between civilian and military regimes, one- and multi-party states be superseded by a typology which is based on the nature of a state's external and internal linkages. Such an approach would emphasise the salience of relations between external actors and 
and the new class and the importance of the external 'constituency' for the domestic political economy. The relationship between the ruling elite, the labour aristocracy and the peasantry is conditioned by the former's place in world politics; the extent to which the new class is a "comprador bourgeoisie" is of great significance for the character of "internal" political economy.

The cluster of relations around the new class largely determines the character of an African state's political economy. We suggest that a distinguishing motif for the two dominant types of political economy found on the continent is whether they are "state capitalist" or "state socialist" regimes. Both types reflect the trend towards a concentration of power and affluence around the state; however, a crucial distinction has to be made between those states that encourage private capital (e.g., Nigeria, Egypt, Ivory Coast, Kenya, Senegal) and those that insist on community ownership (e.g., Tanzania, Somali, Tunisia, Algeria, Mozambique, Angola). In both instances, the state exerts an increasing monopoly over decision-making, but in the former control, income and status are distributed to individuals while in the latter they flow to new institutions established by the state. We have indicated elsewhere how this distinction cuts across the macromegions proposed by Amin: ${ }^{15}$ each of his regions, despite their general colonial role, now contains a variety of political economies. ${ }^{16}$ Rather, the nature of different states in any region in Africa is related to the interests of external actors in "regional integration". As indicated (in Section iii) below, the "great" powers in Africa are largely those that are most permissive towards external actors: they are state capitalist rather than state socialist regimes reflecting the mutual interests of foreign and domestic elites. There is a high correlation of coincidence of interest between state capitalist governments and the interests of external states, entrepreneurs and corporations. 17

Although independence has had a minimal and delayed impact on the political economy of African states it has made the "national interest", as defined by the ruling class, a legitimate concern in the bargaining process between regimes and foreign actors. Although we largely concur with Wallerstein that "the independent governments of Africa are far more efficacious 'indirect rulers' than the obas and mwamis of the colonial era"18 it is clear that a few states have begun to change both their external associations and their internal structures. Indeed, one reason for the primacy of state capitalist regimes is that to achieve socialist development both international and internal relations have to be altered simultaneously. As dos Santos notes: 
... if dependence defines the internal situation and is structurally linked to it, a country cannot break out of it simply by isolating herself from external influences ... The only solution therefore would be to change its internal structure - a course which necessarily leads to confrontation with the existing international structure.19

Economic and political development in Africa--including any progress towards state socialism--require a strategy which confronts both established external ties and internal structures, one that does not accept Africa's inheritance of dependence on either the global economy or on an unequal international division of labour. A few African states have attempted this transformation, often with a lack of success (e.g., Ghana, Mali, 20 Egypt, Libya, Algeria, Sudan under different governments). only a few regimes have had sufficient longevity, innovativeness and support to undertake a sustained, longer-term reassessment of their inherited dependence and underdevelopment, but their experiments have produced various contradictions inherent in state socialism rather than any progress beyond in the direction of a more democratic, decentralized African socialism (e.g., Guinea, Tanzania, ${ }^{21}$ Somalia and now GuineaBissau, Mozambique and possibly Angola).

The characteristic dependence of African states and regimes on the global political economy leads to fundamental and largely overlooked questions about the nature of the state in Africa. In imperial systems, colonies and their administrators were clearly subordinate to the metropole. In "neocolonial" Africa, new states and leaders have limited choice and autonomy, and yet "we have no fully adequate theory of the 'neo-colonial state', its relation to international capitalism and domestic classes and its consequent role in the production process". 22 If we are to begin to explain the undexdevelopment of Africa, its characteristic state capitalist systems, and its continued reliance on foreign aid, capital technology and markets then we clearly need to develop theories of the state in Africa.

Essential to any such definition of the state is the nature of parastatal structures. The political economy of parastatals is central because they are the institutions through which the state and external interests come to terms. ${ }^{23}$ The multinational corporation is a remarkably flexible institution and in the Third World it has secured access, profit and cooperation by permitting, even encouraging, national participation and limited regional integration. ${ }^{24}$ The corporation has maintained the flow of raw materials, perpetuated its monopolist position, and secured local advocates by entering into cooperative branch-plant arrangements with national regimes or share-holders; ${ }^{25}$ local incorporation and direction has enabled it to continue its "global reach". 26 
However, parastatals differ greatly in their nature and importance. In particular, some parastatals constitute an indirect way of developing state capitalism through individual share-holding, whereas in state socialist regimes the government holds the local shares on behalf of the people. There is a major distinction between the impact and potential of parastatals in Nigeria and Kenya, ${ }^{27}$ for instance, compared with those in Zambia ${ }^{28}$ and zaire and those in Tanzania and Somali.

The characteristic "parastatal strategy" of Africa may then be an expression of nationalism (as in state-cpitalist systems) or a step towaras nationalisation (as in state-socialist regimes). State capitalism does not constitute a fundamental challenge to the inheritance of integration into the world economy, especially into corporate structures and into unequal exchange with advanced capitalist economies. Partial nationalisation through state socialism on the other hand does create the possibility of greater self-reliance and the potential for further moves towards a non-capitalist political economy. In the former, partnership with the multinational corporation is seen as the final stage of economic change; in the latter, the parastatal strategy is conceived as just one step towards other socialist measures such as more direct political or worker control, different operating criteria, and eventual full national ownership in some form of cooperative structure. ${ }^{29}$ However, we are not sanguine about moves towards and beyond state socialism because the interests of the new class are more vulnerable in a state socialist than in a state capitalist society.

Our proposed distinction between state capitalism and socialism is similar to that made by Ghai between on the one hand the "localisation of capitalism" and on the other a "socialist approach". 30 The Africanisation of petty capitalism and of branch plants has led to different policies and to a growing contradiction which a socialist strategy seeks to avold. Partial national ownership and participation should be distinguished from collective ownership--the former policy leads to the creation of inequalities and a "national" bourgeoisie whereas the latter has the potential to avoid the growth of such social inequalities. The socialist strategy in Africa faces problems of efficient national administration and the cost of appropriate technology; the localisation of capitalism approach leads to an inescapable contradiction:

This apparent inconsistency in policies towards two different groups of foreign investors and entrepreneurs, flows from an assessment of their roles in development and from the national socio-economic imperatives which they face. While the role of resident alien capitalists 
is often decried as exploitative and disruptive of the growth of indigenous entrepreneurship, international corporations are courted as carriers of modern technology, management, capital and new products.31

Indeed, as we note (in Section ii) below, a major conflict is emerging between national entrepreneurs and local participants in transnational capitalism.

Because of the multiple forms of dependence in Africa, confrontation with the multinational corporation by itself may not significantly improve the prospects for autonomous development. The establishment of a more self-reliant national, regional or continental economy is even more difficult and elusive than disengagement from relations with foreign companies.

Most states in Africa have export-oriented economies. ${ }^{32}$ Their economic prospects depend on the supply and price of their commodities, over which they have little control, either because of environmental vagaries or because of the unequal and oligopolistic structure of the world market. Only the oil producers have successfully changed the price and production structures of their industry and their "power" may be temporary and pyrrhic. Moreover, their affluence has been achieved at the cost of increased poverty in the least developed countries. ${ }^{33}$ Africa's dependence on international trade has been perpetuated not because it benefits most people in the continent, but because it benefits the leadership: "the state bureaucracy is likely to pursue policies designed to strengthen the power of dominant groups that may accumulate a major share of investible surpluses." 34 The dependence of states, (as we note in section ii below), is perpetuated by the interdependence of elites.

Seidman argues that more popular political participation is necessary to challenge this unequal distribution of goods and the "development planning" which perpetuates it. However, political change in Africa, in the form of successive coups or the transition to one-party systems, has consisted largely of a circulation among elites rather than opening participation to the poor. ${ }^{35}$ A greater degree of democracy can come only by fiat or revolution. In most African states, a "commanding heights" strategy has, paradoxically, reinforced elite privilege. Only in a few states has participation by workers and peasants been achieved, and the either by regime preference (Tanzania, Guinea, Somali) or by anti-colonial revolution (Algeria, Guinea-Bissau, Mozambique).

The perpetuation of export-oriented economies rather than the implementation of plans for more autonomous integrated economies either within African states or regions can be explained by reference to the 
emerging class structure in Africa. The new elites welcome rather than discourage the multinational corporation; they prefer policies of import-substitution to those of relevant technology or basic industrialisation oriented to agricultural needs. ${ }^{36}$ However, over time this strategy may stimulate those social forces it was designed to ignore and exclude, hence the reactive trend towards authoritarianism in Africa.

Establishing a system of state ownership within a capitalist world economy does not mean establishing a socialist economy. It may not mean improving the economic well-being of the majority of the population. It is merely a variant of classic mercantilism. But it does change the world political scene because it clarifies the role of monopolistic limitation via the state in the unequal exchange of world capitalism, and thereby in the long run affects the political mobilization of those forces who are discontented with the "limited possibilities of transformation" within the present system.37

The interaction of global and internal constraints and opportunities has led to increased inequalities within Africa, both among states and classes. Political independence has tended to increase economic dependence because the new ruling elite has needed control over patronage and symbols. The association between the "comprador bourgeoisie" and the multinational corporation has led to conspicuous plants and collaboration between indigenous interests and foreign capital. The new elite has adopted foreign incomes and tastes while most of the population has been largely forgotten and impoverished. At the regional and continental levels, those regimes most hospitable towards external investment and assistance have witnessed rapid economic growth which has enhanced their claim to regional hegemony. ${ }^{38}$ Contemporary Africa is characterised by greater internal and international inequalities than ever before. 39

\section{Internal inequalities and transactional class interests}

The increase in inequalities within African states is related to theix unequal status in the global hierarchy and the collaborative role of their elites. Indeed, the dependence of states is perpetuated by the interdependence of elites. ${ }^{40}$ Unequal exchange between states has not prevented the development of mutual interests between the new class and the external estate.

The cooperative relationship between local elites and the multinational corporation has led to a distinctive form of transnational politics in which conspicuous consumption and foreign management techniques are transferred to and adopted in the Third World. The common interests of the rich states and the rich in the poor states have produced a dominant transnational association ${ }^{41}$ which has conceived, implemented and controlled the characteristic parastatal strategy in Africa to advance both corporate and indigenous interests. 
Transnational integration encourages national disintegration and dependence; international cooperation produces national inequalities and underdevelopment. 42 This "radical" transnational approach focuses on the mutual gains of an empathetic and symbiotic linkage relationship between external and local interests in the periphery. States in Africa may be dependent, but given shared interests, foreign and domestic elites have a relationship amongst themselves approaching that of interdependence. The emergence of a relatively stable and symmetric relationship suggests that transnationalisation leads to cooperation rather than conflict. The tensions produced by uneven development lead to political problems in the periphery rather than among elites in the international system.

The transnationalisation thesis reinforces our scepticism over the "inevitability" of conflict between states. Dependence may be a more stable structure than is suggested in theories of imperialism. The "symbiosis" 43 of the African state and multinationals leads to mutual benefits--investments, patronage, corruption and style for the new elites and markets; security and influence for the multinationals. The latter are adaptable rather than transient, ${ }^{44}$ but the future of "neocolonialism" depends on the acceptability of the bargain arranged between domestic and foreign ruling elites. We have suggested that revolution is unlikely, either in African internal or international relations, in the near future. However, new parastatal agreements may modify the attractiveness of the arrangement for either partner. Over time the "balance of power" in the relationship may shift away from the colonial inheritance and towards a greater degreee of African influence and direction, especially if national resources or markets are of particular value to any corporation. ${ }^{45}$ The ability of national elites to extract more benefits from the transnational relationship may be crucial for its ability to repress, divert or co-opt internal opposition. Competition between national and corporate decision-makers takes place in the context of political demands within African states:

In peripheral areas of the world economy, however, the primary contradiction is not between two groups within a state each trying to gain control of that state structure, or to bend it. The primary contradiction is between the interests organised and located in the core countries and their local allies on the one hand, and the majority of the population on the other.46

The parastatal strategy has, thus far, not only reinforced the state-corporation relationship; it has also undermined any prospect of an indigenous entrepreneurial class developing in Africa. ${ }^{4}$ Indigenous capitalism in Africa cannot compete with the established linkages of 
dependence, the "monopoly in international commodity markets and monopoly in industrial technology". " 8 Local services develop largely in response to corporate penetration, not as an alternative to dependent industrialisation. The elimination of a national middle class serves the interest of both partners in the parastatal system. ${ }^{49}$ Internal "class" interests may explain much external behaviour of African states, especially their limited foreign policy "choices". 50

The development of a dependent capitalism in Africa has been effected partly because of the dominance of multinational corporations in the global economy. The "partnership" forged during the colonial period has been modified but not changed in its fundamentals. 51 "The elites do not grow into an independent bourgeoisie because they cannot do so. They remain the junior partners of an external system upon which, at all decisive points, they must continue to depend." 52 In both precolonial, colonial and post-colonial times, elites which collaborated with external interests became "parasitic"; "indirect rule" led to dependence not on traditional ties or an indigenous constituency, but rather on external associations. ${ }^{53}$ As Mwalimu Nyerere insists, there is only one rational choice for Africa--socialism: "Third World capitalism would have no choice except to cooperate with external capitalism, as a very junior partner". "54 However, as several critiques of the development of the Ivory Coast and Ghana show, ${ }^{55}$ a semi-capitalist strategy can be highly profitable in certain circumstances, both for the state and for groups within the state. Nevertheless, the cost of class-formation is high, heightened dependence increases vulnerability, and for Africa as a whole only a few successful capitalist regimes are possible.

The other, controversial class which affects both the calculation of the benefits and costs of collaboration and also the possibilities of conflict is the "labour aristocracy". 56 The emergence of a workers' elite in both state, parastatal and private organisations has served to widen the distribution of gains from independence and state capitalism and to co-opt a further social group thus reducing the immediate prospects for revolution. Despite some recent scepticism about the usefulness of the concept, 57 the approach is helpful in explaining the lack of militant worker activity in Africa above the level of economism. The defence of the idea by Saul, one of its major advocates, remains persuasive:

... the term 'labour aristocracy' helped to capture the reality that the most organised and articulate of those proletarianised by the imperial impact appeared to have been 'processed' in such a way as to 
facilitate their material and cultural identification with the system of neo-colonial domination .... it highlighted the irony of the fact that these elements were, of indigenous strata, at once the most exploited (in the scientific sense) and among the most 'benefited' by the system (in the absence of a very strong national bourgeoisie and certainly as compared with the great mass of semi-proletarianised or wholIy rurally-based agriculturalists) .58

The few nationals in this relatively lucrative employment not only have a position of relative advantage for themselves; they also constitute a standard for other workers, peasants and unemployed and so reinforce patterns of social control. While faith in development lasts, the prospect of recruitment into the labour aristocracy generates conformity; when, because of political change, population growth or economic stagnation, such upward mobility is clearly a dream, then opposition is likely. Thus far, in most African states labour has been quiescent in its relative affluence, except for demanding more privileges within the established political economy .

Together, the transnationalisation and labour aristocracy theses go some way in explaining the absence of revolution in Africa despite intensified inequalities and the paradoxes of state capitalism. Sandbrook and cohen assert, for instance, that

Regardless of how historically necessary or desirable a socialist revolution may be in the politically independent peripheral capitalist countries of tropical Africa, one is unlikely to occur in the foreseeable future. 59

Similarly, even Leys admits that, despite the trend to monopoly and conflict in the political economy of states such as Kenya,

... it would be dogmatic and mechanical to assert that neo-colonialism and underdevelopment must inevitably lead to revolutionary change in Kenya as a result of inevitable social and economic crisis.60

We turn now to a consideration of the intra-peripheral inequalities sustained, in part, by the same network of dependence which shapes domestic class formation.

The inequality of states in Africa: subimperialism and the political economy of regionalism

Africa has tried to mitigate its inheritance of dependence by the adoption of several international strategies: i) national non-alignment; ii) regional integration; iii) continental diplomatic interdependence; and iv) collective advocacy in international organisations and global conferences. ${ }^{61}$ However, continental cooperation and the myth of panAfrican equality are now threatened by the growth of interstate in- 
equalities in Africa. The discontinuity between economic dependence and diplomatic interdependence may be superseded by global economic dependence and continental diplomatic dependence, in an Africa dominated by a few leading continental states. The era of ideological blocs and conflicting factions may be replaced by regional hegemonies in which a few actors dominate regional and continental politics.

The trend towards inequality has been matched by the growth of new institutions in Africa, both regional and continental, economic and political, single- and multi-purpose. The mixed-actor system is more complex than either pre-colonial or colonial Africa and it has led to new patterns of dependence and interdependence both on the continent and between Africa and the World. ${ }^{62}$ The inherited dependence of African states has made them nationalistic both as individual nations and in association with other dependent actors in regional, continental, Third World or commodity organisations. Clearly individual parastatals do not act as equals in the transnational corporate world, but African advocaCY in UN special economic General Assemblies and in UNCTAD can improve terms of investment and technological transfer.

The dependence of African states on international trade varies; some countries produce fewer crops, export to fewer states and are less able to confxont the global econony. However, the mercantilist potential of most African states is limited ${ }^{63}$ unless they act as a group. Only in collectivities can African states hope to escape their inheritance of dependence, assert their own national interests, and establish a new pattern of interdependence. 64

A few, "semi-peripheral states" or "middle powers", may be able to grow or even develop, either by accident or invitation, but the majority will continue to be underdeveloping. ${ }^{65}$ For them, self-reliance may be an unavoidable, rather than a preferred strategy; it is difficult even for radical regimes to escape from their inheritance and situation. However, competition to achieve upward mobility is intense, leading to policies of neo-alignment and deference: "within a capitalist worldeconomy, all states cannot 'develop' simultaneously by definition, since the system functions by virtue of having unequal core and peripheral regions". 66

World order is now being maintained not only by the superpowers but also by "great powers" within particular continents or peripheries. A "sub-imperial" state is at the "centre" of the "periphery", a "client" which is able to exert dominance in one region. It is able to take advantage of the process of regional integration itself while at the same 
time remaining dependent on external actors. A sub-imperial state in Africa exerts a regional hegemony within the continent akin to the global dominance of an imperial power; it plays an important intermediate role in a "sphere of influence" while remaining subordinate itself to major external actors. ${ }^{67}$ Sub-imperial or "go-between" 68 states no longer have simple cooperative relations with metropolitan centres; old dependence ties are evolving into new and more complex forms of asymmetry. ${ }^{69}$ Nevertheless, it is clear that a group of leading African states have achieved both economic growth and military prowess because of their association with major world powers and interests. Dependence relations are not static; formal independence did enhance the opportunities for increased control and affluence for the new elites. Through bargaining and the exercise of limited state power they have been able to capture some of the benefits of economic growth for themselves, if not for the nation, as foreign interests have agreed to new terms. Yet, just as the high price for oil has enriched a few states, elites and companies, so new commodity arrangements and manufacturing opportunities will likely enhance only the already superior growth potentials of a few countries. In a world of scarcities and shortages no single New International Economic Order can advance all peoples. The "new interdependence" 70 is among rich states and peoples; it is by definition an exclusive and pervasive system which further condemns the "super-poor" Fourth World states. 71

The rhetorical equality of African states and leaders is being superseded by the real inequality of leaders based either on national or personal attributes, relations with extra-African interests, or by changes in the global economy. The emerging "consensus" in Africa may reflect the dominance of a few leading powers rather than a voluntary agreement on a continental "foreign policy". The renewed interest and influence of some Arab members of the OAU reflects their newly acquired international wealth and status. ${ }^{72}$ Africa, the largest regional grouping in terms of size and numbers of members, contains the most landlocked and least-developed states. These also tend to be the most dependent on a few exports to a few states and to be those most seriously affected by the energy crisis; they will also be most vulnerable to drought and the new politics of food. Africa also includes several exporters of oil (Libya, Algeria, Nigeria, Angola and Gabon) and of other "strategic" commodities such as copper (Zambia and Zaire), uranium (Niger, Gabon and South Africa), phosphates (Morocco) and bauxite (Guinea). Over time, the development prospects and achievements of these two groupings have diverged, leading to new continental inequalities. 
Further, the larger and more affluent states have been subject to most external diplomatic and corporate pressures to be "open" to investment and to a "sub-imperial" role. The emerging Pax Africana, nf a few superordinate African states acting in their own and non-African interests, is one result of the shared interests of African and foreign elites in the parastatal association. In Africa's return to relations of realpolitik, leadership will be the responsibility of a few states with large populations and/or significant mineral resources (Nigeria, Zaire, Algeria, Angola, Zambia, Libya and Botswana), or states with important administrative or industrial potential based on a history of collaboration (Kenya, Ivory Coast, Egypt, Senegal). South Africa is the only state in Africa with a mix of these characteristics.

The remaining states are primarily producers of a limited range of agricultural commodities. They may be able to become self-reliant and isolated; but they are more likely to remain dependent, not only on the major world traders but also on Africa's leading states. The emergent "middle powers" of Africa are becoming significant economic and diplomatic centres of the continent. ${ }^{73}$ In an era of superpower withdrawal, their intermediary role serves both corporate and strategic foreign interests. The new balance of power in Africa is not among pre-colonial kingdoms but among a group of dominant continental states, whose permissiveness towards foreign demands also serves to advance non-African interests. The uneven development of states in one region cuts across Amin's proposed typology of regions in Africa: there are greater differences within rather than between regions. ${ }^{74}$ As Amin himself notes there are increasing inequalities among African states over time: "the colonial trade necessarily gave rise to a polarisation of dependent peripheral development at the regional level".75

The "feudal" 76 nature of the contemporaxy international system has been chaxacterised by Hymer as analogous to the global structure of multinational corporations. Given the Law of Increasing Firm Size, the concentration of production and decision-making condemns most African states to a perpetual peripheral status. Some states, however, may achieve the status of intermediary, regional headquarters; regional offices, skills and markets may be concentrated in a few African capitals:

... a regime of North Atlantic Multinational Corporations would tend to produce a hierarchical division of labour between geographical regions corresponding to the vertical division of labour within the firm. It would tend to centralize high-level decision-making occupations in a few large cities in the advanced countries, surrounded by a number of regional sub-capitals, and confine the rest of the world to lower levels of activity and income, $i . e .$, to the status of towns and villages in the new Imperial system.77 
Interstate inequality in Africa is related to the emergence of regional spheres of influence on the continent.

The leading states of Africa are those most permissive towards international capitalism; they are characterised by a significant amount of external investment, collaborative parastatal institutions, dependence on regional exchange, and a trend towards domestic inequalities. Yet despite the problem of political order, they receive support from foreign investment and assistance agencies and are encouraged to play an intermediary role between the centre and the periphery. ${ }^{78}$ However, their semi-peripheral status leads to ambivalence and opposition, especially from states in their region who are dependent both on the semi-peripheral as well as the core states.

Regional integration may be either a voluniary or a coercive process; cooperative arrangements in Africa to date have been largely based on consensus, but regional exchange is now becoming an imperative for the manufacturing centres of Afxica. Increasingly, therefore, regional cooperation may come to reflect the interests of national and foreign elites in a few African states and capitals. ${ }^{79}$ It may perpetuate the uneven development of Africa rather than advance continental development.

Regional integration in Africa was first practised by colonial and settlex interests to increase administrative efficiency and economic opportunities. In contemporary Africa it has been widely advocated as both a path to peace and as a strategy for development. However, the continued incidence of regional conflict and the perpetuation of regional decay lead to scepticism about its inevitable efficacy. Although regional organisations in both East, West and Southern Africa have adapted to the impact of decolonisation they are now threatened by a "new nationalism" based on the uneven distribution of gains from economic cooperation. The major beneficiaries from the East African community, the Entente and the Southern African Customs Union have been the leading manufacturing and service centres of the regions--Kenya, Ivory Coast and South Africa, respectively, or rather the industrial complexes of Nairobi, Abiajan and the Witwatersrand. ${ }^{80}$ The fluidity of regional organisations in Africa is partially due to the maldistribution of industrial plant, infrastructure and services. African states attempt to establish new organisations to avoid African dominance as well as global hegemony.

Uneven development in African regional organisations has led to institutional tensions and decay rather than to conflict-resolution 
and economic development. A small group of African "middle powers" has advanced both national and foreign interests by the establishment of regional hegemonies permissive towards external investment and diplomacy. Foreign corporations and government agencies have encouraged regional cooperation by concentrating investment and aid in regional institutions. Regional markets, exchange and services advance growth and insulate investment from nationalisation and instability.

The collaboration between elites in Africa's middle powers and foreign actors advances both their interests; but it leads to regional inequalities and continued dependence. Regional integration is not always an escape from Africa's inheritance of subordination; rather, regional hegemonies may promote both its underdevelopment and its disunity. Regional integration in Africa is unlikely to produce selfreliance or integrated economies when some of its major advocates are foreign actors or collaborationist elites. Regional integration may not advance disengagement from the global economy; rather it may lead to the establishment of regional spheres of influence serving the interests of a few African and external states and elites. The master-plan of the Economic Commission for Africa (ECA) to create five sub-regions on the continent may further legitimise such sub-imperialism. The "second scramble" for Africa is not among colonial powers but among African states, each of which is significantly affected by external interests.

Independence in Africa has increased, rather than limited, economic dependence; economic growth has also declined and become more uneven. 81 Most African states have very open economies and have been rather uncritical in their acceptance of corporate plans and activities. The emergence of internal and interstate inequalities in Africa is one result of development plans based on the parastatal strategy and association with external interests. Decolonisation may not have change Africa's essential dependence on the international political economy. It has, however, made the relationships of dependence more complex and fluid. ${ }^{82}$ Some African states and elites can exploit the overall relationship of dependence, thus furthering the underdevelopment and inequalities of the continent.

So far in this essay we have examined the impact of dependence and underdevelopment in Africa at several levels. However, there are also examples on the continent of attempts to avoid the problems of both class formation and external dominance, especially among a few truly peripheral states. We turn, in conclusion, to their problems and prospects. Such states have declined to have the character of their politcal economies determined for them by external interests and they have 
largely rejected the legacy of "deformed development" 83 left by the colonial powers. Instead of playing an international role dictated by the logic of global exchange and comparative advantage they have sought to determine their own priorities and to enhance their own potential for autonomy and development. ${ }^{84}$ But despite the emergence and assistance of industrialised socialist states, progress towards socialism in Africa has been problematic because of the established global hierarchy. Selfreliance is by definition elusive in a complex world system of unequal state and non-state actors. 85

\section{Development strategies for the African periphery}

The formulation and implementation of strategies for development in the states comprising the African periphery is a problematic and sometimes hazardous exercise. Our analysis of the international and internal structures and mechanisms of dependence is conducive, we hope, to the creation of an awareness of the complex relationships involved in the entrenchment of dependent, unbalanced growth on the continent. The simultaneous confrontation of both external linkages and internal inequalities needed as a pre-requisite for development is a difficult and demanding process; one which is further complicated by sub-imperial hegemonies on the continent. In our analysis of the potential prospects for the African periphery we can hope, at least, to avoid the pitfall of prescribing panaceas which fail to take account of the internal and external exigencies of the political economy of dependence. ${ }^{86}$

Whilst recognizing that the internal, collective realization of human potential is not necessarily concomitant with the growth of autonomy in the exploitation and deployment of natural resources, 87 it may be constructive to outline the (limited) parameters of 'choice' before decision makers or ruling classes in peripheral states. ${ }^{88}$ Firstly, 89 such states may simply not develop but rather stagnate or even decay; spurned by parastatal associations with international capitalism, and possessing neither resources nor the means to exploit them, the "primitive community mode" 90 of production may continue to predominate. A second mode is that of total reliance on external capital, technology, tastes, expertise and markets; where 'development' is restricted to the ranks of the urban political, administrative, and industrial elites together with rural landlords and a small, skilled 'labour aristocracy'. ${ }^{91}$ Here, strategies for 'development' would be limited to campaigning for an increased scale of corporate operations. Finally we posit the alternative of the independent exploitation of local resources, or 
at most some intra-peripheral cooperation (excluding those relations characteristic of the other two groups). This necessarily entails a postponement of immediate (or even longer-term) material elite privileges, together with prolonged mass austerity necessitating considerable ideological tools of motivation along with the provision of collective, welfare goods and services.

clearly the framing of these three 'alternatives' is predicated upon a basic assumption, common to most 'western' analysis, of development as a linear process culminating in a capital-intensive, industrialized utopia. ${ }^{92}$ Interestingly, the dialectical-materialist approach propounded by orthodox Marxist-Leninists embodies a basically similar classification of options. ${ }^{93}$ In his comprehensive analysis of soviet Third World scholarship Kulski notes this typical tripartite classification of new states according to their likely progress towards socialism. Complicity with "imperialist exploiters", 94 modernization with "the broad participation of the national bourgeoisie", 95 and the adoption of "non-capitalist development" 96 are seen to differentiate the potential of African states. However, this classification is somewhat flexible: "The door to Moscow is closed to none of them", 97 which tends to support Wilson's thesis that considerations of "national security" form a continuous tenet of Soviet policy toward Africa. ${ }^{98}$

The three types of political economy which Kulski asserts are distinguished by soviet scholars may be compared to our earlier categories of state capitalism and state socialism. The "complicity" type is quite compatible with the former while the "participatory" political economy is similar to the latter. We did not include a "noncapitalist" category ourselves, primarily because this strategy would not appear to be a viable popular option for most African states in an essentially capitalist and competitive world economy. Moreover, even if a group of African leaders successfully overcame their inheritance of political, economic and social dependence, the logic of contemporary international relations mitigates against autonomy and self-reliance. Indeed, given the impossibility of autarky in the present world order the goal of most states is a balanced interdependence rather than a unequal dependence.

Clearly, the possibilities of non-capitalist development are aided by the prospects of increased exchange with more industrialised socialist states, but such interaction is not necessarily characterised by dependence. To be sure, socialist economies make different demands of the global economy and do not create the same imperatives for foreign 
exchange as do capitalist states and corporations. Nevertheless, we remain cautious about equating non-capitalist development with integration in the emerging socialist 'world system'. 99 Moreover, the tensions between nonalignment and socialist integration need to be examined before non-capitalist development is prescribed as the only alternative to state capitalism/complicity, or state socialism/participatory. In particular, the prospects of PanAfrican cooreration, "collective selfreliance", 100 and intraperipheral exchange all need to be carefully reviewed; the sophisticated strategy of the Andean pact might be instructive as a non-doctrinaire approach to regional development. 101

Parallels may also be drawn between the 'concrete' barriers to balanced development posed by the operation of international monopoly capital, and the ideological monopoly which tends to be arrogated at times by some soviet theoreticians. The one pre-empts the local formulation of a strategy by which development may be pursued, whereas the latter claims to be the sole vehicle whereby the exploitative results of imperialism can be thrown off. 102

A somewhat less dogmatic (although similarly naive) alternative strategy to non-capitalist development is that of "intermediate technology" as prosletyzed by Schumacher. ${ }^{103}$ He suggests that the technology of "production by the masses" is the only feasible strategy for the evolution of a process of development whose

... roots lie outside the economic sphere, in education, organization, discipline and, beyond that, in political independence and a national consciousness of self-reliance. 104

This prospect is a deceptively attractive one, especially as it involves not even the degree of sacrifice on the part of the "maldeveloped" countries called for in the crusading Mankind at the Turning Point. 105

Non-capitalist development, deploying intermediate technology, may be criticized as a strategy of "non-development" for the African periphery which might entrench the present international and internal inequalities rather than ameliorate them. If the consensus expressed in Sandbrook and Cohen's collection as to the progress of class formation in Africa is correct, then we may conclude that a likely compromise for the periphery is short-term collusion with external interests, with the long-term prospect of popular demands for control over the benefits of a presently incipient economic base. If Ake's analysis of the persistence of tribalism and regionalism and a fear of self-reliance 106 is accepted, however, the prognosis for the alleviation of internal inequalities fostered by external linkages of dependence is less hopeful. Again we must stress the crucial importance of the nature of evolution 
of the state in Africa. It is against this background that the potential for class formation and action must be assessed, and strategies for development proposed (see section on The political economy of the state in Africa).

As opposed to the macro-regional analysis of the club of Rome, we note that Africa presently contains a rich variety of political economies reflecting diverse inheritances, resources, ideologies and potentials. Its established and emerging inequalities require appropriate strategies to achieve development with equality for growth with redistribution?:). 107 Africa itself has to begin to choose between state capitalism, state socialism and non-capitalist development whilst recognizing that the choices are neither clear nor readily attainable because of established and attractive internal-external 1inkages. The present ruling classes on the continent will likely resist any demands for a radical restructuring of Africa's political economies and so the transformation to more enlightened and equitable development strategies may yet require a revolution. Given the pervasiveness of neocolonial structures in Africa the transition from national dependence to interdependence is likely to be difficult and prrtracted because the established modes of cooperation between national and international elites are quite well entrenched. Given internal and international inequalities in Africa, the isolation of targets for action must not lead to deterministic complacence as to their likely attainment.

\section{NOTES}

1. Richard Harris "Preface" in his collection on The political economy of Africa (Cambridge, Mass.: Schenkman, 1975) vii. This approach is also advocated by Immanuel wallerstein:

... to understand the internal class contradictions and political struggles of a particular state, we must first situate it in the world-economy. We can then understand the ways in which various political and cultural thrusts may be efforts to alter or preserve a position within this world-economy which is to the advantage or disadvantage of particular groups located within a particular state.

Immanuel Wallerstein "The present state of the debate on world inequality" in his collection World inequality: origins and perspectives on the world system (Montreal: Black Rose, 1975) 16.

2. For one attempt to do this see Timothy M. Shaw "African states and international stratification: the adaptive foreign policy of Tanzania" in $\mathrm{K}$. Ingham (ed) The foreign relations of African states (London: Butterworth, 1974. Colston paper number 25) 213-136.

3. For a brief historial introduction to the political economy of Africa see Timothy $M$. Shaw "The actors in African international politics" in Kenneth $A$. Heard and Timothy $M$. Shaw (eds) Politics of Africa: dependence and development (London: Longman and Dalhousie University Press, 1977). 
4. Richard Harris reviews the contributions of these scholars, as well as those of Andre Gunder Frank and Romano Ledda in his "The political economy of Africa: underdevelopment or revolution" in his the political economy of Africa 1-47. See also Stanley J. Hilderbrand "A new paradigm in African Studies" Ufar amu 5(2), 1974, 3-19, and Bruce J. Berman "Clientelism and neocolonialism: centre-periphery relations and political development in African states" Studies in Contemporary International Development 9, 1974, 3-25.

5. On the need to define the state see John $S$. Saul "Socialism in one country: Tanzania" in Giovanni Arrighi and John S. Saul Essays on the political economy of Africa (New York: Monthly Review, 1973) 237-335 and "The state in post-colonial societies: Tanzania" in Ralph Miliband and John Saville (eds) The Socialist Register 1974 (London: Merlin, 1974) 349-372. See also Hamza Alavi "The state in post-colonial societies - Pakistan and Bangladesh" New Left Review 74, July-August 1972, 59-82, Jonathan Fast "Imperialism and bourgeois dictatorship in the Phillipines" New Left Review 78, MarchApril 1973, 69-96, and Fred Halliday "Saudi Arabia: bonanza and repression" New Left Review 80, July-August 1973, 3-26.

6. Harris "The political economy of Africa" 30. See also Barbara Callaway "The political economy of Nigeria" in Harris (ed) The political economy of Africa 95-135.

7. For useful theoretical works on underdevelopment see inter alia Andre Gunder Frank "The development of underdevelopment", "Economic dependence, class structure and underdevelopment policy" and "Sociology of development and underdevelopment of sociology" in James D. Cockroft, Andre Gunder Frank and Dale L. Johnson (eds) Dependence and underdevelopment: Latin America's political economy (New York: Anchor, 1972) 3-45 and 321-397 and Johan Galtung "A structural theory of imperialism" Journal of Peace Research 2, 1971, 81-117. See also Philip J. O'Brien "A critique of Latin American theories of dependency" in Ivar Oxaal et al. (eds) Beyond the sociology of development: economy and society in Latin America and Africa

(London: Routledge \& Kegan Paul, 1975) 7-27, Aidan Foster-Carter "Neo-Marxist approaches to development and underdevelopment" in Emmanuel de Kadt and Gavin Williams (eds) Sociology and development (London: Tavistock, 1974) 67-105, Fernando Henrique Cardoso "Dependency and development in Latin America" New Left Review 74, JulyAugust 1972, 83-95 and Lawrence R. Alschuler "Satellization and stagnation in Latin America" International studies Quarterly 20(1), March 1976, 39-82.

8. See R. Cranford Pratt "Foreign-policy issues and the emergence of socialism in Tanzania 1961-8" International Journal 30(3), summer 1975, 448; see also his the critical phase in Tanzania, 1945-68: Nyerere and the emergence of a socialist strategy (Cambridge: University Press, 1975).

9. For persuasive analyses of Africa's underdevelopment see René Dumont False start in Africa (London: Sphere, 1968) and Basil Davidson Can Africa survive? Arguments against growth without development (Boston: Little Brown, 1974).

10. See Nelson Kasfir The shrinking political arena: participation and ethnicity in African politics, with a case study of Uganda (Berkeley: University of California Press, 1976) 14-27.

11. Cf. recent writings in the tradition of the established paradigm, for example, Arthur Jay Klinghoffer "Modernisation and political development in Africa" Journal of Modern African Studies 11(1), March 1973, 1-19 and Leslie Rubin and Brian Weinstein Introduction to African politics: a continental approach (New York: Praeger, 1974). 
12. For a bitter attack on "The pitfalls of national consciousness" see Frantz Fanon The wretched of the earth (Harmondsworth: Penguin, 1967).

13. See Jan J. Jorgensen "Multinational corporations and the indigenization of the Kenyan economy" in Carl Widstrand (ed) Multinational firms in Africa (Uppsala: Scandinavian Institute of African Studies, 1975) 143-177.

14. Reginald H. Green "Political independence and the national economy: an essay on the political economy of decolonisation" in Christopher Allen and R.W. Johnston (eds) African perspectives: papers in the history, politics and economics of Africa presented to Thomas Hodgkin (Cambridge: University Press, 1970) 275-276. See also his "The peripheral African economy and the MNC" in Carl Widstrand (ed) Multinational firms in Africa 92-124 and "Tanzanian goals, strategies, results: notes toward an interim assessment" Seminar on Socialist development in Tanzania since 1967, Toronto, April 1976.

15. For an earlier attempt to sustain this distinction see Timothy $M$. Shaw "The political economy of African international relations" Issue 5(4), Winter 1975, 29-38. For a commendable, but uneven, novel attempt to examine Africa's political economy see Henry.Bretton Power and politics in Africa (Chicago: Aldine, 1973).

16. Cf. Samir Amin "Underdevelopment and dependence in black Africa origins and contemporary forms" Journal of Modern African Studies 10(4), December 1972, 503-525.

17. Fanon describes this relationship well:

The national bourgeoisie steps into the shoes of the former European settlement ... the national middle class discovers its historic mission: that of intermediary ... it's mission has nothing to do with transforming the nation; it consists, prosaically, of being the transmission line between the nation and a capitalism, rampant though camouflaged, which today puts on the masque of neo-colonialism. The national bourgeoisie will be quite content with the role of the western bourgeoisie's business agent, and it will play its part without any complexes in a most dignified manner.

(The wretched of the earth 122).

18. Immanuel Wallerstein "Africa in a capitalist world" Issue 3(3), Fall 1973, 9. See also his "Class and class conflict in contemporary Africa" Canadian Journal of African Studies 7(3), 375-380, reprinted in Monthly Review 26(9), February 1975, 34-42.

19. T. dos Santos "The crisis of development theory and the problem of dependence in Latin America" in Henry Bernstein (ed) Underdevelopment and development: the third world today (Harmondsworth: Penguin, 1973) 79 .

20. On the dangers of a haphazard, premature advance to state socialism, and for an insightful comparative study of the state and class formation in Africa, see Miles D. Wolpin "Dependency and conservative militarism in Mali" Journal of Modern African Studies 13(4), December 1975, 585-620, especially 588-612. Also on the dilemmas of economic nationalism see Theodore $\mathrm{H}$. Moran Multinational corporations and the politics of dependence: copper in Chile (Princeton: Princeton University Press, 1974).

21. On the problems of advancing beyond state socialism in Tanzania see Issa G. Shivji Class struggles in Tanzania (London: Heinemann, 1976), 
22. John S. Saul "The political aspects of economic dependence" in Dharam P. Ghai (ed) Economic independence in Africa (Nairobi: East African Literature Bureau, 1973) 135 .

23. The debate over the role and impact of parastatals is most advanced in the case of Tanzania. See inter alia "Special issue on the political economy of parastatals" Easterna African Law Review 5(1-2), 1972, John Loxley and John S. Saul "Multinationals, workers and parastatals in Tanzania" Review of African Political Economy 2, January-April 1975, 54-88, Brian van Arkadie "Development of the state sector and economic independence" in Ghai (ed) Economic independence in Africa 88-122, Justinian Rweyemamu et al. (eds) Towards socialist planning (Dar es Salaam: Tanzania Publishing House, 1972), I.G. Shivji "Capitalism unlimited: public corporations in partnership with multinational corporations" Africa Review 3(3), 1973, $359-$ 382 , and "Special issue on performance in the management of public enterprises in Tanzania" African Review 5(2), 1975, 119-234. See also Justinian Rweyemamu Underdevelopment and industrialisation in Tanzania (Nairobi: OuP, 1973), essays in Lionel Cliffe and John S. Saul (eds) Socialism in Tanzania, Two Volumes (Nairobi: East African Publishing House, 1972 and 1973), and several papers presented at the Seminar on Socialist development in Tanzania since 1967.

24. See Norman Girvan "Economic nationalists $v$. multinational corporations: revolutionary or evolutionary change" in widstrand (ed) Multinational firms in Africa 25-56.

25. On the varieties of corporate-parastatal axrangements see Ann Seidman "Multinational corporations and economic independence in African Social Research 19, June 1975, 739-750, "Old motives, new methods: foreign enterprise in Africa today" in Allen and Johnson (eds) African perspectives 251-272 and Planning for development in sub-Saharan Africa (New York: Praeger, 1974) and Widstrand (ed) Multinational firms in Africa.

26. On the corporation in the Third World see inter alia Louis Turner Multinational companies and the Third World (London: Allen Lane, 1973) and Richard J. Barnet and Ronald E. Muller Global reach: the power of multinational corporations (New York: Simon and Schuster, 1975).

27. See especially colin Leys Underdevelopment in Kenya: the political economy of neocolonialism (Berkeley: University of California Press, 1974) and Steven Langdon "Multinational corporations, taste transfer and underdevelopment: a case study from Kenya" Review of African Political Economy 2, January-April 1975, 12-35.

28. See Timothy M. Shaw Dependence and underdevelopment: the development and foreign policies of Zambia (Athens: Ohio University, papers in International Studies, Africa Series Number 28, 1976) and

Sheridan Johns "Parastatal bodies in Zambia: problems and prospects" in Heide and Udo Ennst Simonis (eds) Socio-economic development in dual economies: the example of Zambia (Munich: Weltform Verlag for African Studies Institute, 1971) 61-94 and "State capitalism in Zambia: the evolution of the parastatal sector" African Studies Association, San Francisco, October 1975.

29. See Clive $Y$. Thomas "Industrialization and the transformation of Africa: an alternative to MNC expansion" in Widstrand (ed) Multinational firms in Africa 325-360.

30. See Dharam P. Ghai "Introduction" in his collection on Economic independence in Africa xiii. 
31. Dharam P. Ghai "Concepts and strategies of economic independence" Journal of Moderna African Studies 11(1), March 1973, 35. See also his "Perspectives on future economic prospects and problems in Africa" in Jagdish N. Bhagwati (ed) Economics and world order (New York: Macmillan, 1972) 257-286.

32. See Samir Amin Neocolonialism in West Africa (Harmondsworth: Penguin, 1973), Ann Seidman Comparative development strategies in West Africa (Nairobi: East African Publishing House, 1972) and Reginald H. Green and Ann seidman Unity or poverty? The economics of PanAfricanism (Harmondsworth: Penguin, 1968).

33. See Reginald H. Green "Petroleum prices and African development: retrenchment or reassessment?" International Journal 30(3), Summer 1975, 391-405, and Ernest J. Wi Ison III "The energy crisis and African underdevelopment", and G.E. Emembelu and S.S. Pannu "Africa: oil and development" Africa Today 22(4), October-December 1975, 11-37 and $39-47$.

34. Seidman Planning for development in sub-Saharan Africa 55 . See also her "Changing theories of political economy in Africa" University of Zambia 1974 .

35. See Roger Murray "Militarism in Africa" New Left Review 38, JulyAugust 1966, 35-99 and Robin Murray "Underdevelopment, international firms and the international division of labour" in Towards a new world economy (Rotterdam: University Press, 1972) 160-247.

36. See, for instance, Ann Seidman "The distorted growth of importsubstitution industry: the Zambian case" Journal of Modern African Studies 12(4), Decembex 1974, 601-631.

37. Immanuel Wallerstein "Dependence in an interdependent world: the limited possibilities of transformation within the capitalist world economy" African Studies Review $17(1)$, April 1974, 22.

38. See, for example, Leslie L. Rood "Foreign investment in African manufacturing" Journal of Modern African Studies 13(1), March 1975, 19-34. For an "Official" perspective on the most "suitable" African states see "The Department of State News Release: us Economic relations with Africa" New York, 18 February 1976.

39. See Timothy M. Shaw "Discontinuities and inequalities in African international politics" International Journal 30(3), Summer 1975, $369-390$.

40. CE. the more optimistic view of the possibilities of "counterdependence" in Ali $A$. Mazrui "The new interdependence: from hiexarchy to symmetry" in Guy F. Exb and Valerina Kallab (eds) Beyond dependency: the developing world speaks out (Washington: Overseas Development Council, 1975) 38-54. See also I. William zartman "Europe and Africa: decolonisation or dependency?" Foreign Affairs 54(2), January 1976, 325-343.

41. See Osvaldo Sunkel "Transnational capitalism and national disintegration in Latin America" Social and Economic Studies 22(1), March $1973,132-176$.

42. See, for example, Martin Godfrey and Steven Langdon "Partners in underdevelopment? The transnationalisation thesis in a Kenyan context" Canadian Association of African Studies, February 1975 and Steven Langdon "Technology transfer by multinational corporations in Africa: effects on the economy" African Studies Association San Francisco, October 1975. 
43. Godfrey and Langdon "Partners in underdevelopment?" 15.

44. Jorgensen "Multinational corporations and the indigenization of the Kenyan economy" 167-170.

45. See Robert I. Curry Jr. and Donald Rothchild "On economic bargaining between African governments and multi-national companies" Journal of Modern African Studies 12(2), June 1974, 173-191.

46. Wallerstein "Class and class confict in contemporary Africa" 380 . See also his "The range of choice: constraints on the policies of governments of contemporary African independent states" in Michael F. Lofchie (ed) The state of the nations (Berkeley: University of California Press, 1971) 19-33.

47. On the case of Zambia see Timothy M. Shaw "Zambia: dependence and underdevelopment" Canadian Journal of African Studies 10(2), 1976.

48. Leys Underdevelopment in Kenya 11. See also Widstrand (ed) Multinational firms in Africa, passim.

49. See Jorgensen "Multinational corporations and the indigenization of the Kenyan economy" especially $152-56$ and 167-170.

50. See, for instance, Timothy M. Shaw and Agrippah T. Mugomba "The political economy of regional detente: Zambia and southern Africa" Journal of African Studies, 1976 and "Zambia: dependence and detente" in John Seiler (ed) Southern Africa since the Portuguese coup (forthcoming).

51. According to Fanon, the "under-developed middle class" of Africa is neither authentic nor really a national bourgeoisie: it is

... not engaged in production, nor in invention, nor building, nor labour; it is completely canalized into activities of the intermediary type. Its innermost vocation seems to be to keep in the running and to be part of the racket.

(The wretched of the earth 120). See also his Black skin: white masks (London: Paladin, 1970), A dying colonialism (Harmondsworth: Pelican, 1970) and Toward the African revolution (Harmondsworth: Pelican, 1970).

52. Davidson Can Africa Survive? 85.

53. See Shaw "The actors in African international politics".

54. Julius K. Nyerere "The rational choice" in his Freedom and development: uhuru na maendeleo (Dar es Salaam: Oup, 1973) 384.

55. See Philip Foster and Aristide R. Zolberg (eds) Ghana and the Ivory Coast: perspectives on modernisation (Chicago: University of Chicago Press, 1971), Jon Woronoff West African wager: Houphouet versus Nkrumah (Metuchen: Scarecrow, 1972) and Amin Neocolonialism in West Africa.

56. See Arrighi and Saul "International corporations, labor aristocracies and economic development in tropical Africa" in their Essays on the political economy of Africa 141 .

57. See Richard Sandbrook and Robin Cohen "Workers and progressive change in underdeveloped countries" in their collection on the development of an African working class: studies in class formation and action (Toronto: University of Toronto Press, 1971) 1-9 and Issa Shivji "Peasants and class alliances" Review of African Political Economy 3, May-October 1971, 10-18. See also the analysis of "discordant sections" in the political class of Kenya in Richard Sandbrook Proletarians and African capitalism: the Kenyan case 1960-1972 (London: Cambridge University Press, 1975) 3-27, especialIy 13 . 
58. John S. Saul "The 'labour aristocracy' thesis reconsidered" in Sandbrook and cohen (eds) The development of an African working class 304 and 305. See also V.L. Allen "The meaning of the working class in Africa" Journal of Modern African Studies 10(2), July 1972, 169189 and Robin Cohen "Class in Africa: analytical problems and perspectives" in Ralph Miliband and John Saville (eds) The Socialist Registex 1972 (London: Merlin, 1972) 231-255.

59. Sandbrook and cohen "Workers and progressive change in underdeveloped countries" 6 .

60. Leys Underdevelopment in Kenya 274.

61. On these see, inter alia, John J. Okumu "The place of African states in international relations" in August Schou and Arne Olav Brundtland (eds) Small states in international relations (Stockholm: Almqvist \& Wikseli, 1971. Nobel Symposium 17) 147-155 and Thomas Hovet "Effect of the African group of states on the behaviour of the United Nations" in Yassin El-Ayouty and Hugh C. Brooks (eds) Africa and international organization (The Hague, Nijhoff, 1974) $11-17$.

62. See Shaw "Discontinuities and inequalities in African international politics".

63. See the review of alternative types of political economy by Robert Gilpin "Three models of the future" International Organization 29 (1), Winter 1975, 37-60 and "The political economy of the multinational corporation: three contrasting perspectives" American Political Science Review 70(1), March 1976, 184-191.

64. See Donald Rothchild and Robert I. Curry "Beyond the nation-state: the political economy of regionalism" American Political Science Association San Francisco, September 1975 and Ghai "Concepts and strategies of economic independence".

65. See Wallerstein "Dependence in an interdependent world".

66. Wallerstein "The present state of the debate on world inequality" 23.

67. See Timothy M. Shaw "Regional cooperation and conflict in Africa" International Journal 30(4), Autumn 1975, 671-688.

68. See Galtung "A structural theory of imperialism" 104-105.

69. See Timothy M. Shaw "International stratification in Africa: subimperialism in eastern and southern Africa" International Political Science Association Edinburgh, August 1976.

70. Cf. Mazxui "The new interdependence: from hierarchy to symmetry". For other "post-dependencia" analyses of new actors, complexities and loyalties in world politics which, the authors claim, necessitate more sophisticated modes of analysis see Yale H. Ferguson "Through glasses darkly: an assessment of various theoretical. approaches to inter-American relations" and Adalberto José Pinelo "Latin American perceptions and responses to American policy on multinational corporations" International Studies Association Toronto, February 1976.

71. See Agrippah T. Mugomba "The foreign policy of the 'super poor': neutrality and nonalignment in contemporary international politics" Centre for Foreign Policy Studies, Dalhousie University, April 1976.

72. See, for instance, Timothy M. Shaw "Oil, Israel and the OAU: an introduction to the political economy of energy in southern Africa" Africa Today $23(1)$, January/March 1976, 15-26. 
73. See Timothy M. Shaw "The development of international systems in Africa" Third International Congress of Africanists Addis Ababa, December 1973 .

74. See Timothy M. Shaw "Regional cooperation and conflict in Africa" International Journal 30(4), Autumn 1975, 671-688.

75. Amin "Underdevelopment and dependence in black Afxica" 523. See also Eva Senghaas-Knobloch "The internationalization of capital and the process of underdevelopment. The case of black Africa" Journal of Peace Research 12(4), 1975, 275-292.

76. Robin Jenkins Exploitation: the world power structure and the inequality of nations (London: MacGibbon \& Kee, 1970) 84.

77. Stephen Hymer "The multinational corporation and the law of uneven development" in Bhagwati (ed) Economics and world order 114.

78. On the diversity of both domestic and foreign actors involved in the making of national and foreign policy in zambia, for instance, see Timothy M. Shaw "The foreign policy system of Zambia" African Studies Review 19(1), 1976, 31-66.

79. On Zambia's ambivalence towards regional confrontation and integration see Timothy $M$. Shaw "The foreign policy of Zambia: ideology and interests" Journal of Modern African Studies 14(1), March 1976, 79-105.

80. See Shaw "Regional cooperation and conflict" and "International stratification in Africa".

81. See Ghai "Perspectives on future economic problems and prospects in Africa" and "Africa, the Third World and the strategy for international development" in Mazrui and Patel (eds) Africa in World Affaixs 235-256.

82. See Seidman "Multinational corporations and economic independence in Africa", and Henry Bretton "Patron-client relations: middle Africa and the powers" and "Direct foreign investment in Africa" General Learning Press, New York, 1971 and 1976.

83. Harris "The political economy of Africa" 13.

84. For a fascinating case study of disengagement from an (inter-) dependent world, that of Burma, see K.J. Holsti "The isolationist impulse in foreign policy" International Studies Association Toronto, February 1976.

85. On the complex relations among "maldeveloped"/"overdeveloped" states and poor countries, as well as on the need for new approaches and models, see K.J. Holsti "Underdevelopment and the 'gap' theory of international conflict" American Political Science Review 69(3), September 1975, 827-839.

86. See, for example, Reginal H. Green and Ann Seidman Unity or poverty: the economics of pan-Africanism (Harmondsworth: Penguin, 1968). The economics of large-scale production and marketing cannot be realised in the context of competing "national" comprador bourgeoisies so it is naive, albeit technically accurate, to assert that

The continental market is broad enough to absorb the products of planned industrial and agricultural growth. (p. 81)

87. See Sandbrook and Cohen "Workers and progressive change in underdeveloped countries" 1-9; note especially "a conception of development whose prime goal is social equality" (p.5). 
88. The notion of 'dependence' may itself be criticized for its stress on the fairly passive role of 'local'/peripheral actors in the face of a vibrant and aggressive western capitalism. To avoid new charges of paternalism we need to recognise the mutual interests of comprador groups and foreign actors.

89. These are ideal types. We recognise that elements of each may exist in all developing states.

90. Claude Ake "Explanatory notes on the political economy of Africa" Journal of Modern African Studies 14(1), Spring 1976, 1 .

91. For an interesting 'dialogue' on the validity of this concept see Adrian Peace "The Lagos proletariat: labour aristocrats or populist militants" and a response by Saul "The 'labour aristocracy' thesis in Sandbrook and Cohen (eds) The development of an African working class 281-302 and 303-310.

92. On the inadequacies of this "model", as well as why "maldevelopment" affords an explanation of why rich/poor gaps may not lead to violence between states see Holsti "Underdevelopment and the 'gap' theory of international conflict". The symbiotic linkages of comprador bourgeoisies with "overdeveloped" states reinforce the unlikelihood of interstate violence because of global inequalities.

93. See Jenkins "Images of the world system" in his Exploitation 73-81

94. W.W. Kulski The Soviet Union in World Affairs: a documented analysis 1964-1972 (Syracuse: Syracuse University Press, 1973) 161.

95. Ibid.

96. Ibid. "Noncapitalist" development in current Soviet parlance is seen as an intermediate and transitional phase rather than as alternative socio-economic structuring of the means of production. For a full discussion of the (rather narrow and uncritical) range of Soviet debate on this concept see Kulski The Soviet Union in world affairs 180-189. An exposition of the historical origins of this adaption of Marxist theory may be found in Edward $\mathrm{T}$. Wilson Russia and black Africa before World War II (New York: Holmes and Meier, 1974) 99-120. For a contemporary collection of Soviet authorship on "development" see Africa in Soviet Studies Annual 1972 (Moscow: Nauka, 1975); see especially V.N. Yakovtsevsky "MarxismLeninism on transitional measures conducive to socialism - the experience of the U.S.S.R." 22-33.

97. Kulski The Soviet Union in world affairs 162.

98. Wilson Russia and black Africa before World War II 269-280.

99. On the problems of involuntary and unequal regional integration among socialist as well as capitalist states see Richard A. Falk "Zone II as a world order construct" in James N. Rosenau, Vincent Davis, Maurice A. East (eds) The analysis of international politics (New York: Free Press, 1972) 187-206.

100. On this strategy see What now? Another development (Uppsala: Dag Hammarskjold Report, 1975) 70-87.

101. See W. Andrew Axline and Lynn K. Mytelka "Dependence and regional integration: a comparison of the Andean Group and CARICOM" International Studies Association Toronto, February 1976.

102. See V.D. Shchetinin cited in Kulski. The Soviet Union in world affairs:

Contemporary African social ideology is characterized above all by its inconclusiveness, by a variety of concepts, by inexact definitions, by inner contradictions, and by fluid boundaries between the various trends. (pp. 176-177) 
103. E.F. Schumacher Small is beautiful: economics as if people mattered (New York: Harper and Row, 1975).

104. Ibid, 204 .

105. Mihalo Mesarovic and Eduard Pestel Mankind at the turning point: the second report to the Club of Rome (New York: New American Library, 1976). This globally oriented study, reflecting the real concern of groups in the "developed" world over its exponentially increasing plunder of scarce resources, projects that an annual per capita aid yield of $\$ 3,000$ is needed to narrow the per capita gap down to 5 to 1 by the year 2025 (pp. 56-69).

106. See Ake "Explanatory notes on the political economy of Africa" 4-9.

107. Cf. Hollis Chenery et al. (eds) Redistribution with growth (London: OUP for IBRD and IDS, 1974). In many ways, this important collection constitutes the "official" aid donors' response to radical attacks on aid as imperialism. 
Józef Nowicki

NON-CAPITALIST AGRICULTURE AND DEVELOPMENT STRATEGY

Institutional framework

Non-capitalist development of agriculture in the less developed countries (hereafter abbreviated LDC) requires first of all an appropriate institutional framework, within which the development of the whole economy - agriculture including - can take place. It is then one of the most important preconditions for non-capitalist development.

It goes without saying that traditional community of LDC has a rigidly formed social structure based on the ownership of land being the basis of its economic and political power. Social relations existing in many LDC are quasi-feudalistic ones; there is no personal dependence of peasants on land owners, but they have similar economic obligations towards them; they have to supply them with a part of annual crop (usually about 50\%) and to provide them with free services; they are also persistently indebted with them. Besides, in numerous African countries the widespread tribe ownership is followed by serious impediment to development of modern agricultural methods. In many countries of Africa family bonds are also exceptionally strong. This imposes on every family member the duty of catering to the needs of a larger number of relatives, even those who have migrated to the towns. In other LDC women do not posess full rights of citizenship, which limits their participation in active economic, political and cultural life of their countries. A widespread system of land renting and very high interest rates upon private credit ${ }^{1}$ (often above 100\%) establish additional barriers to development of agriculture in LDC. A relatively small group of big landlords, owning an overwhelming part of arable land, keep economic control in their hands in close alliance with urban elites and foreign capital. They are then able to exercise an effective control over the peripheries sometimes more firmly than in colonial times ${ }^{2}$. Their power over the prepoderant part of the community is based on the unholy trinity which is hunger, unemployment and illiteracy.

This is the reason why profound institutional changes, which really would mean a social revolution, should be treated as preconditions for development, especially in agricultural sector of LDC. Those changes,. which have to precede and to accelerate an economic development of LDC, 
prove to be a prolonged and complex process. I shall touch here upon some of its aspects only, particularly those which - according to my opinion - have vital importance to development of agriculture in LDC along the non-capitalist path ${ }^{3}$.

As many examples have already proved, the only starting point of the above mentioned changes is the take over of political power by the group of people, who are really interested in socio-economic development. This would first of all mean to get rid of big landlords and foreign capital from political power in the country. The former can be deprived of it by taking away economic power from them through a comprehensive and radical land reform ${ }^{4}$. The activity of foreign capital, on the other hand, can be tolerated provided that it does not interfere in the internal policy of the country. It should switch its activities to economic cooperation and assistance and not to post-colonial exploitation.

No need saying that it is easy to formulate those conditions but their implementation is much more difficult. The answers to the question how those conditions could be completed must be different in different countries; they depend on the internal and external political factors which may be - and certainly are - different in particular countries concerned. One thing seems to be certain, however, and it is confirmed by experience of not only socialist countries: that implementation of those conditions clears the way to an advanced and balanced socioeconomic development of the country.

Change of the central government supplies inevitable conditions for changes at different levels of state administration which necessarily exercise a part of administrative power within the country. The reason is that it is hard to imagine an advanced development of national economy without direct participation of representatives of the community in decision-making at local levels. This refers in paxticular to the rural population which can actively cooperate in the development process e.g. through a well organized network of cooperatives ${ }^{5}$.

Thus, the main institutional change which must precede a real and active incorporation of agriculture into the process of non-capitalist sociomeconomic development is a broadly conceived land reform. At the minimum, it must include the following elements:

i) redistribution of land which is actually or potentially cultivable;

ii) abolishment of land renting; 


\section{iii) extention of irrigation projects;}

iv) liquidation of usury capital by seting up cheap cooperative credit facilities to the peasants;

v) introduction of professional training in multi-crop cultivation, in application of new seeds, natural and chemical fertilizers and pesticides.

The experience of both socialist and some non-socialist countries which have implemented such programmes demonstrates that their results achieved in the field of increasing both employment and agricultural production are clearly positive. One of them, but perhaps the most important for the further development, is the redistribution of income to the poorest strata of agricultural population. This has to be born in mind by every government of LDC in question which is engaged on land reform ${ }^{6}$. However, uncontrolled development of agriculture - even after the reform has been implemented - always gives priority to rich peasants who have an easier access to state and/or cooperative credit facilities, used very often for usury lending. They are also more inclined to assume risk connected with introduction of new crops, and/or fertilizers to undertake proper inputs for having two and more harvests per year and similar innovations which are followed by extention and intensification of their economic, social and political superiority. The example of the so called green revolution provides an excellent illustration of that point ${ }^{7}$. The effectiveness of counter - measures designed to stop this process depends upon its range and intensity on the one hand and upon the efficiency of governmental power and its good-will on the other.

In other words even successfully completed land reform on radical terms does not by itself get rid of the capitalist mode of production ${ }^{8}$; it does not even exclude the possibility of its further development if the government concerned will not be careful enough to block its way. on the other hand, however, such a land reform creates a sufficient number of self-sustained farms, which if properly supported by the government in the transitional period may successfully develop towards socialist oriented forms of production, i.e. cooperatives or even state farms.

An institutional reform of fundamental importance to improvement of agriculture is the development of a new pattern of education. In the long run it means development of primary education for all children at school age. In the short run, however, it has to emphasize the broad schemes of professional instruction programmes for the rural population, especially in technical improvements and methods of land cultivation. 
One may and should make use of students for this purpose who could perform an obligatory one-year of this kind of social service. By forming a kind of social teams of students it would be possible to teach peasants not only the difficult art of reading, writing and arithmetics but also instruct them on their rights to land which they cultivate, their place within the society, the right to protection by the government etc. As some examples indicate (e.g. Cuba or China) the effects of such a work could be unexpectedly positive. This is all the more important if we bear in mind that the number of adult illiterates in LDC was estimated at 760 million persons in 1970 compared with 700 million in $1969^{9}$.

In the long run the educational policy of government should aim at providing full primary education to all children at school age. The schools should be organized not only in the village, but for the village; it means that the curricula and the time of instruction should be more elastic, the teaching staff better qualified, better paid and closely attached to the local milieu. Particular attention should be paid to efficiency of education during the first 4 years of instruction because only in this way young people can be protected against the so called secondary illiteracy ${ }^{10}$.

The production of modern agriculture is market-oriented as distinguished from traditional agriculture which claims to be self-sufficient. Transition of self-sufficient or natural production through a gradual increase of market oriented part of agricultural production in LDC must be preceded by many additional, institutional changes which will facilitate and induce a redistribution of GNP. They include among others: expansion of transport network. (railways, roads, navigable rivers) which would bring producers closer to the urban markets, as well as a specific kind of marketing. This programme must be financed and directed by appropriate state agencies of the country; in combination with an increase of production and supply of industrial articles for peasants it will certainly speed up the growth of agricultural market oriented production. 11

Another important feature of institutional reforms in LDC is raising the work discipline which is a specific feature of a modern society, but which a majority of LDC are short of. This sometimes requires to break old-age habits which - if combined with malnutrition and extremely poor living and health conditions - results in an exceptionally low propensity to work. Public work programme, organized and financed by the government concerned might be one possible way to strengthen $i t$. One can imagine that combining such public work programmes with financing them 
(at least partially) by food supply organized by the employer could give positive effects. It could also be treated as a some sort of preparatory school "surplus" population to more efficient and better organised work on their own land or in their own workshops, as all fields of economic activity in modern society require greater intensity of work than the traditional one.

Undoubtedly, such reforms must be financed by the state budget. They thus require relatively large capital outlays which are in short supply in many countries, but which would be earned back very quickly as it can be demonstrated by quoting numerous examples. All the same, foreign assistance may become necessary, but it is not impossible to be obtained, provided it is based on principles accepted by economic cooperation of some IDC with socialist countries (e.g. Iraq, Iran, Algeria, Peru).

In addition to short supply of capital available to the government, capital is very often used in an inefficient way. Besides, so far only a small percentage of it is being spent for development of agriculture, especially of small farms. It cannot also be forgotten that big farmers are usually favoured by the tax scale and by more positive (or less negative) ratio of agricultural to industrial prices. It is an additional argument for necessity of governmental control over distribution of the above mentioned advantages following the institutional changes already discussed among the respective population groups in agricultural sector of LDC. This has a vital importance for the rate of further development of agriculture, for a blockage of the emergence of new capitalist farms and for the creation of an economic and social basis for a socialist oriented path of development.

It has been generally accepted and proved that planning of national economy may be very helpful in that activity of government. Even more; it cannot be denied that without planning it would be impossible tc complete this sort of reform. The only question is, what kind of planning is the most efficient one at the stage of entering the transitional period. Without getting into details it seems to be pretty obvious that it has to be some kind of indirect planning. ${ }^{12}$ Such a plan, however, has to be very carefully worked out and strictly executed if it is going to benefit to development of LDC; otherwise it will be pure formality, as it is often the case. 


\section{Industry and agriculture}

There is a widely accepted view that an acceleration of socio-economic development of LDC may be accomplished exclusively through a rapid industrialization. In support of this thesis some examples are quoted from the experiences of both the most advanced and highly industrialized socialist countries. When developing all the branches of industry, the last ones are also trying to close the gap between them and the former group of countries. Under these circumstances, industrialization of LDC is regarded by many economists as the only way to abolish mass unemployment (especially disquised unemployment in agriculture), inefficient use of existing capital equipment, technical and social backwardness, malnutrition and a chronical shortage of accumulation. This pattern of development is also considered as a road to independence from foreign assistance which often entails informal but strong economic dependence upon the donor of aid.

There is no need to develop this view more broadly as it is commonly known. It is possible however, to raise some counter-arguments against it because it gives ground to some justified doubts. In this paper I am trying to demonstrate that in non-capitalist development of LDC the role of agriculture may and should be much greater than it has been so far commonly accepted. Agriculture as a factor initiating and/or accelerating development may have much more to say than it was observed up to now in the majority of LDC which were trying to enter or have actually entered upon the road of accelerated development. This refers to a better use of resources (capital and the human factor) as well as to the growth of both productivity (per head of an employee as well as per unit of input) and income per capita (i.e. higher consumption and accumulation).

It does not follow from the foregoing remarks that I understand this problem alternatively i.e. that agriculture should have priority in relation to industry. It would also mean posing the problem in a biased way - only with an opposite sign. In the following consideration I quote a number of arguments pointing to the necessity of basing the development of LDC upon two pillars; one of them (agriculture) exists in all the countries in question, the other one (industry) must be constructed from the scrap in many of them. It is true to say, that the agricultural sector in the majority of LDC lags far behind the agriculture of developed countries, but still it does exist, so that economists and policy makers are faced with the problem of its modernization. The effects of the modernization may also strongly influence the development of industry as well. That is the point which is advanced here. 
It is rather obvious, that from the point of view of the stage of development of agriculture itself, LDC are by no means a homogenous group; on the contrary they may be divided into a number of subgroups, which differ among themselves in many respects. ${ }^{13}$

All the same, the role of agriculture in the process of development is usually underestimated in all those countries. In each case this problem is closely connected with the other ones which have important significance to development and are more or less controversial. For example, an answer to the question whether a greater stress within a given group of countries should be placed upon development of agriculture or on that of industry is closely interlinked with the problem whether the growth of consumption or accumulation should be accelerated first of all. It should be also born in mind that in countries which find themselves at the lowest level of development the consumption of the broadest strata of population is on the verge of biological minimum. Each growth of production per unit of inputs) is followed by a rapid growth of consumption of the rural population on the one hand, and it depends on the growth of consumption itself on the other. In case of priority given to industry the chain of consequences is somewhat different.

It is often pointed out that in many countries agricultural policy is conducted by the town and serves the interests of the town. It is usually directed by the monopolies in combination with big landlords who pursue their own aims which are in full contradiction with the interests of both small peasants and land labourers who are handicapped in their attempts at self-defence by illiteracy, malnutrition and lack of leaders. ${ }^{14}$

Within this context one often discusses the necessity of providing most modern technique to the IDC by the advanced countries, of course on conditions acceptable to the receivers. However, it may reasonably be argued that the most modern technique can not be introduced even in industry of the majority of LDC at the early stage of their development; and in agriculture this idea is even more doubtful. It seems reasonable to assume that for each country - both for agriculture and industry there is a certain technical level which should be considered optimal under the existing circumstances. As a rule it is lower than that applied at present in LDC. Attainment of this level should be regarded as a first step on the road to diminshing the gap between the two groups of countries with respect to techniques of production. 
The difficulty in bridging the gap between most backward and most modern technique in a rapid fashion is best seen in agriculture, hence the problem of the relative place of agriculture and industry in the process of development is closely connected with the problem: optimal technique versus most up-to-date technique. (This will be discussed in more detail later in this paper.)

Acceleration of development always means a flow of labour force from agriculture to industry and from village to town. If a greater stress is placed on agriculture one may diminish this flow which is usually more intense than objectively needed, i.e. if compared with new possible jobs. It may immensely facilitate the task of urban and state authorities which are responsible for appropriate development of social infrastructure: dwellings, schools, health facilities, security etc. Government expenditures on these i.tems are usually large, especially at the initial stage of development. Under these circumstances all justified economies in public expenditure may have great importance, especially in the poorest countries. Further below I shall attempt to demonstrate that a practicable intensification of agricultural production in LDC creates conditions for economically justified growth of employment of some rural population without transferring it to the towns. It makes it possible to attain the same growth of income at lower social costs, both in financial terms (e.g. expenditure on sanitary facilities in the towns) and in terms of human welfare (homelessness, criminality etc.).

The foregoing remarks claim to justify the necessity of attaching higher importance to non-capitalist agriculture in accelerated growth of LDC. It can and it should play a more important role in obtaining rapid effects in employment and better nutrition in those countries. This thesis does not stand in any contradiction to the other one that industrialization is necessary. In a long run industrialization does not compete with development of agriculture. Quite the contrary, their development is mutually complementary and helps in reducing the danger of inflation, which is very often a barrier to development in LDC. ${ }^{15}$

\section{Employment policy in agriculture}

As it is well known, the share of employees in agriculture in the LDC is approximately $3 / 4$ of the overall labour force, and their share in GNP is below $50 \%$. It means that human and physical resources of LDC are employed here less efficiently than the average; the comparison with the efficiency concerned in the highly industrialized countries is even less favourable to LDC. 
Physical resources of agriculture mean, first of all, land which is now only partially cultivable under the technique already applied. ${ }^{16}$ Unequal distribution of land means that only a small proportion of it is cultivated by small peasants. It follows that bringing into use of at least a part of land which is not cultivated today in order to raise cash crops or food crops, or for purpose of more intense and more rational cattle raising, would ensure employment and income to a large number of families which are in "surplus" nowadays in agriculture. However, all changes for the better depend on implementation of a radical land reform, as mentioned earlier.

As is proved by the experience of both centrally planned and some market economies, the agricultural reform has become a vital breakthrough not only in agriculture itself, but also in the other branches of the national economy. There are no reasons, why its significance to accelerating development of non-capitalist agriculture in LDC would be smaller, provided, it is so organised and implemented as was described above.

It cannot be denied that a thorough-going agricultural reform is not an easy task. This can be accomplished exclusively by a strong and progressive government which wants and is able to mobilize appropriate financial, human and physical resources for that purpose. But the benefits which follow there from are immense and long-lasting:

i) political ones: removal from power (direct and indirect power) the most backward social groups, i.e. quasi-feudal landlords;

ii) economic ones: redistribution of national wealth and income in favour of the most numerous social strata which is vitally interested in development;

iii) socio-cultural ones: it is an expression of social justice and a basis for abolishing malnutrition, unemployment, illiteracy and thus to increase the propensity to work and to raise its marginal productivity.

In other words every successful landreform is followed by serious strengthening of anti-capitalist feelings and socjalist-oriented mode of production in agriculture. It is then a great support for government in its further effort aiming at the reconstruction and modernization of the whole economy.

These are the reasons why agricultural reform is a key to accelerating development of agriculture in LDC, especially of non-capitalist type of development. The same however, explains why it is so difficult 
to be implemented. Besides strong counteraction of the quasi-feudal landlords (e.g. in India and Ethiopia), the other major handicap is a lack of financial and organisational means. It seems, however, that these difficulties do not present an unsurmountable barrier to a government which sincerely wishes to serve the interest of its nation. Mobilization of appropriate domestic inputs and possible foreign assistance may be - without great difficulty - an instrument in solving the problem, especially as what is needed here is not once-for-all big expenditure but expenditures spread over a certain period of time. As their effects are almost immediate, the government concerned has an ever broader scope of manoeuvre. This means gradual intensification and broadening of agricultural production and cattle-raising, which entails a growth of employment and income of the rural population.

Productivity of labour force in agriculture of LDC is far away from being optimal both in those countries and regions where there is a relative surplus of cultivable land in relation to the supply of labour (e.g. some countries of Africa and Latin America) as well as in the other ones where there is a relative excess of labour in relation to the supply of land (e.g. in South-East Asia). Thus, all symptoms of wasting the labour force may be observed here: voluntary unemployment (e.g. village feasts) non-voluntary one (e.g. belonging to some castes), structural and seasonal unemployment and/or underemployment. As it has been estimated, employment of an adult man in agriculture is only about 1000 hours per annum. About half of this time is used for executing non-agricultural work of an artisan or commercial type and about $1 / 3$ for paid work on bigger farms in particularly intense field work. ${ }^{17}$

Without any risk of serious inaccuracy one may say that underutilization of labour force and all its consequences appear as characteristic features of all LDC. This disguised unemployment or partial employment is practically impossible to assess in terms of figures despite some attempts which have been undertaken up to now. ${ }^{18}$ Finally, the so-called "baby boom" now taking place in LDC explains why the population and the demand for consumption goods is growing faster than the supply of labour/and supply of goods. 19

This brings about a growing discrepancy between production and consumption of consumer goods; under the conditions of under-utilization of existing labour force this leads inevitably to the growth of the number of people suffering from hunger. 
Under these circumstances, there is a tendency to look for employment for "surplus" labour force in urban occupations, especially in industry. This is certainly a correct solution in a long run, when developing industry, artisanship, construction etc. are an attracting force for a village population, where from it is being pushed out by additional. capital equipment efficiently applied in agriculture. There is no reason why this solution known from the historical experience of the highly advanced countries cannot be repreated in IDC, perhaps in a somewhat modified form. In a short run, however, the migration to towns is usually much greater than new job opportunities there, because labour force is pushed out from villages by hunger. It means that the only thing which changes is the place, where people are suffering from hunger. The situation observed in such towns like e.g. Cairo, Calcutta or Dacca are good cases in point.

Furthermore, young people migrate more frequently than the family people, and ceteris paribus more often find jobs. But the point is, how to support first of all the fathers of big families. Such a "surplus" labour cannot be absorbed even by the most optimistically planned development of industry in LDC over the coming 10 years. The alternative consists then in trying to find out additional job opportunities of justified employment and growth of income in agriculture itself, or better to say in villages.

It seems to me, that additional working places for rural population can be found both in agriculture itself and in non-agricultural occupations, but without migrating to the towns. The range and kind of occupations depends upon capital inputs which the government may finance, because only the government is able to do it at an initial stage of development. Many arguments may be delivered, that at this development stage the inputs in agriculture seem to be more effective than those in development of many branches of industry. If they are invested in an appriopriate way, they may give multiplier effects; I will try to explain this point below.

Vast possibilities of raising employment and agricultural production exist in increasing the productivity of soil, which usually requires better irrigation. This kind of work, however, may be spread over a certain time period and - at least partially - may be done by peasants concerned. It means that this kind of intensification of land utilization may bring very positive results. It should also be borne in mind that it might be easier getting financial, technical and scientific assistance for that purpose than for any other, at least in some LDC. 
Another potential way of fuller utilization of existing "surplus" labour force leads to better exploitation of plots already under cultivation through more appropriate choice of plants to the quality of soil, better selection of seeds, greater use of fertilizers and pesticides and so on. The results of the so-called green revolution of the 1960 's clearly demonstrate what advantages could follow at least some of those innovations. "Green revolution" also indicates that the need for assistance for that purpose to peasants does not exceed the possibility of the majority of IDC, but requires a highly efficient organisation in its distribution and application. The important thing to remember is that these innovations should not become - as in the case of green revolution - available only to rich peasants who have an easier access to credit, markets and additional labour force; they also assume risk more willingly, and the risk is always present in such cases. Thus, innovations under consideration require good organisation of the distribution of credits, fertilizers, seeds etc. which are made available to peasants as well as effective control over their application and preventing possible frauds.

"Green revolution" up to now referred only to the basic food article of the population of South-East Asia (rice). The innovation under discussion should, however, be extended also to plants destined exclusively or mainly to the market. Combining the production of cash crops with foods crops in the same farm may even be possible without increasing the acreage of land. The principle of multi-crops seems particularly adequate here because it makes possible to exploit the time period between seasons, i.e. between sowing time and the harvest time of the main crop.

Another field of utilising the existing "surplus" labour may be found in an extension of non-agricultural activities without changing the place of living. They nay be of course either paid for, or performed within the peasant's own household for its own needs. The first of them include e.g. construction of infrastructures - like roads, irrigation, energy network, housing, schools etc. The financial and organisation effort of such programmes has to be undertaken by the governments concerned, the economic effects of them, however, are extremely far reaching, expressed both in economic and in ideological terms. Additional wages paid to extra employees create effective demand for goods of agricultural and industrial oxigin, followed by a secondary growth of employment and demand. Furthermore, new elements of 
infrastructure either increase the production (e.g. irrigation) or intensify its market-orientation (e.g. building warehouses, roads, railways) or make life in the villages happier (e.g. electric energy).

The other kind of activity for rural markets are all types of artisanship. Their range increases along with the development of agriculture, creating new job opportunities for "surplus" labour in agriculture. These are e.g. employment in making clothes, repairs of bicycles, repair and construction of houses, repairing tools, hair-dressing etc. Such work is usually, at least partially, paid for in money, sometimes partially in natural form (food products), but the importance of the latter form of payment decreases along with development of agriculture.

Work performed to meet the needs of one's own household (repairing houses or preparing food and heating) usually does not involve any capital inputs. It makes however, the village life more pleasant, having also the productive effects, (i.e. fuller and better reproduction of villagers' labour force). Here also some sort of instruction by specialized governmental agencies is needed for improving employees' qualifications in an informal way while performing this kind of work.

It is estimated that today approximately $20 \%$ of the labour force of an African village depends upon non-agricultural activity for subsistance. This percentage may easily be increased, although today's $20 \%$ can hardly be regarded as fully employed.

It has also to be borne in mind that the supply of labour grows and will continue to grow over the coming years faster than the supply of cultivable land, even if one takes into account the above mentioned potential increase of the acreage. This needs an increase of productivity both per 1 ha and per head of employee preceded by the necessity to introduce technical improvements. Such improvements require additional capital inputs and an access to appropriate technology. Thus, the capital factor and quality of obtainable techniques are the central points in development of agriculture.

The above mentioned fields of creating new job opportunities at the village level are followed also by some socio-political consequences, especially important for further development of the economy along non-capitalist path. It increases socio-political consciousness of peasants and landless villagers, and strengthens their solidarity and support for government, which has taken care of them. This makes easier their transformation process into modern social class, which can carry on the struggle for social justice and economic improvement of all the society of LDC. 


\section{Choice of technology}

Without any doubt, no development of agriculture can be expected in LDC without technical progress. ${ }^{20}$ But there are also strong reasons to believe that an excessively big jump in agricultural technique, e.g. directly from primitive plough to a tractor, need not increase the agricultural production at all but may lead to a rise in number of rural unemployment and underemployment and thus contribute to greater malnutrition. Such a technique is suitable for developed countries, of course, because it limits the growth of employment and increases the production of market crops. The technique needed for LDC must serve first of all those who are below the poverty line. That is, technique under which smaller capital inputs for improved tools available tosmall peasants are used by them more efficiently. It gives employment to small enterprises which are producing those tools while using local raw-materials. On the other hand, such a technique is more suitable to expand the scale of production of the goods of mass consumption, that is to say, to conduct a direct fight against hunger. At the same time it increases direct involvement of broader strata of the population of LDC. ${ }^{21}$ In the light of the well-known growing shortage of food in LDC this is an argument of paramount importance particularly with reference to accelerating the development of non-capitalist agriculture in LDC, especially in initial period of it. In the course of further development and rise of co-operative units of production in the agriculture of LDC the need for cash crops - besides food crops - is felt ever more strongly; an economically justified need for tractors axises only as a result of that. Thus, the technique which is needed in IDC at the early stage of development should be suitable for small farms; only in this way it can contribute to a relative increase in their productivity and improvement of the food situation of the poorest strata of population in LDC.

A certain role in accelerating the development of agriculture in some IDC may also be played by second-hand technique, which is especially suitable in production for local market (e.g. in Brazil) while displaying a high degree of competitiveness in relation to the most modern technique (e.g. in Japan). The general rule is, however, that the technique adequate to agriculture in LDC must be relatively modern and efficient, but different to that applied in DC. This should be so because it is destined for production of different goods, by using factors of production in different proportions under different climatic and socio-political conditions. 22 
The answer to the question what kind of technique is most suitable in a given country at a given level of development may be provided by special research undertaken by LDC themselves although with the help of foreign specialists. The object of this kind of research must be also the capacity of the importer's economy to adapt imported technique and to create its own optimal type of it on the basis of imported one.

Clearly, import of technique depends upon its price and upon other factors (e.g. credit conditions, date of delivery, aid of specialists in adapting it to local conditions etc.). Thus, its influence upon the distribution of income may be very different. It is up to the policy makers to chose such a technique which is helpful in attaining envisaged targets (e.g. redistribution of income in favour of the poorest rural population). It is a further problem, which should be subject to above mentioned scientific investigations; they are of superior importance to development of LDC. 23

The choice of technique which is adquate to the given level of development of agricultural production cannot leave out of account the level of skills and the rate of acquiring them by persons who are to apply it. This refers in particular to young people, who are more energetic and somewhat better trained and who have a particular inclination to flee from the village. Inflow of a more modern technique which could be used to improve the situation of their families as well as that of the remaining part of the population will create new work opportunities for them in the countryside without looking for them in the town, where such opportunities are extremely limited.

Policy makers who adopt decisions concerning the quality of imported technique for the needs of agriculture face numerous contradictions which they are trying to solve in an optimal fashion. The first of them arises from the fact that they are expecting financial and technical assistance from DC, which are also exporters of food. They prefer to grant assistance in form of grain rather than in form of technical equipment to expand the production of LDC. On the other hand, assistance of the socialist countries is far from being sufficient. This constitutes an additional argument for continued application of labour -intensive techniques, for increasing agricultural production rather than the most modern techniques, at least for a certain period of time.

Another dilemma facing the policy makers in LDC is to what extent imported technique should serve increasing agricultural production for internal consumption and to what extent this production should be export-oriented. The first one is necessary to diminish, and eventually 
abolish, malnutrition of the broad sections of the population and the second one is required to pay among others for the imported technical equipment. Export needs are the greater the smaller are the possibilities of increasing internal accumulation in a given LDC and/or the shorter are repayment periods of the credits obtained.

Next significant difficulty connected with imported technique is its destination. It has already been argued earliex that both economic and social considerations justify directing it primarily to peasant farms. Periodic intensification of work in agriculture implies that at the initial stage primary importance should be attached applying machines not to the fields work but to the work which is performed after the harvest (threshing machines, mills etc.). They make it possible to release a relatively large number of hands to work in the field on the second crops which can and should be introduced more widely.

Introducing machines to mechanize the work in the fields is a task for later periods. Japanese experience which is already 50 years old and contemporary research in India confirm that thesis. ${ }^{24}$ on the other hand, however, medium-sized and big farms - if they are not abolished by land reform - have a great possibility of buying machines and tools precisely for field-work purposes. It is the task of the government also to solve that dilemma.

\section{Food production}

Whether agriculture is being developed along capitalist or non-capitalist lines depends among other things upon the ultimate aim to which the process of development is subordinated. The paramount aim of the first stage of LDC's development is abolishment of all forms of unemployment and through redistribution of national income in favour of the poorest and broadest strata of population. It requires increasing food crops production, to which employment policy and choice of technology must be subordinated. This is also taken into account in grant policy of DC, without which that aim could not be attained at least in the poorest countries. ${ }^{25}$ It should not be also forgotten that in many IDC average income per head has risen by $40-80 \%$ over the past 40 years, but the poorest part of the population suffers from malnutrition as it did before. ${ }^{26}$ One of the reasons why it is like that is that the role of agriculture as a separate branch of national economy is underestimated and the capitalist way of development of both industry and agriculture in LDC is overestimated by their policy makers. As a result about $4 / 5$ of resources are concentrated in industrial investments, being as a 
rule capital -intensive ones; they serve to produce goods of secondary priority, i.e. not food for the poorest strata of the population, who are unable to change this state of affairs. This situation could be altered exclusively by development of non-capitalist agriculture, i.e. by cooperative farms and state farms, which are able to achieve - as the primary aim - self-sufficiency in supplying food to the whole population, raising significantly its comsumption per head.

Improvement of the nutrition of the rural population does not mean only a quantitative growth of production of food crops but also increasing their variety and quality. Improvement in the latter respects is at least equally important as the growth in quantity, especially so that it is not so clearly perceived by interested persons themselves. Thus, policy makers are faced with the task of, first, "creating" such a need and, second, meeting this need. This is indispensible in view of the fact that abolishing malnutrition means abolishing depreciation of human capital; improvement in the quality of foods implies reproduction of that capital. This problem acquires particular importance in non-capitalist form of developing agriculture in LDC when it is viewed also at this angle.

As I have mentioned above, the LDC may successfully reach that aim after completing all the preconditions mentioned earlier in this paper. No need saying that it is very difficult and complicated task even for the progressive policy makers. But it is not impossible, as it can be noticed e.g. from the Nigerian case study, called "Operation Feed the Nation". 27 Trying to reach self-sufficiency in food production, Nigerian government has allocated nearly $\mathrm{E} 480 \mathrm{mill}$. for development of its agriculture. The project has been prepared very carefully with a special emphasis put on the infrastructure concerned: modernisation of transport and distribution, irrigation and storage facilities. The university students have been mobilised for teaching new farming techniques and handling better equipment, emphasizing the dignity of labour and inclining to higher propensity to work.

It has to be mentioned finally, that immediate necessity of increasing food production in majority of LDC is ordered not only by undernourishment of hundreds of millions of human beings. It is also badly needed for struggle against neo-colonialism. As the USA are the biggest world producer of surplus crops, they can easily use it as a tool of neo-colonial policy. Even a potential danger of that kind has to be an effective warning for LDC concerned. And one can prove that in some cases it is a real state of emergency. And that is why it cannot be disregarded. 28 


\section{Conclusions}

1. Non-capitalist development of the whole economy of LDC especially their agriculture depends on appropiate institutional framework. Such a framework can be created in result of social revolution which has to precede an economic development.

2. The take-over of political power by the progressive group of people interested in socio-economic development of the economy should be accepted as the starting point of the above mentioned revolution.

3. The precondition of development's acceleration of agriculture in LDC is a broadly conceived land reform, which includes at least redistribution of land, abolishment of land renting, extinction of usury capital and introduction of professional training.

4. The role of agriculture in the process of non-capitalist development of LDC should be much greater than already played in the majority of countries. In this way there might be reached much greater and relatively quick results in defeating the so called unholy trinity (i.e. hunger, unemployment and illiteracy), assuming the proper agricultural policy, of course.

5. The land reform is a key to accelerating non-capitalist development of agriculture in LDC; it has far reaching political, economic and socio-cultural consequences to their whole economies.

6. Fuller utilisation of agricultural labour force in LDC may be achieved in a short run through creating additional working places both in agriculture itself and in non-agricultural occupations without migrating to the towns. In a long run, however, such a migration is unavoidable.

7. The most modern technique cannot be a proper (optimal) one for agriculture of LDC at its present stage of development. It should be relatively modern and efficient, but different to that applied in DC. If imported from DC it should be properly adapted to production (or the same ones but in different proportions) and in different conditions.

8. The non-capitalist agriculture should be subordinated to abolishment of malnutrition of the rural population through doing away with all forms of unemployment and through redistribution of national income in favour of poorest strata of population. 


\section{NOTES}

1. Even in those LDC where the main part of GNP is produced in agriculture less than $10 \%$ of institutional credit is given to agriculture, and small peasants get only an insignificant fraction of it. Agricultural credit is often entirely omitted in the development plans. Agriculture Credit for Development, Milan 1975, p. 2-5.

2. Employment, Incomes and Equality, Geneva, ILD 1972, p..112.

3. As I shall try to argue, the non-capitalist development is a way of creating the material prerequisites for building the socialist society, of course, after some transitional period. See also: $V$. Solodovnikov, V. Boguslavsky, Non-capitalist Development. An Historical Outline, Moscow, Progressive Publ. House 1975

4. See, G. Starushenko, Africa Makes A Choice, Moscow, Novosti Press Agency, Publ. House, 1975, p. 52 .

5. This subject is treated in a more extensive way in a subsequent part of the paper (see $\S 3$ ).

6. See e.g. Agrarian Change and Economic Development, London, Methuen 1969 , p. 150 and the following as well as: T.H. Lee, Food supply and Population Growth in Developing Countries: A Case Study of Taiwan in Agricultural Policy in Developing Countries, London, Macmillan $1974, \mathrm{p} .180$ and the following.

7. See also U.J. Lele, The Role of Credit and Marketing in Agricultural Development in Agricultural Policy ... p. 42.

8. See $w$. Lenin, "Two Tactics of Social Democracy in the Democratic Revolution" in Collected Works, vol. 9, Moscow, p. 48.

9. See Employment, Growth and Basic Needs, Geneva, ILo, 1976, p. 3-4.

10. See e.g. Kadt de E., Education and Employment in Mexico: Some Thoughts on Specific and Feasible Policies, IDS, Discussion Papers Nr 55, 1974, p. 8.

11. This point is more extensively developed in part 2 of this paper, where industrial and agricultural market production in relation to each other is being discussed.

12. Indirect planning - as opposed to direct one - means by and large that only some of inputs and outputs of the national economy are being fixed at the central level. As a rule, however, they are the most important ones to the economy as a whole, e.g. for infrastructure, for land reform, for state farms and so on.

13. E.g. the Northern Africa countries as opposed to the Tropical Africa countries.

14. E.g. M. Lipton, Urban Bias and Agricultural Planning, Brighton, IDS, 1968, p. 61.

15. This point is emphasized by numerous authors of recently published books; e.g. A.P. Thirwall in Inflation, Saving and Growth in Developing Economies, London, Macmillan 1974, says: "The Latin American countries provide case studies of the dangers of inflation and point to the vital necessity of a sound agricultural base before launching an expansionary programme of industrialization and employment creation by inflationary means". p. 231.

16. The part of land cultivable in Latin America, Africa and in the Middle East is only 6-7\% of the whole area of those territories, and pastures are respectively 24 음, 32음 and 17응. See E. Boserup, "Food Supply and Population in Developing Countries" in Agricultural Policy ... p. 168-9. 
17. See Agricultural Policy ... pages 279-281.

18. E.g. according to one such estimate, the sorcalled absolute poverty in the $1970^{\prime} \mathrm{s}$ in LDC referred to over $100 \mathrm{mill}$. peasant families and land labourers, or more than $600 \mathrm{mill}$. persons. Agricultural Credit ... p. 2 .

19. Respective data for the Indian subcontinent are as follow: (the $70^{\prime}$ $70^{\prime} \mathrm{s}$ ) 2,5\% per annum and 1,8-2\% per annum (In Search of population Folicy, Washington, National Academy of Science 1974, p. 16).

20. See, W. Lenin, Collected Works, vol. 29, p. 421.

21. See e.g., M. Lipton, Urban Bias and Food Policy in Poor Countries in Food Policy, 1975, p. 49 and A.K.N. Reddy, "The Trojan House" in Ceres, FAO Review, 1976, p. 41.

22. See e.g. H.W. Singer, Policy Document on Technology, Brighton IDS, 1976 and "Five Wasted Years" in Focus on Technical Cooperation $\mathrm{Nr}$ 1/1976. This refers in particular to non-capitalist development of agriculture.

23. See e.g. Tretij mir i nautchno-technicheskij progress, Moscow, "Nauka", 1974 ("Third World and Technical Progress"), Chapt. 1.

24. See e.g. C.H.H. Rao, "Employment Implications of the Green Revolution and Mechanisation. A Case Study of Punjub" in Agricultural Policy .... p. 350 .

25. An expression of this awareness is reflected i.a. in establishing International Fund for Agricultural Development with a capital of $\$ 1$ bill.

26. See e.g. M. Lipton, Urban Bias and Food Policy ..., p. 42.

27. See e.g. "Nigeria: Operation Feed the Nation" in Africa, No. 60/ 1976.

28. See e.g. H. Tuomi, The Food Power: The Position of Main Exporting Countries in World Food Economy, Univ. of Tampere, Institute of political Science, Offprint Series 1/1976, pp. 126 and 132. 
Parviz Khalatbari

APPLICATION OF THE MARXIST REPRODUCTION MODEL TO

THE DEVELOPING COUNTRIES

Considering that models are only an auxiliary construction for the logical treatment and explanation of the processes of economic reality and its law-governed processes, it goes without saying that these models are abstract pictures of reality which do not show all aspects. They present reality as seen from quite a definite and essential perspective.

The presentation of the economic processes and their law-governed processes in the developing countries cannot be effected without the model as an auxiliary instrument. The elaboration of such a model is connected with certain difficulties which must be sought, above all, in the non-uniform reproduction system of the developing countries, because the reproduction process varies from country to country. What matters here is to find a model outlining at least the essential processes in the developing countries. But even from that angle, a certain differentiation or grouping of the developing countries is inevitable. Here the attempt has been made at elaborating a simple model representing the main features of the basic type of developing countries. It relates mainly to that type of developing countries in which the bulk of the national income comes from agriculture, and where the agricultural products account for a large share among export goods. With a slight modification, this model can also be applied to other types of developing countries. In this paper attention is drawn to the various places and to the differences, and it is sought to modify the model with a view to intensifying its power of statement. Further on it can be complemented and rendered more precise by other models or partial models. In this paper we proceed from a simple model in which population growth is not taken into account. This does not mean that population growth is of no importance, but that population growth will aggravate the difficulties of the reproduction process. Defects of the reproduction process are not the result of population growth but are inherent in the present-day mode of production. Population growth is simply in a position to accelerate or sharpen the phenomena of defect. At any rate, principal changes cannot be recorded in the models. In this model, for reasons of simplicity, values have often been equalized with prices. In the models, 
the developing countries have been regarded as component parts of the capitalist world economic system, and the reproduction process has been examined within and without this framework in connection with that system.

The starting point of this treatise is a model of dual economy, i.e., co-existing capitalist and pre-capitalist relations in the developing countries. In other words, a situation is involved in which a stagnating and a dynamic system exist next to each other. To begin with, agriculture being the main national economic branch represents the stagnating sector. Agriculture as a stagnant sector embodies a simple reproduction process which can be characterized as follows:
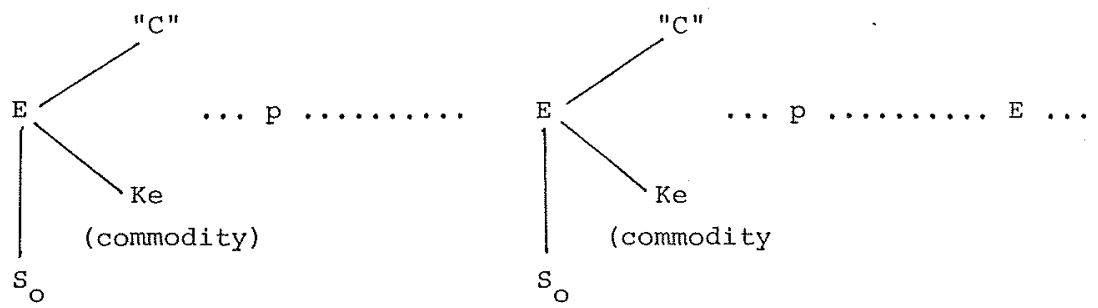

$$
E=" C "+\mathrm{Ke}+\mathrm{S}_{\mathrm{O}}
$$

$\mathrm{E} \quad=$ harvest

"C" = advance capital

Ke $=$ effective comsumption of producers

$s_{0}=$ economic surplus (as a rule rent of products).

As can be seen from this pattern, what is involved here is the simple reproduction process.

In the pattern it is taken for granted that ke corresponds to the subsistence minimum of the producers and is completely consumed by them. In a similar manner, " $C$ " in the form of seeds, fodder etc. has been subtracted from the harvest and remains constant in the production cycle. In the pattern $S_{0}$ means the agrarian surplus, the surplus products which the peasants, as a rule, hand over to the big landowners in the form of ground-rent and which indeed consists of the largest portion of the harvest. The agrarian surplus is not invested in agriculture, it is sent to the towns and cities in the shape of commodity or is exported.

Agricultural production, practically always remains constant apart from climatic instabilities, and thus the same is true of its component parts. In this sector there exists a comparative stagnation. The developing countries differ in relation to agrarian surplus production and stagnation in agriculture. 
The dynamic sector in the developing countries consists of two sectors isolated from one another. On the one hand, they are composed of local industrial branches. which, as a rule, produce consumer goods and can be regarded as department II. On the other hand, this sector comprises the foreign capitalist entrepreneurs, be that in mining or in the plantations, which as a rule produce the raw materials and can be considered as department $I$.

In contrast to the agricultural sector, the reproduction process is extended. That means that surplus value is always transformed into additional capital (i.e. constant and variable capital). The reproduction process continually repeats itself, but on a basis broader than the preceding.

The Marxist simple reproduction model is the starting-point for the elaboration of the basic ideas on the reproduction process in the developing countries which can be expressed in a simple model.

Marx examined the correlation of the two departments and arrived at the following equation:

$$
I(v+m)=I I C
$$

$\mathrm{v}=$ variable capital
$\mathrm{c}=$ constant capital
$\mathrm{m}=$ surplus value

The pattern made out by Marx refers to a mature capitalist society which exclusively consists of two classes. That means, where capitalism has taken hold of both agriculture and industry. Thus a bi-sectoral model like Marx's comprises both agricultural and industrial production. I

This model can be applied to other than mature capitalist countries, in our case to the developing countries, only on condition of some modification. This modification is based on processes taking place in the developing countries. Here the national economic processes are not purely capitalist and dynamic but dualistic. While the Marxist bi-sectoral reproduction pattern is applicable to the capitalist dynamic sector, the stagnating non-capitalist sector viz. agriculture stays outside the pattern. The issue here is two sectors with different reproduction processes. On the one hand it is the dynamic sector with department $I$ and II which is subject to the capitalist laws of the reproduction process, on the other, it is agriculture, the stagnating sector of national economy in which capitalist mode of production has not yet prevailed, and production of means of production and means of consumption have not yet been elaborated as two distinct features as they exist in capitalism.

Both sectors, the dynamic and the stagnating one, being component parts of the national economic reproduction process have a certain re- 
lation to each other. This relation is not based on the merger of agriculture and industry to form a unit existent in mature capitalism and in the Marxist model. What matters here is the relation between the sectors involved in capital circulation, and those not involved in circulation of capital.

Apart from this essential difference existing between the Marxist model of the reproduction process of mature capitalism and the Marxist reproduction model for the developing countries, there still exists another difference between the two models. The Marxist model of the reproduction process of mature capitalism relates to a society the production of which is subdivided into two large departments. The location of both departments is in one and the same society. In the developing countries, it is somewhat different. The existing department I predominantly consists of foreign enterprises in mining and plantation. They are produced in accordance with the requirements of the metropolis and are being developed hypertrophically. They have almost no relation to department II of the respective developing countries, and there is no organic relation between them. Strictly speaking, they are a component part of the reproduction process in the metropolis. The remaining branches of department $I$ in the developing countries are insignificant. Thus we have left aside, for the time being, department I in this model. This means that unlike the original pattern, the dynamic sector in the developing countries consists only of department II. In other words, the location of departments I and II is not in one and the same society, in the developing countries. While the location of department I is situated in the highly developed capitalist countries, the location of department II is in the developing countries. The different location of departments I and II results in the fact that the turnover between both departments can be effected only through the importation of $\mathrm{I}(\mathrm{v}+\mathrm{m})$ and the exportation of II $c$.

This means that in this process foreign trade plays a decisive role. In this connection it has to be taken into account that it is hard to market the products of department II of the developing countries in the metropolitan countries. The main export goods of the developing countries do not come from the production of department II. The products of department II are above all sold in the home narket. Hence, the developing countries have only one possibility of exchanging the products of department II with another sector viz. agriculture. At best it is an agrarian surplus $\left(S_{O}\right)$ that can be exchanged for II $c$. But it is preciseIy the agrarian surplus that represents the main export goods of the developing countries; these goods can be exchanged for products of department $I$. Thus the equation reads as follows:

$$
\text { II } c=I(v+m) \text {, }
$$


which is true of the developing countries as opposed to the original pattern consisting of two different processes. On the one hand, it is a question of exchange between II $c$ and $s_{O}$, i.e.

$$
\text { II } \mathrm{C}=\mathrm{S}_{\mathrm{O}} \text {, }
$$

on the other it is a question of exportation of $S_{0}$ and its exchange for I $(v+m)$, hence,

$$
S_{0}=I(v+m) \text {. }
$$

Thus the agrarian surplus. functions as a catalyst in the process of turnover between II $c$ in the developing countries and $I(v+m)$ in the metropolis. By this the role of agriculture in the reproduction process has been decisively raised. The course of the reproduction process depends on the character of the agrarian surplus; and in this way a number of questions can be clarified.

Let us now have a closer look at this model. The agrarian surplus appears twice in the process of turnover between II $c$ and $I(v+m)$. On the one hand it is here our intention to examine the relation between the reproduction process in agriculture, i.e. the stagnating sector and department II as the dynamic sector in the developing countries. On the other, light is to be shed on the relation between agriculture of developing countries and the reproduction process in the metropolitan countries.

The agrarian surplus is subdivided into three parts if it is entireIy productively used outside agriculture:

$$
\mathrm{S}_{\mathrm{O}}=\mathrm{S}_{\mathrm{r}}+\mathrm{S}_{\mathrm{V}}+\mathrm{S} \exp \text {. }
$$

$S_{r} \quad=$ raw material for department II (part of II $\mathrm{C}$ )

$\mathrm{S}_{\mathrm{V}} \quad$ foodstuffs for the working people in department II (II $\mathrm{v}$ )

$S_{\text {exp. }}$ = surplus for export for the sake of importation of $I(v+m)$ Thus the agrarian surplus is in the first place exchanged for II $\mathrm{v}$ and II $c$ (raw materials or means of production). In the extreme this process can be presented as follows:

$$
S_{0}=I I(c+v) \text {. }
$$

The simple reproduction process becomes conceivable only if the products of department II i.e., II $(\mathrm{c}+\mathrm{v})$ are absorbed by agriculture. or to be more precise, if the owners of $S$ are in a position to absorb the products of department II.

As a matter of fact what matters in the Marxist reproduction pattern is not just the simple reproduction process but the extended reproduction process. In this case part of the surplus value ( $m$ ) is accumulated, and it is reinvested according to the organic set-up of capital. Both 
in department $I$ and II the surplus value is divided into constant and variable capital. The turn-over between the two can be characterized as follows :

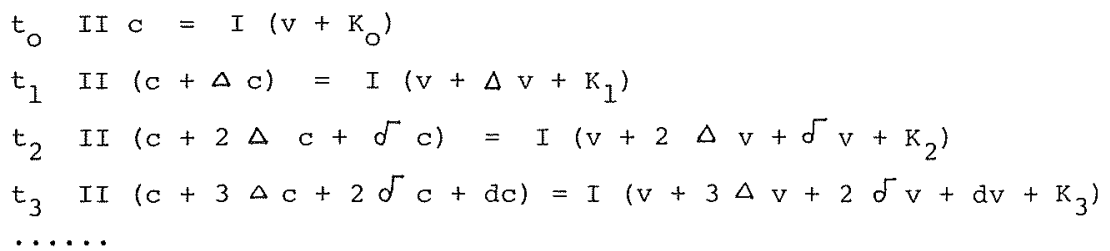

$t_{0}, t_{1}, t_{2} \ldots \ldots=$ period of reproduction

$\mathrm{K}_{\mathrm{O}}, \mathrm{K}_{1}, \mathrm{~K}_{2} \ldots \ldots=$ = revenue of entrepreneurs

It is a dynamic process, that is, both sides of the equation grow continually. The process of growth depends on the extent to which the conditions of balance between the two departments have been fulfilled, i.e. development of the departments is to be such that it promises optimum growth of both departments.

Let us now take a modified look at this pattern in the developing countries. The turn-over between both departments does not take place within the boundaries of one society but amounts, at the same time, to a process of exchange between two different countries - developing and highly developed capitalist countries. But one must not forget either that the turn-over between the two departments takes place under peculiar conditions.

II $(c+c)$ as products of department II cannot be marketed in the highly developed countries while $I(v+m)$ is extremely necessary in the reproduction process of the dynamic sector in the developing countries. This exchange can take place thanks to the employment of the agrarian surplus as a catalyst of the turnover intermediate departments. That means that the products of department II, $i . e$. II (c + c) are to be exchanged for the economic surplus of the stagnating sector $\mathrm{S}_{0}$, and $\mathrm{S}$ o is to be exchanged for $\mathrm{I}(\mathrm{V}+\mathrm{m})$.

Let us examine this process more thoroughly. To begin with, it is presupposed that the entire surplus value is again and again accumulated supposed that the entire surplus value is again and again accumulated and invested in department II. At the same time the whole agrarian surplus enters the exchange process. The latter creates both raw materials and foodstuffs and the means of production for department II through export; this runs as follows:

$$
\text { II }(\mathrm{c}+\mathrm{v})=\mathrm{S}_{\mathrm{O}}
$$

Supposing the owners of the economic surplus in agriculture have seen from a purely subjective point of view - no limited needs for the 
products of department II, then it is, however, objectively a relation between two qualitatively different categories. While $S_{0}$ under the conditions of stagnating agriculture remains constant, II $(c+v)$ continues to grow unceasingly and according to law. That means the need of the dynamic department II for raw materials and foodstuffs and for exportable agricultural products continues to grow. Indeed, department II meets the demand for raw materials and foodstuffs at the expense of the exportable part of the agrarian surplus. Thus $S_{\text {exp. Will even quantita- }}$ tively decrease under conditions of stagnating agriculture. This in turn implies that the procurement of means of production for department II is severely hampered, which engenders the danger of a slowed-down growth rate of department II or its paralyzation or even ruin.

A balanced exchange between II $(c+v)$ and $s_{O}$ is possible only through the growth of $\mathrm{s}_{\mathrm{o}}, \mathrm{i} . \mathrm{e}$. through the growth of the agrarian surplus. In a stagnating system this can take place in two ways. On the one hand $\mathrm{s}_{\mathrm{o}} \mathrm{i} . \mathrm{e}$. the rent of products can be enlarged at the expense of the peasants' effective consumption $\left(\mathrm{K}_{e}\right)$. In our model $\mathrm{K}_{e}$ is assumed as a minimum. Any further attempt, which is made with a view to limiting the minimum of the means of subsistence of the rural producers, will jeopardize the agricultural reproduction process.

Enlargement of $\mathrm{S}_{\mathrm{O}}$ can also take place at the expense of shortening the time of fallowness of the land. Permitting fallow of the land for a certain time, under the presentday backward production conditions in the agriculture of the developing countries is the main pre-requisite of the reproduction process. Violation of the conditions would reduce the yield per hectare, which ultimately would result in an agricultural catastrophy.

But these two measures - inasmuch as they can be considered èfective and harmless - have their natural bounds. At best they are in a position to maintain the balance between II $(c+v)$ and $S_{0}$ for a certain time only.

This statement is not only true of the type of developing countries whose department I of their reproduction process is entirely situated abroad but is also true of those countries whose department $I$, at least a certain share, is at home inside the given country itself. ${ }^{2}$ It can be claimed that the additional needs of department II for means of production, raw materials and foodstuffs can be covered in the third and successive period, in a number of favourably situated developing countries, through royalties of mining industry and plantations. In this case we will be confronted with an over-production crisis brought about by stagnating agriculture. It will prevent the further deployment of royalties in this respect. ${ }^{3}$ 
In one way or another, to create a situation promising a continuous growth of the agrarian surplus will be the basic prerequisite for the reproduction process of the developing countries. The pexpetual growth of the agrarian surplus goes beyond the scope of a stagnant system.

It presupposes a radical transformation of agriculture. Here obviously a radical land reform represents the main precondition of the dynamic, i.e. normal course of industrial production. The continuous growth of the agrarian surplus is a necessary precondition of the balanced reproduction process. But this growth alone is insufficient.

Social structure in agriculture indeed concentrates all the economic surplus in the hands of a few. The masses of peasants are deprived of any surplus beyond their subsistence minimum.

The requirements of the big landowners for industrial products manufactured in their own country are low; they receive the agrarian surplus. This means that under the present-day distribution system only part of the agrarian surplus is exchanged for products of department II. The remainder is exported for the sake of importing luxury goods or is simply deposited abroad. The instability of the industrial reproduction and in the sphere of distribution. The latter factor, the sphere of distribution, which restricts the demand for products of department II and which is conditioned by the structure, at present represents an acute danger to the reproduction process in the sense of a discrepancy between the growing essence of the industrial reproduction process and the stagnating character of agricultural production.

A radical redistribution of the agrarian surplus would, for the time being, enhance the purchasing power of the masses of the population. It would offer better possibilities for the realization of the industrial products of department II, and it would strongly enlarge the margin for the dynamic sector.

Simultaneously, redistribution of the agrarian surplus in the interest of the mass of peasants is one of the major prerequisities for the continuous growth of the agrarian surplus. From here the conclusion can be drawn that in our reproduction model the agrarian surplus is the key issue. Its stagnant character contradicts its significance within the reproduction process. Its position and function in the mechanism of the reproduction process absolutely accelerates the process of pauperization of the masses of peasantry and contains a cumulative process in the direction of stagnation in industrial production.

Coordination of the character of $s_{0}$ with the character of department II as a condition of the balanced reproduction process, is based on a series of political, social, economic and technical measures which can be sumed up as a non-capitalist restructuring of agriculture and which begins with a radical agrarian reform. 
In the preceding section, only one part of our model was discussed viz. II $o=S_{0}$. The question was the turn-over between department II and the agricultural products within the developing countries. With this turn-over capitalist II would get rid of his non-exportable commodity viz, the agricultural products.

The issue in the process is the exchange of agricultural products for $I(v+m), i . e$. The procurement and replacement of IIc. In examining this aspect of the formulas, all shortcomings and difficulties in the first round (IIC $=S_{0}$ ) will be left aside, and it will be assumed that the conditions for a balanced reproduction process are available. This means, firstly, that the owners of the agrarian surplus are in a position to absorb the products of department II and, secondly, that the value of the agrarian surplus equals the products of department II.

Granted this precondition, the exchange of IIc for $I(v+m)$ through the agrarian surplus $\left(S_{0}\right)$ is conceivable. The turn-over between $S_{O}$ and I $(v+m)$ i.e. between the agricultural products of the developing countries and the industrial products of the highly developed countries is also based on some facts of basically different character:

(1) The main difference is that owing to the high ground-rent, the low standards of the transport system, the high interest rate in the sphere of agriculture and the differential rent of $I$ and II the cost of production of agricultural products, and hence the market price are very high. What is more, the cost price of the agricultural products in the developing countries remains comparatively constant which is due to backward technology and its stagnation, while the cost of production of agricultural products in highly developed countries is on a comparative decline. The agricultural export products of the developing countries are not sold at their cost of production in the world market but at world market price. This means that their constant costs of production will fall to their own detriment. Thus the agrarian products, being the main export goods of the developing countries, will supply a fund for import whose value will grow less and less. This decreasing fund for the importation of industrial goods or machines cannot meet the mounting requirements of the industrial reproduction process.

Here, a "smooth" reproduction process can be safeguarded only if the cost of production of the agrarian products sinks, i.e. If the factors contributing towards the extent of the cost of production such as ground rent, the huge differential rent of II, the high rate of interest in the rural areas etc. - are minimized. In addition to this, backward technology in agriculture has to be modernized. Transformation of agriculture too is the main precondition for a smooth course of the reproduction process. 
(2) When examining the lowering of the cost of production, the qualitative improvement of commodities has not yet been considered. But it is a fact that this factor decisively influences the exchange of agrarian products of the developing countries for industrial products of highly developed countries, because in this respect there is a decisive difference between the two. An improvement of the quality of the agrarian products can only be accomplished through variation of agrarian products by means of industrialized agriculture. Otherwise the agrarian products will remain unchanged while industrial products are subject to other laws in this respect. The industrial products are subject to qualitative changes. The process of lowering cost of production in the industrial branches is logically connected with the development of technology and consequently with improvement of quality. The process of changing quality, in a broad sense, does not only consist in the improvement of the quality of the existing products in general, but in the introduction of new industrial products. This process is connected with a number of expenditures in the field of science, training, technology, etc. which considerably and successively increases the cost of production of industrial products. This in its turn means that price movement in industry and agriculture runs in opposite directions.

The term of exchange is apparently always determined in favour of industrial products and to the disadvantage of agrarian products.

This disadvantageous situation in agriculture is inevitable since there is little room for improvements of quality and new inventions which are characteristic of industrial production.

Agriculture can, apparently, compensate this disadvantageous situation by higher productivity - higher than in industry. This means a considerable increase of the organic set-up of capital in agriculture. A rather small number of agricultural producers will allow an orientation of the growing demands of the majority of the population towards agrarian products.

Let us return now to our pattern, or to be more exact, to the second round of the model $\mathrm{S}_{\mathrm{O}}=\mathrm{I}(\mathrm{v}+\mathrm{m})$. Quality, quantity and cost of production in the agriculture of the developing countries are considered constant. On the world market, however, the price is subject to a relative decline determined by the price of agrarian products in highly developed countries. For the developing countries this means that the agrarian surplus, as to its value, is not even constant but declining.

On the other hand, industrial products are subject to price increases due to the improvement of quality and new inventions. This means 
that the balance between the prices of agrarian products in developing countries and the prices of industrial products in highly developed countries is disturbed. It is disturbed not only by the growing discrepancy between the stagnating costs of production for agrarian products in developing countries and the lowering costs of production for the same products in highly developed countries which on the world market leads to the decline of prices for agrarian products as compared with their real cost price. The balance of prices will, furthermore, change to the disadvantage of the developing countries because their products cannot be subject to improvements of quality.

A reduction in the cost of production for agrarian products by a social transformation of agriculture, the introduction of modern technology and rationalization is necessary in order to establish the balance in the process of exchange $S_{0}=I(v+m)$. It is, however, not enough. It is not only necessary to reduce the cost of production but to bring about productivity in agriculture which will allow the compensation of the inherent disadvantage of agriculture compared with industry, its disadvantage with regard to the improvement of quality and new inventions.

This process goes far beyond the margin of a radical agrarian reform and a transformation of agriculture. It is an enormous process of shifting the mass of peasants from agriculture to non-agrarian branches. It is, indeed, a re-structuring of society to be started with a radical agrarian reform.

(3) As to $S_{0}=I(v+m)$, we want to draw attention to another aspect which makes it difficult to sell $\mathrm{s}_{0}$ in highly developed countries. In these countries there is a relative decline of the demand for importing foodstuffs and agrarian raw materials. The highly developed countries themselves produce foodstuffs and due to state subsidies for agriculture they reduce their import demands. Apart from that the development of synthetic raw materials also restricts their demand for agrarian raw materials is furthermore intensified by the fact that the development of technology reduces the amount of raw materials necessary for a certain unit of production. In other words, the raw materials used per unit will be smallex in quantity and be partly replaced by synthetic raw materials. As a result of this process there is a relatively declining demand for agrarian products of the developing countries and prices go down. This means, the balance between $S_{0}$ and $I(v+m)$ is further changed to the disadvantage of the developing countries.

Thus the agrarian surplus which serves as a catalyst in the turnover between IIC and $I(V+m)$ cannot completely fulfill its function. 
This leads to a relative import reduction of $I(v+m)$ which can be proved statistically.

(4) This unsound process of exchange or turnover between the agrarian surplus of the developing countries and industrial products is intensified by the fact that the prices of agrarian and industrial products are determined by monopolies. Thus the disparity between the two prices will grow to the disadvantage of the developing countries.

The mechanism of the reproduction process in the developing countries based on agrarian products as its catalyst, is an obstacle to the reproduction process itself in these countries. It complicates the industrial reproduction process and leads to the cumulative enlargement of the gap between highly developed and developing countries.

The mechanism of the reproduction process in the developing countries endangers not only the industrial and agrarian reproduction process in these countries but, to a certain extent, it also involves a potential danger for the reproduction process in highly developed countries. According to our pattern, the export goods of highly developed countries are exclusively products of department I. In every successive period of turnover, the extended reproduction process in this department offers more products for exchange.

While these products are growing in quantity and quality, the agrarian surplus is declining in quantity and value. This complicates the sale of products of department $I$.

Taking into account the changes in the economic structure of highly developed countries and the geographic restriction of their markets, it is understandable that these countries are interested in some extension of the markets in the developing countries and also in some promotion of industry in these countries. Seen from this angle, the stagnation of agriculture in the developing countries under the present economic conditions is not even in the interest of the highly developed capitalist countries.

As we mentioned before, a balanced development of the reproduction process in the developing countries depends on the creation of higher production and higher productivity in agriculture. This requires the shifting of a large part of the rural population to non-agrarian branches. In other words, the efforts to bring about a normal function of the reproduction process go far beyond the marginal transformation of agriculture. What matters is the industrialization of the developing countries and the employment of peasants in branches of industry. Not only the scope but also the ways and means of their employment are of paramount importance for the reproduction process. 
Industrialization can be effected within the framework of the present international division of labour. The existing labour force can be mainly used for the further construction of department II. In this case, despite an increase in agricultural production and productivity, the exchange of the growing IIC for the growing $s_{0}$ will be hampered because there is only a limited demand for the products of department II, due to the limited number of agrarian producers.

Therefore it is necessary to export IIc and to exchange it directly for I $(v+m)$. If this process runs smoothly, it involves a certain approximation to the original model within the capitalist world system. The development of capitalism in agriculture leads to a gradual dwindling of the exceptional position of agriculture. Within the capitalist world system, the division of labour on the basis of the capitalist way of production is extended. In this process, the developing countries mostly serve as location for department II.

The only possible way to overcome the veakness of the reproduction process in the developing countries is the employment of people - formerly working in agriculture - in a new department to be created: department $I$. This may be done both in the national and in the regional framework. The creation of department $I$ in the developing countries will break through the vicious circle of the present deformed reproduction process. By the creation of department $I$, the reproduction process will be freed from the negative effects of foreign trade. It will depend on the development of a home market and a balanced growth of departments I and II within the country itself.

Agriculture will lose its significance as a catalyst in the exchange between the two departments. It will become an organic part of departments I and II. Thus the present deformed patterns will approach to the original patterns which allow the abstraction of the effects of foreign trade and of the exceptional position of agriculture. This process is of paramount importance for the consolidation of political independence.

It is quite natural that the realization of this process in the developing countries will meet with a number of difficulties. Therefore it should be regarded as a long-term process. The rational employment of material and human resources and an optimum combination of factors of growth are the principal line of this process. However, it requires as a precondition the creation of a normalliy functioning national economy.

In other words, it is a consciously guided process incompatible with any spontaneous development to be found in capitalism. This means 
that the realization of this way depends on whether the progressive forces have assumed state power and are able to manage this process in a non-capitalist way.

Only thus will it be possible to create a comprehensive department I and II and to bring about an approximation to the original patterns. This requires, however, close regional cooperation among the developing countries. It requires a period when each country in accordance with the other countries of its region will develop one leading sector with its resources and markets in order to create a real basis for the development of departments I and II. Only thus can one reach a normally functioning reproduction process in one region.

This process is realistic because there is not only a capitalist world system but also another powerful world system: the socialist camp which more and more becomes a decisive factor in social life and is ready to help the developing countries.

\section{NOTES}

1. Compare my essay: Zum Wirtschaftswachstum in den Entwicklungsländern, in Wirtschaftswissenschaft, Heft 9/1966, s. 1488-1490.

2. Cf. my article on "Anwendung des Marxschen Reproduktionsmodelis in den Entwicklungsländern," Wirtschaftswissenschaft, Heft 8, 1967.

3. ibid. 
Peter Mandi

THE NON-CAPITALIST PATH AND THE NEW INTERNATIONAL ECONOMIC ORDER

Over the last few years, the topic of a new world economic order has figured on the agendas of many meetings of international politics and scientific conventions. The demands collectively known as the New International Economic order have been ripening for a long time. It was long before the "Year of Africa", notably in 1955, on the occasion of the first large-scale meeting in Bandung of the non-aligned countries, that the seeds of these ideas started to germinate, to become in the brief period of two decades the foci of international economic and political negotiations. The non-aligned movement as a whole, and subsequently the group of 77 , gave a strong voice to the demand of economic independence for the developing countries, first at the UNCTAD Conference of 1964, and then at a succession of other UN conferences. It was these demands that finally crystallized into the charter of the Economic Rights and Duties of states as well as into a number of UN resolutions.

The period from 1955 to 1972 was the phase of preparation of a struggle for a new world economic order; the period since 1973, the phase of attack, has not ended as yet. This attack has by now won considerable ground, and although one cannot as yet speak of definitive breakthrough, two significant results have been achieved:

(1) The former, neocolonialist economic order has been unanimously branded unsuitable and rejected by the Third World.

(2) Negotiations towards a new world economic order have been initiated; by this, the West has de facto conceded the possibility of envisaging an economic order other than the one it has operated over the last few decades in its relationship with the developing countries, to the alleged benefit of those. The Third World, however, preferred to believe its own eyes and the facts that documented the widening of the gap between the developing countries and the advanced capitalist ones.

In this situation there arises quite spontaneously the question: what is the relationship between the non-capitalist way, a systen of the evolution of society distinct from the capitalist one advocated by the West and trending toward socialism, on the one hand, and the demands formulated by the New International Economic Order, on the other. 
In other words, can a connection be recognized between the ideas and the practice of the non-capitalist road and the New International Economic Order?

It is certainly worthwhile to perform an enquiry into this problem, since the internal structure and the international economic relations attitude of any society are closely connected; the two cannot be separated. It is obvious for example that a nation intent on jointly realizing the aims of economic independence and socio-economic progress should strive to build a social structure best suited to these aims, and to bring about foreign-trade relations of a type in harmony with its social structure and contributing to its realization. To a society taking the non-capitalist way it is by no means indifferent whether its participation in world economics will further or hamper the achievements of its social aims.

Among the ranks of former colonies and semi-colonial countries, China, the Socialist countries of Asia and Cuba had turned against the capitalist system; they were separated for protracted periods, or even till our days, from the capitalist world economy, as the capitalist countries had either fully broken or substantially reduced their economic ties with these countries. These countries, then, took a road different both in internal evolution and in foreign relations from the typical road of the Third World countries.

The countries that embarked on non-capitalist evolution did not change their internal social systems as radically as did the aforementioned countries. As far as their international economic relations were concerned, they stayed within the sphere of international division of labour of the capitalist world. Still, their chosen way of internal evolution had repercussions affecting their trade with the West. The advanced capitalist countries exterted pressures upon them, and could by a combination of political and economic means divert a number of developing countries from the non-capitalist road. It has, however, clearly emerged by now that the rights stipulated by these countries for themselves - including the right of the free choice of a social system, state sovereignty over the economy, sovereignty over natural resources, control over foreign capital, the right to nationalize etc. - have become integral parts of the charter.

This close connection between the demands resulting from the essence of the non-capitalist road and the issues raised in the programe of the New International Economic order is by no means fortuitous. On the contrary, both have their common source in disillusionment with the capitalist way and capitalist conditions of the last two 
or three decades. A number of countries are fighting for a new world economic order because they have been frustrated by the neocolonialist order. Those advocating a non-capitalist evolution have been dissatisfied not only in this respect but, going a step further, they even reject the internal economic growth pattern of capitalism. That is to say these latter countries are more conscious: they possess a more advanced strategy of development, whereas the former have been rather pragmatic in proposing progressive practical measures to compensate for the drawbacks of a capitalist-type international division of labour, without a profound analysis of that system and without drawing all the relevant conclusions.

Among the partisans of the New International Economic Order, then, one encounters both the reformers who remain within the sphere of a capitalist order and those who wish to overstep this stage. These latter, however, also support the demands of the New International Economic Order, which opens perspectives of considerable benefit to the Third World, as it would be ill-advised for them to reject these benefits just because they consider the New International Economic Order to be imperfect. They further support it also because a more progressive system of world economy provides, of course, a better springboard for social progress, too.

The demands raised by the non-capitalist countries vis-a-vis the world economy are more stringent than, and in fact, qualitatively different from, the demands of those who tend to adapt to the capitalist order. The relationship of these latter to the advanced capitalist countries is determined by the fact that their internal sociomeconomic order is essentially the same as that of the capitalist countries, and even though they intend to improve their subordinate, dependent position, they wish to do so by means that do not affect the foundations of their social system, and do in fact promote a capitalistic domestic development. Furthermore, it is in the interest of all non-capitalist countries that theix foreign economic policy should reinforce their socio-economic structures of non-capitalist type, instead of driving it back towards a capitalist-type structure. This implies that the non-capitalist countries are more sensitive to influences by institutions alien to their domestic order/such as the transnational corporations/, that they strive more forcefully to restrict foreign capital, and wish to eliminate from their foreign trade, technology transfer and development assistance all those elements that might reinforce the country's capitalist sector.

It is a characteristic feature of non-capitalist evolution that it puts the prime emphasis on the mobilization of internal resources but 
does not expect the mobilization of these resources from a domestic or foreign private capital operating on the profit principle. The measures called upon to develop these resources include the strengthening of the state capitalist sector, state planning, and other levers of state control. Accordingly, their international economic relations are also determined by this attitude; the administration will strive towards a system of international division of labour that reinforces the state sector, and bolsters the state organs controlling the economy. These demands cannot be fully met by a capitalist world economic order, however reformed and improved; this is why the non-capitalist countries will of necessity keep on struggling for more radical changes.

The non-capitalist road, then, means not only that a country wishes to bypass the capitalist period in its internal evolution, but that it strives to do so also as regards its participation in the international division of labour. Now as far as this latter is concerned, the capitalist way in international economic relations is characterized precisely by the contrary, that is, by submitting to dependence on imperialism. The essence of this sort of international division of labour is that the developed capitalist countries create, and the developing countries following the capitalist road tolerate, conditions in which a substantial part of wealth produced in the developing countries is continually siphoned off to the rich, advanced capitalist countries.

The countries taking the non-capitalist road, on the other hand, want to avoid such a transfusion of their wealth, or at least to reduce it to a minimum, recognizing a full elimination of such a transfusion to be impracticable.

In summary, the New International Economic Order such as it has been laid down in the charter and in a series of other documents and declarations, cannot be said to be of a non-capitalist nature. Its stipulations are progressive and in the interests of the developing countries in demands such as the sovereignty over natural resources; the right to nationalize; strive to reduce dependence; control over foreign capital and the transnational corporations, a greater share of wealth generated within the developing countries; conclusion of commodity agreements, organization of cartels etc. These are the demands of capitalist developing countries, too, which strive towards a greater economic independence. They cannot either jointly or severally be considered to constitute a program of socialist or non-capitalist type. This is precisely why the New International Economic Order may serve as a platform for negotiations between imperialism on the one hand and the countries living in neocolonialist dependence on the other. This is no mere theoretical conclusion: it is a fact that these proposals 
have been made by a group of countries most of which chose the road of capitalist evolution; that many a western country took a stand in favour of these proposals; and that some other capitalist countries regard them as partially acceptable; all this goes to show that the New International Economic order envisages a refurbishing rather than the elimination of neocolonialism.

This period has already begun. Tolerance of nationalization has preceded those paragraphs of the Charter that legalize within the framework of international law the transfer of nationalization and compensation into the scope of national sovereignty; improved commodity prices and demands for higher commodity export proceeds have been preceded by the wealth-transfusion act of OPEC, unparalleled in economic history. We are in fact living a new phase of world economic order and may accordingly know from our own experience that the changes achieved represent no revolution against the previous order: they merely represent a reform of the distribution of labour within the capitalist world, in keeping with the new balance of forces between the rich countries and their ex-colonies.

It is nothing extraordinary - in fact, it is a typical historical phenomenon - that radical ideas, much tamed and taken out of their original context, are appropriated and exploited to their own ends by those who at first condemned the initiators of those ideas. Social democracy as a political trend and the social policies of the West as a political practice are good illustrations of how certain important elements of scientific socialism can be turned into mere reforms, to contribute to the preservation, albeit in a modified form, of capitalist society. The fates of the New International Economic Order were much similar. Fifteen to twenty years ago the demands of the charter sounded highly radical and none of today's western countries would have sat down to negotiate on that basis. Nor would the majority of the developing countries have stood for those demands.

Clearly, then, the countries taking the non-capitalist road want to go beyond the order of world economy represented by the charter. What would be the features of a division of labour more appropriate to them, in a world where the major trade partners of the developing countries are still today's rich capitalist countries?

The demands of the countries taking the non-capitalist road vis$a-v i s$ an international division of labour may be derived from the intrinsic nature of the non-capitalist way. Having abandoned the capitalist road, these countries cannot any more expect domestic and foreign capital, operating on the profit principle, to organize their 
economic life and to generate economic growth. This is a task that faces the government as the leading organ of society. True, the economic power of the government is on the increase in the capitalist countries, too, but this is a mere superficial resemblance. The role of the administration in a non-capitalist country is qualitatively different. Relying on the state sector, and employing the means of medium- and long-range economic planning, it takes over the control of the economy and, by the same token, shoulders also the responsibility for economic growth.

The type of international economic relations which is favourable to such a country is that which can be geared to the needs of an economic management operating according to a plan based on long-range foresight. Even in its present form, the New International Economic order has enhanced certain tendencies towards this: the agreements to regulate commodity trade are intended to stabilize export proceeds over long periods of time. The consequential extension and completion of this trend demands the planning of foreign trade volumes, not realized anywhere so far except in trade among socialist countries. This is not surprising since it is the countries regulating their internal economies according to a plan that as a matter of course strive most consequentially towards planned foreign trade relations.

The administration of a country choosing the non-capitalist road and regulating its economy according to a plan will tend to purposefully restrict the drawbacks resulting from the unequal distribution of economic power, to reduce to a minimum the price of backwardness and dependence. It will strive to eliminate every mechanism suitable for siphoning off resources into the advanced capitalist countries. This is what determines its attitude towards foreign capital and to the capitalist sector within the country; this is the guideline of its policy of industrialization.

If the international economic order were to develop in this direction, this would inevitably augment the say of governments in the organization of an international division of labour. It would also favour the non-capitalist countries, because a government with an eye on both political and economic goals will as a rule soonex achieve an understanding with another government than with a corporation motivated by the profit principle. Non-capitalist countries must accordingly strive for a world economic order in which economic independence can under the given conditions be achieved in the most efficient possible way, and planning can be made to prevail in the international division of labour, too. All the other features of such an order can be derived from these. They include bilateral or multilateral regulation of the 
essential processes of the international division of labour, the planned augmentation of export proceeds, planned imports, the ensuring of systematic long-range development assistance; all of these would represent a determined realization of economic independence and planning in the international division of labour.

This is, of course, still an irrealistic demand as of today. It would nevertheless be wrong to regard as utopistic the statement that planning will in time penetrate international economic relations, and that this idea is already ripening in our days. The acceptance of the two successive UN Development Decades is an expression of the intention that the Third World should overcome backwardness in virtue of its own efforts, and with assistance from the international community. The two Development Decades could have become a rational programme precisely if, instead of exercises in arithmetic that did not obligate anybody to anything, they had been based on plans encompassing more or less well-outlined, internationally accepted obligations. Another proof for this ripening is that planning has by now won acceptance in most developing countries and even in the international institutions functioning under a capitalist-bourgeois influence. True, the planning idea is confined to within individual national economies. From there, however, it takes only one step for the developing countries, so sensitive to foreign economic relations, to recognize the necessity of planning in their international relations, too. This would not, of course, be on the level of planning in a socialist world economy, but it would still be preferable to the present system; it would give more assurance to the developing countries, and would render the ways in which the world. economy operates upon the Third World more easy to overview and to control.

International public opinion has begun to realize that overcoming backwardness is a global world problem. This realization may contribute to an ever broadening acceptance of the idea of coordinated rational, planned action in international economic relations.

The advanced capitalist countries will of course strive to realize an international division of labour as favourable as possible from their point of view. They will object to anything tying their hands or giving an insight into the exploitation mechanisms of international economy. Developing countries following the capitalist way are inclined to adapt themselves for the time being and be satisfied with the concessions contained in the New International Economic order in its present form. The importance of the non-capitalist countries, however, is on the increase in both the political and the economic sphere. Their influence upon the rest of the Third World will also grow. These 
countries have a clearer understanding of the essence of capitalism; they are more conscious in assessing the behaviour of the imperialist powers; they are accordingly in a better position to predict processes of world economy and to develop proposals serving the interests of all developing countries. The objective demands of their society and of their society and of their internal economic structure enable these countries to fulfil a historic task. Just as before, these countries will constitute also in the future the spearhead of the struggle for more favourable, more equitable, conditions for the Third world and for the initiation of a progressive world economic order. This international economic order would assign to planning a well-defined part in the development process. 
Jeremy Gould \& Riltta Eaunonen

PITFALLS ALONG THE NONCAPITALIST PATH - COMMENTS ON THE

GENESIS OF INDIGENOUS CAPITAL IN AFRICA

Subsequent to the colonial conquest of Africa, the development of the societies of this continent ceased to occur as a natural historical process. This is the essential factor which distinguishes the development of the social processes in the Third World from those among the West European peoples during the comparable stages of evolution of the productive forces. The production relations grafted onto African society by colonial intervention were essentially alien to the African social environment, and resulted in -- as Tamas Szentes, among others has said -- "distorted" social formations. But a still more decisive difference between contemporary African development and the "classical" path traversed by the developed world stems from the fact that African states are obliged by the realities of the modern world system to cast their lot with one or the other of the major social forces of our epoch -- capitalism or socialism -- despite the fact that the classes which have traditionally constituted the motive forces for each of these tendencies are, in Africa, far from acheiving the proportions associated with either of these social formations.

Consequently, two factors common to nearly all Third World countries - the underdevelopment of the productive forces sired by colonial exploitation, and the urgency of choosing a "path" or strategy for overcoming this underdevelopment -- have brought about the emergenc of the state not only as an uncommonly central political force in the direction of the social processes, but increasingly in the period of independence as the major economic force in the manipulation of the relations and forces of production. The unavoidable consequence of all these factors has been then the emergence of political ideology as a truly predominant social force and the rapid heightening of ideological aspects in the struggle of various classes and strata for state power.

Herein lies the key to understanding the problem of non-capitalist development, both as a theory of social processes and as a contemporary phenomenon. At the same time it should be noted that the realization of the exaggerated position of state control and with it of ideological factors in determining the content of development, places development theory and research in a particularly strategic - and delicate - 
position. As has been repeatedly pointed out in the international working class movement, increasing state interference in the socioeconomic processes must be met with resolute class action on the part of the laboring strata. The expanded influence of the state contains the danger of "lifting" the control over the social processes completetly out of the reach of the people, true, but it also conversely broadens the possibilities for the conscious shaping of production relations according to popular, democratic ideals. It is the social orientation of the state development policy either toward the consolidation of capitalist relations, or toward creating the prerequisites for socialist construction, which is decisive. Research, armed with a scientific understanding of the tendencies moulding the social processes must come to grips with this challenge. In this situation, democratic social science sees as its task to come to the aid of the class struggle of the exploited peoples, helping to pinpoint compromises with imperialism in state and local policy, and to assist the progressive forces in charting out their strategy for socialist-oriented, non-capitalist development.

The purpose of this paper is to attempt a modest contribution to this task by analyzing the some of the possible sources and structures of capitalist development in sub-Saharan Africa. Our emphasis will be on the internal processes connected with the reproduction and accumulation of indigenous capital, primarily in the rural community. This, of course is only one aspect of one side of the story, albeit in our opinion a very central one. So as not to overly "bias" our perspective, however, we must come to the agrarian social formations of Africa via an examination of the basic trends in the imperialist system, especialIy with an eye to the specific role the reactionary forces of international capitalism have devised for Africa in the present era.

\section{The role of Africa in the international capitalist}

division of labor

In order to understand the forms and logic of capitalist (and noncapitalist) development in contemporary Africa we must see the question in a broad perspective, that is, we must examine the changing position of Africa in the international division of labor and in the transient spheres of power relations. The disintegration of the colonial system has had an important effect on the reorganization of internal relations, but at the same time decolonialization was an expression of changing relations -- above all of the deepening of the crisis of modern capitalism. 
The neocolonial division of labor is an integral continuation of the now absolete colonial system of forms of dependence and exploitation. Both the colonial and the neocolonial systems of the division of labor had as their basis the export of investment capital, i.e., the direct investments of foreign capital. I International monopoly capital has nonetheless been forced to accommodate itself to new conditions, which seems to be bringing about a change in the traditional division of labor. T. Szentes notes that to understand the nature of neo-colonialism it is important to investigate the (shifted) investment activity of foreign monopolistic capital, its orientation, motivations and actual or foreseeable socio-economic consequences. ${ }^{2}$

It is important to analyze the objective laws of reproduction in the developed capitalist countries, the changes caused by the scientific and technological revolution (STR) in the industrial structure of these countries, and the new phenomena in the export of capital connected with "industrial neo-colonialism", as I. Mileikovski has pointed out in a discussion of the nature of neo-colonialism. ${ }^{3}$ In the same forum, V. Tyagunenko characterized the formation of a new division of labor like this:

Whereas only recently the neocolonialists sought to prevent the industrialisation of the Third World, now they try to keep it in scientific and technological dependence.Formerly it was the industrial west and its agrarian raw materials appendage - the developing countries that contraposed each other. Now the neocolonialists want to contrapose the industrial-agrarian young states to the technico-scientific West. ${ }^{4}$

These interventions call our attention to a very central point, i.e., the role of the STR in the formation of a new division of labor, as well as the potential for a certain type of industrialization for the developing countries inherent in this division of labor. The STR is connected with the general development of the productive forces, which can be seen as the foundation of the new system of division of labor, along with the related increasing interdependence of nations and the growing internationalization of production. The capitalist character of the process of the development of the productive forces in the imperialist system can be seen in the growth of the influence of the international monopolies as well as in the exacerbation of the contradictions within the system.

E.A. Tarabrin has elaborated upon the interimperialist contradictions in the current era as well as their new distinctive features. First of all, they are conditioned in their development by the basic contradiction of our times, that of the increasing influence of the socialist world system on international relations. Secondly, the STR exercises a tremendous influence on the processes that prevail in the 
capitalist world. This opens the door for an increase in the rate of industrial growth, but at the same time, it widens the gap between the scientific and technological development in individual capitalist countries, resulting in increasingly uneven levels of development. Thirdly, modern capitalism is state monopoly capitalism -- the active participation of the state in the reproduction and accumulation of capital has developed in response to the general crisis of monopoly capitalism. (This does not imply however that state monopoly capitalism has been able to resolve the crisis of capitalism, on the contrary). 5 According to Tarabrin the present stage is a particularly clear illustration of Lenin's law of the spasmodic and uneven development of capitalism.

Two contradictory tendencies influence the development of the leading capitalist countries on the basis of these new features. On the one hand, as indicated above, the imperialist camp is disintegrating: new centres are emerging (in addition to the USA, the EEC and Japan), and the power of the transnationals growing (the MNCs are one of the major sources of interimperialist contradictions due to their limiting effects on national sovereignty). On the other hand, one can observe the tendency toward the integration of forces, eg., via military and economic alliances. At the basis of this unity Tarabrin sees capitalist class solidarity, which manifests itself, for example in relationship to the national liberation movement. Imperialist powers "hold identical views on the strategy for pushing the Third world along the road of capitalist development. These common aims determine the essence of neocolonialism and its methods. of expansion". ${ }^{6}$ Nevertheless, the conflicting interests of the imperialist centers here, too, rise to the surface:

"The imperialists have to compete ever more bitterly among themselves for the narrowing spheres of influence in the Third World, which remains one of the principle sources of profit for the capitalist states. The struggle rages around these countries' "reserve markets", capital investment spheres and sources of strategic raw materials, as well as for political and ideological influence."7

This competition is directed also - today we could even say especially - toward Africa. Consequently, the reorientation in the investment policies of international capital mentioned above are also effecting modifications in Africa's position in the context of a new neocolonial division of labor. ${ }^{8}$ Changes are occurring both in the sources and destinations of investment as well as in the choice of technology. The growing internationalization of the production process is the determining factor in the new division of: labor. 
The traditional colonial powers, France and England are losing their monopoly positions in the capital markets of African countries, especially to the Us, which assumed the leading role in the capitalist world after WWII. Furthermore, colonialism has adopted a new, "collective" form:

Considerable changes have taken place also in respect of the origin and character of foreign capital in Africa. The monopolistic position of the former colonizers' capital has been increasingly replaced by the - less exclusive - dominance of multinational corporations, international monopolies, leaving more place in their service, but less independence, for local enterpreneurs and others, and reflecting the growth of a "collective" neo-colonialism, and the aspirations behind it of US monopolies to "take over", as well as the need for new methods in the era of national independence, and "East-West competition".9

Without going any deeper into the question of transnational corporations, and the vertically integrated industry typical of their activities, nor into the type of industrialization encouraged by the new division of labor in general, it is nonetheless important to emphasize the significance of examining to what extent the investment policies of international monopoly capital in the long run influence the prospects for the formation of a national mechanism of reproduction, as well as for such industrialization as would facilitate the reproduction of capital on an expanded scale in African developing economies. To what extent do the strivings of imperialism to engender capitalist development merely lead to "growth without development". As we pointed out above, these questions will be resolved to a large extent by the role of the state, that is, to what degree, for example, the indigenous petty-bourgeoisie assumes the role of an intermediary between the imperial system and the domestic social formation, one of the cornerstones of the current division of labor. The exacerbation of political contradictions, however, reflects the disintegration of this system and perhaps gives cause to infer that "in fact the imperial linkage is not so neatly facilitated nor so smoothly functioning as is sometimes assumed. There are real difficulties in guaranteeing the stability of the peripheral capitalist system and in ensuring the further reproduction and accumulation of capital. The state has not always effectively played its role in accomplishing these tasks". 10

The articulation of the specific inter-relationships between the processes of reproduction and accumulation of capital in the "center" and in the "periphery" of Africa, then, provides an urgent task on the scientific front in the anti-imperialist struggle. The following intervention however, will not deal directly with this articulation, per se. Instead, we hope to make a contribution toward clearing up some theoretical and methodological ambiguities which have played a highly 
distractive role in many attempts at the elaboration of these 'macromicro' relationships thus far. These ambiguities relate primarily to the way in which researchers conceive of the "domestic social formation" and of the role and process of the genesis of capitalism therein. We will therefore limit the scope of our remarks to the internal aspects of this process in sub-Saharan Africa, even at the risk of exaggerating the weight of specific national-level factors in relationship to the general international tendencies. We are nevertheless aware of the limitations that this perspective places on making any far-reaching conclusions, nor is this our purpose. We will be satisfied if we can, even in the context of this very preliminary analysis succeed in playing a clarifying role regarding the way in which the questions in this area of analysis should be stated.

The method of political economy and multistructural formations

A comparison of conceptions of the process of capitalist development in Africa leaves the student with quite contradictory impressions. Even when the survey is limited to more or less Marxist writings, one finds that conclusions are often quite divergent, even when the observations concerning the specifics of the process themselves are quite similar. Thus, we find that some writers, in attempting to dispense with the "classless Africa" -fallacy, tend to see the buds of capitalist class contradictions bursting into bloom in every sector of the economy. Conversely, there is no shortage of examples of authors, who, when arguing on behalf of the necessity for African states to disengage themselves from the capitalist world system and to instigate policies characteristic of socialist orientation, end up claiming that the development of an indigenous capitalist economy is a virtual impossibility.

Perhaps this trait can be chalked up to a kind of ideological propriety among self-fashioned radical social scientists. C. Leys, however, seems to sense the existance of theoretical-methodological ambiguities at the root of the problem:

"Underdevelopment theory does suggest reasons why, in many Third world countries, capitalist development has not followed and will not follow the same sort of course, or with the similar social and political consequences, as it did in the advanced metropolitan countries; but it does not show that no capitalist development can occur in them at al1..."11

The reason that "underdevelopment theorists" are not able to take a definitive stand on this point, aside from certain deficiencies in empirical data, is that they lack a formal theoretical elaboration of the process of the circulation and reproduction of capital in postcolonial multistructural social formations of Africa, ${ }^{12}$ creatively manipulating the categories introduced by Marx and applied by Lenin to turnof-the century Russia. 13 
The main reason for this lack is most likely the relative recentness of the "rediscovery" of Marx in the West combined with the long-term isolation, by colonialism, of Africa from the main centers of the development of Marxist-Leninist theory. Be this as it may, there seems to be an unoverlookable gap in the analytical arsenal of Marxist theory of Third World processes, at least among western scholars. We call attention to this here precisely because we suspect that an understanding of the laws of motion of capitalist development are an essential (if not sufficient) condition for the understanding and successful implementation of a non-capitalist development strategy.

Nevertheless, it is not our intention, nor for that matter in our powers, to attempt even the most rudimentary outline of formal assessment of the circulation and reproduction processes in contemporary African societies. Rather, this section will be limited to a discussion of some of the major qualifications which the concrete historical and cultural situation in Africa today places on the direct application of the methods and hypotheses used by Marx and Lenin in mapping out the laws of the development of capitalism starting, as they did, with rural agricultural structures. We will then attempt to cash in on any insights gained during a brief, if critical round-up of some central themes in the controversy and prevailing wisdom concerning the genesis of capitalism in post-colonial Africa.

When Lenin approached the question of the spontaneous development of capitalist production in Russian agriculture, his analysis was structured by assumptions relating to two broad problems:

1) the emergence of commercial agriculture based upon commodity production, and

2) the "differentiation" of the peasantry corresponding to the introduction of qualitatively new social relationships. ${ }^{14}$

One must note right off, however, that for Africa both of these developments were part and parcel of the economic policy practiced during the colonial period. ${ }^{15}$ The capitalism of the imperialist epoch did not have, however, the "great progressive historical role"16 that Lenin attributed to the nascent capitalism of 19th century Russia. Especially in Africa, capital left the "revolutionization" of the communal society half-done, resulting in what for example szentes has call "distorted" and Shivji "lop-sided" social relations. This can be seen clearly by how "half-true" Lenin's evaluation that (in Russia)

"capitalism destroyed local seclusion and insularity and replaced the minute medieval divisions among cultivators by a major division, embracing the whole nation, that divides them into classes occupying different positions in the general system of capitalist economy."17 seems when applied to African societies on the eve of independence. 
The reasons for the particular results of the interaction of capitalism with colonial Africa are two-fold (at least). The more obvious factor is the specific nature of the colonial capitalism which did not -- as Rosa Luxemburg would have assumed -- even seek to bring about the "annihilation of every historical form of natural economy that it encountered", 18 but rather "left unchanged and intact and even preserved the remnants of the old mode of production ... in so far as the survival of these remnants did not disturb its own activity, and preserved them as it could make use of them in its own interests". ${ }^{19}$ This process then resulted in the specific mode of superimposition of capitalist relationships upon sundry precapitalist structures, structures that capitalism itself tended to preserve and, consequently, distort, the product of which were the multistructural social formations we have referred to.

But a second factor, highly significant in its ow right, must be sought in the nature of the indigenous modes of production which confronted the imperialist expansion in Africa. Clearly the characteristics of African production systems, especially regarding land ownership, systems of co-operation, patterns of trade and so on, were quite unique compared to the societies colonizers found in other areas and, it seems justified to assume that the merchant capital which colonial expansion predominantly generated in Africa (the slave trade, ivory) did not differ much from the higher forms of industrial and finance capital in their effectiveness in transforming precapitalist modes of production:

"To what extent they (commerce and merchant capital) bring about a dissolution of the old modes of production depends on their solidity and internal structure. And whether this process of dissolution wili lead, in other words, what new mode of production will replace the old, does not depend on commerce, but on the character of the old mode of production itself". 20

A growing realization of the significance of the structure of indigenous modes of production in determining the character of contemporary post-colonial social structure has generated a lot of research activity especially among scholars working in the anthropological tradition. Thus Maurice Godelier ${ }^{21}$ declared the uncovering of the elusive "internal logic" of precapitalist modes of production as a top priority for Marxist research, while others have participated in a crusade for a "theory of the mode of production" which would similarly elucidate the subtleties of "primitive" social structure. Much of this controversy has been more than slightly tinged with ahistoricism and Althusserian metaphilosophy, and has, paradoxically generally failed to address itself to the concrete case of the (distorted) intermingling of modes of production characteristic of the African multistructural 
formation. A fair example of this is a recent article by $w$. Roseberry on the exploitation of the peasantry. ${ }^{22}$ Roseberry's piece is interesting in that it is a rare attempt by a Western Marxist anthropologist to propose the use of Marxist categories describing the historical evolution of the forms of excess surplus value. But even though Roseberry claims to ascribe to the thesis that "unquestionably, the main problem faced today by anthropologists ... is to conceptualize various forms of articulation of an internationally dominant capitalist mode of production ... with non-capitalist (sic) modes of production, "23 he seems willing to accept the use of the Marxist categories of rent without inquiring (or even "conceptualizing") how the articulation of international capitalism with his peasant societies has historically affected the modes of the appropriation of the surplus since Marx' day.

Already from the above it should be clear that the evolution of the excess surplus value in contemporary Africa does not follow the gradual nor the linear path charted by Marx: labor-rent, rent-in-kind, money-rent. This follows from the fact that communal and other precapitalist structures in Africa today no longer develop of their own momentum toward capitalism and the generalization of capitalist groundrent through the consolidation of feudal types of social relations. 24 The very existence of a developed capitalist market which confronts the "natural economy" in full force precludes the normal evolution of the various forms of the excess surplus value prescribed by Marx. On the contrary, the widespreadoccurrence of alliances between big foreign and later national capital with the emergent "rural bourgeoisie" (if we can use this denotation) and its feudal and semi-feudal predecessors, can tend to "freeze" the development of the form of "rent" and its mode of appropriation according to the needs and strategy of capitalization (as the quote from Szentes above hinted).

Consequently, the apparent, observable forms of rent would not seem to be very reliable indicators of the development of capitalist relations, nor subsequently of the degree of exploitation of the peasant. It is essential to look beyond these forms, at their content, above all to the role a particular form of rent might play in the total reproduction process of capital. Faced with instances of, for example, wage labor in peasant agricultural production, we must ask, are the constant and variable capitals thus being utilized, and the surplus value thus being produced integral elements in a process of extended reproduction, i.e., has the "employer" hitched his hired labor to a wagon which is carrying them through a cycle of capitalist accumulation, or does the use of money in the exchange perhaps merely "mirror" the general image of the expanding capitalist economy, i.e., is it merely 
grafted onto some form of (perhaps imbalanced) reciprocity ${ }^{25}$ relation the roots of which are still deep in the communal past. ${ }^{26}$ Similar questions must be proposed regarding several other categories e.g. labor rent and rent in kind, simply on the basis of certain historical and cultural idiocyncrasies of that continent.

But more important, in this context, than poring over this or that isolated element of a potential political economy of African capitalism is to discuss the methodology of this field of research as a whole. We are not in a position to propose far-reached solutions to this set of difficult problems. Hopefully, though, we can succeed in posing the correct questions in a way conducive to collective consideration.

What then, we should inquire, constitutes the optimal mode of research for "looking beyond" the surface of socio-economic phenomena in African multistructural formations and for unravelling their essence. In its general form, it could not diverge greatly from the general analysis of the classics of Marxism-Leninism, and might be seen to consist of hypotheses regarding the following four points:

$1^{\circ}$. The social relations involved in the production of commodities (and their evolution);

$2^{\circ}$. The circulation of commodities and the forms of value they assume therein;

$3^{\circ}$. The process of the reproduction of the capital in the circulation cycle; and

$4^{\circ}$. The reproduction of the social relations in the circulation process. 27

One extenuating factor in this model is of course the multitude of modes of production and social relations which must be taken into account. In spite of the underdevelopment of the domestic market, various phenomena, of which labor migration is the most exacerbated, demand that such an analysis of circulation and reproduction take place (at least hypothetically) over the entirety of a national economy or discrete economic region. This requires that research encompass a huge variety of different capitals, immensely diverse as to form and structure, including a large proportion (foreign capital) that are principally actors in a reproduction cycle in which the national African economy is only a "peripheral" link. The methodological problems implied by this (i.e., the internationalization of production in general) are very complicated as is well known. From our point of view, the central dilemma is to determine to what degree apparently indigenous capitalist relations can be seen to be generated "solely" by the circulation of foreign capital, and more complicated still, to evaluate to what extent 
the motive forces of the indigenous capitalism so generated are capable of continued autonomous development on the basis of their accumulated "inertia", in the event that a state of socialist orientation disengages itself from the world capitalist system.

However, the answer to such speculative questions already requires a profound understanding of the specific structures of emergent African capitalism. Lenin was firm on this point:

"Before attempting to describe the reproduction and circulation of the product which is produced in agriculture capitalistically, one must first ascertain exactly how and to what extent agriculture becomes capitalist. 28

Thus we are back once again with the question of the actual extent and process of capitalization in sub-Saharan Africa. Now we are perhaps in a better position (methodologically) to assess some of the divergent stands in the controversy.

Unfortunately, we cannot compare studies on the processes of circulation and reproduction as outlined above, inasmuch as this way of stating the question has not structured the bulk of research in the field of African political economy. Hence we must attempt to substitute analyses of the evolution of the class structure of African social formations for the more rigid examination indicated. The focus of our attention in this comparative discussion remains limited to the genesis of capital in rural structures.

As a point of departure, let us adopt $R$. Stavenhagen's following observation:

"Fully established class structures are not yet found in the African countryside. Many traditional structures have begun to be modified, while the new structures which have grown out of the development of capitalism are still in the process of formation".29

Given this transient nature of class formation, the main question is of the direction and dimensions that this extant capitalization will acquire. Can this current development result in the consolidation of a breed of viable indigenous capitalist structures and respective classes in the rural areas, or will the 'dependent' or 'peripheral' character of African capitalism continue to assert itself? In either case, this would have far-reaching ramifications for strategies of socialist orientation, not least of all in the ideological sphere, the predominance of which we alluded to earlier.

We will survey various opinions on this issue in relationship to three generally discussed characteristics of the capitalization (i.e., class formation with many writers) process: 1) the role of commodity production and exchange, 2) labor migration, and 3) rounding up our analysis, the motive forces of capitalist development. 30 


\section{Role of commodity production}

The existence of commodity production is certainly a precondition if not an indicator of the development of capitalist relationships. As Amin points out:

"Monetarization is an absolutely indispensable preliminary condition for the appearance of the capitalist structure. Simple commodity economy, once engendered, will inevitably result in the ruin of some and the enrichment of others; in other words, in the formation of indigenous capital. This is an absolute law".31

However, while it might well be that this "absolute law of the transformation of simple commodity economy into capitalist economy ... is not the last word" concerning the development of precapitalist formations, there should be no doubt that the development of commodity exchange is a significant occurrence in the evolution of rural formations, regardless whether this is seen as a positive historical event or not. The appreciation of this fact, however, requires the recognition of the central role that the fate of pre-capitalist structures plays in the future of Africa.

Surprisingly, I. Shivji, An criticizing M. Mbliniyi's paper on "The transition to capitalism in rural Tanzania" 32 rejects the significance of commodity exchange as "a necessary step in the transformation of precapitalist production systens into capitalist or socialist ones" as a "non-issue". This he does on the basis that Tanzania is "neither pre-capitalist, nor capitalist (developed) or socialist, nor is being transformed from pre-capitalist to either capitalist or socialist." Rather, Shivji sees Tanzania, along with most of Africa as "an underdeveloped capitalist society within the world Capitalist system". ${ }^{33}$

Here Shivji demonstrates a telling inconsistency regarding his conception of African social structure. Earlier in his book when presenting his thesis of the dominance of the capitalist mode he points out: "This is not to say that there are no other modes of production side by side, but they are subordinant to the dominant (i.e., capitalist) mode". And later: "So-called capitalist development has in fact meant the conservation of the old forms -- in some cases feudal and semi-feudal -to serve new ends." ${ }^{34}$ Clearly, the fact that pre-capitalist structures are seen as subordinant to the dominant, capitalist mode can not rob them of their essential character. If it did, by what criteria could they be categorized as other than capitalist formations?

Shivji's confusion in this connection (in which he unfortunately is not alone) stems from a propensity to somewhat mystify the world capitalist system (hence the capital letters?) apparently making a clear evaluation of the balance of class forces, and consequently an under- 
standing of the potential for non-capitalist development nearly impossible. ${ }^{35}$ Inasmuch as Shivji's book is among the only theoretical analyses by an African of Marxist orientation to find its way into the world market, we will allow ourselves a brief detour from our main line of argument to call attention to this fact.

We have no intention of taking shivji to issue for this pointed critique of petty-bourgeoise tendencies in Tanzanian state and party leadership. These may be quite justified and could be quite to the point, especially if it were tied in to that experience which shows how "progressive regimes may fall when they have underestimated the strength of the so-called new-bourgeoisie who oppose socialist orientation". 36 However, even on the basis of Shivji's own exposition, his thinlycloaked invocations to peasant-based revolution under the leadership of "proletarian ideology", do not appear to reflect sober political analysis of the Tanzanian situation.

"Experience in Africa has proved over and over again that talk of alliances and fronts between proletarian, semi-proletarian peasantry, revolutionary intelligentsia and so on, can only have real meaning if the working people are able to express themselves organizationally and politically".37

Shivji's apparent desire to see an intensification of the class struggle lead to an ousting of the "bureaucratic bourgeoisie" and its replacement by a "worker-peasant alliance" cannot in itself be criticized. Nevertheless Shivji should be aware that the non-capitalist way is a "course of persistent class struggle where victory may be laced with defeat ... (it) may also be cut short as a result of 'Leftist excesses', attempts to carry out socialist transformations without the necessary prerequisites" as occured in Mali in 1968. 38 Here too, Lenin's words are a timely reminder for revolutionaries confronted with the unprecedentedly difficult task of waging class struggle under conditions of non-capitalist development:

The greatest, perhaps the only danger to the genuine revolutionary is that of exaggerated revolutionism, ignoring the limits and conditions in which revolutionary methods are appropriate and can be successfully employed. True revolutionaries have mostly come a cropper when they began to write 'revolution' with a capital $R$, to elevate 'revolution' to something almost divine, to lose their heads, to lose the ability to reflect, weigh and ascertain in the coolest and most dispassionate manner at what moment, under what circumstances and in which sphere of action you must act in a revolutionary manner, and at what moment, under what circumstances and in which sphere you must turn to reformist action". 39

This in absentia polemic with Shivji is far from an exhaustive inventory of the issues surrounding the question of the role of commodity production and exchange, but it does bring up the most important point, i.e., that seeing the capitalist mode production as the dominant mode 
in a given social formation can lead to serious theoretical difficulties, especially in the analysis of transitory phenomena common to several systems of production relations, if dominance is understood as total pervasiveness. Szentes' perspective, while coming close to this approach, retains an element of class dynamics in the countryside which seems conducive to a more subtle analysis:

"In the underdeveloped economy inherited from colonialism, the predominant production relations are de facto capitalist relations, under the influence of which the surviving pre-capitalist relations, too, carry in themselves the tendency of capitalist development". 40

In contrast to Szentes' ideas, the collective Soviet authorship of the recent monograph The Developing Countries: Regularities, Tendencies, Prospects states quite unequivocably that

"it is incorrect to identify the disintegration of the community and the beginnings in it of a private sector with capitalist development... the capitalist transformation of the African community is possible only through a series of transitional stages and only in a developed capitalist environment". 41

For these scientists, then, the typical characteristic of rural African development in the current period is that

"the agrarian economy is passing through the agonising stage of slow and uneven transition from a natural economy to commodity production".

Nevertheless, "most of the small farms that account for a substantial part of the commodity production of the countries in question are not ... marketable farms in the real sense of the word, that is, farms developing on the basis of the law of value". 42

It is not our responsibility here to resolve the problem of whether small-commodity production in the context of pre-capitalist agrarian formations can "carry in itself the tendency of capitalist development" irrespective of the law of value. Such an analysis would take us far afield from our proposed discussion outline and lead us, we suspect, into an in-depth exanination of the nature of state capitalist intervention in the agricultural sector of African economies. Instead we leave the consideration of this dilemma at the reader's discretion preferring to take up a phenomenon which many have considered the main mediating factor in the genesis of indigenous African capitalism: migratory labor.

The social position of the migrant worker

There is little disagreement about the fact that labor migration on the scale to be found in contemporary Africa is a concomitant of the forced implantation of labor-intensive capitalist enterprise (largely mining and plantation agriculture) on the part of big "metropolitan" capital. 
This was generally complemented by a conscious colonial policy aimed at introducing economic (and when often necessary extra-economic) "incentives" to "liberate" the indigenous African population from its predominantly subsistence-oriented system of production. Nor is there much controversy regarding many of the major ramifications of this "depeasantization" process for the "natural economy":

"The migrations of rural populations ... take place within the changing economic processes which liberate manpower from the areas of subsistence agriculture and draw it into the money economy".43

This monetization of the rural community, as noted earlier, implies the de facto expansion of the sphere of circulation of (primarily) industrial capital, which for its own part facilitates the general process of the accumulation and concentration of capital, also in the rural community. ${ }^{4}$

The migrant is also seen as an arbitrating force between the "traditional" and the "modern" spheres of the multistructural formation in another sense, as a vehicle of the experiences of the proletarianized urban industrial and capitalist plantation-agricultural working strata. ${ }^{45}$ Such a dual character has caused many to ponder, as has M.I. Braginsky: "What is the social status of the African migratory worker? Is this group to be categorised with the working class or the peasantry". ${ }^{46}$ To this same point of departure, M. Mbliniyi connects her observation (corroborated among others by Shivji and Szentes) that "some proportion of (migrant) blue collar workers of all types ... exploit the labour of others on their farms" in their home community. This leads her to formulate the question more pointedly:

"Is a blue collar semiskilled worker who runs his farm on the basis of hired labour ... a member of the proletariat or the rural bourgeoisie (assuming he is among the rich peasant strata at the rural location of his farm)?"47

Clearly, a response to this riddle must be sought concretely, through an empirical definition of the "role of hired work in the African land-tiller's life". 48

For such an analysis Charles Elliot's distinction between four basic categories of migrant labor seems very informative. 49

Elliot distinguishes first of all between what he calls "temporary" and "permanent" migratory laborers. Within both categories he further discerns two sub-divisions: among those rural inhabitants only engaging in wage labor on a temporary basis at a given time, he sees, on the one hand, migrants taking occasional jobs off their own farm merely to supplement an already sufficient subsistence with extra cash, and on the other those peasants forced for various reasons to 'moonlight' in 
the wage sector in order to eke out a subsistence (we might call these "voluntary" and "obligatory" migrants respectively). Within the sphere of "permanent" migrants, Elliot distinguishes between "settled" laborers -- the minute group of mobile laborers with a continuous job, as domestic-laborer, hired hand or the like -- and "casual" migrants -the more or less classical case of a worker constantly on the move from one seasonal engagement to another. 50

Least we provoke needless protests from methodological purists, let us reiterate that such a classification system has nothing in common with the epistemological rigor on the behalf of which we proselytized earlier. Nevertheless, such a taxonomy, being in close proximity to the "surface" of social reality, has the advantage of defining "emic" boundaries between groups of migrants, i.e., distinctions close to the experience of the worker himself. ${ }^{51}$ Hence even on the basis of such a "vulgar" classification, it is plain to see, especially when the ideological dimension is given special consideration, that only for two of the four sub-divisions, the "obligatory" temporary migrant and the "casual" permanent laborer, is the proletariat-bourgeoisie dilemma problematic. 52

With a little intuition one can envision these two types of migrant labor as different degrees in severity of the same phenomenon: the intensifying disintegration of the agrarian community on the crest of monetization, perhaps exacerbated by increased economic and/or ecological pressures. It seems, then, reasonable to assume that the majority of those rural inhabitants successful enough in their utilization of the proceeds of sojourns into wage labor to risk being classified as "rural bourgeoisie", originate nonetheless from circumstances of acute rural poverty. The question that must be put then is how does their participation in capitalist production affect their relationship to "native" agrarian structures, both subjectively and objectively.

The initial accumulation process leading to the birth of a nouveaurich peasant entails much hardship not to mention confrontation with the most heightened inequities facing working people in all sectors of the underdeveloped economy. Should this migration cycle need to be repeated (as Woddis indicates and stavenhagen confirms) ${ }^{53}$ this should definitely weaken the potentiality of ideological alliances with overtly anti-popular forces, even in the event that the migrant-turned-entrepreneur employs hired labor (and note the problems in the interpretation of this category mentioned above). However, given a fertile augur for the investment and expanded reproduction of the initial capital, i.e., access to land, a favorable market situation, availability of labor and technology, etc., identification with the semiproletarian past may be 
quick to fade in the manner of self-made capitalists everywhere. Thus the criteria for the "categorization" of rural entrepreneurs (a point we will return to soon) must be taken from the specifics of the social situation under analysis. Not, however on solely the basis of criteria such as income or status as employer, but regarding the broader spectrum of his role in social life, the place he holds in the system of production. 54

All this being said, the question still remains of how migratory labor relates in general to the process of the development of rural capitalism, and specifically, of the position of the migrant to capitalist production and the formation of its two main antagonistic. classes. To deal with this we need a somewhat different conceptual framework, one related to the identification of the motive forces of capitalist development. This is the topic of the next, concluding section of this essay.

\section{The motive forces of indigenous capitalism}

In a discussion paper like this, one can at best hope to scratch the surface of such a complex set of processes as constitute the genesis of African capital in rural structures. Nevertheless we feel obliged to attempt to gather together some of the various threads we have spun through the preceding pages in an effort to make a concluding statement regarding the identification of the motive forces of potential capitalist accumulation, in the spirit of our opening remarks.

There were cextain questions posed in this essay - such as that of the relative autonomy of indigenous capital and the tendency of development of contemporary pre-capitalist structures - that we felt were best left open. Others - most notable the role of the state and other political structures, the effect on capitalization generated by the transnationals, and the co-operative movement - we simply lacked resources to deal with in this context, grave as the resulting deficiencies in the final (preliminary) product may seem. In any case the following remarks should not be read as an attempt at the creation of new analytical categories for Marxist research on African development. on the contrary, in contrast with the emphasis in the first half of the paper on the objective conditions for the development of capitalism, we would now like to try to briefly formulate a summary of these thoughts in terms closer to the flesh and blood of the class struggle itself, even at the risk of methodological hypocrisy.

Hence, instead of approaching the question of the motive forces of capitalist development as it "should" be - in terms of the various loci of the accumulation of capital during the course of the circulation 
process - we propose to start from the "wrong" end of the ladder, with some comments on the entrepreneural mentality as the single most significant subjective factor in the genesis of capital.

Entrepreneurism is clearly the main subjective vehicle for the expansion of pre-monopoly capitalism, one could say, regardless of historical specifics of the social situation. The law of value dictates this. At the same time, however, it must be admitted that it has also played a certain historical role as an impetus to the development of the productive forces during the transition to socialism in several countries. 55 This dual character of the entrepreneural mentality is important to recognize simply because the predominance of capitalist relationships inherited from colonialism so often finds expression among the remnants of the break-up of traditional structures in just this form. Hence while it might be foolhardy for a regime of socialist orientation to actively engender the ideology of individual enrichment (paradoxical at any rate), a subtle understanding of when and how such a disposition might be harnessed to the development of the productive forces in the support of anti-imperialist and even anti-capitalist struggle, can be a rare jewel of political acumen.

If we attempt to take stock of the contemporary stata and classes in rural Africa on the basis of what has been said thus far, one group seems to stand out in relationship to its position in the process of social production and its propensity toward entrepreneurism: the capitalist tenant. Objective pre-conditions for self-enrichment contrasted with the legislative manipulativity of these conditions (via plot ceilings, state wholesale monopoly, etc.) which could hypothetically, keep the average accumulation rate of commercial tenant farmers within certain more-or-less estimable bounds, makes this class very vulnerable for political manipulation. Neither should it be forgotten that, given favorable conditions, this stratum has historically demonstrated a great dynamism for the adoption of new techniques, while the clientel character of its social position makes tenant farmers in general a potential opponent (if sometimes also an ally) of big capital. Despite its dynamism, however, the commercialized agricultural tenant is very dependent upon the overall economic atmosphere in the country. As Marx pointed out, the dissolution of pre-capitalist patterns of land tenure gives rise to a generation of capitalist tenants "whose development is conditioned by the general development of capitalist production beyond the bounds of the countryside". ${ }^{56}$ Regardless of the direct applicability of this observation, its implications for non-capitalist development deserve to be discussed. 
The elevation of entrepreneurism to the status of a major political resource in socialist orientation is of course as negative an approach as it is (overtly) paradoxical. In any event, its relevance is obviousIy limited to strata that are directly linked to the consolidation of capitalist relationships of production. Certainly other approaches are needed, those related to the forms of social consciousness reflecting the change in the balance of world forces in favor of socialism as well as the rapid process of proletarization in Africa. That is to say, such forms as solidarity, co-operation and internationalism must also be not only "harnessed" but put into the driver's seat. Indeed, in the final analysis the crucial question is that of the social content of political leadership: there is certainly a world of difference between political rulers harnessing solidarity and co-operation in their own entrepreneural self-interest and mobilization on the basis of hallowed principles of toiling peoples everywhere that the forces of exploitation might be given the means of their own demise.

\section{NOTES}

1. Szentes, Tamás, "A New Emerging Pattern of International Division of Labour, with Neo-Colonial Dependence. A Possible strategy to Escape", Conference Paper, 1974 Canadian Association of African studies, p. 17.

2. Ibid.

3. E. Ablina: "Imperialism and the Developing Countries, "Social Sciences" 4/1973, p. 226.

4. Ibid., p. 228 .

5. On the crisis of state monopoly capitalism, see J.0. Andersson: "Neo-colonialism in crisis", J. Käkönen, (ed.): The Mechanisms of Neo-colonialism, Mänttä 1974, pp. 13-16.

6. Tarabrin, op. cit. p. 14 .

7. Ibid.

8. Szentes analyzes the new emerging neo-colonial pattern of investment, but remarks cautiously, that "it is too early to speak already about the operation of a new system of international divisions of labor, particularly in the case of Africa where the elements of the "classic" pattern of extractive imperialism are still predominant (Szentes, op.cit., p. 17-8). Andersson, on the other hand, basis his analysis already on the crisis of neocolonialism.

9. Szentes, op.cit., p. 19.

10. "The State in Africa", Editorial in the Review of African Political Economy, No. 5 (1976). 
11. Colin Leys: Underdevelopment in Kenya. The political economy of neo-colonialism 1964-71. London 1975. Leys refers to the theories epitomized by among others Baran, Frank, Amin, and Saul.

12. On multistructural formations see eg. Levkovsky: The Third World Countries: Their Multiform Economic Structures" Social Sciences 2(4)/1971, pp. 156-64; Ulyanovsky-Pavlov: Asian Dilemma, Moscow 1975, Rastyannikov: Agrarian Capitalism in a Multistructural Society, Moscow 1973 (Russian) a condensed translation, "Agrarian evolution and class-formation processes in India" appeared in Social Sciences, 3/1973, pp. 138-51.

13. Marx: Capital. (notably book II, chapters XX, XXI). Moscow 1967, Lenin: The development of capitalism in Russia, Collected works, vol. 3. A notable exception to this is Khalatbari's formulations in his ökonomische Unterentwicklung (Berlin 1973). Khalatbari's study, however, appropriated in abstract analysis as a dualist model, limits its scope to those formations dominated by "semifeudal" relations. This limits its applicability for the majority of Sub-Saharan African countries, although the methodological significance of Khalatbari's work is obvious. Both Szentes' The political economy of underdevelopment (Budapest 1972) and Tjulpanow's Politische okonomie und ihre Anwendung in den Entwicklungsländern (Frankfurt a.Main 1972) include important elements for the kind of analysis we are alluding to, though neither one quite gets down to "brass tacks". Even Geoffrey Kay's ambitious attempt at a formal elaboration of the political economy of Development and Underdevelopment (London 1975) fails rather sorrily in that it ignores precisely these historical specifities of contemporary i.e., multistructural formations in the underdeveloped world. We are aware that such work has doubtlessly been undertaken by researchers writing in Slavic languages (eg. Rastyannikov, op.cit.) but these are generally inaccessable to our research community for the time being .

14. Lenin, op.cit., see especially chapt. II: "Differentiation of the Peasantry". It should be noted that both of these questions are only meaningful for Lenin in relationship to the underlying theme in his inquiry: the development of a home market to facilitate the national circulation of industrial capital.

15. Ann Seidman gives a concise summary of the policies and their consequences in her "Class stratification and Economic Development in Africa". Pan-Africa Journal, vol. V, no. 1/Spring 1972.

16. Lenin, op.cit., p. 316.

17. Ibid.

18. See Rosa Luzemburg: The Accumulation of Capital, London 1971 (1913), Section III. For critiques of Luxemburg's theoretical misevaluations see B. Bradby: "The destruction of the natural economy" Economy and Society 2/1975, pp. 127-60; J.0. Andersson: Studies in the Theory of Unequal Exchange between Nations. Abo 1976.

19. Szentes, op.cit., p. 152 .

20. Marx: Capital III, p. 312 .

21. M. Godelier, Rationality and Irrationality in Economics, London 1972 . 
22. Willian Roseberry, "Rent, Differentiation, and the Development of Capitalism among Peasants", American Anthropologist, vol. 78, no. 1 (March 1976), pp. 45-58.

23. Berthoud, G., "Dynamics of Ownership in the Circum-Alpine Area", Anthropological Quarterly 45 (1972), p. 118. (cited in Roseberry, ibid.)

24. Khalatbari is perhaps of a different opinion on the role feudalism is still to play: "Die herausbildung des Privateigentums tendiert jedoch nicht zu kapitalistischen, sondern zu halbfeudalern Verhältnissen, die als "Ubergang zum Kapitalismus betrachtet werden können". (Khalatbari, op.cit., p. 118). Szentes, on the other hand, leans to the interpretation presented here (see below).

25. On reciprocity and its origins in primitive formations see Sahlins, Stone-age Economics, New York 1972.

26. "The general economic atmosphere in the capitalist-oriented countries gives an appearance of capitalist relations and categories to the relations and phenomena which are similar to capitalist ones in form only". Avakov-Maidanik-Pokatayeva, "Possibilities and Limits of Capitalism in the Third World", Social Sciences, 4/1975, p. 153 .

27. Saith and Tankha have formulated an interesting though somewhat different program for investigating the dynamics of multistructural formations, consisting of three stages:

a) An analytically meaningful characterisation of the complex of production relations prevalent, and the position of the different sections of the community in this complex.

b) To unearth the underlying logic, and analyse the operation in concrete terms of the process of change which transforms the materials and social basis of production from the pre-capitalist to the capitalist ones.

c) To assess the extent to which this process of transition, with its inherent logic, has carried the community towards capitalism.

Saith, A and Tankha, A, "Agrarian Transition and the Differentiation of the Peasantry", Economic and Political Development,

Vol. VII, No. 14, Cited in M. Mbilinyi, "The transition to capitalism in rural Tanzania" Economic Research Bureau Paper 74.7. Dar es Salaam 1974 .

28. Lenin, "Uncritical criticism", Collected Works, vol. III, p. 612.

29. Stavenhagen: Social classes in agrarian societies, New York 1975, p. 92 .

30. We will avoid dealing with one question already mentioned, that of the relative autonomy of indigenous vis-a-vis foreign capital inasmuch as the level of abstraction inherent in this survey is not conducive to a very fruitful discussion of this point. In the final analysis, it is concrete considerations such as relationship to new developments in the home and external market, prospects for reinvestment, access to necessary inputs (materials, labor, technology and finance etc., and not national origin, which determine the autonomy of various capitals in the national economic constellation. This is not meant to imply that there are not systematic discrepancies in the opportunities of indigenous vs. Eoreign capital. On the contrary, but we are not in a position to elaborate them here. Nevertheless, we might add that Amin's distinction 
between economies in which foreign capital directly controls the production process in the main, i.e., export sector, and those in which foreign interests reign via the infrastructure leaving room for local capital to develop might provide a possible vehicle for further discussion. See Amin: Accumulation on a World Scale. New York 1974, pp. 171-3.

31. Ibid.

32. Mbliniyi, op.cit.

33. Issa Shivji, Class Struggles in Tanzania, London 1976. The phrase Shivji cites is apparently from an earlier version of Mbliniyi's paper.

34. Shivji, op.cit., pp. 16, 112 .

35. He admits this inadvertently himself. See section on "Skipping the capitalist stage", especially the incredible reference to "noncapitalist elements" on p. 16.

36. Solodovnikov-Gavrilov, "Africa: tendencies of non-capitalist development" International Affairs 3/76, p. 32.

37. Sol Dubula, "The Congo on the Road to Socialism", The African Communist, no. 64, 1976, p. 46.

38. Solodovnikov-Gavrilov, loc.cit.

39. Lenin, Collected Works, vol. 33, pp. 110-1l. Let us hasten to note that reformism of the right social-democratic strain is also a very real threat to revolutionary development, in Africa as elsewhere. See Sandbrook and Cohen, The Development of an African Working Class, London 1975.

40. Szentes, "The structure of society and its changes in the African countries", Studies on Developing Countries, no. 76/1975, p. 17.

41. Razvivayuschiesya strany: zakonomernosty, tendentsii, perpectivy, Moscow 1974. See the translation of the relevant section: AvakovMaidanik-Pokatayeva, op.cit., p. 152.

42. Ibid.

43. Stavenhagen, op.cit., pp. 58-9.

44. See Szentes, "The structure of society...", pp. 33-4.

45. See eg., Seidman, op. cit., pp. 16-17; Szentes, loc.cit., pp. 39.

46. Braginsky, "Early formation of the proletariat in tropical Africa", Africa in Soviet Studies, 1972 Annual, Moscow 1975, pp. 136.

47. Mbliniyi, op.cit., pp. 39, our emphasis.

48. Braginsky, loc.cit.

49. Otherwise, however, Elliot's method is a psychologizing behavioralism of the most idealistic strain. See Elliot, Pattern of Poverty in the Third World, New York 1975.

50. Ibid., pp. 100-3. For a different classification see Stavenhagen, op.cit., pp. 77-8. 
51. For a discussion of the methodology of "emic" categories (and their distinction re: "etic" concepts, see Harris, The Rise of Anthropological Theory, New York 1968.

52. In a sense, the strata of domestic servants and the like are eliminated from this consideration by default, although as Szentes ("The structure of society...", pp. 38) and Mbliniyi (op.cit., pp. 39) both point out, their significance from the standpoint of the urban proletariat is far from slight, though in a negative sense.

53. See Woddis, Africa, the Roots of Revolt, London 1960; Stavenhagen, op.cit.

54. Braginsky, op.cit., pp. 139.

55. See eg., "NEP: A policy of Transition to Socialism" problems of the Contemporary World 3/1974. Incidently the long-since discredited axiom of vulgar bourgeoise economics which sees the propensity to maximization as Basic Human Nature, and not as a moment of certain historical structures of social consciousness has been recently revived by Harold Schneider: Economic Man, New York 1974 .

56. Marx, Capital, vol. III, pp. 799. 
Mohamed Aden Sheck

Ahmed Mohamed Mohamoud "Ashur"

SOCIALIST ORIENTED DEVELOPMENT - THE SOMALI EXPERIENCE

The period we are living in is a time where the main contents is the transition from capitalism to socialism, a time of struggle between the two opposing social systems, a time of socialist revolutions and national liberation revolutions, a time of the break-down of imperialism and of the abolition of the colonial system, and a time of transition of more peoples to the socialist path. The progressive social development of mandkind is being built by the great forces of World Socialism, the international working class and the national liberation movements.

About eighty independent countries have emerged on the ruins of the imperial colonial system. Most of the people of the Third World have won their political independence and now face new and complicated tasks, which is to free themselves from economic dependence and abolish age-old backwardness.

These people want to be masters of all the riches and resources of their own countries and to attain a high cultural level using for this purpose all the achievements of modern science and technology. Which road of social development these countries have to choose is of great importance for the realisation of these tasks. The choice of the path of social development any one of these countries has embarked on is determined by the balance of class forces within the country and the degree of its economic dependence on imperialism. Some countries have taken the road of socialist development, others took the road of capitalist development, while in a number of countries the question still remains unsettled. Of substantial help in accomplishing this task is the rich experience of the Soviet Republics of Central Asia and the Mongolian Peoples Republic, all of whom have reached Socialism through the road of socialist development. Some experience in socialist oriented development has also been accumulated by the Somali Democratic Republic, and many other states in Asia and Africa.

The socialist oriented way of development is the way that permits countries that have shaken off the colonial yoke to carry out the transition to socialism, by-passing the capitalist stage of development or interrupting the process of capitalist development. The enemies of the socialist oriented development from the imperialist camp advocate that this way of development is unsuitable for the countries of Asia 
and Africa and that there is a little likehood of success along the road of socialism, since the main demands of a policy of socialist construction are not in keeping with present day African conditions. Among such reasons they list the difficult climatic conditions, the ossified structure of the African community, and the lack of skilled workers. The intention of the bourgeois ideologists is nothing other than to give unlimited freedom to private enterprise in the newly independent states, to allow imperialist monopolies to operate unimpeded and to let foreign and local capital strengthen their positions in these countries.

Some types of socialism of national variety are based on the idea that a scientific class analysis is not applicable for a number of African countries. This idea reflects in an unusual way certain phenomena present in the African reality of today.

Concepts of classless society in Africa can be explained by the widespread communal land ownership and land cultivation, the embryonic level of class stratification, the dominance of patriarchal, clan and tribal relations and obscurity of the class structure. Bourgeois ideologists have good reason to add weight to and consolidate these idea since they can be used to further their own class objectives.

The limitations of which certain indeologists of national versions of socialism fall prey stem mainly from the fact that they attach too much importance to special historical features and to present conditions, and rather than paying attention to the over-all patterns of modern stage of development they stress the almost mystical psycological "exclusiveness" which would make the African, Arab and countless others immune to general historical laws. Lenin wrote: "All nations will axrive to socialism-this is inevitable, but all will do so in not exactly the same way, each will contribute something of its own to some form of democracy, to some variety of the dictatorship of the proletarlat, to the varying rate of socialist transformations in the different aspects of social life"(V.I. LENIN, Collected Works, Vol, 23, pp.69-70). Lenin's thesis with regard to the diversity of paths for the transition of various nations to socialism does not rule out, but, on the contrary, confirms the existence of general historical laws.

Socialist-oriented development is a transitional historical stage, a stage of anti-imperialist, anti-capitalist and anti-feudal transformation. The basic contents of socialist oriented development consist of general democratic transformations. These include undermining the domination of imperialism in the given country, gradual nationalisation of big national capital; creation of a profitable state sector; 
anti-feudal and agrarian transformations with the participation and in the interests of the peasants; improving the condition of all working people through progressive labour legislation; development of education and health care; providing for broader influence of the masses on state policy; regulation, and in the future also limitation, of the development of middle and small national capital, and broad co-operation with socialist states and other world progressive forces.

We would like to present here a brief account of the history and geography of Somalia, the struggle of the Somali people against colonialism and for independence, the aftermath of independence and the experience accumulated in socialist-oriented development by the somali Democratic Republic during the revolution from 1969-1976, as well as the prospective plan of Somalia in building socialism.

\section{The geography of Somalia}

The Somali Democratic Republic is situated in the north-eastern part of the African continent forming the actual horn in the East of Africa. It extends from the gates of the Gulf of Aden on the North to Raskiyambooni along the coast of the Indian Ocean. It is bounded by Ethiopia on the West, Kenya on the South and French Somaliland to the Northwest. It has a coast line of 2,000 miles $(3200 \mathrm{Km})$, one of the longest on the African continent. It has an area of 262,600 square miles and population of 5 million approximately $99 \%$ of which are Muslims. It is a country of nomads par excellence and according to estimates $70 \%$ of the total population lead a pastoral way of life. Mogadiscio, with a population of nearly 400 thousand is the capital city and also the main sea port.

\section{History}

The history of Somalia is deep rooted and goes back to the remote past. Recent research (undertaken by varying institutions of African researchers and by individuals inspired to explore the colonial myths) reveals at present resourceful information about somalian past history.

The Somali ports of Mogadishu, Zaila, Merca and Brava are believed to have had contacts with the outside world when most other African countries were isolated. The most ancient of these contacts is evidenced by a series of pictures, inscription and drawings on the walls of Dayaralbaxi and Thabaid temples about an expedition undertaken by queen Hat Shepeut in 1,600 B.C. to visit the land of Punt (to the Egyptians ancient Somalia was the land of punt). The contacts between the two countries were not confined to trade only but were also centered on enriching cultural ties. 
To Greeks and Romans Somalia was known as Regio Aromatica.

The Somali coastal ports are known to have had contacts with the early Persians, Indians, the Chinese and Arabs.

The main articles of use which the ports offered for trade were ivory, gold, cinnammon, frankincense, myrrh and ostrich feathers.

Islam reached Somalia in its early inceptions and is evidenced by the construction of the Abdulaziz mosque in 1269 which to this day majestically stands firm. Somalia has witnessed the rise and fall of empires and states of these, the city-state of Mogadishu and the Awdal Empire were the most famous. The Awdal empire extended from the Northeastern region to Harar, Zaila being the capital city and sea port.

\section{The modern history of Somalia}

In their attempt to save the capitalist system's economy the Europeans aspired to find themselves holding grounds for exploitation.and dumping markets for their manufactured goods. By the 18th Century, many African and Asian countries felt under the throes of European colonialism. The European colonization process of destruction and pacification took the toll of the Somali people. The Somali colonial experience was and still is a painful experience.

The British, the French, the Italians and the Ethiopians were the main contenders in the Scramble for Somalia in the late 18 th Century. The British entered into treaties with the Somali people in the North in 1884-85-86, and yet again entered into treaties with Ethiopia in 1879 and 1889 in which the Western part of Somaliland was to be handed over to Ethiopia. The contents of this Anglo-Ethiopian treaty had been practically implemented in 1949 and 1955.

In 1898 the National hero Sayid Maxamed Abdulle Hassan mobilized the masses and declared an all-out war against occupation of the colonialists and in many occasions defeated the Invaders. By 1920 after the end of the lst World War, the British planes perhaps for the first time in the history of Africa, bombarded Sayid Mohamed's fort at Taleh.

In 1921, the Sayid died at Emey. However, the love of freedom did not die among the Somali people. Others took the task of liberating the mother land from colonial bondage.

After the defeat of the Italians in the 2nd World War ItalianSomali land fell under British military administration. On the 2lst of November 1949, the United Nations General Assembly, passed a resolution approving a ten-year UN trusteeship administration, nominating Italy as the administrative authority, under a UN advisory Council composed of 
the Philippines, Egypt and Colombia, to lead Somalia to the status of a sovereign state.

On April 1st 1950, Italy took over the administrative role to prepare the Somalis for independence. And on July 1960, the UN trust territory of Somalia, became independent.

The Northern territory, formerly the protectorate of British somaliland, following the armed struggle waged by the sayid, first, and secondly a political struggle carried out through the country ended the British rule over the country, and regained their independence in June 1960.

The two newly independent somali territories on the lst of July 1960 formed the Somali Republic.

\section{Aftermath of Independence 1960-1969}

In the liberation struggle all the diverse sections of given society participate in popular efforts towards the achievements of national independence but when that common goal is reached, inherent class antagonism inevitably arose amongst the social groups and classes due to their opposing interests. That is exactly what happened in Somalia soon after the country finally regained its national freedom and partial unification, in July 1960. During the period of struggle for independence, the political parties were strictly nationalist in their undertakings. Their main tasks was confined to the mobilization of the masses, and marking the colonialist as the enemy of the people. However the political parties did not educate the people politically and did not tap the national consciousness of the masses either. The national consciousness of the masses at the time of independence was embryonic and a crude caricature of what it should have been. Thus as soon as the colonial masters left, the leaders got set on a rat-race for the rule over the country. A struggle for power among the leaders erupted soon after the strugqle for independence had subsided. Each of them resorted to the backing of his tribe, and the tribe became their means to gain power. The political parties which once symbolised national struggle and claimed to represent and to serve the people, this time aspired to gain power through the tribe and the clan. The Government became the ruling political party and the political party became the Government, The ruling political party centralized the machinery of the Government, which deepened bureaucratic inefficiency. The civil servants undermined the economy of the state through corruption, black-marketing and the political leaders worked on get-rich-quick schemes. The political parties had no plamned economic programmes during the struggle for 
independence, and neither had they forged new developmental programmes to set the new state on a firm ground. The leaders had their hearts set on carbon-copying the colonial economic structure and eagerly sought foreiqn aid.

The political leaders proved themselves no better than the colonial Furopeans in securing for themselves prestige rights and privileges. The freedom for the sake of which so great a price had been paid by the people, the high hopes placed upon national independence were hopelessly dashed to the around. The basic civil rights of the individual were deliberately suporessed and replaced by naked tribalism, nepotism, open theft of public funds by those entrusted with the affairs of the state.

We could sumarise the social evils that endangered national independence as follows:

(1) Lack of national conciousness;

(2) Lack of national economic planning and development;

(3) Tribalization of political organization and centralization of power;

(4) Instituting nepotism, favourism and regionalism;

(5) Corruntion, fraud, tax-evasion;

(6) Fostering neo-colonial and imperialist values relating to the economy and the socio-political structure.

In the end these social evils threatened the very existence of the Somali people as an independent sovereign state, and the birth of a revolution was a qlaring necessity. The Revolution was born on 21 st october 1969, after the armed forces overthrew the rule of the corrupted regime.

\section{Birth of the revolution}

Social revolutions do not grow overnight as mushrooms, but they take place when specific social conditions become ripe with in the structure of a given society, or the motive forces behind them reached the culmination point. The causes of the October 1966 Revolution were the utter neglect by the leaders of the old corrupt regime of the elementary rights of the Somali people. On the 2lst of October 1969 the Somali armed forces interpreting the general feelings and sentiments of the masses, led by progressive officers had over-thrown the corrupt ruling regime and staged a bloodless revolution.

The over-throw of the corrupt regime made the birth of the revolution come true. The fact that the armed forces took the role of leadership was made possible by their endowment with powers which other sectors and institutions of the society lacked such as: 
(1) The armed forces as part and parcel of the Somali people were numerically the strongest govermment institution

(2) Among the members each and every region or district is represented

(3) It was the only mighty force created and structured for the defence and welfare of the Somali people internally and externally

(4) It was the only force discreetly organised

(5) It was the only force conferred upon with the power of the arms

(6) It was most disciplined and organisationally systematized

(7) It was a force whose leaders were nationally and progressively oriented

The revolution put into motion a new dynamic progressive system based on truly revolutionary forward-looking policies. One of the first moves taken by the newly formed revolutionary government was the complete abolition of the constituted organs existing at the time such as the national assembly, council of ministers, supreme court etc, and their replacement by new organs founded on the principle and spirit of the October revolution. The revolutionary state was named the "Somali Democratic Republic".

The legislative and executive process of the states were vested in the Supreme Revolutionary Council presided by an elected Chairman who also exercises the function of head of state. Meanwile technical government was appointed comprised of secretaries of state to the routine government administration and assistance in the initiation of laws as well as the formation of a government policy. The basic principles and objectives of the Revolution constituting the general guidelines for the state were clearly spelt out in an official document entitled "The First Charter of the Revolution".

The declaration of policy embodied in the first charter of the Revolution clearly set forth the principles by which the revolutionary government would guide Somalia in the future. These principles are described below.

\section{Internal policy}

(1) To constitute a society based on the right of work and on tne principles of social justice

(2) To prepare and orient the development of economic, social and cultural progress of the country

(3) Liquidation of illiteracy and the development of an enlightened patrimonial and cultural heritage of the Somali people

(4) The basic development of the writing of the Somali language

(5) Liquidation of all kinds of corruption, all forms of anarchy, the 
malicious system of tribalism in every form and every other phenomena in bad practices in state activities

(6) To abolish all political parties

(7) To conduct at appropriate time free elections

\section{External policy}

(1) Support for international solidarity and national liberation movements

(2) Oppose and fight all forms of colonialism and neo-colonialism

(3) Struggle to maintain the Somali national unity

(4) Recognize strongly the principle of peaceful co-existence between

all peoples

(5) Continue and preserve the policy of positive neutrality

(6) Respect and recognize all legal international commitments undertaken by the Somali Republic.

One of the major tasks of the Revolution, was the political education and re-organisation of the masses as well as their mobilization for the transformation of the country. This act served as a means of waging the struggle for liberation from the bonds of neo-colonialism, and yet at the same provided proof that the masses were capable of doing things themselves and in the process reincarnated the shattered self-confidence of the masses to the extent that doing things themselves became a condition of genuine freedom, autonomy, independence. It was thus aimed at strengthening national self-reliance.

The people had been involved in the revolutionary process, making them a force capable of influencing it, of controlling it. For that purpose a political office which had been called in the first place as the public relation office had been established. The office has various sections to deal with different social organisations such as: youth section, workers section, women's section, militia section, mass media section, regional \& districts affairs section and international relations section.

The office has its representatives in the regions and districts of the same organisation. The main task of the political office is to mobilize the people for the transformation of the country to give them political education.

By the end of 1970 the Halane Camp had been instituted, where all state officials, students, graduates engaged in the public administration (teachers, doctors, etc) had to attend for three months courses for political education, for professional updating and revision, and for ideological formation. 
Voluntary labour Iska Wah u Oabso (a work of collective interest) had been introduced throughout the country. In practice, the state takes a hand by financing or supplying the materials for a certain percentage of the budqeted expenses (generally not more than 50 percent), and the actual performance of the project is entrusted to the voluntary work of the population. Self-discipline, self-management and community responsibility are encouraged, while at the same time the feeling of social ownership, direct paxticipation in the development of the national. economy, the values of collectivism are all developed. In this way towns and villages have arisen in the countryside, and the first mobile hospital units, the first schools, the first wells, the canals, roads and airports have been built, shanty towns have disappeared and their inhabitants have been transferred to the new quarters built by themselves. As Iska Wah $u$ Oabso is a voluntary community work which gathers together the forces of given area for collective development, it also has the function of combatting tribalism and strengthening the national conscience. Different aspects of these initiatives and of the policy of mobilization and of alliances, their objective from the very begining has been both social and economic, together.

Crash programmes were started for specific purposes, confirming the choice of development strategy that have been illustrated. They came about in order to increase the production of food-stuffs and gradually to eliminate the importation of cereals, bringing the uncultivated land into cultivation. They vere also introduced to help to settle the population in agricultural areas, likely to produce an income permitting the standara of life to be raised and to absorb unemployed young people into aqricultural in order to develop their sense of solidarity and love of work.

State farms were organized with the recruitment of young unemployed persons, of refugees from the occupied somali territories, of individuals to be re-educated, or of small-scale peasants at starvation level and of herders convinced to share in this settlement experience.

on the 7th of May 1970 nationalisation measures have been taken which included foreign banks, SNAI (Giohar sugar refinary), the ItaloSomali electricity company, the oil distribution and operating companies and the insurance companies. This gave the possibility to establish a profitable government sector of the state economy, as President siad stated when he announced the measures, it took over the management of the decision-making organs in the economic sector, in order to guide available resources towards the achieving of objectives able to meet the demands and the immediate needs of the great masses of the people. The effect of the nationalization measures were soon to make themselves felt. 
Somali adopts scientific socialism

The second charter of the Revolution issued on 1st January 1971 declares in parts:

"... As the first charter of the Revolution lays down that the basic aim of the state is to constitute a society based on labour and the principle of social justice; and that, since it is considered that socialism is the only philosophical system that will help establish such a society; the Somali Democratic Republic shall take all necessary stens for its full implementation for the progress and prosperity of the Somali people..."

The adoption of scientific socialism by Somalia was the logical out-come of the october 1969 Revolution, which, as we have indicated earlier, heralded a new era of social reconstruction in the country. Fxolaining more to the masses the adoption of socialism by Somalia as its ideoloqical basis the president of the supreme Revolutionary Council Jaalle Mohamed Siad Barre said:

"Our socialism cannot be called Somali socialism, African socialism or Islamic socialism. It is the original scientific socialism which emanates from the true noble products of human though and sum-total of the experiences of man. Our socialism is independent and is governed by its own specific conditions to set up a society based on equality and social justice as laid down by the general principles of scientific socialism. Our socialism does not oppose our good and positive habits, great traditions and Islamic Religion".

Extensive explanatory campaigns of scientific socialism have been launched throughout the country, seminars have been organised for government officials, workers, peasants and in the army units to study scientific socialism, orientation centres as well have been built in the districts and regions for the orientation of the masses.

After the announcement of 2 lst October 1970, the state organizations immediately concerned the social and economic relations which it intended to install. For example, administrative reform, regional decentralization, regional governments and district, village and town area committees, have been formed in response to the precise design of an economic development alternative to the neo-colonial logic, or otherwise to be instruments of revolutionary democracy engaged in organizing the participation of the people in this development and these social transformations. In foreign relations, with the advent of the revolution, the declaration of new foreign and internal policies and the adoption of socialism as a way of life, all contributed to herald a new outlook to our relations with the outside world, thus bidding 
fare-well to a period of stagnation and national frustration. The main issues regarding the reshaping of the national image in the field of foreign relations were summarized in the first charter.

Within the first few years of the Revolution, the active and sincere implementation of these principles were capable to take somalia out of the political and diplomatic isolation which the nation endured for nearly nine years. It was followed by a period of relentless efforts which proved capable to redress the appalling situation and restore the nation's respect and dignity.

As a result, the Somali relations with the African countries, Arab World, the Muslim World, the socialist World, the non-aligned World, the liberation movements and the peace-loving peoples of the world at large were considerably consolidated and cemented.

In the educational field revolution meant the formulation of policies consonant with the history and culture, and taking into account the modern conditions of development. The objectives and philosophy of education under the revolution was:

(1) Democratisation of the educational process

(2) Disengagement from colonial education

(3) The literacy campaign

(4) Youth mobilization

(5) Prioxity in introducing technical schools

(6) Establishment of a national university

The number of students attending schools in the academic year 1969-70 was the pitiful figure of 42, 156; six years later in the academic year 1975-76 the enrollment soared to a record of 249,580 students. This spectacular progress was not confined to formal schools, but long strides have been made in the field pre-primary education, adult and women education.

Basic changes had been reflected in the enrollment policy, curriculum activities, teacher training, text-books, medium of instruction as a process of disengagement from the colonial system of education. A national literacy campaign which aimed to lay a solid base for literate population and initiate a programme of skill training and citizenship education was opened in March 1973.

It was found necessary to reconstruct most of the existing school building as well as building new ones to meet the demand brought on by the rapid growth of the school enrollment; and for the purpose through self-help schemes 2010 classrooms were built in the country.

One of the most revolutionary steps taken during the revolution was 
the introduction of a script for the Somali language, as the official language of the state on 21 st october 1972 and its replacement of the various existing foreign languages with the introduction of the written Somali language in the public administration.

Along with idea of self-reliance, instead of depending upon foreign scholarships for the training of the Somali students a full-fledged national University with faculties of agriculture, medicine, veterinary, education, economics, chemistry, engineering, geology and law is being established.

With regard to health, before the revolution, the health services were scarce and centralized in the capital, absolutely neglecting the regions and districts, especially as regards of specialized services.

Immediately after the advent of the revolution, qualified members i.e. "sanitary personnel" for the treatment of sick and preventive campaigns were distributed justly in every region and in the districts.

The decisive factor in this had been self-assistance (Iska wah u Qabso), by which, in 1970-1974, 200 health centres, 150 infirmaries, 30 hospital wards had been created.

The 1971-1973 three-year development plan had been passed as a realistic plan, with targets within feasible limits, based on financial rehabilitation and the redimensioning of foreign aid and the orientation of economic and social development according to socialist criteria.

Priorities were given to productive choices, the up-grading of the public sector and the subordination of the private sector to programming as well as the growth of co-operatives.

In the agricultural sector the formation of 419 co-operatives in the dry-farming areas and 69 in the irrigated areas, had been envisaged.

8385 families of peasant farmers were to benefit from them, and were to be given assistance from a service for land development, aimed at supplying technical input assistance and the instruction necessary to manage the farms.

State farms had been formed, $393 \mathrm{kilometers} \mathrm{of} \mathrm{canals} \mathrm{opened,}$ 10,000 hectares of 1 and were grown with new crops, the production was diversified and a radical change in the countryside instituted both in the sense of extending the areas cultivated, and of cultivating them to withdraw them from their dependence on single-cropping.

The industrial sector became conceived in complementary terms to agriculture and animal husbandry giving priority to the internal demands. 


\section{Rural development campaign}

In 1974-1975 a rural development campaign had been launched in the Somali Democratic Republic with fundamental objectives such as:

The elimination of illiteracy, the prevention and cure of diseases, the improvement in livestock health facilities, the raising of the political consciousness of the masses, the taking of the census of the people and livestock, the creation of a society steeped in justice, equality and planning of developments based on the principles of socialism.

The objective of the campaign has been to bring about change, from top to bottom, which directly touches the livelihood of the nomadic population so that concrete improvements can be made, specially in the elimination of the anti thesis between town and the country side.

The people who participated in the campaign numbered no less than 125,000 persons falling into various categories.

$1.257,779$ persons learned how to write and read, 11.048,176 of the livestock population received medical treatment and $2.313,670$ received vaccinations.

The people who received medical treatment were $1.614,261$ persons and those who received vaccination against various diseases were $14.187,98$.

As a consequence of lack of rain in Somalia during 1969-1975 (except for 1972) the country had been hit by a serious drought in the 1974-75 years. The country had lost at least a third of its sheep and goats, more than a quarter of its cattle and a tenth of its camels.

The disaster went beyond the death of human life and livestock, immense areas of northern and north-eastern somalia nearly turned into a desert.

The revolutionary government prepared and equipped many relief camps and by 1975 the number of people in the relief centers reached at least 750,000 nomads. As already mentioned one of the main objectives and priority issues in the strategy of the country's development planning is the settlement of nomad population and an opportunity presented itself with the recent severe drought of 1974-75 which seriously disrupted the economic and social livelihood of the larger part of the nomadic population.

The preliminary steps taken in the direction of resettlement of the effected nomadic population was the surveying of possible and suitable resettlement areas for the affected nomadic population. 
The destitute population in the relief camps in the 8 affected regions were given the choice of deciding their future occupations between agriculture, fishing, livestock rearing and others.

By mid August, 1975 a total population of 120,000 was transferred from their nomadic habitat to be settled in 6 agricultural and fishery areas.

The resettlement effort was not easy at all and demanded the effective mobilization of both the human and financial resources of the country, as well as external assistance.

About 5.000 persons participated in the transfer and resettlement exercise including government civil servants, the armed forces, university students and members of the public. Many friendly countries and international organisations assisted the somali people in the campaign, especially the Soviet Union, which participated by sending air and land transport.

The objectives behind the resettlement programmes include:

(1) The overall restructuring of the national economy aimed at the full utilisation of both the human and material resources of the country. (2) The establishment of model communities for the future settlement of the remaining nomadic population.

(3) The establishment of local points for the building of a socialist society based on social justice and labour and free from the exploitation of man by man.

A resettlement development agency has been created, headed by a general manager, assisted by a number of dixectors. The main tasks of the agency include:

(1) Implementation of an economic and social policy in the field of human resettlement, aiming at the self-sufficiency of the resettled communities in agricultural and fishery areas on the basis of social transformation of the society.

(2) Participation in the overall economic development of the country such as increasing food production.

(3) Function as the vehicle for future resettlement of nomadic populations after the experience obtained from the present resettlement programmes.

In the resettlement areas, the agency is represented by revolutionary committees consisting of a chairman nominated by the president of the supreme revolutionary council on the advice of the higher committee for resettlement and development, the heads of government organs carrying out activities at the resettlement areas and the chairman of the 
various popular committees of the resettled communities themselves. The results of the resettlement became very successful especially in the psychological adoption of the population which have been settled.

The strategy and policy of the revolutionary government is to constitute a society based on the right of work and in the principles of social justice and in order to develop the country economically, socially and culturally. For the realisation of the above mentioned statement, on the 7th of March 1974 the Somali Revolutionary Council and the Council of secretaries of state approved a development programme of five years 1974-1978, based on the following principles:

(1) Maximising resource utilisation in the production of both commodities and services and ensuring continued growth;

(2) Creating conditions where the national products is distributed equitably among the people;

(3) Decentralising socio-political administration of the country in the regions and districts to enable socio-economic development in the country to take place in regional balanced growth;

(4) Organising economic activities on a basis where the means of production are owned and operated by and in the interest of society as a whole and also through that process involve as many people as possible in decisions regarding investment, production, employment and income distribution.

(5) Mobilising and utilising internal resources including the labour force to the maximum. Revolutionary orientation and self-help activities will therefore be the major instruments for speeding up socio-economic development of the country on external assistance in development efforts in as short a time as possible;

(6) Creating co-operatives in line with the socio-economic requirements and political philosophy of the country. Co-operative societies will be established in agriculture, livestock fisheries and other productive service sectors of the economy.

The Somali people due to the tasks accomplished in the mass mobilisation and political education during the last six years of the revolution have reached a level of political consciousness and revived nationalism, a level of constructive activity and confidence which the nation can all be proud of.

Therefore the Supreme Revolutionary Council, for further democratisation of the Revolutionary system and by acting in accordance to the principles of the first Charter, have decided to form a political party in order to take over the leadership of the society and the state and which has to consist of the most advanced, conscious representatives 
of the working people and other progressive forces of the society. The President of the revolutionary council, Jaalle Siyaad, said at the sixth Anniversary of the Revolution on this accord: "We have decided to form a polttical party. Such a task is not simple. It needs careful study and strict preparation on all levels". The task of preparation was immediately embarked upon after the announcement was made. It is now at a satisfactory level which will enable the revolutionary government, in the near future, to form an instituted party.

The remarkable achievement by Somalia, under the Revolutionary Government is chiefly due to the timely adoption of the principles of scientific socialism, fully supported by the general public, politically conscious and ready to fight against the forces of local as well as international reaction, in order to safeguard popular interests of the Somali masses and World progressive forces. 
Iars Rudebeck

CONDITIONS OF DEVELOPMENT AND ACTUAL DEVELOPMENT STRATEGY

IN GUINEA-BISSAU

Twenty years ago, in September 1956, Amilcar Cabral and a small group of comrades founded the Partido Africano de Independencia da Guine a Cabo Verde (PAIGC) in Bissau, then the capital of a small and backward West African colony named Portuguese Guinea. Seventeen years later, the first elected National Assembly of the People met in Boe in the eastern part of the country, to proclaim the de jure existence of the sovereign state of Gulnea-Bissau. Through political and military struggle, the PAIGC had then freed about two-thirds of Guinean territory from the Portuguese colonial system. One year later, in september of 1974, after the fall of the fascist regimes in Lisbon, even Portugal herself formally recognized the Republic of Guinea-Bissau. More than five hundred years of direct colonialism in west Africa had finally come to an end.

At present the PAIGC controls the state of Guinea-Bissau and directs the development of the country. The PAIGC is in power also in the sister Republic of Cape Verde, but my discussion here will be limited to conditions and events in mainland Guinea. The intention is to make use of the concrete experience of Guinea-Bissau in order to highlight some of the possibilities and difficulties of what we may call non-capitalist or socialist oriented development in the third world. This is only a brief and preliminary report, prepared in order to evoke constructive criticism. It is based upon knowledge and information gained during two and a half months of research work in Guinea-Bissau in early 1976. This work is a continuation of my earlier studies of the new society under construction in the liberated areas of Guinea-Bissau, while the armed struggle against the Portuguese colonial army was still going on, which I have reported upon in my book Guinea-Bissau. A study of political mobilization (Uppsala, The Scandinavian Institute of African Studies, 1974).

We shall begin by looking at the internal and external conditions under which the PAIGC and the government of Guinea-Bissau are at present leading the struggle against underdevelopment in their country. Special attention will also be given to the social basis of state power and the role of political mobilization. In a following section I shall then try to characterize the concrete development strategy that has 
emerged during the long years of armed struggle and the short period of complete independence. I shall conclude with a few brief remarks on what we may be able to learn, in a more general and theoretical sense, from studying given conditions and actual political practice in this way.

\section{Internal and external conditions of development}

In order to enable us to study the interaction of internal and external conditions of development it will be useful to list them separately, although naturally they are not strictly separate in reality.

The following conditions are mainly internal in character:

(1) Guinea-Bissau is an agricultural country at a low level of economic development, with hardly any industry and very poor infrastructure. The main source of wealth, both now and in the foreseeable future, is agriculture. There is also some mineral wealth, mainly bauxite.

(2) When the Portuguese colonial power withdrew in 1974, it left the country's treasury almost empty. There is now a serious problem of lacking financial resources, creating dependence upon foreign aid and credits, which cannot be made up for through foreign trade, as the balance of foreign trade is very negative. This is of course a clear example of a condition of development which is, at the same time, both internal and external.

(3) The country is small and fairly densely populated for west African conditions: about 800.000 inhabitants on a territory of 36,125 square kilometers.

(4) There is no particular ethnic group heavily dominating all others, but rather a kind of balance between four main groups and several smaller ones.

(5) The number of white settlers was always very small, and the few who remain in independent Guinea-Bissau do not pose any serious political problem.

(6) The main political strength of the PAIGC is in the countryside, especially in the two-thirds of the country that had been liberated from colonialism before the surrender of the Portuguese and where a new society has already been under construction for a long time.

(7) Among the urban population, on the other hand, the attitudes and ideals of the dominant petty bourgeois groups are not always consistent with the developmental goals of the party and the government.

(8) The general educational level of the people, inherited from colonial times, is very low. 
The following conditions are mainly external in character:

(1) It is a historical fact of great importance for the country that a long war of national liberation was imposed upon it by the Portuguese colonial power.

(2) The economlc importance of Guinea-Bissau to the international capitalist system is insignificant. There is, however, no direct relation between this fact and the political importance of Guinea-Bissau as an example of independent and progressive development in Africa.

(3) This is related to Guinea-Bissau's role in African politics as a consistent member of the strongly anti-imperialist group within the organization of African Unity (DAU).

(4) The great dependence of Guinea-Bissau on foreign aid and credits has already been mentioned in connection with the lack of internal financial resources. No more than one-third of the cost of imports during the first seven months of 1975 were covered by export earnings. ${ }^{1}$ Swedish annual aid alone, about 9 million dollars a year 1976-79, is twice as great as export earnings during the first seven months of 1975 (4.4 million dollars). The most important points in the network of international relations upon which Guinea-Bissau depends in order to make up for the deficit are (in alphabetical order) Algeria, Cuba, The Soviet Union, Sweden, and the UN. But a number of other organizations and countries, both capitalist and socialist industrialized and third world countries, are involved as well. Portugal, naturally, also has a special and important role in relation to Guinea-Bissau, not least as the almost exclusive foreign trade partner so far.

(5) Dating back to the years of armed struggle, Guinea-Bissau cooperates militarily with the Soviet Union, while maintaining a policy of non-alignment with regard to the military blocs of the great powers.

(6) Guinea-Bissau was paid an official state visit by President Agostinho Neto of the People's Republic of Angola in March, 1976. In connection with this visit, Presidents Luis Cabral, Agostinho Neto, and Sekou Touré of Guinea-Bissau, Angola, and Guinea-Conakry, respectively, and Prime Minister Fidel Castro, Cuba, met In Conakry in order to discuss common problems of the antiimperialist struggle. Participation in this meeting is another clear indication of Guinea-Bissau's stand in international politics. ${ }^{2}$

(7) Guinea-Bissau's immediate geographical neighbors are Senegal and Guinea-Conakry, two countries that are politically and economically opposed to each other. Although Guinea-Bissau's political relations with Guinea-Conakry, dating back to the years of armed struggle, are much more intimate than with Senegal, good neighborly relations are still maintained in both directions. 
The conditions now listed dominate the total situation in which the development policies of Guinea-Bissau are implemented. This situation may be summarized as that of a small and economically underdeveloped agricultural country with lacking financial resources, but with a strong and ideologically radical political organization with firm support in the countryside, built up during eleven years of successful armed struggle for national liberation. The main foreign policy principle is nonalignment, but for historical reasons, Guinea-Bussau has developed closer ties of cooperation with the industrialized socialist countries and the strongly anti-imperialist third world countries than with capitalist countries in general. This, however, by no means excludes close ties of economic and political cooperation with some of the smaller capitalist countries, in particular Sweden, whose governmental cooperation with the PAIGC dates back to 1969. There is growing cooperation with the rest of the capitalist world as well. Guinea-Bissau is, for instance, an associate member of the European Economic Community through the Lome Convention, and plans are being made for extended cooperation with Brazil.

Foreign dependence counterbalanced

The negative balance of foreign trade and the consequent lack of financial resources was 1 isted above both as an internal and as an external condition of development. What does Guinea-Bissau have to mobilize as a counterbalance to the dependence upon forelgn ald and loans created by this situation?

Table 1. Guinea-Bissau's exports and imports during the first seven months of 1975. Approximate value in U.S. dollars.3

\begin{tabular}{ll}
\hline Exports & Imports \\
\hline $4,446,000$ & $13,914,000$ \\
\hline
\end{tabular}

Table 2. Coverage of imports by export earnings, in percentages, during the first seven months of 1975.4

\begin{tabular}{lcc}
\hline & Monthly 8 & Accululated 8 \\
\hline January & 10.4 & 10.4 \\
February & 5.3 & 7.3 \\
March & 53.8 & 22.3 \\
April & 11.7 & 19.0 \\
May & 44.5 & 24.0 \\
June & 62.3 & 29.3 \\
July & 57.5 & 32.0 \\
\hline
\end{tabular}


Table 3. Portugal's share in Guinea-Bissau's foreign trade ("principal goods"I during the first seven months of 1975, in percentages.5

\begin{tabular}{ll}
\hline 8 exports & imports \\
\hline 73.7 & 55.6 \\
\hline
\end{tabular}

Table 4. Balance of foreign trade with Portugal and the only three countries with which Guinea-Bissau had a positive balance during the first seven months of 1975. Approximate value in U.S. dollars. ${ }^{6}$

\begin{tabular}{lrr} 
Portugal & $-4,200,000$ \\
Algeria & + & 295,000 \\
Cape Verde & + & 411,000 \\
S. Tomé e Principe & + & 357 \\
\hline
\end{tabular}

Although this is not the place for a detailed analysis of the foreign trade figures, it should be mentioned too that 23 percent of the imports during the first six months of 1975 consisted of rice, whereas 82 percent of the exports were of vegetal origin. More specifically, 75 percent of the exports were groundnuts exported exclusively to Portugal, 87 percent of which were shelled in Guinea-Bissau. The second largest export product was lumber, which accounted for 9 percent. Algeria was the main importer of this. The third largest export product was refined cane sugar, accounting for 6 percent, all of which went to Cape verde. 7

The question was raised as to what Guinea-Bissau has to mobilize in order to counterbalance this extreme situation.

The counterbalance is to be found (1) in increasing production and (2) in the strong political organization of the country. The two go together, even very closely, as we shall see, for instance, in the next section of this paper when dealing with the developmental goal of increased rice production.

According to the ideology of the PAIGC, the people must be brought to see for themselves the connection between the goals of material and social improvement and the means that are necessary in order to reach them. It is in the very formulation of goals in close connection with the experiences of people and the possibilities of reality, and in the simultaneous realization of what obstacles must be removed in order to make possible the attainment of those goals, that we find the focal point of the political mobilization process. The following of ten-quoted passage from the PAIGC guidelines, written by Amilcar Cabral at the beginning of the struggle, illustrates how clearly and simply the basic 
problem of political mobilization has always been posed within the PAIGC:

\begin{abstract}
"Always remember that the people do not fight for ideas, for things that exist only in the heads of individuals. The people fight and they accept the necessary sacrifices. But they do it in order to gain material advantages, to live in peace and to improve their lives, to experience progress, and to be able to guarantee a future for their children. National liberation, the struggle against colonialism, working for peace and progress, independance -- all these will be empty words without significance for the people, unless they are translated into real improvements of the conditions of life. It is useless to liberate a region if the people of that region are then left without the elementary necessities of life."8
\end{abstract}

It is a most reasonable thought that development of society and political mobilization in this concrete form condition each other mutually in all societal situations where development cannot be expected to occur spontaneously, but must instead be seen as an effect, vitally necessary but difficult to attain, of conscious efforts to overcome all obstacles raised by the intertwined structures of the international and national, political, economic, and social systems. And it is precisely in such a situation that Guinea-Bissau, like so many other countries of the third world, finds itself.

Guinea-Bissau offered a concrete example of how internal political strength may be used to counterbalance foreign dependence in early 1976. On February $28 \mathrm{th}$, the government of Guinea-Bissau announced the complete nationalization of the Portuguese Banco Nacional Ultramarino, as far as its operations in Guinea were concerned. This bank had up to then been in charge of issuing the Portuguese/Guinean escudo in circulation in Guinea-Bissau. But now the National Bank of Guinea-Bissau was given the task of issuing a new national currency, the peso, non-convertible but at par with the Portuguese escudo. This step was taken, after negotiations with the Portuguese government had come to a complete impasse with regard, in particular, to the question of the public debt of the former colony of "Portuguese" Guinea, which the Portuguese government wanted the government of independent Guinea-Bissau to inherit. This was completely unacceptable to the Guineans, and the best solution appeared to be a clean break with the Portuguese currency system, giving GuineaBissau complete control of her foreign exchange operations. The Portuguese government retaliated harshly by freezing all Guinean assets in Portuguese banks, but Guinea-Bissau stood firm, and in June of 1976 there were clear signs that the problem would soon be resolved to the satisfaction of the Guinean side. ${ }^{9}$

The organization and basis of state power

The local committee (comite de basel is where the people of GuineaBissau are brought most directly into daily contact with the organized political structure of their country. This is a popularly elected five- 
member committee that the PAIGC attempts to establish in all villages and urban neigborhoods. At least two of the five members have to be women, according to party rules. At the moment of total liberation, the local committees already existed almost everywhere in the liberated areas. They have since been gradually extended to cover the entire country, including the bairros (urban neighborhoodsl of Bissau, where close to 80,000 people live. No official figure on the number of base committees has been published. My own very approximate estimate is that there are perhaps between 1,000 and 1,500 such committees spread all over the country. In the rural areas there may be on an average perhaps 500 inhabitants, including children, per committee, often even less, sometimes considerably more.

The local committees are grouped in sections with about 5-10 committees per section. A political commissar (responsavel de seção) is in charge of each section. A number of sections then go to make up a sector, of which there are 37 in the entire country. The largest administrative and political division below the national level is the region, of which there are eight: Bissau (4 sectors), Cachau (6), Dio (5), Bafatá (6), Gabu (5), Tombali (4), Buba (4), and Bolama (3). The only elected element in this political and administrative structure is the local committee. The political commissar at the level of the section as well as the members of the sector and regional committees, are appointed, the president of the regional committee being at the same time both administrative governor and head of the regional party organization. In order to assist him (her) in this latter function, a post as regional secretary of the party was created and gradually introduced in $1975-76$.

Besides the structure now described, there is also the National Assembly of the People, elected for the first time in 1972, in the 1iberated areas of the country. It has since held three sessions, the last one in April and May of 1976, and the first one in 1973, when the state of Guinea-Bissau was proclaimed de jure on september 24 th. A new assembly is about to be elected, as the regular term is for three years.

The National Assembly is an important organ where announcements are made, debates carried on, and laws are passed. But it is in the politico-administrative structure beginning with the base committee and ending with the national government that a permanent working contact is maintained between the national leadership and each one of the rural villages where the people live. This state structure developed and took form in the liberated areas during the years of the struggle. It is therefore not a mere extension and adaptation of the colonial state, as we find in so many other African countries. It represents, on the cont- 
rary, a radical break with the colonial state, whose place it has taken in order to pave the way for a new system.

The social basis of state power in Guinea-Bissau is thus the peasantry, politically mobilized and organized by the PAIGC during the liberation struggle. The working class of Guinea is numerically very small, and has not presented any political problems to the regime so far. It, too, is part of the social support of the regime. The urban petty bourgeoisie, on the other hand, does not offer any broad, spontaneous support of PAIGC policies, which tend to favor the countryside as opposed to the urban areas. A clear indication of this problematic political situation is found in the frequent calls for activation and vitalization of party activities in Bissau. 10

The class character of the party and the regime shows also in the recruitment of political cadres and leadexs. Amilcar Cabral himself was of petty bourgeois social origin, as most of the other original leaders of the national liberation movement, including, of course, Luis Cabral, President of Guinea-Bissau and younger brother of the murdered founder of the PAIGC. But these few men could never have made a revolution alone, and the bulk of people with political responsibilities, at least below the top level, are peasants and sons and daughters of peasants who have received their training in practical political work and in the schools of the party. The first of these was the cadre school set up in Conakry as early as in 1960, followed later by the many various schools of the liberated areas and by training abroad.

In addition to the PAIGC cadres, the government of independent Guinea-Bissau also makes use of a number of civil servants and lower administrative cadres who served earlier in the colonial state apparatus. Serious efforts are made to restrict such cadres to technical functions.

As educational requirements rise and the administration expands, a division even within the category of PAIGC cadres is beginning to be discernible between what we might superficially call technocrats and ideologists. At this early stage, however, we can only speculate about the possible implications of this.

\section{The concrete development strategy of Guinea-Blssau}

The best indicator of the class character of a regime is probably what it actually does, in political and economic practice. In the case of Guinea-Bissau, this means the concrete policies, within various fields, which together make up the development strategy of the country. These policies will now be briefly characterized, field by field. 
Agriculture. The most acute developmental problem in Guinea-Bissau at present is self-sufficiency with regard to food. The staple food of the people of Guinea is rice. But during the war, production gradually decreased on the Portuguese side, until the colonial regime was forced to import large quantities during the final years. The first developmental goal is therefore to reach the pre-war level of production for the whole country, which is 120,000 tons of raw rice per year. This would cover internal consumption (estimated to be about 60,000 tons of husked rice, equivalent to about 90,000 tons of raw rice), and it would also give a certain surplus to be exported. The Guinean authorities hope this goal will be reached as soon as in $1977, i . e$. when the rice planted during the summer of 1976 has been harvested. As an important illustration to what was said earlier about the connection between production and politics, a great deal of political work all over the country was directed at mobilizing the peasants to carry out the work necessary to achieve the desired production of rice. It is particularly important to construct a great number of dikes, to keep the salty water of the tide away from the flat coastal lands of Guinea, thus making it possible to expand greatly the acreage devoted to the cultivation of rice. This was a constant theme of discussion at the political meetings of many Guinean villages during the winter and spring of 1976.

Table 5 shows the imports of rice into Guinea-Bissau since 1974. Note that 1975 was the first full year of complete PAIGC control of the country.

Table 5. Imports of husked rice into Guinea-Bissau, in tons. ${ }^{11}$

Tons of imported rice

$1974 \quad 30,000$

$1975 \quad 20,000$

1976 (foreseen) 10,000

1977

Considering, that as mentioned above, no more than one-third of the cost of imports was covered by export earnings during the first seven months of 1975 and that over one-fifth of the value of imports consisted of rice, it is easy to realize what a great relief it will be to the national economy when this first goal of economic development is reached. On1y when the dependence on loans and gifts for the basic support of the people has been eliminated, will it really be possible to speak of autonomous development in the interest of the masses of the people. 
The primary goal of self-sufficiency in food is obviously basic in a country where close to ninety percent of the economically active population are peasants. Besides,by promoting this goal politically and technically, through agricultural technicians and party cadres working hand in hand at the levels of the villages and sections, the PAIGC government also uses such measures as raising the relative prices paid to the peasants for their products.

During the last years of the colonial regime, the peasants received a little over 25 percent (2.5 escudos) of the price paid by the consumer for the most common variety of husked rice. During the harvesting seasons of 1975 and 1976, they received a little over 40 percent (5 pesos) of a price which had been raised from about 9 to 12 pesos. ${ }^{12}$ It is of course important, too, that a great deal of the difference now goes to the state-run People's stores organization (see below) rather than to private traders. This is a good example of how the government tries to favor the people of the countryside in relation to the urban population. Another example is the fact that the population of the former liberated areas are exempted during a period of three years, from paying the special national reconstruction tax introduced in 1975.

Agricultural land in Guinea-Bissau is communally held by the people of the villages, although in a juridical sense it is the property of the nation, according to a law of nationalization passed by the National Assembly in 1975.13 It is normally cultivated family-wise, with privately owned tools. The long term goal of the PAIGC is to transform this system of land-holding and cultivation into a modern cooperative system in which all land is held and cultivated by producers' cooperatives. The idea is to move slowly, step by step, not forcing the peasant to adopt measures they do not accept or understand. The first step will normally be a buying cooperative, where a number of peasants pool their resources in order to buy seeds, fartilizer, perhaps a tractor or some other machine. When this leads to increases in production, the time may come to start a sales cooperative. When the profit from the sales returns, a producers' cooperative may finally be formed in order to invest the returns.

In order to promote the idea of producers' cooperatives, the government has decided that a number of demobilized soldiers, perhaps around 3,000, shall be installed with their families in some twenty pilot cooperatives with 150 soldiers each, spread evenly all over the country. These cooperatives shall receive all the financial and technical aid necessary to give them a good start, in the hope that they will then function as models to future cooperators. In this way the avant-garde of the armed struggle, the revolutionary army, will be called upon to continue the struggle for development by peaceful means. 14 
Industrial development. The intention of the PAIGC is to promote decentralized industrialization, based primarily upon the raw materials of the fields and the forest, but also upon hydraulic power and upon the bauxite deposits found in the south-eastern parts of the country. Both private, cooperative, and state ownership is envisaged. But no direct investments of foreign capital will be allowed.

The industrialization of Guinea-Bissau starts almost from scratch. only two industrial plants of some size, both located in Bissau, were inherited from the colonial period. One is a completely new (1974) and highly automatized beer and soft arink factory, employing 70 people and with a productive capacity designed to supply the entire colonial army of close to 40.000 men. The other is a groundnut oil factory, finished in two steps in 1952 and 1959 and now employing some 140 people. Its processing capacity is well below the groundnut production capacity of the country, as shown by the fact that most of the groundnut production is exported unprocessed. In addition to these two plants, there were at the time of independence only a few small rice and groundnut shellers, a number of small saws, a few carpentry and furniture shops, etc.

An important industrial project under planning is a plant at Porto Gole, east of Bissau, at the mouth of the river Gaba, where a plant with a great capacity to husk both rice and groundnuts will be installed. The husks will then be burnt to produce heat for a power station, which, in turn, will contribute energy to a groundnut oil and a soap factory.

A few major projects already beyond the planning stage are a juice factory in the old capital city of Bolama, designed to be able to produce up to 1,000 tons of juices per year, and a state sugar cane plantation of 6,000 hectares, abou't one hundred kilometers east of Bissau, combined with a sugar plant with a productive capacity of about 60,000 tons of refined sugar. This means that the exportable surplus will be about 50,000 tons, after domestic needs of sugar have been satisfied. The sugar project is planned to start production in 1980 and will employ some 2,000 workers. Construction of the juice factory in Bolama was begun in June, 1976.15

A general problem in connection with the industrialization program is finance. The government tries to obtain various types of credits, and in some cases gifts, from forelgn governments and international organizations.

Commerce and distribution, The prices of essential consumer goods are strictly controlled, with low maximum prices set for the fiye basic necessities of rice, flour, cooking oil, sugar, and soap. The prices of these five goods are so low that it is very difficult for private tra- 
ders to make a profit from selling them, at least outside Bissau, where the costs of transportation are high. Thus it is highly probable that the importance of private trade will gradually diminish in Guinea-Bissau, even without much outright nationalization.

The five basic necessities, as well as many other goods, are sold mainly through the system of People's stores (Armazens do Povo). The first Peopie's store of the liberated areas was set up as early as in 1964. Four years later there were fifteen, and a few more were added later. The function of the People's Stores during the struggle was to provide the inhabitants of liberated Guinea-Bissau with an outlet for their surplus production and at the same time an opportunity to supply themselves with the most necessary consumer goods without relying upon the Portuguese. This was of course a highly political function -- had it not been performed to the people's satisfaction, the entire credibility of the PAIGC in the people's eyes would have suffered.

Most of the rice delivered to the People's Stores was consumed by the liberation army, but there was even an exportable surplus of some rice and several other products from 1968 and onwards. This was exported to Guinea-Conakry. 16

During the war, the People's stores functioned by direct exchange, the exchange values being established centrally upon the recommendation of local cadres who knew the local opinion of a fatr price. The social purpose of this system was to satisfy elementary needs in a situation of extremely scarce resources, and in such a way that the people were encouraged to produce more.

The purpose remains fundamentally the same in independent GuineaBissau, although money is used in the exchange now. After the complete liberation of the country in 1974, the number of People's stores grew rapidly. In August of 1975 there were 72 stores, and in February of 1976 the number was $110 .{ }^{17}$ The goal was then said to be about 150 stores, spread evenly all over the country. At the same time, in February of 1976, there remained about 80 private stores, mainly in Bissau but also in a few other urban centres.

The People's stores have a central organization, with its own Director General within the state Commissariat of Commerce and Trade. This organization has a legal import monopoly with regard to other goods, it competes with other importers, but acts also as a retailer of imported goods for private traders. With the exception of the five basic necessities, private traders are allowed to add 20 percent to the price at which they buy imported goods from the central organization of the People's stores. 
It is probable, but nothing has been decided yet, that the import monopoly of the People's stores will be extended to include all goods in the future. A step in this direction was taken in December 1975, when the People's stores took over all the commercial and trading activities of the Gouveia (allied with the Portuguese Companhia União Favril, CUF), one of the two great colonial companies operating in Guinea-Bissau, the other one being the Ultramarina, which still maintains its commerce in the country. In this operation 23 sales stores were taken over by the People's Stores. The groundnut oil factory in Bissau is still owned and operated directly by Gouveia, however.

The PAIGC policies within the field of distribution and commerce now described are strong indicators of a development strategy favoring the masses of the people. They are clearly non-capitalist and socialist oriented in character, aiming as they do to break with capitalist criteria of what goods should be made available to whom at what prices.

Education. Stressing the importance of education for development is of course not very original. It would be hard to find a single national development plan in the third world that does not do this, at least at an abstract and general level. But what is unusual about the PAIGC approach to education is the consistency with which it follows from the general ideology of the movement, as well as the consistency with which it has been translated into practical action ever since the first beginnings of the struggle for national liberation.

Ideologically and theoretically, education -- and culture in general -- is seen by the PAIGC as an effective weapon of struggle against anachronistic values and beliefs, the prevalence of which is interpreted as one basic aspect of colonial cultural degradation. Another basic aspect is the general ignorance of modern instrumental knowledge. This ignorance, as well, can of course be fought against through education. Education is seen therefore both as an important part of the emancipatory struggle against imperialism and underdevelopment, and as an instrument to be used in the more immediate struggle for concrete material improvement of the people's situation. The two go hand in hand and support each other in practice. It is only analytically that they can be held apart. The ideological-strategic perspective gives strength and consistency to the daily work carried on in the many schools of the villages. And by mobilizing the people into supporting it in practice, this daily work in a sense also verifies the broader perspective from which it emanates.

Together with national defense (the cost of which is now being reduced through the partial demobilization of the army) and health and medical services, education takes the greatest portion of budgetary expenses 
(about 14 percent). There has been a dramatic expansion of educational facilities in the country during the first two years of complete independence. At the moment of independence, in 1974, there were about 15,000 students in the village schools of the liberated areas and about 45,000 students in the schools on the portuguese side. For it is a fact that the colonial authorities also expanded their school system rapidly during the last years of colonial rule, in a vain attempt to complement their military effort. But two years later, during the school year 1975/76, there were 80,000 students in the four-year primary school and 9,000 in the secondary schools. This means that well over 11 percent of the total population of the country attend school, not counting adult education and various extra courses of training. This is a very high percentage for Africa.

From a qualitative point of view it is important to note that the school system of Guinea-Bissau is highly decentralized at the primary level, with primary schools within the reach of the great majority of the children of the villages. The bottle-neck is found at the transition from primary to secondary school. This bottle-neck is still very narrow, and one urgent goal is therefore to make secondary education available at least in each of the eight regional capitals.

The lack of teachers is another difficult problem. Volunteers from the secondary school (1iceu) in Bissau are sometimes used as teachers in the villages. Another important initiative is the opening of a boarding school in Co, where the party trained teachers of the schools of the former liberated areas are offered a three-year program of studies to broaden their background. The first school in the country at a post-secondary level will probably be a teachers' college in Bolama, which might start to function in 1977.

Adult education is also an essential part of the educational program of the PAIGC. Important experiences were gained in the literacy compaign through which the soldiers of the army were alphabetized. Since then, the Brazilian educator Paolo Freirs, working in exile in Europe, has been drawn into the planning of an intensive pilot campaign in five of the country's eight regions, starting during the fall of 1976. Special teams of about fifteen members who have been taught the basic principles of democratic mass education, as worked out by Freire, will be working in the villages and urban neighborhoods and places of work. When further experiences have been gained, the state Commissariat of Education plans gradually to extend the campaign to the entire population. 
Health and medical services. It is only natural that health and medical care should be an important part of the socio-political work carried on by the PAIGC. The general goal of the movement is liberation from oppression, misery, and underdevelopment. But people must see concrete results of their efforts in order to continue to offer their political support. Improved health is one of the most immediately pressing human and social needs in Guinea-Bissau and therefore also one of the most obvious developmental and political goals of the PAIGC.

The basic principle that the State Commissariat for Health and Social Affairs tries to apply within the field of health and medical care is decentralization in order to reach out into the regions and villages, in spite of extremely limited resources both with regard to material means and personnel.

According to the plan established in 1975 for seven regions outside Bissau and intended to be fully implemented within 3-5 years, there are to be seven fully equipped regional hospitals and 12 at the level of the sector. ${ }^{18}$ of these, there were four regional and four sector hospitals that functioned satisfactorily in early $1976 .{ }^{19}$ The regions that do not yet have a good regional hospital still have smaller hospitals and a regional doctor in charge. Below the sector hospitals, there are to be 60 smaller medical posts, manned by one nurse, one assistant nurse, and one assistant mid-wife. I have no exact information on how many of these that actually existed in 1976.

During the armed struggle, a functioning system of health and medical care was built up in the liberated areas with country hospitals, sanitary posts, mobile health brigades, and the member of the village committee in charge of health and social affairs as its organizational cornerstones. The basic principles of this system have been transferred to the new peace-time system. An important improvement since the days of the war is that permanent nurses are now found at the level of the section, where they are in charge of administering simple medical care and distributing various kinds of medicaments.

The village nurses are supposed to work in close contact with the 10cal committees and the political commissar of the section in order to achieve maximum contact with the people. This is sometimes a problem, as not all nurses are as active as they are supposed to be in seeking out people in need of their services.

Another aspect of cooperation between the party and the heath services is.illustrated by a polio vaccination campaign carried out in Bissau in February, 1976. In three days, 11,286 children were vaccinated, after two meetings of information had been held to ensure the active coopera- 
tion of the local committees. The first meeting was with the members of the committees in charge of social affairs, and the second meeting was with all the members of all the committees of Bissau gathered together. 20 Similar campaigns are also being planned for the countryside.

The financial burden of the kind of extensive health and medical program necessary in Guinea-Bissau is very heavy. It was announced therefore, in March 1976, that the system of completely free medical care would be abolished. According to the new price system to be introduced, patients would have to pay from one hundred percent of the cost of treatment and medicines for the most highly salaried in the private sector to 2.5 percent for the least paid in the public sector. The people of the villages would pay a minimum of ten and a maximum of 40 pesos per consultation, according to the treatments given. ${ }^{21}$ This was presented not only as a measure to alleviate the financial burden of the state, but also as a kind of politico-pedagogical measure that would keep people from asking for unnecessary services. It was announced as a temporary measure, however.

A new judicial system. In my book on the PAIGC, I have described in detail the growth of a new and revolutionary judicial system in the liberated areas of Guinea-Bissau, based upon an evolving synthesis of traditional customary law and the modern ideological principles of the PAIGC: ${ }^{22}$ In the liberated areas, this new system completely replaced the legal system of the colonial regime.

The situation is somewhat different in today's independent GuineaBissau, where portions of the colonial system of civil law have to remain in force, for practical reasons, as long as they are not obviously contrary to the political and ideological principles of the PAIGC government. Much work, however, is devoted within the state commissariat of Justice to the extension of the system of elected People's Courts (Tritunais do povo) to the entire country.

Originally, in 1968, the People's Courts were established, with three elected judges, at the level of the village. Beginning in 1972, a kind of centralization was begun, as the court was moved to the level of the section, comprising about 5-10 villages. Under the system now being set up in independent Guinea-Bissau, this idea is maintained in principle, although there are many examples of several sections sharing one court. It is common to find one woman among the three elected judges.

Above the People's Courts, there is going to be a Regional court in each region, and on top of that there is a supreme Court. The regular Regional Court has only been established in Bissau so far, the other regions only having regional officials of justice and being temporarily grouped into three provisional judicial regions. 
The system is still under construction, and construction has begun from below, i.e. with the People's Courts of the sections. The competence of these courts is defined as follows:

"The court cannot apply jail sentences, but fines and compensations in kind. If fines are not paid, they can be transformed into forced labor, aiming at rehabilitation through work.

The court judges minor crimes, land disputes, and divorces. Its main function is to educate the masses of the people and to contribute to reconciliation..."23

\section{A few brief concluding remarks}

It appears that there is a very consistent relationship between the conditions characterizing the societal situation of Guinea-Bissau and the policies that make up the concrete development strategy of the country. We may say, in other words, that the objective situation of Guinea-Bissau does not leave much choice, given the goal of basing broad social and material improvement of conditions of life upon the country's own resources and the people's own work, willingly contributed.

Agriculture is the basis of the economy and will thus have to provide the surplus for any kind of internally generated industrialization. This requires a political organization and a state apparatus based upon and supported by the broad masses of the people. The alternative would be a neo-colonial regime with its main basis of support outside the country and relying primarily upon foreign capital for the economic development of the country. The position of Guinea-Bissau in the international capitalist system being what it is, it is difficult to see how this could be combined with broad social and material improvement under popular control.

The fact of very limited choice for the PAIGC regime -- given its developmental goals and its social basis of power, which, in turn, of course depend very closely upon each other -- does not mean that the necessary road is an easy one to follow. Continued political struggle, hard productive work, and careful international action will all remain necessary for a long time to come, if Guinea-Bissau is to remain on the road of autonomous societal transformation in the interests of the peasants and workers of the country.

In the future, the problem will then arise of how far such development can be pushed within the narrow territorial confines of Guinea-Bissau alone. Sooner or later it will become necessary to coordinate policies systematically not only with Cape Verde but also with other west African regimes whose developmental options may differ from those of Guinea-Bissau. This difficult theoretical and political problem was never directly confronted in the writings of Amilcar Cabral, nor has it been dealt with systematically by any other leader of the PAIGC. But 
following the logic of Cabral's political thought, the problem of continued development in the direction of socialism, after the struggle for independence has been gained, would have to be defined as simultaneously national and international. The difficult reconciliation of these two levels of analysis and action cannot be worked out in the abstract alone, however.

How far can we generalize from the specific conditions of GuineaBissau to other situations of societal transformation, in the third world or perhaps even more generally? I am only raising the question. A scientifically adequate answer requires more careful methodological consideration than it is possible to give it in this paper.

It would appear, however, that the importance of political organization and education -- political mobilization -- in the context of GuineaBissau is not specific to this particular country. If social and material improvement does not come spontaneously, how would it in fact be possible to achieve it without conscious action by those to whom it has previously been denied? ${ }^{25}$

It is a different matter that the conditions making for such mobilization differ greatly from country to country and from situation to situation. Eleven years of imposed armed struggle for national liberation made the need for political mobilization much more obvious and thus easier to meet in Guinea-Bissau than in most other African countries. The need for political mobilization may be equally great in other countries and situations. Still there is no social determinism guaranteeing that it will occur. 
1. See Boletim Mensal de Comercio Externo, July 1975, Bissau, Comissariado de Estado de Desenvolvimento Económico e Planificação (mimeo), 1975, table 13.

2. See No Pintcha (this means approximately "forward" in Creola and is the name of the official tri-weekly newspaper published in Bissau by the State Commissariat of Information), March 16 and $18,1976$.

3. Boletim Mensal de Comercio Externo, July 1975, table 1 and 2.

4. Same, table 13 .

5. Same, tables 5 and 6 .

6. Same, table 12 .

7. Same, January-June 1975, and summarizing article in No Pintcha, December 20, 1975.

8. Palavras de ordem gerais do camarada Ami lcar Cabral aos responsáveis do partido, Novembro de 1965, PAIGC, 1969, p.23 (translation into English by this author).

9. See No Pintcha, February 29, March 2 and 4, 1976, about the nationalization and the new currency, and June 22, 1976, about the changing attitude of the portuguese government.

10. See, for instance, No Pintcha, December 9, 1976, about the need "to reinforce our political work at all levels..."

11. Interview with Francisco Coutinho, Director General of the People's Stores, on February 7, 1976.

12. The official prices were confirmed by Decree of the Council of state Commissare, No. 16/74, published in the Boletim Oficial, No 4, January 25,1975, p. 41. A year later, it was announced in No. 51, December 20,1975, p. 540 , that the prices would be the same in 1976 .

13. The law on the nationlization of the land of all national territory has been published as Law No. 4/75, Boletim Oficial, No. 19, May 10, 1975 , p. 214 .

14. See, for instance, Anteprojeto de formacão de uma pre-cooperativa, Bissau, Comissariado de Estado da Agricultura e Pecuária (mimeo), 1.976 .

15. No Pintcha, June $19,1976$.

16. See Rudebeck, Guinea-Bissau. A study of political mobilization, Uppsala, Scandinavian Institute of African Studies, 1974, pp. 178186.

17. See note 11 .

18. Situation actuelle, Janvier 1975 , Bissau, Subcomissariado de Estado da Salde e Assuntos Soclais (mimeo), p. 4.

19. Interview with Manuel Boal, Director General of the State Commissariat for Health and Social Affairs, on March 9, 1976. 
20. No Pint:cha, February 26, 1976.

21. No Pintcha, March 13, 1976.

22. Rudebeck, 1974, pp. 137-143.

23. No Pintcha, April 15, 1975 (translation into English by the author).

24. See Cabral, Revolution in Guinea. An African People's Struggle, London, Stage 1, 1969, pp. 73-90; and Rudebeck, 1974, p. 83.

25. See Rudebeck, 1974 , pp. $230 \mathrm{ff}$., for a discussion of the concept of mobilization. 
Pertti Multanen

PROBLEMS OF SOCIALIST ORIENTATION IN NASSER'S EGYPT

The anti-imperialist, anti-feudal national liberation revolution, which took place in Egypt in 1952 was an event the significance of which was not limited to Egypt or merely to the African continent, but greatly affected the ripening national liberation movement in the whole world. Egypt's development after the revolution and especially in the 1960 's provided a foundation for keeping the country as one of the cornerstones of the national liberation movement. In Egypt's experience we can see very clearly the most central difficulties, which the countries on the road of socialist orientation are faced with. The development of Egypt during the latest few years demonstrates for its part that the success made during the socialist orientation - especially in the economic sector - can be used in various political situations as a component of the restauration of vapitalism or as a component of speeding up the development of capitalism.

Our aim in this paper is to briefly sum up the major events in the economic and political development of Egypt in the 1950's and 1960's as a basis for understanding the radical changes in the 1970's - the changes, which had the most negative influence for the socialist orientation of Egypt and which actually interrupted this path of development in Egypt.

The economic reforms after the revolution

The agricultural reforms. The 1952 revolution in Egypt was by nature an bourgeois democratic revolution. The nationalist-minded officers, who led the revolution reflected in their actions the class-interest of various groups of the national bourgeoisie. The most dangerous opponents of the officers were the feudalists - the former hegemonic rulers of Egypt. The officers easily understood that the power of the feudalists was in the land concentrated in their hands. This very background antifeudalism - must be kept clearly in mind when analysing all the agricultural reforms in Egypt after 1952.

The law of agricultural reform september 9, 1952 reflected this combination of class forces - the struggle of the new rising class, the national bourgeolsie, against the feudal-class. In being directed against feudalism, the reform law was at the same time directed against the most important social support of Eqiptian monarchy. With this agricultu- 
ral reform the military regime strove on the one hand to secure the support of the peasants and agricultural workers, but on the other hand - and this is a very important aspect - they strove to strengthen their position in rural districts by facilitating the birth of a new strata of landed bourgeoisie. The fruits of the agricultural reform fell firstly into hands of the rising group of kulaks. 1

A very characteristic and candid expression of the opinions of the military regime can be seen in the words of Gen. Naguib (the leader of the Revolutionary Council at that timel in which he estimates the results and aims of the 1952 agricultural reform: "A little is better than nothing, and although only a minority of each village is able to purchase additional land, the results, we think, will be worth while. The minority will provide us with the village leaders of tomorrow." 2 An important objective of the military regime was to use the agricultural reform to weaken the positions of communists in the countryside. ${ }^{3}$

As a whole, the 1952 reform strengthened the landed bourgeoisie. The limit of the maximum acreage of landownership was still high enough to give feudal landlords a possibility of keeping huge amounts of land in their hands - the farms of the capitalistic big landowners were left untouched. The small landowners received very little benefit from the reform, and the landless peasants received no land by this reform. Only the richest group of feudal landlords substantially lost their positions. So the 1952 reform did not over-step the boundaries of a limited bourgeois-democratic reform. It was directed against feudalism, but for the development of capitalism. ${ }^{4}$

The 1961 agricultural reform in its main features followed the lines marked out in 1952. The antifeudalist direction deepened and large groups of feudal landlords began to lose their positions. The direction of strengthening the land bourgeoisie was also continued. Semifeudal elements kept in their hands strong economic and political positions. The strengthening of the positions of the landed bourgeoisie brought for the peasants a new heavy yoke to bear. No real changes took place in position of the agricultural workers, in spite of the new legislation. The situation in which the new kulaks and semi-feudal elements had the countryside in their hold made the new legislation into empty words. The certain progressive elements of the reform remained in the shadow of the contradictions of the totality.

When comparing the results of the 1952 and 1961 reforms we can say in summation that besides the limiting of the maximum of land possession there were no radical changes in the agricultural structure of Egypt. All of the measures of agricultural reforms were realised in the conditions of private ownership of the land and after both reforms there 
still remained over 30000 big landowners, who had in their possession almost $1 / 3$ of the agricultural land of Egypt. 5

In the summer of 1969 a proclamation concerning new limitation of maximum acreage of land was given, nevertheless the death of president Nasser in september 1970 changed the political situation in the country and already in autumn 1971 the new government made decisions that began to negate the former reforms. ${ }^{6}$

As we can see the solution of the agricultural question in Egypt is still ahead. Indeed the countryside became a weak chain of Egypt's revolution. The total preservation of private ownership of the land, the rapid progress of the capitalistic relations of production in the countryside and at the same time reinforcement of a petty-bourgeoisie mentality slowed down the ideological development in the country. That kind of situation can not help reflecting the exacerbation of the class struggle in the rural districts. The spontaneous struggle of the rightless peasants in the 1960's sometimes took the form of open collisions between the landowners, and the peasants and agricultural workers. ${ }^{7}$ Also these events and the way in which the peasants' struggle was repressed showed how the interests of the landowners and the government linked up. Uneducated, illiteral and without political experience and organizations, the peasants naturally were not able to rise into an efficient struggle against the exploiters.

A characteristic feature of the land reforms of Egypt was the fact that the peasantry could only to a very limited extent - if at all participate in the realization of the reforms. So the political mobilization of the millions of peasants did not take place. place. However, it can easily be understood that without an active participation of the peasantry no profound agricultural reform can be realised.

Nationalization of the big industry. Concerning industry the measures favourable for socialist orientation were more determined than those concerning the agricultural sector. However, analysing the situation in industrial sector of Egypt closer we find behind the measures of nationalization the same background - the same catalyst - as in agriculture antifeudalism.

A characteristic feature for the development of capitalism in Egypt before 1952 was the very fact that the richest group of the Egyptian capitalists was very closely linked with the feudal or semifeudal landownership. The interests of the national bourgeoisie were in crushing the power and influence of this top level of the bourgeoisie - the "feudal" bourgeoisie. In the industrial sector we can find the same fe- 
nomenon as in agriculture - the rapid birth of a new bourgeoisie strata.

The politics followed by the military regime during the first years after the revolution - till the year 1961 - can be characterised as a period of state capitalism. During that period the interests of national capital corresponded with the measures of the military regime and we can say without a doubt that the 1952 revolution opened a broad path for the strengthening of the position of national capital.

Also the nationalization of the Suez canal zone, which meant a remarkable limitation of foreign economic power was a measure along the lines of state capitalism policy. The "Egyptianization" of English and French possessions in Egypt, followed by the nationalization of the canal zone strengthened national capitalism because the "Egyptianized" enterprises and possessions as a rule were given to Egyptian capitalists. On the other hand, the special conditions created by the imperialist aggression forced the military regime to search for the means of planning and directing the development of national economics and in that way dictated the enlargement of the state sector.

In the first years of the 1960's a large wave of nationalization took place, after which the state sector clearly had a leading position in the industrial sector of Egypt. By the measures of nationalization the power of the richest group of the big bourgeotsie and a certain part of the middle bourgeoisie was also touched. However, there still remained large manouvering room for private capital. The weight of private capital in the national economy was still large and in many sectors (for instance in building construction, trade e.t.c.) private capital held decisive positions. ${ }^{8}$ Private capital also retained a certain degree of influence in the state sector - it for example had shares in nationalised enterprises, the former owners remained, as a rule, the directors of the nationalized enterprisers e.t.c.. We can say that as a whole private capital was still in possession of enough important fountains of enrichment to provide for the birth of a new big bourgeoisie.

Without a doubt state planning and directing of the national economy were new trends in Egypt's economics. The realization of the potential possibilities, however, very greatly depended on the subjective factor of the revolution - on persons in the political leadership. The relations between the political leaders and the people remained on a nonorganized, more or less spontaneous level. In addition certain features in the structure of the administrative apparatus and especially in the structure of the administrative personel were a strong barrier in the way of implementing plans. As a whole, deep contradictions in the structure of the Egyptian society created very unfavourable conditions for 
the new trends in economics - for the birth of new structures.

A good example of these contradictions was the case of affairs in the Ministry of 'Planning of Egypt. The Ministry of Planning - one of the central organs in bullding the new society - became in the 1960 's a outpost of counterrevolutionary elements. The situation was paradoxical, but explains on its part why the potential possibilities of states to plan and direct the development of economics were not realized. ${ }^{9}$

\section{Social implications of the economic reforms.}

The process of socialist orientation is always closely linked with the class struggle and with the concrete changes in the balance of classes. In the final hand only the growth of the proletariat and its transformation into a "class for itself" and into a vanguard of the struggle for liberation by its party and in the leadership of its party can give a full guarantee of the success on the difficult path of socialist orientation.

Which kind of changes in the balance of classes took place in Egypt after the revolution?

The proletariat. The difficult circumstances created by colonialism slowed the development of the class consciousness of the Egyptian proletariat. The growth of the class consciousness was also hindered by the fact that there was not a strong Communist movement in Egypt. Just a few years after its foundation the Communist party became an object of strong persecution, and since then the marxists of Egypt have been not able to form a solid Communist party.

The trade union movement grew rapidly in the 1930's and especially in the 1940's, and became a strong factor of social power. It has never, however, had much room to manoeuver. ${ }^{10}$ The Egyptian proletariat does not have strong, experienced organizations of class struggle.

The military regime was able to utilize the weak level of organization and class consciousness of the proletariat and make the growth of the consciousness of the industrial proletariat somewhat slower by keeping them, especially in the first years after the revolution, more or less in a privileged position, especially compared with the large group of agricultural workers. The relatively small number of the industrial proletariat and on the other hand the pauperization of the agricultural proletariat created a difficult situation for uniting the rows of the working class.

According to official Egyptian statistics for 1968-9 worked in agriculture 3.964.900 persons and in industry 890.700. During the 1960's the 
absolute increase of the workers in agriculture was bigger than that of the industrial workers. II It must also be noticed that only a small part of the workers in the industrial sector are really an industrial proletariat. The majority of the workers of this group in the statistics worked in many kinds of little workshops and had very close ties with the countryside and a weak class consciousness. To the total number of the Egyptian proletariat must, however, still be added rather large groups of construction and transport workers. The whole amount of these two groups was almost as large as the group of workers under the title "industrial workers". 12

The formation of the Egyptian proletariat is still going on. The fact that a remarkable part of the working class has close ties to countryside can not help reflecting negatively in the process of growth of the class consciousness and in consolidation of the rows the working class. In the Egyptian situation close ties of a part of the working class to countryside means also ties to a petty-bourgeoisie conception of the world. These facts for their part make the ideological development a difficult process and weaken the unity of the workers. Of course the situation would be much easier if there should be a mass party of proletarian type. The state of the Egyptian proletariat and the lack of its mass organizations shows us also the fact that the revolutionarydemocratic leaders of Egypts socialist orientation did not recognize the central meaning of the proletarian class for socialist orientation.

The bourgeoisie. As a class the bourgeoisie in post-revolutionary Egypt was not threatened. However, within the class of the bourgeoisie important changes took place. The bourgeoisie as a class became "younger", when the positions left empty by the top level of "feudal" bourgeoisie were filled by new recruits coming from the middle- or petty bourgeoisie or from the strata of big landowners. Also recruits from the highest ranks of officials and government employees and from the ranks of officiers filled the empty posts in the rows of the bourgeoisie. As a whole, the bourgeoisie suffered a loss during the years 1961-1964 when its most notable, traditionally influential and the richest representatives lost their possessions and their power, but at the same time the reproduction of the class was guaranteed by the recruits. Feudalism suffered heavy losses and so did the old big bourgeoisie connected with the feudalism, but by these manoeuvres there was opened a way to a more rapid development of capitalism.

The peasantry. The former methods of exploitation, feudal and semi-feudal, began - as we saw - after 1952 to be rapidly transformed into capitalistic ones. Besides these, nevertheless, the hold of feudalism and the re- 
lations characteristic of feudalism are still strong in the countryside and in many cases are even stronger than capitalistic ones. This kind of situation can not be changed for the better before all the lands owned by the big landowners and the capitalists have been given into the large majority of the peasants. The present situation of the peasantry condemns the peasants to suffer from continual exploitation, from the loss of lands and from the growing differentiation of the peasantry.

A progressive element in the agricultural reforms of Egypt was a certain increase in the state control of the agricultural sector. This possibility remains, however, merely nominal, while the state's political power is in the hands of petty-bourgeoisie and bourgeois-bureaucratic elements. The bourgeois-bureaucratic elements naturally aim to advance the development of capitalism in the countryside. The petty-bourgeois leaders, even revolutionary democrats, strove to solve the agrarian question by a compromise, i,e. by eliminating the hunger for land (usually by forming state cooperative farms, which eliminates the problem only partly) and by preserving the private ownership of the land. The petty-bourgeois leaders follow also in this question their ideal of transforming all the members of the society into small-holders. It must be added that a compromise according to this ideal usually suits the bourgeoisie very well.

As a summary we can say that the most visible change among the peasants after the 1952 and 1961 reforms was the birth of a strong stratum of kulaks and capitalistic enterprisers. As a rule, the members of this new stratum were recruits from the peasantry, but also resident of cities (officials, shopkeepers e.t.c.) who bought the land lost by the feudalists.

The feudal class. As a class the feudalists have suffered a loss. This, however, does not mean that - as mentioned earlier - there would not remain strong survivals of feudalism in Egypt. The transformation of the representatives of the feudal class into capitalistic enterprisers did not progress directly, without very strong counter-attacks by the feudalists, without their attempts to maintain or to restore the old order. Even in the second half of the 1960 's there can be found many facts, which prove that many feudals succeeded in avoiding the laws of the agricultural reforms. ${ }^{13}$

\section{New features in Egypt's social evolution}

The following three characteristic features can be clearly noticed in the post-revolutionary social evolution: a rapid increase of the middlegroups of society and especially a very rapid growth of the petty-bour- 
geoisie, a rapid growth of bureaucracy and administrative personnel and the tendency of the administrative personnel to turn into a bourgeoisie.

The growth of the petty-bourgeoisie in the countryside is directly tied up with the nature of the agricultural reforms. The growth of the petty-bourgeoisie in the cities has a more complex background, but a very rapid growth of the number of shopkeepers and persons in various kinds of services is a main foundation of this phenomenon.

The growth of bureaucracy during whole the postrevolutionary period, but especially in the 1960's was a very rapid process. An Egyptian, Adel Ghoneim, gives in his article the following statistics about the increase of the number of administrative personnel. In the fiscal year 1962-3 there were 770.312 government officials in Egypt - in the fiscal year 1966-7 the number of them reached 1.035.747 persons - an increase of 348 in three years. ${ }^{14}$ The growth of bureaucracy had a very unfavourable influence for socialist orientation of Egypt because of the fact that it was closely linked to the process of the transformation of the top level of the officials into a bourgeoisie. The background of this tendency was especially in two factors. Firstly: the structure of the administrative apparatus was as a rule the same as before the revolution and the very same officials who were in high posts before the revolution remained in their posts. Secondly: the recruits for the rapidly inreasing administrative personel came usually from the petty- and middle-bourgeoisie or from the officers. The basis for turning the officials into a bourgeoisie and reactionary force remained.

Problems and contradictions of Egypt's socialist orientation

In conclusion we once again sum up some of the central reasons for the fact that the path of socialist orientation of Egypt ended unsuccessfully, so that socialist orientation could be interrupted and the country again was directed into a way of capitalistic development.

One of the main problems of the development on the way of soclalist orientation - submitting of the private capitalistic sector to serve the goals of socialist orientation- was not successfully solved in Egypt. The idealistic views of the political leadershlp about the existence of "non-exploitative" capital e.t.c., insufficient state control of private capital, the development of the agricultural sector along the lines of capitalism, insufficiently decisive measures against the survivals of feudalism and big landownership, and others remained for private capital a too large space to move. The situation as a whole created that kind of pressure, which the political power cold not stop any more. And the political leaders of Egypt did not even seriously try to stop 
the process of widening of the manoeuvering room of private capital. Actually there were no measures in post-revolutionary Egypt to control private capitalism as such. Capitalism as a phenomenon and as a mode of production was approved and even supported. It was only a certain part of the old big bourgeoisie which was not approved in Egypt.

The class character of national democracy in post-revolutionary Egypt remained saturated with the petty-bourgeois mentality. The revolutionary democrats of Egypt could not recognize the role of the proletariat in the liberation revolution. The cooperation between the revolutionary democrats and marxists remained on an insufficient level. The state admistrative apparatus remained the same as before the revolution and filled with counterrevolutionary elements. The political leaders did not even seriously try to change the structure of personnel of the government officials or to eliminate the counterrevolutionary elements in the personnel.

The Egyptian revolution did not build its organs of defence. However, the results gained by a revolution can not be defended without a special Jrgan of defence, the significance of which is to crush the attempts of the exploitative classes to defend and to restore the old order. Also successful progress on the path of socialist orientation is impossible without the means to defend the results of the national democratic revolution and to fight against the attacks of the counterrevolutionary forces.

In the leadership of socialist orientation of Egypt there was not a party, which should have been able to lead the country through the extremely difficult path of socialist orientation. The Arab Socialist Union was not able to do this because of the lack of the ideological consciousness, solidness of its rows and because of the fact that it had serious organizational weaknesses. In the last few years of the 1960's there was a discussion inside the ASU on the formation of a real fighting party. That kind of vanguard-party was not, however formed, although the main condition of progress on the road of socialist orientation is that it is absolutely led by a firm, experienced and ideologically armed party. 
NOTES

1. Agrannye reformy $v$ stranah Vostoka, Moscow 1961, pp. 154-155.

2. Cited in: Harris, George I. (ed.I: Egypt. Country Survey Series, New Haven 1957, p. 217.

3. Anouar Abdel Malek: "Nasserismo y Socialismo", Nasserismo y Marxismo, Buenos Aires 1965, p. 165.

4. Agrarnye reformy, op.cit., pp. 154-160.

5. Sotsialjno-ekonomitsheskije posledstvija agrarnih reform v razvivajushihsja stranah, Moscow 1966, p. 139 .

6. See for example: Rydberg, Ingvar: De arabiska revolutionerna, Stockholm, 1975, pp. 215-218.

7. Beljaew, E.M. - Primakow, A.P.: Egipet" vremja prezidenta Nasera, Moscow 1974, pp. 180-182.

8. Ibid., pp. 172-173.

9. Ibid., pp. $331,334-336$.

10. Issawi, Ch.: Egypt in the mid-century (Russian ed.), Moscow 1958, pp. 270-272.

11. Statistical Abstract of the United Arab Republic 1951/52 - 1969/70, Cairo 1970, p. 174 .

12. Ibid. 
Mai Palmberg

THE POLITICAL ROLE OF THE WORKERS IN TANZANIA AND ZAMBIA

The working class in the discussion on non-capitalist development

The theoretical discussion on "non-capitalism" or, as it is increasingly called, "socialist-oriented" development contains both an affirmative and a negative assertion. On the one hand, it is a positive assertion of the possibility to by-pass Capitalism in the Third World. On the other hand, it proclaims the impossibility for a transition to Socialism in these countries in the near future. The restricting factor, according to this view, is the lack of a fully developed working class, capable of taking the political leadership.

The arguments are that the working class is not today "fully developed" because of its numerical weakness, the low level of literacy and education, the relatively low number of industry workers, and the persistent ties to the countryside. The latter fact means that the workers do not conform to the general definition of a worker as a person who is forced to sell his labour power, since he has the option of returning to his village, and in fact does so at intervals.

If all that was needed as precondition for a transition to Socialism was the eradication of these weaknesses, then "non-capitalist development" was just the name for a strategy of industrialization. Assertions that a low level of productive forces are unsurmountable obstacles to a transition to Socialism would be consistent with this view. But the crucial question, which must be closely studied, is the political development of the class alliances, and the role of the working class in relation to this process. This is the logical result of the fact that proponents of "non-capitalist development" argue that the struggle for Socialism has already started with the choice of "the non-capitalist path" at the initiative of "revolutionary democrats".

In "Africa Makes a Choice" Gleb Starushenko writes:

"The state-political form to be established in a developing country setting out towards soclalism depends primarily on the nature and balance of the internal class forces and social strata. If an economically backward country has the prerequisites for socialist revolution, including a well developed working class capable of leading the peasantry and an influential Marxist-Leninist party that can guide the struggle of these classes, and if the revolution is victorious, then a socialist state is formed. This is what happened in the Democratic Republic of Vietnam and the Korean People's Democratic Republic. In this case, as already pointed out, pre-socialist (non-capitalist) development proceeds within a Socialist state." 1 
One conclusion from this is that the level of the productive forces is not decisive for the political form of the socialist orientation. Another conclusion, not explicitly drawn by starushenko, is that the development of the state and political form is one important aspect of the overall development, and that the question of ideology and leadership is a vital aspect of the ultimate victory of the Socialist orientation. In much of the discussion on non-capitalist development only the social content is discussed thoroughly, and one gets the impression that the evolvement of a Socialist political form is a function of the raising of the productive forces. ${ }^{2}$

This paper attempts to redress the balance and substantiate the view that a) the development of the workers' organisations in Africa must be seen in a historical context, recognising the special features arising from their colonial origins, b) that the crucial question during Independence is the role assigned to the workers and the workers' organisations by the ruling group.

The latter question is often overlooked when it is assumed that the workers are the basic force in the "broad national front" which is the social base for non-capitalist development. Thus Iskenderov writes on Africa that

"even in countries with a relatively developed working class the proletariat's hegemony in the national liberation movement should not be regarded as something "secure", as something predetermined once and for all. It is won in struggle. The decision of when and how fast the working class can assume leadership depends on the situation in the given country, on the strength of its influence on the masses, on how well it succeeds in winning over non-proletarian forces..."3

But in order for the working class to take the initiative, invite alliances, and when the moment comes, "assume leadership" there must be some room for independent workers' action (as distinct from reaction, which no government can stop). And in all African countries, including the ones mentioned as examples of non-capitalist development (Guinea, Congo-Brazzaville, Somalia, Algeria, Ghana under Nkrumah, Egypt under Nasser, Tanzania) there is no allowance for independent workers' organisations, nor is political activity outside the single party allowed.

The question we must ask is what role the workers play in the political development. This paper attempts to do so by a look at the development in Tanzania and Zambia.

Tanzania has been mentioned as one example of a country on "the non-capitalist path", and this is in itself a compelling reason for examining the evolving role of the workers. Zambia, on the other hand, is one of the few countries where there is a comparatively large working class, so there the basic precondition for a socialist-oriented 
development has been fulfilled. There is also an unusually large state sector, and the proclaimed aim of the government is to curb the development of indigenous Capitalism - albeit an intention clothed in moral terms, with a parallel encouragement in credit policies etc. working in exactly the opposite direction.

On the basis of an examination of the 1968. and 1969 economic reforms in Zambia, when the state took over 51 per cent of the shares in major enterprises in building supply, brewery, road transport, and above all, in the huge copper mining enterprises, Hans Kramer concludes that "if one takes the criteria usually associated with 'the non-capitalist development' --- Zambia fulfills them completely". "Actually I have seen no other references than Kramer's to Zambia as a non-capitalist country. But Starushenko writes that Zambia (along with Dahomey) is an example of a country which has rejected Capitalism as a system, and "are already carrying out reforms that can later lead to their adopting a socialist orientation". ${ }^{5}$ A comparison of Tanzania and Zambia, ${ }^{6}$ two countries with striking similarities in their basic policies, can serve as a useful reminder of the risks in separating the question of the social content from the development of political forms.

In the next section I will add some comments on the crucial role of the political leadership, and how its class character, and thereby the development strategy of the country in question, can be determined. With this basic research strategy in mind we discuss, in section IV and $V$, the formation of the working class in Tanzania and Zambia, and the workers' organisations and development policies.

\section{Revolutionary democrats or an administrative bourgeoisie?}

The question we will be asking is: What is the relationship between the workers and the groups and strata controlling the state? First, we will take a brief look at the discussion of this latter category.

Their classification in terms of class origin is no problem. In most of the newly-independent states the group of people taking over the political leadership, where the colonial administration took off, had been working as civil servants in the colonial administration, or as teachers at the missions, often also engaging themselves in small trade. They can be classified as "petty bourgeoisie" or "intermediate strata". These groups are not a major social force by themselves, 1.e. they cannot be the motive force in social changes of fundamental character, because they do not play a central role either as owners or producers in the production of goods that provide the material foundation for the society. Historically their role in the social process is 
characterised by a vacillation between the social forces, the owners of capital and land, and the working masses.

The assessment of their tendencies displayed so far, and the assumptions on their future role, differ widely. On the one hand, there are statements that "the revolutionary democrats" or "the national bourgeoisie" (as opposed to the comprador bourgeoisie) almost inevitably will pursue anti-imperialist policies, restricting the power of foreign capital and instituting reforms for the benefit of the masses. Assertions that non-capitalist development is "a compelling necessity" 7 and the law of development adds to such optimistic oversimplification.

Two irreconcilable views of the dominant tendencies in the Third World are put forward by scholars, who agree only on the necessity to foot the analysis in Marxist theory, but not on how to do it, who does it, and with what results. The optimists, to which most proponents of the theory of non-capitalist development belong, see a powerful national liberation movement sweeping over Africa, Asia, and Latin America, defined thus:

"The national liberation is the highest, final state of the national liberation struggle.

The main issue in any revolution, including the national liberation revolution, is that of state power. The transfer of state power from the hands of foreign monopolies or their placement to the patriotic, progressive forces of a formerly oppressed nation is the basic feature of every national liberation revolution".8

This development, according to the document of the Communist and Workers' Parties 1969 is "ranking second in historic importance only to the formation of the world socialist system".

on the other hand, we have authors like Samir Amin, who deny the presence of any progressive development in the Third World, except in countries like china and Vietnam, where a Communist party has been the leading element in an armed liberation struggle. In the rest of the Third World we only find variants of "an administrative bourgeoisie", a self-enriching group which in its bid for their own power use the state to create an economic base. Since the prospects for indigenous, self-sustaining Capitalist development are non-existent because of the neo-colonial situation, their only alternative will be to be "junior partners" with foreign capital. The enlargement of the state sector is usually undertaken in partnership with foreign capital, through management contracts and/or minority share-holding agreements, and thus "the administrative bourgeoisie" are linked ever closer to the ruling classes of the Centre. They serve as "a transmission link".

If the only question we were interested in was an overall assessment of the basic tendencies in Third World development, then the theory of 
non-capitalist development was irrelevant, and we would conclude that those who are busy uncovering the pattern of neo-colonialism and structural dependence come closer to the truth. But our interest is in the possibility of overcoming underdevelopment and breaking the links of neo-colonial dependence, and therefore we are rightly concerned with the exceptions, while we must give credit to the students of dependence for their analysis of the structural pattern of external links. This tells us much about the problems, but nothing about the actual struggle. An analysis of a concrete Third World country which focuses on the nature of the political leadership and the state bureacracy and its links to foreign capital only fills in the contours of the phenomenon of neo-colonialism, the essential features of which are already described in a number of elementary books. But only this kind of descriptive analysis is not of use for the discussion of actual development strategies.

Only by examining the alliances between the ruling group and the major social classes in the Third World countries themselves, can we begin to understand the real tendencies of development. This is an often neglected task. This can be done either through studying the effects of policy decisions in an effort to assess what groups and classes benefit from them. It can also be done by studying the participation of the different groups in the decision-making process and the execution of policies. And finally, where there is an organisation of a group or class, like the trade unions, one can study the role assigned to this organisation in the development process. This is what I attempt to do here. One way of "testing" the result would be to make parallel studies from the two other angles, but this paper is only one piece in the puzzle.

Before turning to some historical data on the development of collective labour action, and a discussion on the relationship between the national leadership and the workers, we will discuss some of the possible objections to the whole exercise of treating the workers as a potentially important factor in the development strategy. The most important of these objections can be listed as follows:

i. "Class analysis might be relevant in the developed countries, but certainly not in the Third World, where other cleavages like that of tribe are more important".

ii. "There is no working class in the Third World, at least not in Africa, but only peasants, of whom a small part temporarily work as migrant labour. Their roots are in the villages".

iii. "The workers in Africa are not exploited, but are part of the exploiters, a labour aristocracy, and a privileged elite". 


\section{The relevance of class analysis}

First, let us clear up one issue, which has caused considerable confusion. The contention that a class analysis is essential to the understanding of the socio-economic development and alternatives in Africa is not identical to saying that we must expect to find the same class categories in Africa as in Western Europe or North America. This should be self-evident but unfortunately much of the rejection of class analysis is as primitive as this.

By claiming that class analysis is essential we are simply saying that a) there are classes in Africa, and the formation of classes is one of the central objects of analysis of these social formations, b) that the relation to production determines, here as elsewhere, the social behaviour of various groups.

The proper place of "tribalism"

Those who dispute this usually claim that such cleavages as tribal divisions are more important than class. Whereas I think that questions of ethnic origin often have to be taken into account in analysing the concrete situations, they cannot become intelligible unless they are understood in the context of the uneven development and class formation caused by Capitalist penetration. A position similar to that of the Chagga in Tanzania as a comparatively favoured group was held in zambia by people from Nyasaland (Malawi) who often were found in positions of "the new petty bourgeoisie", whether in the mines or in colonial administration or missionary activities. The penetrating analysis made by A.L. Epstein of the socio-political development of one of the urban areas in the coppervelt in the mid-fifties still stands as an exemplary treatise of this question. Discussions on the so-called "tribal conflicts" on the South African mines, which have abounded in the past two years, would probably benefit from the way of looking at things that Epstein introduced.

The earlier establishment of missionary stations in Nyasaland gave the Africans there a lead over their fellows in Northern Rhodesia. "For a long time most of the African clerical posts on the mines and in the government service were filled by men from Nyasaland". 10

Also, many of them already had experience from working underground in the mines in Southern Rhodesia when the copper mines opened in Northern Rhodesia. Many of these were trained by the Companies as a corps of instructors of the other workers. 11

The Nyasalanders formed "a very obvious elite" in the urban community, whereas the Bemba people from the Northern province supplied most 
of the lowest categories of mine labour. "The Lozi (from Barotseland, now the Western province) and the Nyasalanders made up the whole corps of the mine clerks, at least in the beginning. The very fact that the Nyasalanders were referred to a "Nyasalanders", and not as Henga, Tonga, Tumbuka etc. (tribes in Nyasaland) makes it evident that we are not dealing with a situation of "resurgent tribalism". The inter-tribal relations are a function of the developing social system of the towns, in which as a result of historical accident the lines of an emerging class structure are tending to coincide with tribal divisions". 12

Epstein writes that "a source of confusion in the discussion on tribalism is that there is a failure to distinguish those sets of relations in which tribal factors remain important, and those in which other factors are dominant". 13

Epstein found that tribal factors were important in interpersonal relations, and the system of Tribal elders instituted by the companies did have some success in the civil administration of such matters as marriage disputes and thefts. But as soon as there was a conflict with the Companies, the tribal organisation ceased to have relevance for the workers, who regard the Elders as stooges of the Company. This was the case in the 1935 strike by African miners against the increased poll tax, and it was repeated in 1940, when African miners struck after a successful strike of European mine employees. Again the issue was taxes - African miners by this time paid as much as one month's pay in tax. The reply was a confrontation with the police, who killed 17 miners. Only after this did a Commission report lead to the set-up of works' committees to supplement but not yet replace the tribal system.

\section{Tribal politics}

It is a different matter altogether that tribal affinities may be, and are, exploited in the search for loyal support, where no other such basis can be found. Thus in Zambia, day-to-day politics often must be explained by the recalling of ethnic loyalties and jealousies. These "tribal conflicts" on a political level are not examples of a consistent behaviour of ethnic groups as collectives. Significantly, this mode of playing power politics is more likely to occur in Zambia than in Tanzania. In Zambia Capitalist penetration has been more thorough, and has created hierarchical relationships between groups, which formerly only had horizontal relationships. Some of the ethnic groups are large and cohesive enough to make it possible to play tribal politics (the Lozi, the Bemba, the Ngoni, Nyanya and the Ila-Tonga), whereas the common bond of language that Tanzania has in Swahili is lacking. 
Migrant labour - peasants in disguise?

\begin{abstract}
"Migrant labour", the form that labour utilization initially took in tropical Africa, meant that the workers retained their ties to the home village, and returned there after a period of 6 months to three years. To put it in theoretical terms, they were simultaneously participants in two different modes of production, on the one hand in the enclave of Capitalist mode of production, on the other hand in the traditional modes of production. Does this mean that there is no working class?

This is precisely the argument in Arrighi's and Saul's known discussion on the "labour aristocracy".
\end{abstract}

"Owing to an overallabsence of population pressure on the land in most African countries and to the capital intensive character of production, the wage working class is polarized into two strata. Wage workers in the lower stratum are only marginally or partially proletarianized as, over their life cycle, they derive the bulk of the means of subsistence for their families from outside the wage economy. Wage workers in the upper stratum, generally a very small minority, receive incomes sufficiently high (say three to five times those received by wage workers in the lower stratum) to justify a total break of their links with the peasantry. This is a type of. "optional proletarianization" which has little in common with processes of proletarianization resulting from the steady impoverishment of the peasantry. We therefore feel justified in considering wage workers in the lower stratum as part of the peasantry (which participates in the wage economy through labor migration) and in including the upper stratum with the much more important "elites" and 'sub-elites' in bureaucratic employment in what we have called the 'labor aristocracy'."14

Here, Saul and Arrighi argue that (I) if the workers have any revolutionary potential it is in their role as peasants, and (2) the reason why the part of the workers who are not half-peasants have no revolutionary potential is their "optional proletarianization". They seem to omit the fact that the institution of migrant labour was an intentional policy of the companies in collaboration with the colonial administration, and its existence thus not necessarily related to a lack of impoverishment of the peasantry. There were two primary reasons for this policy. Firstly, the existence of traditional modes of production made it possible to transfer part of the cost of the reproduction of labour to the subsistence economy. Secondly, there was fear that a fully proletarianized African working class, or "urbanisation" to use the colonial jargon, would be a threat to stability and order.

Migrant labour was instituted, through the discouragement or outright prohibition of workers' living with their families, active recruitment of contract labour, and various restrictions on African rights for example, to engage in trade or own land in the European areas. This was the pattern at the larger enterprises, on the sisal plantations in Tanzania, on mines in the Copperbelt, and further south, in Southern Rhodesia and South Africa. 
In the case of farm labour, migrant labour was generally enforced through more indirect methods, by taxation, and the impoverishment of the African areas through over-crowding created by resettlement.

Migrant labour is, as Saul and Arrighi point out, a transient phenomenon. In the first place, with Independence, the policy of reserving the urban areas for Europeans and employing Africans as temporary guest workers, of course, had to be scrapped. In the second place, the logic of industrialization requires a literate, stable working class, at least to fill in the positions where skill, experience and acquaintance with the organisation of production are needed.

Of Tanzania, Fred Bienenfeld writes: "...the creation of a stable labour force with a real commitment to wage employment has been remarkably successful. Whether what has been created is a proletariat is a moot point. What is true is that most wage-earners are dependent on wage employment and that they represent a stable, regular workforce". 15

In Zambia there is also a clear trend towards the creation of a stable work force. Instead of "migrant labour" there is an increase in the lumpenproletariat of former peasants into the urban areas.

"The labour aristocracy thesis" reconsidered

If Saul/Arrighi were right we would expect to find an increase in the ranks of "the labour aristocracy" and a decrease in radicalization among the workers, maybe counter-acted by the radicalization among the workers, maybe counter-acted by the radicalization of the lumpen-proletariat and the peasants. An interesting recent study of Nigeria by Adrian Peace has actually induced John Saul to seriously modify his "labour aristocracy thesis". The conclusions that Peace draws are, in my view, relevant also for Zambia and Tanzania, and I therefore want to quote him at some length. Peace writes:

"In the view of the present writer, a central weakness in the ArrighiSaul formulation is the assumption that marginal increments in wages and salaries benefit workers alone when, in effect, such increments have repercussions throughout the urban arena and promote economic and political identification between the labour force and non-wage-earners. Wage-earners also express a sense of generalised social injustice not yet compunded by the development of distinct sectional interests which divide the lower strata among themselves. Therefore, should a radical movement from below emerge, social categories who have no established avenues for political protest - such as traders and the lumpen proletariat-will follow those who have. In Lagos this applies above all to the proletariat.

... the central point remains that, though the great majority of workers have broken their links with the peasantry and become wholly reliant on the industrial urban experience (for Arrighi and Saul the definitive indicators of optional proletarianisation'), their relationships with 
national elites are characterised by hostility and conflict rather than acknowledgement of congruity of essential interests.

More tellingly perhaps, if academic debate is to be made relevant to socialist goals of development, serious conceptual or empirical shortcomings in the former ill serve the political strategy by directing attention away from important areas of exploitation. To concentrate on the flow of economic surplus from the peasant economy to the urbanindustrial sector rather than explore the exploitative nature of both is, as Gavin Williams puts it, 'a classic example of the "displacement" of the "primary contradiction" between the interests of the exploiting and the exploited categories on to a "derived" contradiction between exploited classes'".16

Saul, in his self-criticism remarks:

"To be sure, Arrighi and I did not have any illusions about the longterm development potential of peripheral capitalism in contemporary Africa. However, one implication of Adrian Peace's essay is that it has even less viability in the short-term than we supposed; the bankruptcy of this option, in Nigeria at least, is already providing the objective conditions for the radicalisation of all strata of workers in his view, and in particular of the most stabilised of them. In addition, he. argues (much more explicitly) that the term 'labour aristocracy' has indeed encouraged analysts, by definition as it were, to underestimate the level of consciousness and revolutionary potential of the proletariat proper in contemporary Africa. As should by now be apparent, the seriousness of such a charge cannot be overstated!

--- we must agree that the essence of Peace's critique does stand up: the African working class should not be prematurely labelled (as appears to have been the mistake in referring to it in such an evocative term as 'labour aristocracy'). The role of this class is far from being frozen by history or by any internal logic of the current African socio-economic structure. What is needed instead is to concentrate attention upon the processes which are at work in specific African settings. This means indentifying, analytically, the objective conditions under which a more conservative or a more radical stance towards the neo-colonial situation is likely to be adopted by the working class (and further working out a prognosis for African political economies which specifies the likelihood of their providing such conditions). It also means identifying, politically, the organisational and ideological steps necessary to facilitate the emergence of those subjective conditions which are equally essential to the historical assertion of a revolutionary proletariat, and its alliance with other progressive elements, in contemporary Africa".17

Differentiations within the working population

"The laboux aristocracy" concept is based on an important insight into the actual political behaviour of part of Afrtcan labour, and an antidote against naive "labour messianism". It reminds us of the necessity to differentiate between workers and workers, but the basis for this distinction that Saul/Arrighi offered is not a satisfactory explanation. Stabilization of labour was part of the intentional, but not entirely successful, policy of the metropole capital in conjunction with the colonial administration to co-opt a small segment of the African working class while continuing to draw most of the labour for mines and plantations through the system of migrant labour. 
But neither stabilization and the ensuing severing of ties with the villages, nor the relatively advantageous economic position held by this small segment are the determinant factors for the behaviour termed "labour aristocracy". Here I think that a distinction similar to that of Poulantzas' concept of "the new petty bourgeoisie" is more helpful.

Poulantzas makes a clear distinction between the "old" petty bourgeoisie, consisting of "non-productive salaried employees". They are the ones who assume power in the post-colonial states. But they are also found among the "workers" in a broad sense of the term. They perform supervisory functions vis-à-vis the other workers, and are constantly caught between the classes, the proletariat, and the owners of capital. ${ }^{18}$ For historical reasons in the peripheral countries, this was the group that was to dominate the workers' organization, and also, later was to become integrated in the political ruling group.

The weakness of an analysis based on the concept of "the new petty bourgeoisie" is that i.t can fall into a variant of the trap of "labour messianism". Just as the stabilization of labour can be portrayed in a deterministic way to "explain" the impossibility of a formation of radical workers' consciousness, "the new petty bourgeoisie" can be treated as another way of saying that these strata can never be anything other than accomplices in a system of exploitation. This is not only an over-simplification, but also veils the highly significant fact that it is precisely from this "new petty bourgeoisie" (which includes non-workers, like teachers, clerks, government employees) that the progressive leadership is found. There is haxdly any exception to this rule.

We cannot believe that the petty-bourgeoisie ever commits suicide as a class which is possible interpretation of a famous statement by Amilcar Cabral.

Cabral claimed that if the petty-bourgeoisie taking the lead in the national-liberation movement was "an honest petty bourgeoisie", i.e. if it "remains identified with the fundamental interests of the popular masses" it may, to do this "have to commit suicide. ${ }^{19}$

There are similar statements in the texts on non-capitalist development, where at times "the new petty bourgeoisie" as a whole is treated as "revolutionary democrats".

Nevertheless, without a segment of this class evolving a nationalist anti-imperialist consciousness we would be far from a socialisoriented development emerging. The absolutely crucial question is whether and what class alliances will be formed. My hypothesis is that 
only if there is an alliance with the workers based on the workers' emerging class consciousness will there be a chance for the class struggle to be determined in favour of socialist-oriented, and against a neo-colonialist path of development.

The colonial trade unions were not instruments of formation of class consciousness, but rather tools for the manipulation of the workers through those strata of the working population, which belong to the "new petty bourgeoisie"; like clerks, foremen, etc. In those countries where the trade unions today are based on the traditions from the colonial times an analysis of organised labour today cannot be understood without looking back to the history of collective action and trade unionism. One finds very early that the class consciousness which slowly grows out of the industrial situation expresses itself in opposition against the companies, and scepticism against the co-opted trade union leaders. But before we turn to this, we will take a look at the structure of Tanzanian and Zambian underdevelopment.

The colonial legacy: dependence and limited development. At independence (1961 for Tanzania, 1964 for Zambia) both countries provided typical situations of the neo-colonial economy:

(1) Capitalism had been introduced from outside. It was not the result of an indigenous development, and consequently there was no indigenous bourgeoisie. In both Zambia and Tanzania, there was an Asian community, which occupied important positions in retail trade, housing, and transport.

(2) A high proportion of GNP went to export production; the contribution of the manufacturing sector was weak. The latter fact both illustrated the low degree of industrialisation, and the lack of an integrated development where there was, as in Zambia, a technologically advanced extractive activity.

In zambia manufacturing at Independence represented $7 \%$, in Tanzania (1965) about the same. 20

(3) The modern sector was controlled and/or owned by foreign interests, from production to trade, and banking.

(4) The majority of the population lived off the land in a stagnant subsistence agriculture. This, however, did not mean that there was "a dual economy", with two separate and unequal economies: one dynamic, modern sector, and one traditional, undeveloped, stagnant sector. Unequal they were, but not separate. The imposed Capitalist sector extracted its labour power - initially through the more or less subtle forms of taxation of all males in productive age - from the subsistence 
agriculture areas, and this was one of the primary reasons for agriculturai stagnation.

In the region to which Tanzania and Zambia belong the supply of labour from the traditional modes of production to the extractive industries in Southern Africa has induced Samir Amin to characterize it aptly as "the Africa of the labour reserves". 21

This also leads us to some of the major differences between Tanzania and Zambia (see table 1). In Zambia some of the receiving ends of this labour supply were located, notably the copper mines on the Copperbelt adjacent to the copper areas in the Southern part of the Belgian Congo (now Zaire). These were developed rapidly after 1930 by South Africanbased, British and US capital. At Independence the major part of the copper output was controlled by Oppenheimer's Anglo-American, while about twofifths was produced by Rhodesian Selection Trust, where American Metal Climax has a controlling interest (40 per cent of the shares). There was also a zinc and lead mine at Broken Hill (now Kabwe) south of the Copperbelt.

In Tanzania only the williamson diamond fields near chinyayn owned by de Beer, South Africa represented extractive industry. Capitalist penetration in Tanzania. was represented by the introduction of cash crops for export, most importantly sisal, cotton, tea, and coffee.

Coffee was grown in Tanzania on the slopes of the Kilimanjaro by African farmers of the Chagga tribe. Because of climatic conditions this was also a favoured area for mission stations in the area. As a result of this one Chagga people did have a special position as the African group favoured by Capitalist penetration, like that of the Baluba in the Congo.

In Zambia unequal development was much more pronounced as a result of the much deeper penetration emanated from the South, via South Africa and Southern Rhodesia. Along the Line of Rail, originally built as part of Cecil Rhodes' grand scheme of a British rail link as the backbone of "the Cape to Cairo" empire, European settlers opened up farmers while the African inhabitants were pushed into Reserves. Their market was the mining communities in the Congo, and later the Copperbelt.

Europeans in large numbers were also recruited to work as skilled labour and supervisors on the mines. The competition between European and African labour, which initially took forms similar to those in South Africa, is an important factor in the development of labour action in Zambia. At Independence, and even today, there are about 5,000 European employees at the Copperbelt mines. (For some figures on the number of workers in Tanzania and Zambia, see Appendix). 
Table 1. Industrial origin of the gross domestic product in

Tanzania and Zambia in percentages 1965 and 1968

\begin{tabular}{lcccc}
\hline Sector & $\begin{array}{c}1965 \\
\text { Tanzania }\end{array}$ & Zambia & $\begin{array}{c}1968 \\
\text { Tanzania }\end{array}$ & Zambia \\
\hline Agriculture, forestry, & & & & \\
and fishing & 44.6 & 10.0 & 43.2 & 8.3 \\
(Commercial farming) & $(20.7)$ & $(3.0)$ & $(19.9)$ & $?$ \\
(Other farming) & $(23.9)$ & $(7.0)$ & $(23.3)$ & $?$ \\
Mining and quarrying & 2.8 & 38.1 & 1.9 & 31.5 \\
Electricity and water & 0.9 & 1.0 & 1.0 & 1.5 \\
Manufacturing, and handicrafts & 7.7 & 7.3 & 8.6 & 9.6 \\
Construction & 3.4 & 7.2 & 4.3 & 7.9 \\
Trade & 12.3 & 13.0 & 12.8 & 14.4 \\
Finance and insurance & 10.8 & 1.9 & 9.9 & 2.4 \\
Government administration & 11.4 & 5.5 & 10.7 & 5.7 \\
Transport and communication & 6.9 & 5.9 & 8.7 & 6.0 \\
Community and business services & - & 6.2 & - & 7.7 \\
Personal service & - & 2.2 & - & 2.2 \\
& 100.8 & 100.0 & 101.1 & 100.0 \\
\hline
\end{tabular}

Sources: The Economic Survey 1973-74, Government Printer, Dar es Salaam 1975, table 5, p. 9; Ministry of Finance, Economic Report 1970, Government Printer, Lusaka 1971, p. 54.

The discrepancy between the actual sum and $100 \%$ for Tanzania is equal "imported bank service charges".

In turning now, after this brief background, to a closer look at the working class in Tanzania and Zambia, there are three questions which interest us:

(1) Can we properly speak of a working class in Tanzania and Zambia?

Who are the workers?

(2) What kinds of "workers" interests have been expressed?

(3) What is the relationship between the workers and other strata and classes, particularly the political leadership?

\section{Collective labour action before trade union formation}

The most appropriate answer to the thesis that implies that "the lower stratum" of the workers are to be counted as a progressive force only as peasants are the facts of collective labour action themselves. We have already mentioned the strikes among the African miners in the Copperbelt in 1935 and 1940, involving several thousands of workers. Of course, one can argue that they were actually striking as peasants, particularly as the target was the poll tax, levied on them in their villages. But working conditions in the mines were also attacked, and the protests were explicitly directed against the companies. 
Evidence suggests that, whether we call the workers half-peasants or not, it is precisely in their position as workers that they are capable of collective action against the exploitative mechanisms. Certainly there has been peasant opposition and budding peasant revolts, and it is probable that a careful investigation of colonial records would reveal much more of the kind than is preserved in the general history. texts. But it is also likely that peasant action often took the form of reaction and resistance. For example, there was in many cases passive resistance against the introduction of new cultivation practices (whether or not they were in the objective interest of the peasants/farmers, like irrigation and anti-erosion measures). There was also overt resistance against forced resettlement, as in the case of the removal of thousands of Tonga people from the Gwembe valley when the Kariba dam scheme in the Zambezi river was realised in 1958. But there were obvious limitations in these actions.

They did not take the form of offensive collective action threatening the system. The peasants were external obstacles to the expansion of the Capitalist mode of production, but as non-participants in the market-economy they did not constitute a force threatening that system. Indirectly, by withdrawing or refusing their labour, they did influence the making of the system. Thus, both at the South African and the Northern Rhodesian mines the companies complained that the local population were not willing to work in the mines, necessitating the elaborate system of migrant labour. Needless to say, the lack of attraction was directly caused by the bad conditions and low returns. In any case, we have no evidence of conscious collective action by the peasants on anything like the scale of the workers.

It can, of course, be argued that strikes and other forms of labour action are not necessarily signs of political radicalization. But what they do show is a capacity for collective action, and both a cause and effect of an emerging political consciousness. This is the case even if the demands remain trade unionistic, and even if no leadership emerges capable of and willing to direct this potential into political channels.

The distinction used here between "trade-union" and "political" consciousness used by Lenin in his what is to be done? By political consciousness Lenin refers to a recognition by the workers of the "the irreconcilable antagonism of their interests to the whole of the modern political and social system".

A complicating factor in the formation of working class consciousness in the colonial context must be mentioned. The owners of the 
industries and plantations were foreigners and aligned with the colonial administration, which made it more than likely that any collective consciousness would make the workers sympathetic to nationalist ideas. But there was also a racial dimension which could divert attention from the evils of the real power-holders because of the existence of a group of European employees, who themselves took action against the companies, but, above all, demanded from them protection from competition with the African workers. This took the form of various discriminatory practices, which not always were in the economic interest of the companies, who gladly would lower labour costs by letting a few Africans take over jobs at lower wages reserved by statutes or tradition for Europeans. This competition coloured labour action especially in the mines.

\section{The formation of trade unions}

A sign of the strength of collective labour action was the radical change in labour policies immediately after the second world war. Before, there had been a flat refusal to recognise any representative African labour organisation. Now, in all haste, the colonial authorities encouraged the formation of trade unions in all colonies. But significantly, the trade unions were introduced from above, and on the pattern of trade union organisation in the European metropole. 22

The story of the formation of the African Mineworkers' Union is illuminative. In 1946 a British trade union official, William Comrie, was sent out from England on an appointment to assist in the formation of trade unions "along reasonable and moderate lines". 23

Comrie assembled a few hand-picked African mine employees at Rhokana, and "in the best tradition of British trade unionism -- sought to convince African workers that the forming of a Union was their idea. and no one else's". ${ }^{24}$ The union was formed in 1948 .

It is significant that none of the "disciples of Comrie" as they were called, were in the lower work categories in the mine, and only one was associated with the underground lower groups, in his capacity as Boss Boy, i.e. the leader of a work gang. Obviously, the mineworkers' union was given to be dominated by the work categories closest to management and supervision, which in the colonial context was most affected by the job discrimination favouring the European employees.

As the trade union pattern was imported unaltered on the British pattern to suit the negotiation and arbitration practices used in England, proficiency in English was indispensable for effective leadership. Already this imperative determined the recruitment possibilities for trade union leadership. Epstein notes in his study of Luanshya that 
the internal contradictions within the African labour force came to the surface early. He summarises this development:

"The leadership of the African Mineworkers' Union was accepted because by virtue of their education, their proficiency in English, and their more obvious approximation to European standards in dress and habit, made them not only natural intermediaries between the mass of the African people and their European authorities, but they also pointed the way to a new order of society. Cleavages developed, and the very factors which brought the Union leaders into their position of power were now regarded by many Africans as an index of the distance which separates these leaders from the people".25

This cleavage was later well illustrated in the difficulties of arriving at an agreed definition of what constituted "African advancement", a popular slogan. For some, it meant the possibilities for the Africans in higher work categories to advance into positions reserved for Europeans, with their higher pay and better job security. For others, it meant general improvements of the lot of the mass of the workers. 26

In a survey in 1954 of the Roan branch of the African Mineworkers' Union, Epstein found that there was a higher percentage of union members among the well-educated, higher-paid Nyasaland members, and that there also was a correlation between length of service and union membership. This is not surprising, and is quite consistent with the "labour aristocracy thesis" or the view of "the new petty-bourgeosie" as a group that has been integrated and bought out. However, if we find internal opposition against the elite leadership, or evidence that they are responsive to pressures from below, it supports our argument that a potential radicalization exists.

In fact, the potential strength of the union, was viewed so much as a danger that after strikes in 1953-54, the companies were prepared to encourage the formation of a separate staff association for the African employees, to separate them from the majority of the workers.

In general, the companies were in a powerful position to check the development of the trade unionism "on sound lines", both through the co-operation with the colonial authorities against anything that smelled politics, by the power to influence labour legislation and bargaining practices, and by the check-off agreement. This meant that the companies agreed to automatically deduct the union fee from the miners. They also could threaten to refuse this, and put the otherwise strong financial position of the union at stake, as they did after the 1956 strikes. The authorities confidently summarised after the inception of the African Mineworkers' Union:

"There were a number of short stoppages of work during the year, most being due to a few hot-headed African workers who considered strike 
action the only way to get results. It is noticeable, however, that such stoppages have been gradually decreasing with the growth of representative organizations amongst both employers and employees. The African is realising the value of trade unions..."27

\section{Reformism strengthened by ICFTU}

There were two objectives behind the official interest in African trade unionism. One was to create a pattern for the settlement of disputes and grievances in order to halt strike actions. The other, which was furthered with the aid of international trade union organisations, was to prevent organised labour to take part in the nationalist movement and act as a political force. The latter objective was uppermost in the US-dominated International Congress of Free Trade Unions (IFCTU), created as an anti-Communist front with members among Westerns trade unions, who seceded from the World Federation of Trade Unions in 1948. Within ICFTU there was an irritation between the British trade union officials who saw a strong trade union as the guarantee for a sound social system, and the US officials and government who liked to see the ICFTU merely as an ideological weapon in the cold war.

In Zambia ICFTU had strong ties with the Mineworkers' Union, by far the most powerful union. Funds were channelled to it, advisers sent out, and union officials trained at the ICFTU trade union college in Kampala. 28

The ICFTU college in Kampala "soon played an important role for the development of trade unions in the areas from where it recruited its pupils, i.e. some fifteen countries in English-speaking Africa. This influence was reinforced by the fact that recruitment for the school's four months' courses had to be from the top layer of the organisations. only this category had the necessary combination of trade union experience and school background, to quote one Swedish principal of the college. 29

In addition to the general activities of the ICFTU there were special secretariats for certain categories of labour. The International Federation of Building Workers' had a Swedish adviser in Northern Rhodesia/Zambia, and the International Federation of Plantation workers' worked to organise plantation workers in Kenya, Tanzania, and Uganda.

Some of the weaker unions developed ties with the World Federation of Trade unions, but all through the period the trade unionist line promoted by the ICFTU through its foot-hold in the Mineworkers' Union prevailed. 
Trade unions and the nationalist movement

The efforts to keep politics and trade unionism apart seems to have been less successful in Tanzania than in Zambia. As in Guinea, there was an identification of the trade union with the nationalist campaign, and some trade union leaders "became identified in the public mind as national heroes", and later emerged as important politicians. The present Tanzanian prime minister, Rashidi Kawawa, former general secretary of the Tanganyika Federation of Labour (TEL) is a case in point. 30

Two long strikes on the railways and the sisal plantations in 1959-60 enhanced the image of the TFI, and the membership rose between 1955 and 1961 to 203,000 - twice as many as the trade union in Kenya. In 1960 Nyerere wrote in a Ghanaian journal that it was the duty of the nationalist party, Tanganyika African National Union, to help the growth of the trade unions, which, he said, was "part and parcel of the nationalist movement", and its "the industrial wing". 31 There is a belief that the trade unions played an important part in the nationalist struggle in zambia, but this does not stand up to reality. It is true that the workers, notably the mine workers, employed as they were in big concentration in a sensitive industry, were regarded as a potential threat. This was evidenced in 1956, when a series of strikes disrupting the running of the copper mines for two months, was followed by an arrest of 32 union leaders, a declaration of state of Emergency in the Western province (the Copperbelt province), and a further arrest of 31 persons, including prominent members of the African National Congress. ${ }^{32}$

It would, however, be a gross overstatement to conclude that the workers actually were a powerful, radical force in the nationalist struggle. The point is that the repression and the channelling of the potential challenge of the established economic order into toothless trade unionism actually did succeed. The failure of the alliance was glaringly evident when Katilungu, the President of the African Mineworkers' Union refused to follow a promise to call a strike in support of the ANC "days of prayer" in protest of the establishment of Federation between Northern Rhodesia, Southern Rhodesia, and Nyasaland in 1953. Despite overlapping memberships between the trade unions and the nationalist leaders a working alliance failed to appear, and friction rather than co-operation was the rule. The Branigan commission which looked into the 1956 strikes never could establish any basis for the suspicions of a political dimension of the strike movement. ${ }^{33}$

It seems as if one could explain the relatively weak identification between trade unions and the nationalist movement in zambia by the 
structural factors facilitating a manipulation of the workers' organisation by a separation of interests of the upper layers of the African workers from that of the masses. In fact, the issue of Africanisation and competition with the white unions dominated the trade union scene in Zambia. 34

This meant that the trade unions were preoccupied with opposition to racial discrimination for the relatively privileged, yet in comparison with the Europeans, deprived Africans. This was the basis for the alliance there was between the nationalist movement and the trade unions, and this might also have been the case in Tanzania.

The question of nationalisation of the foreign-owned mining companies did not become an issue in the nationalist struggle in zambia. on the contrary, as other colonies approached their day of Independence through constitutional settlements with the colonial powers, the United National Independence Party, which emerged as the leading nationalist organisation under the leadership of Kenneth Kaunda, was careful to avoid any confrontation with the companies. In 1962, a few months before the first general election, UNIP asked the mineworkers - in vain - to call off a planned strike not to uppset the Europeans and scare them into opposition to Majority rule. ${ }^{35}$ Relations were cultivated especially with the US-controlled Rhodesian Selection Trust. Its major share-holder, American Metal climax, gave scholarships to young Zambians, and when Kaunda visited the United States, he was given "a red-carpet welcome" "especially by people connected with the copper trade". 36

\section{The quest for government control of the unions}

If there was a tenuous alliance between the nationalist movement and the organised workers before Independence, conflict was almost unavoidable as soon as the nationalist movement put itself into political responsibility for an essentially unchanged colonial economy.

In this situation the new governments were forced, regardless of subjective tendencies among them, to regard the workers as producers first and foremost. If they were allies, they were so only in their role in producing exportable goods and revenue for the government. Any economic demands had to perforce be checked.

In Tanzania, there was immediately a conflict emerging between the party and the trade union over the terms and pace of Africanisation. Nyerere stated that

"It is one of the purposes of the Trade Unions to ensure for the workers a fair share of the profits of their labour. But a 'fair' share must be fair in relation to the whole society. 
--- Trade Union leaders and their followers, as long as they are socialists, will not need to be coerced by the government into keeping their demands within the limits imposed by the needs of society as a whole". 37

The right to strike was limited through legislation, and actually dwindled. But opposition continued, expressed by one part of the labour movement which refused to accept the government's call for unity. In 1964 a head-on clash seemed imminent when Nyerere announced an end to the previous policy when. "for both recruitment and promotion we gave Tanganyika citizens of African descent priority over other Tanganyika citizens". 38

Table 2 gives some indication of the structure of the working population in Tanzania and Zambia. We find that plantation agriculture is by far the most important wage sector in Tanzania, and mining in Zambia. The total number of workers is slightlyhigher in Tanzania than in Zambia (419,500 against 383,830 in 1973, non-Zambians included). But since the total population of Tanzania is two and a half times that of Zambia we find that a higher percentage of Zambians are workers. (Zambia's population is about 5 million, Tanzania's 13 million).

Statistics such as these, are however insufficient for the kind of analysis we want to make, and should therefore not be read as indicators of the development of the working class. In the first place, unemployed are not counted. In the second place, the families dependent on the wage earnings are not counted, and since we do not know what proportion of the workers are migrant workers, we do not know how many belong to the working class proper, those who are forced to live off selling their labour power, and are not part of the ideological, reproductive or supervisory apparatus. (Typical examples of these three categories are teachers, social workers, and engineers).

Nor do these statistics tell us how many of the employees belong to the "new petty-bourgeoisie". But they do give us a rough picture of the structure and the trends. An interesting finding is that there has not been any substantial increase in the number of employment opportunities in zambia. Thus not even the objective preconditions for a later key role for the workers have been developed.

The trade unions protested vehemently, and the railway workers promised to resist the policy change "at all costs". The confrontation was avoided only because the mutiny among Africans in the army came two weeks after the announcement. One of the major demand was immediate Africanisation of the army. According to W.E. Smith the trade unions were planning a general strike in alliance with the mutineers, and "there were reports of a plot at the town of Morogoro, headquarters of the plantation workers' union". 39 
Table 2. Number of employees by economic sectors in Tanzania and Zambia 1964-1973

\begin{tabular}{|c|c|c|c|c|c|c|c|c|}
\hline Sector & $\underset{\text { Tanzania }}{(\text { i })} 1964$ & $\begin{array}{r}\langle i j i\} \\
\text { Zambia }\end{array}$ & $\underset{\operatorname{Tanzania}}{(i)} 1968$ & $\begin{array}{r}(i j i) \\
\text { Zambia }\end{array}$ & $\underset{\operatorname{Tanzania}}{(\mathrm{ii})} 1972$ & $\begin{array}{c}\text { (iv) } \\
\text { Zambia }\end{array}$ & $\underset{\text { Tanzania }}{\text { (ii) }} 1973$ & $\begin{array}{c}\text { (iv) } \\
\text { Zambia }\end{array}$ \\
\hline \multirow{3}{*}{$\begin{array}{l}\text { Agricul ture } \\
\text { Mining and quarrying } \\
\text { Manufacturing } \\
\text { Construction } \\
\text { Elec tricity, water and } \\
\text { other public utilities } \\
\text { Commerce } \\
\text { Transport and } \\
\text { cormuniçations } \\
\text { Finance }\end{array}$} & $\begin{array}{r}163,589 \\
8,035 \\
23,583 \\
33,740\end{array}$ & $\begin{array}{l}34,500 \\
42,500 \\
18,000 \\
29,100\end{array}$ & $\begin{array}{r}109,213 \\
6,121 \\
35,359 \\
47,305\end{array}$ & $\begin{array}{l}34,060 \\
48,650 \\
31,540 \\
61,380\end{array}$ & $\begin{array}{r}113,843 \\
5,558 \\
55,389 \\
51,842\end{array}$ & $\begin{array}{l}34,520 \\
47,040 \\
37,490 \\
66,980\end{array}$ & $\begin{array}{c}109,047 \\
5,013 \\
59,336 \\
104,8001\end{array}$ & $\begin{array}{l}34,990 \\
51,230 \\
38,650 \\
71,630\end{array}$ \\
\hline & $\begin{array}{r}4,637 \\
17,341\end{array}$ & $\begin{array}{r}1,800 \\
14,500\end{array}$ & $\begin{array}{r}9,601 \\
21,415\end{array}$ & $\begin{array}{r}4,060 \\
25,290\end{array}$ & $\begin{array}{l}12,324 \\
24,777\end{array}$ & $\begin{array}{r}4,220 \\
33,790\end{array}$ & $\begin{array}{l}18,904 \\
26,713\end{array}$ & $\begin{array}{r}4,910 \\
31,910\end{array}$ \\
\hline & $\begin{array}{c}25,670 \\
--\end{array}$ & 8,700 & 31,764 & 20,740 & $\begin{array}{r}37,049 \\
6,356\end{array}$ & $\begin{array}{r}23,790 \\
9,980\end{array}$ & $\begin{array}{r}38,115 \\
6,515\end{array}$ & $\begin{array}{l}24,360 \\
12,400\end{array}$ \\
\hline
\end{tabular}

Sources: (i) The Economic Survey 1971-72, Government Printer, Dar es Salaam, 1972, table 29, p, 39;

(ii) Hali ya uchumi wa taifa a katika mwaka 1974-75, Dar es Salaam 1975, table 22, p, 42;

(iii) Economic Report 1970 , Government Printer, Lusaka 1971, p. 41; (iv) Monthly Digest of Statistics, Central Statistical Office, Lusaka 1975, p. 3 .

1) Including workers on the TAZARA railway. 2) Although the statistics do not comment on this, it seems probable that this category was included elsewhere before 1971 in Tanzanian and Zambian statistics.

Note (1) For Zambia 1972 and 1973 I have used the December figures. Although the categories are identical in the statistical table I think they are roughly comparable. Tanzania gives the figures for 'Estate agriculture' for the first column, for example.

Note (2) Zambian statistics differentiate between Zambians and "others", I have only included zambians here. Tanzanian statistics has no such break-down of figures.

Note (3) Table 2 gives some indication of the structure of the working population in Tanzania and Zambia. We find that plantation agriculture is by far the most important wage sector in Tanzania, and mining in Zambia. The total number of workers is lightly higher in Tanzania than in Zambia $(419,500$ against 383,830 in 1973, non-zambians included). But since the total population of Tanzania is two and a half times that of Zambia we find that a higher percentage of Zambians are workers. (Zambia's population is about 5 million, Tanzania' 13 million).

Statistics such as these, are however insufficient for the kind of analysis we want to make, and should therefore not be read as indicators of the development of the working class. In the first place, unemployed are not counted. In the second place, the families dependent on the wage earnings are not counted, and since we do not know what proportion of the workers are migrant workers, we do not know how many belong to the working class proper, those who are forced to live off selling their labour power, and are not part of the ideological, reproductive or supervisory apparatus. (Typical examples of these three categories are teachers, social workers, and engineers).

Nor does these statistics tell us how many of the employees belong to the "new petty-bourgeoisie". But they do give us a rough picture of the structure and the trends. An interesting finding is that there has not been any substantial increase in the number of employment opportunities in Zambia. Thus not even the objective preconditions for a later key role for the workers have been developed. 
The mutiny was put down with the aid of requested British assistance, and within a month the government disbanded the Tanganyika Federation of Labour, and detained a number of trade union leaders. In its stead the National Union of Tanganyika Workers (NUTA) was created. The result was thus complete government control of the trade union.

Interestingly enough the government also withdrew all Tanzanian students from the ICFTU college in Kampala.

In zambia, the government also tried to get full control of the trade unions, but it was far less successful, because of strong opposition in the Mineworkers' Union. The attempts took different forms. One was to try to get UNIP men elected to the branches of the Mineworkers' Union in 1966, which failed completely. Another was to force the Mineworkers' Union into subservience of a central organisation, the Zambia Congress of Trade Unions, but the ZCTU remained largely an educational body with little initiative of its own. Although there was some success in integrating the highest leaders of the union in the state, and in making them adopt the government view of "the national interest", the branches remained Independent, and did not discourage strike actions, which increasingly bothered the government. ${ }^{40}$

As long as the control of the economy remains fully in the hands of the foreign monopolies we have to remain sceptical of the efforts to harness the workers' organisations. Whatever the rhetoric, and however understandable the concern for higher productivity at less costs, the result in terms of development strategy cannot be anything else than the government taking responsibility for the efficient working of a neo-colonial development. The "productionist" unions act as descendants of the colonial Labour departments.

But from the late 1960's there has been a wave of nationalisations in the Third World. An important test of the question "who controls the state?" is the examination of the redefinition of the workers' role in the situation of state control of the companies.

The expansion of the state sector

The limitations of nationalisation

Certainly the reason for the nationalisations were attempts at reducing foreign dominance, and in themselves proof of a strengthening of the bargaining power of the Third World countries. Whatever the immediate effects of the take-overs, nationalisations remain a necessary, if not sufficient condition for a self-sustained economic development. Taken as whole, the nationalisation wave was a progressive phenomenon of great importance. Having said this, we have to recognise the limitations of the nationalisations: 
(1) The nationalisations were the results of considerations in the top level of the government, and not the results of demands or mobilisation among the workers themselves. The problems that the government wanted to solve were thus not so much the question of democratic control over production, as efforts to reduce the drain of resources in the forms of profits, and dividends.

(2) Even if the control of investment decisions was a significant part of the reasons behind the take-overs, nationalisations were not followed by an over-all industrialisation policy, but the economic pattern remained basically the same.

(3) For the technologically sophisticated industries nationalisation of assets did not mean the end of control, although control did not now take the form of formal ownership of the companies, but rather control of invisible assets, such as patents, licenses, and marketing arrangements to minimise losses and retain as much control as possible. The words of Sir Ronald Prain, chairman of Roan Consolidated (formerly Roan Selection Trust) can illustrate this point. In a recent book he discusses state participation in mining and claims that "the future of mining companies throughout the world depends on much closer working association with government - or not working at all". He continues: "For an established company or a group of companies in a country in which government has announced its intention to take majority holding, the best arrangement would appear to be one in which a fair settlement can be reached in the acquisition of the company's assets and a continuing interest by the company in the industry ... The "continuing interest" can range from anything from merely a retention of a proportion of the equity to contracts providing for the day-to-day management of the mines, sales, purchasing, recruiting, consultancy, exploration, and a host of other functions which can be mutually agreed".41

(4) The general pattern of nationalisation, also followed in zambia and Tanzania, was state partnership with foreign companies, who retained or (in the case of new companies entering the field) obtained minority share-holding. With management and sales contracts, and other form of "continuing interest", the actual operation of the industries was little different from the times of complete private ownership.

(5) Far from restricting the role of foreign capital the result and sometimes the explicit motive behind nationalisations was to expand the role of foreign capital. For example, the 498 take-over of the copper mines in Zambia was fore-boded in a speech by President Kaunda where he said:

"First of all, I want to say to the mining companies that I am very disappointed at the virtual lack of mining development since Independence. Apart from very small developments at Kalengwa and Mulumba Fitula and some further development at existing mines, we have seen nothing. Instead of reinvesting they have been distributing over 80 per cent of their profits and dividends". 42 
(6) The partnership arrangement meant that a new group of state bureaucrats emerged whose function is to share responsibility with the representatives of foreign capital for the running of the most important industrial activities, and who must be expected to be influenced by their "partners'" economic thinking and pattern of life.

To sum up, nationalisation, if not followed by other structural rearrangements including the re-inforcement of an alliance between the "revolutionary democrats" and the workers and peasants, is not essentially different from nationalisation and state participation in the developed Capitalist countries. There the argument is that the state has to go in where private capital is not willing to take the risks. The difference between this situation and that of the Third world countries is that private capital is less willing to take the risks in a11 sectors.

This does not mean that we can equate the state capitalism of the developed countries with that in the Third World. Tamas Szentes' words are an appropriate reminder:

"State capitalism in the underdeveloped countries differs from state monopoly capitalism in the advanced countries primarily because of its different function: instead of regulating - within some limits - the spontaneous mechanism of the already highly developed productive forces in the latter, it must rather aim at creating the conditions for the rapid growth of the hardly developed productive forces. In other words, it comes into being at a low developmental level of the productive forces. It is also the expression of the relationship of state and private capital, but this relationship is not yet determined in itself. Contrary to state capitalism in both the advanced capitalist and social--ist countries, this state capitalism may have a different and changing class content depending on the character and change in character of the state".43

The quotation above also reminds us of the fact that the expansion of the state sector does not per se signal a socialist-oriented development. When $\mathrm{V}$. Solodovnikov mentions Zambia (together with Zaire and Nigeria) as a case of capitalist development he writes that these are cases where "the state-controlled sector serves the interests of the growing bourgeoisie, and only comprises a limited number of branches or a specified sector of the economy". 44

It is, however, no longer true that the state sector in Zambia only comprises a limited number of branches or a specified sector of the economy. On the contrary, the state sector in zambia is not only among the biggest in Africa in terms of absolute production or employment figures, it also comprises all important industrial activities, and furthermore, extends into the fields of commerce and distribution, which usually are left in private hands in other countries. An important exception is banking, which still is private. This enormous 
expansion of the state sector no-withstanding, one is tempted to disagree with Kaunda and agree with Solodovnikov on the classification of Zambia's development, if not with his explanation.

\section{The nationalisations in Tanzania and Zambia}

In Tanzania the nationalisation wave started with the Arusha Declaration in 1967 and the ensuing take-over of breweries, construction firms, Insurance companies, and banking. The National Development Corporation (NDC) became the umbrella para-statal organisation under which the nationalised industries sorted. New industrial projects planned in conjuction with invited foreign firms included a fertiliser plant (with a West German company), a steel-rolling mill, a hydro-electric power station, a plant to produce paper pulp out of sisa, and rubber tyre plant. 45

In 1966 the parastatal sector in Tanzania employed 19,890 workers, and in 1971 the number (excluding workers on the Tazara railway) had risen to 63,099. Out of these more than 20,000 were engaged in manufacturing, and almost 19,000 in agriculture, compared to 3,600 and 4,700 for 1966 respectively. ${ }^{46}$

The number of parastatal enterprises rose from 47 in 1966 to 99 in 1971.47

In Zambia, state participation on a large scale started with the so-called Mulungushi reforms in 1968, when President Kaunda called on certain foreign companies in construction, transport, brewery to sell 51 per cent of theri shares to government. Twenty-six companies were affected. In August 1969 the Matero reforms followed, which meant that the copper companies followed suit. The state thus became by far the largest employer in the country. The organisational set-up was similar to that of Tanzania, only more elaborate. The para-statal umbrella organisation for manufacturing was INDECO, for mining MINDECO, for insurance and finance FINDECO, and all sorted under the zambian Industrial and Mining Corporation (ZIMCO). Mining has now been brought under the direct control of a ministry. As in the case of NDC in Tanzania, these para-statal bodies were fairly autonomous from government control, and worked by the principle of profit maximising for each separate enterprise concerned.

An idea of the proportions between Zambia and Tanzania can be given in the following figures: Even before the economic reforms, the assets of INDECO were as large as those of the NDC after the Arusha reforms. By 1973 they were about six times the size of Tanzania's. In 1968 the net assets had been about 35,5 million Kwacha, by 1972 the figure had 
multiplied six times, to 233 million Kwacha. And this, it must be remembered, does not include mining. In 1973 the productive divisions of INDECO employed about $45 \%$ of all manufacturing workers. ${ }^{48}$

Nationalisations and wage control

Apart from extending state control over the operation of the companies nationalisation also made possible tighter state control of wage policies. In Tanzania, the government declared in 1967:

"... There is a change in the role of trade unionism brought about by the new policy of Socialism based on Self-Reliance. Under a colonial administration, even for as long as a system of unrestricted capitalism and private enterprise survived under an independent Government, the labour movement was justified in making profits the basis for higher wage claims. But Socialism now means centralised planning for economic and social development with resulting benefits spread equally throughout all sectors of the community: it does not mean freedom for the trade union movement, or any other organisation or institution, to pursue group or sectional interests to the possible detriment of others". 49

If we compare with the quotation on page 214 we see that little has changed, except that government control strengthens the argument of "the national interest".

In Zambia, President Kaunda warned that workers who now demand higher salaries from the companies "push a wage claim against the people". ${ }^{50}$ He also declared that nationalisation was, the definite end to the formation of a working class in Zambia:

"... class consciousness is one of the biggest dangers in Zambia. Workers can themselves be a source of force in the creation of classes. By trying to group themselves together and distinguish theinselves from the rest of society in pursuit of what they may believe to be their own interests as workers they provoke response from the rest of their fellowmen ... For Zambia, it is ridiculous for workers now in the light of these reforms to feel that they are a distinct class". 51

In July 1968, a Government white Paper in Tanzania outlined a wages policy limiting to $5 \%$ the total cost of national wage increases. In order to remove the disparities in the distribution of incomes lower paid workers were expected to receive more than the prescribed $5 \%$ increase, salaried workers less. There does not seem to be the same conscious wage policy of equalizing wage levels in Zambia, but rather a primitive contraposition of workers against peasants, without any nuances or differentiations. In 1969 Kaunda declared: "I should remind you that we, the workers, we the urbanites, have had it very good since Independence at the expense of our own brothers and sisters, the peasants, in the countryside". 52

At the same time, little is done even to equalize the enormous wage differences among the workers on the mines, which the government chooses 
to see as privileged lot that has to be taught the ethic of selfrestraint. In 1973, in interviews with mine workers, I could record wages among African underground workers up to 800-900 Kwacha a month, while general workers on the surface were employed at 1 Kwacha a day! The policy of wage restraint is made all the more difficult to be accepted by the miners because of the continued discrimination in favour of the European employees, who are paid 4-5 times more than the highest-paid African miners. In fact, in recent years extra tax benefits have been bestowed upon them to prevent an out-flow of engineering and management personnel.

\section{Workers' participation}

If nationalisation has meant the harnessing of trade unionist tendencies of the trade unions, what about the encouragement of a political consciousness and actual participation in the running of the economy? Nationalisation has meant a closer integration of the workers organisations in the state apparatus, but has it also meant a closer political alliance between workers and other strata, and particularly the ruling group? Evidence suggest that the answer is negative. What seems to have emerged is an increase in the political consciousness of the workers, and a perception of their interests as opposed to and blocked by the "administrative bourgeoisie" itself.

\section{Zambia}

In Zambia this has been documented by research conducted by Michael Burawoy, who in 1971 found dissatisfaction with trade union, and a feeling among many workers that Africanisation has created a zambian elite, which can exploit him all the more effectively because they also possess political power. Some examples:

\footnotetext{
"The management is good but the black people who have taken over from expatriates are very bad. Once they have been given a big house in town they are happy and forget about the workers". 53
}

"Nationlisation has not made any difference. In fact the work has become harder than we expected.

"I do not know what is happening with our Government. During the colonial days we were getting a copper bonus and now this has been abolished and the mining companies say that it has absorbed the bonus into our salaries but we see no difference in our salaries. --- All the unionists are Government supporters and I suspect that the mine management gives them money to cover up its evils in dealing with our genuine complaints".54

I could note a similar cynicism about the nationalisations in 1973, when an underground worker simply brushed the question of nationalisation aside by saying: "Nationalisation has nothing to do with us, it is something for them on the top". 
In an interview in 1972 Kaunda described the takeover of industries and mines as only a step towards people's power:

"In the main, what we have been doing is really to create state capitalism, but that is a transition. We should be aiming at introducing industrial participatory democracy... our economic objectives should be to introduce industrial participatory democracy so that all round, people contract the power, whether this be political, economic, social or cultural. Indeed, even scientific and technological".55

But in reality, nothing has happened. Instead, a highly centralized system for the regulation of disputes, including an Industrial court, has been instituted. The Industrial Relations Act of 1971 provides for the formation of workers' committees "designed to give the workers more say in the decision-making where they work", but this is the only provision of the act that has not yet been implemented. 56

Appeals to the mineworkers to think of their sisters and brothers in the countryside are likely to be greeted with scepticism, coming as they do from an increasingly well-entrenched elite group, or as the popular saying goes, "the Wabenzi people" (those who travel in Mercedes Benz). Also, "the mineworkers have not seen any significant rural development (except the expansion of the educational system) or any aramatic improvements in the welfare of their kinsmen in the villages or even in the towns". 57

If anything the workers have been alienated from the ruling group. Zambian news-papers have reported a general lack of interest in joining the party among the copper mines. The situation hardly improved when, in the beginning of 1976 , price control of maize was lifted.

\section{Workers' participation: Tanzania}

In Tanzania, too, nationalisation has meant tighter government control over unions. But there are significant differences both in the organisational efforts to embrace the workers in the political development, and in the attitude of the national leaders, or part of them, to signs of increasing political consciousness among the workers.

In a presidential circular 1970 it was stated that every firm or Public corporation with more than ten workers should establish a Workers' Council. Even before, there had been vigourous attempts to create branches of the party at each enterprise. Workers' committees, which are the lowest level of the trade unions, were established since 1964 as consultative organs concerned with the welfare of the workers. It is doubtful whether the not-yet established workers' committees in zambia would amount to anything more than this.

But even the Workers' Councils had their serious limitations. As 
Henry Mapolu points out, in Marxist theory, workers' management is seen "within the context of the total organisation of society", whereas Tanzania's socialism is "more a set of pragmatic propositions for solving a limited number of contemporary issues". Thus, management has been given a dominant role in the workers' councils based on the belief that management and workers have coinciding interests. 58

But the role of management soon came under attack from the workers. The signal to a wave of protests came after the Party Guidelines, the Mwongozo, had been announced by the party leadership in 1971, and brought to everybody's attention through a mass campaign. This document talked about Tanzanian development as a liberation struggle and spoke for a new view of the role of workers. In clause 15 it said that "for a Tanzanian leader it must be forbidden to be arrogant, extravagant, contemptuous and oppressive". This spated off a wave of strikes against management bearing exactly those characteristics. According to a figure computed by Mapolu, in nine months more than 45,000 man-days were lost through strikes about arrogant and oppressive management. 59

This was followed by some allegations of irresponsibility, and "abuse" of clause 15 in the Mwongozo. But significantly, a clear division appeared among the ruling group, with President Nyerere taking the side of those who saw both the Mwongozo themselves, and their consequences for labour relations as a positive development. In November 1971 he said that

"it was noteworthy that in the various strikes, workers were not demanding wage increases but protesting against the alleged unbecoming behaviour of certain people in the management and administration echelons. This is a clear indication that the workers understand the Guidelines very well..."60

The trade union itself, NUTA, did not show any willingness to take a lead in the implementation of the Guidelines, and their officials were often shouted down. Here we see a similar development as in zambia, where the leadership of the trade union becomes part and parcel of the ruling group, and falls within its most conservative factions. We also see a growing awareness among the workers themselves that the problems are those of actual share and control in decision-making, and that some Africans, among their leaders and managers, belong to the obstacles. 61

\section{Conclusion}

Neither in Zambia nor in Tanzania have we seen a development of an active alliance between "the revolutionary democrats" and the workers and peasants dominating the scene. In both countries the labour organisations have been integrated into the state machinery, and are general$l_{y}$ used to raise productivity, restrain wage demands, and prevent strike action. 
The change in the function of the trade unions from "voluntarist" to "productionist", as William H. Friedland has coined it, 62 is a general phenomenon in all of independent Africa. In itself it says nothing about the social content of the policies. Restraint of wage demands are both expected in reactionary regimes where the power-holders berich themselves at the expense of the masses, and are expected and justified in countries where a progressive regime wants all efforts concentrated on raising productivity for equalised distribution of the goods and services, or in crisis situations, where an immediate enemy must be contested (as during the second war of liberation in Angola 1975).

If the above features do not say anything about the social content of the development policies, we can still say that, if these features exhaustingly characterise the relationship between the workers and the ruling group, there are no political forms emerging necessary for socialist-oriented development. In other words, it is possible to have a progressive social content in a country without a progressive political development. Where this is the case, the struggle between reactionary (neo-colonial tendencies and progressive) socialist-oriented is likely to be present on all planes. But as long as the political forms are not changed to effect an active alliance between the progressive elements within the petty-bourgeoisie, and the productive workers and peasants, (as distinct from the non-productive layer of the working population, who themselves belong to the vacillating petty-bourgeoisie), we have no reason to herald the victory of noncapitalist development towards socialism.

The contradictions between progressives (anti-imperialists) and conservatives (neo-colonial strata) in Tanzania, here only illustrated by the example of the strike movement after 1971, indicate that the struggle for socialist-oriented development is continuing. In zambia we have not been able to document such contradictions, instead there are demands from powerful sectors within the ruling group to abandon the few remaining progressive principles in foreign policy (such as the continued closure of the border with Rhodesia). The guiding principle is repression, not persuasion of mobilisation. 63

The difference between Tanzania and Zambia is not simply that between the personalities of Nyerere and Kaunda. Zambia has a proportionally much larger working class, (see appendix) but has evolved as a whole, repressive labour policies, whereas the development in Tanzania is more open to interpretation. From the comparison between the two countries, one could advance a hypothesis quite contradictory to the deterministic views of the role of the working class in socialist oriented development. 
It would seem that the existence of a large working class is a signal of much greater tendencies for state capitalism to develop into capitalist lines. Because the existence of a large working class is also a sign of the deeper penetration of foreign capital, and of greater temptations for the ruling group to serve as junior partners, and live off the shares of a neo-colonial development leaving the majority of the population in essentially the same, or even worse, conditions as before Independence. It follows from this hypothesis that the pre-condition of a socialist-oriented development in a peripheral society with a relatively large working class, is an open confrontation between the different tendencies within the ruling pettybourgeoisie and its respective allies.

\section{NOTES}

1. Gleb Starushenko, Africa Makes a Choice, Novosti Press Agency Publishing House, Moscow 1975, p. 26 .

2. For example, in $\mathrm{V}$. Solodovnikov and $\mathrm{V}$. Bogoslovsky, Non-Capitalist Development, An Historical Outline, Progress Publishers, Moscow, 1975, it is said that "non-capitalist development is, above all, the way towards creating the material prerequisites for the building of a socialist society".

3. A. Iskenderov, Africa, Politics, Economy Ideology, Progress Publishers, Mos Cow 1972 .

4. Hans Kramer, "Welchen Entwicklungsweg geht die Republik Sambia?" in Nichtkapitalistische Entwicklungsweg, ed. Ruth Alexendel, Berin 1973, p. 362 .

5. Starushenko, op. cit., p. 6 .

6. I will use the names "Tanzania" and "Zambia" all through the text, instead of differing between the period when mainland Tanzania was "Tanganyika" before the inclusion of Zansibar, and the colonial period of Zambia, which was called Northern Rhodesia.

7. Nichtkapitalistischer Entwicklungsweg, ed., Ruth Andexel, AkademieVerlag Berlin 1972, Lothar Rathmann and Hartmut Schilling,

"Probleme des nichtkapitalistischen Weges der Volker Asiens und Afrikas in der gegenwärtigen Etappe der nationalen Befreiungsbewegung", p. 8 .

8. V. Afanasyev, M. Makarova, L. Minayev, Fundamentals of Scientific Socialism, Progress Publishers, Moscow 1969, p. 139.

9. Quoted in op. cit., p. 131 .

10. A. L. Epstein, Politics in an Urban Community, Manchester University Press, Manchester 1958, p. 6.

11. Ibid., p. 8 .

12. Ibid., p. 236

13. Ibid. , p. 232 
14. Giovanni Arrighi and John Saul, "Socialism and Economic Development in Tropical Africa", in Arrighi \& Saul, Essays on the Political Economy of Africa, Monthly Review Press, New York 1973, p. 69.

15. "Socialist Development and the Workers in Tanzania", in Richard Sandbrook and Robin Cohen ed. , The Development of an African

Working Class, Longman $197 \overline{5}$, p. 255 .

16. Adrian Peace, "The Lagos Proletariat: Labour Aristocrats or Populist Militants?", in Richard Sandbrook and Robin Cohen, eds., The Development of an African Working Class, Longman, London 1975, $299-300$.

17. John Saul, "The Labour Aristocracy Thesis Reconsidered", in ibid., p. 306 .

18. Nicos Poulantzas, Classes in Contemporary Capitalism: NuB Books, London 1975, pp. $1 \overline{93-336 .}$

19. Amilcar Cabral, Revolution in Guinea, Stage Books, London 1969, p. 59 .

20. Seidman, "The need for a long-term industrial strategy in Zambia", in Seidman, ed. Natural Resources and National Welfare; the case of copper, Praeger, New York 1975, p. 360; The Economic Survey 1973-74, Government Printer, Tanzania 1975, table 4 .

21. Samir Amin in Journal of Peace Research, No. 2, 1972.

22. See Joan Davies, African Trade Unions, ch. 5, Penguin African Library, Hammondsworth 1966 .

23. W.R. Jacobs, The Relationship between the nationalist movement and the trade union in the Coppervelt 1949-1961, Int. Institute for Labour Studies, Geneva 1971, p. 21 .

24. S. Zelniker, Changing Patterns of Trade Unionism: The Zambian case 1948-1964, University of California Ph.D. 1970, University Microfilms, p. 126 .

25. Epstein, Ibid., p. XVI.

26. See Epstein, op. cit., and Elena L. Berger, Labour, Race, and Colonial Rule; the Copperbelt from 1924 to Independence, Oxford University Press, Oxford 1974 .

27. The Annual Report of the Labour and Mines Department, Lusaka 1949, p. 15 .

28. Bates, op. cit., pp. 131-132.

29. Sven Fockstedt, Afrikansk fackföreningsrörelse, Afrikainstitutets skriftserie, Stockholm 1964 .

30. Davies, op. cit., p. 110 .

31. Ibid., pp. 110-111.

32. Berger, op. cit., p. 152 .

33. Berger, p. 154 .

34. For a detailed account of this, see Berger, op. cit. 
35. Robert H. Bates, Unions, Parties, and Political Development; $A$ Study of Mineworkers in Zambia, Yale University Press, New Haven 1971, pp. 133-136.

36. Richard Hall, Kaunda, Founder of Zambia, Lusaka 1964, p. 32.

37. Julius K. Nyerere, "Ujamaa: the Basis of African Socialism", in Freedom and Unity, Oxford University Press, DSM 1966, p. 169.

38. Nyerere, "Tanganyika Citizenship", in Freedom and Unity, p. 259.

39. W.E. Smith, Nyerere of Tanzania, Gollancz 1973. See also Davies, op. cit., pp. 16I-164.

40. See Bates, ibid.; Anirudha Gupta, "Trade Unionism and politics on the Copperbelt", in William Tordoff, ed., Politics in Zambia, Manchester University Press 1974.

41. Sir Ronald Prain, Copper, the Anatomy of an Industry, Mining Journal Books, London 1975, p. 242.

42. Kenneth Kaunda, Zambia Towards Economic Independence, Government Printer, Lusaka 1968, pp. 45-46.

43. Tomas Szentes, "'Status quo' and Socialism", in Issa Shivji inter alia, Tanzania, The Silent Class Struggle, Zenit Reprint, Lund $\overline{1971}$, p. 76 .

"State capitalism", according to szentes, "under whatever conditions it may come to life, is nothing else but the restriction and regulation, by the state, of economic spontaneity stemming from the existence of private capital". (Ibid,. p. 75)

44. V.G. Solodovnikov, "Vejen till Socialisme gennem ikkekapitalistisk udvikkling", Den ny verden nr 4, 1975.

45. Ann Seidman, "Tanzania's Industrial Strategy", in Lionel cliffe and John Saul, ed., Socialism in Tanzania, Vol. 2, East African Publishing House, Nairobi 1973, p. 97).

46. Analysis of Accounts of Parastatals 1966-1971, Bureau of Statistics, Dar es Salaam 1972, table 2. The figures for 1971 are provisional.

47. Ibid., p. 1 .

48. Seidman, "The Need for an Industrial strategy in Zambia", in Seidman, ed., Natural Resources and National Welfare, The Case of Copper, Praeger, New York 1975, p. 369 .

49. "Proposals of the Tanzania Government on the Recommendations of the Presidential Commission of Enquiry into the National Union of Tanganyika Workers, Government Paper 2 of 1967, Government Printer Dar es Salaam 1967, p. 81.

50. Zambia Mail, April 3, 1970.

51. Kenneth Kaunda, Towards Complete Independence, pp. 45-46) .

52. Kaunda, Report of the Second National Convention on Rural Development, Incomes, wages and prices in Zambia, Dec. 12-16, 1969.

53. Michael Burawoy, The Colour of Class on the Copper Mines, University of Zambia, Institute for African Studies, Zambian Papers No. 7, Lusaka 1972, p. 75). 
54. Ibid., p. 80-81.

55. Interview with President Kaunda in Indeco's journal Enterprise, 4 th quarter 1972 , p. 2-3.

56. Times of Zambia, Jan. 6, 1975.

57. Burawoy, "Another look at the mine-worker", African Social Research, Lusaka, December 1972, p. 252.

58. Henry Mapoly, The Organisation and Participation of Workers in Tanzania, Economic Research Bureau Paper 1, 1972, Dar es Salaam, pp. 22-23.

59. Mapolu, "Labour unrest: irresponsibility or workers' revolution", Jenga 12, 1972, pp. 20-23.

60. The Nationalist, November 18,1971 .

61. Manfred Bienenfeld, "Socialist Development and the Workers in Tanzania", in Sandbrook \& Cohen, op.cit., p. 253.

62. William H. Friedland, "Basic Social Trends", in Friedman \& Rosberg, eds., African Socialism, Stanford University Press 1964, pp. 19-21.

63. In January 1976, President Kaunda declared a state of Emergency and some teachers and students who had criticized zambia's support for UNITA in Angola were arrested without charges. The Copperbelt area introduced a curfew and restrictions on the freedom of movement. 
REPORTS FROM THE WORKING GROUPS AT THE SEMINAR ON NON-CAPITALIST

DEVELOPMENT IN AFRICA, AUGUST 16-19, 1976 IN HELSINKI, FINLAND

\author{
Report from working group I
}

Is political mobilization a sine gua non for non-capitalist development? Peasants, workers and petty bourgeoisie - alliance or confrontation?

Chairmen/rapporteurs: A.M.M. Ashur, Somali Democratic Republic, Mai Palmberg, Sweden. Participants: Mohamed Aden, Luigi Pestalozza, Jürg Mahner, Jack Woddis, Mouna Diallo, Jeremy Gould, Pertti Multanen, Riitta Launonen, Olli Salin, J. Koponen, Lars Rudebeck, Sirkka Jauho, Erkki Laurila.

The problems/questions touched upon were:

(1) The nature of the relationship between the state, the party, on the one hand, and the workers' organisation/the trade unions on the other hand.

Examples cited from Somalia, Guinea-Bissau, Angola, Tanzania, Zambia, Congo-Brazzaville.

(2) The sociomeconomic structure and the existence of and need for strong workers' organizations. Congo-B and Angola cited as exceptions to the rule that the African-countries are agricultural countries dominated in the social composition by the peasants.

(3) Differentiations within the agricultural population - what effects it might have on mobilization efforts, credit institutions etc.

(4) The different party types: cadre parties of a Bolshevik type, for example, Congo-B, or mass parties, for example, Guinea-Bissau. Risks in both: exclusiveness in the first type, personal utilization, and corruption for some in the second.

(5) Mobilization for what? A distinction was made between mobilization for economic accumulation, and political conscientization.

(6) On the question of mobilization for economic accumulation a point was made that material improvements might not at all be possible in the foreseable future for the large majority of peasants; sacrifices had to be asked from them, through political education. This was disputed by reference to Amilcar Cabral's insistence on the immediate improvement of the conditions for peasants as the only way to mobilize them. There was no agreement on this, but the answer might lie in the recognition of a wider definition of "material improvements" than usually employed, for example, the social improvements, like access to water and some security in case of bad harvests and a genuine say in the decisionmaking on the local level. These goals seem not only possible, but necessary.

(7) Somalia was given as a concrete example of an experience of an unusual kind in Africa: national unity in the foreground, early attained, a distinctive patriotic tradition in the army ranks, the occurrence of a natural disaster, the famine, as a starting point for a significant reorganisation of the socio-economic structure. The discussion on the alternative to a nomad society was discussed.

(8) Cliffe's differentiation between mobilization for the defence of progressive regimes, and mobilization as part of a national development plan gives an analytical tool, close to the distinction in point 5 . 
(9) The concept of "alliance" was discussed, and it was agreed that in very few, if any, African countries do we have the case of an alliance in the usual sense of the concept: a coming together of different groups for a minimum platform of immediate tasks. Instead, there is a more philosophical alliance, expressed within the one-party-system, often even by groups and strata representing the interests of the broad broader masses, but not elected by them, nor having necessarily peasant or worker origin. The question naturally comes in about the truth in the claims of representation, which can only be assessed through looking at the concrete policies, and participation arrangements. The orientation centres in somalia was cited as an example of such a focus.

(10) What is the role of the "revolutionary democrats" and their relationship to the working masses? Can they decide for the broader masses? Can the decisions and formulations of mobilization be made by them, and then brought to the people?

(1.) We also touched upon the important question of categorization of the "progressive" states. The question was raised whether the differences between, say, Kenya and Tanzania were more important than the similarities. The differences lie in politic organization and manifested goals, not in socio-economic structure, neither in the reliance on foreign aid and capital. The danger of demobilization through a state partnership with foreign companies was pointed out. At the same time it was stressed that it is easier in the future to nationalize plants that produce within the country than plants which are in the developed capitalist countries.

(12) The concept of "labour aristocracy" was discussed during the first session, and the validity of the concept was disputed. Comparisons were made with workers in developed countries, who also display differentiations, and where usually the highest paid workers were the most militant ones. But is was also pointed out that the concept could be used in special cases, as long as it does not imply a natural inclination on the part of all workers in Africa to be supporters of a neo-colonialist path and elite. The relevance and existence of a class struggle within the workers' organizations was pointed out.

Report from working group II

What is the place of foreign capital and assistance in socialist orientation? The connections between the new economic order and socialist orientation.

Chairmen/rapporteurs: Guy Arnold, England, Jan Otto Andersson, Finland, Participants: Timothy Shaw, Arild Vollan, Jens Erik Torp, Amine Kherbi, Ragnar Feiring, Haregu Kahsai, Bertil Odén, Lennart Wohlgemuth, M. R. Bhagavan, Atle Hetland, Peter Mandi.

As the result of a wide ranging preliminary discussion the group decided to deal with the subject under three main headings:

(1) Self-reliance

(2) The New International Economic order

(3) The relevance of the experiences of the countries developing along non-capitalist lines to the rest

The subject was so wide that, in fact, large areas were not dealt with at all. Although agreed about aims the group was often uncertain of the particular means that should be applied in any one case. 


\section{Self-reliance}

Taking the statement - 'The key to capitalist control in Africa is the attractive external link between the ruling elites and outside capitalist connections' - the question was considered: How can this be broken?

Discussion ranged from the possibility of total breaks with the capitalist world to the position of a general acceptance that links have to continue and, therefore, a consideration of how they should be controlled.

It was always important to bear in mind the fact that countries which seek self-reliance are underdeveloped and a part of the capitalist system.

It was considered that a pre-requisite of self-reliance was selfconfidence and that this would depend upon two things:

(1) Internal factors - that is, the stage of economic and political development reached; and

(2) External factors - that is, the degree of dependence upon outside countries, assistance etc.

For self-reliance to succeed a relatively high degree of self-sufficiency is needed and in this respect two contrary examples were examined:

(1) Algeria. It was agreed that she was approaching self-reliance but that she had to import very expensive technology.

(2) Congo (B). It was felt that if she attempted to follow a course of self-reliance now by, for example, a programme of nationalisation of foreign assets she might well destroy the possibility of achieving true self-reliance at a later date.

The group felt that the pre-conditions for self-reliance simply did not exist in many countries in Africa.

Self-reliance was regarded as a means of promoting a trend against the capitalist system and collective self-reliance - if it could be achieved - as a means of achieving the objective of the destruction of the capitalist system. However, self-reliance was regarded as a line of policy rather than as an end in itself. It is a question of mobilising manpower and resources. It represents a choice of the opposite path to that of those countries which turn first to foreign aid and capital assistance.

It is essential that a country which aims a self-reliance should take control of its resources.

It was emphasised that self-reliance should not be confused with autarky: no country can exist in a vacuum; all must have relations with other such as trade. In considering the question of the new economic order, for example, it was felt that a key to any success by the Third World would depend upon the degree of collective self-reliance that had first been achieved.

\section{$\underline{\text { Aid }}$}

On the question of aid it was felt that under certain conditions countries following the non-capitalist path could nonetheless accept aid that would produce advances in their development if three criteria were met:

(1) The goals of the recipient and the aid agency coincided;

(2) There were no strings attached to the aid;

(3) There was a capacity (on the part of the recipient) to use aid with strings and yet not be tied. 
In terms of the present stage of economic relations and development of African countries the group advanced a number of quertes:

(1) That in most cases self-rellance would not be possible without help from the socialist countries.

(2) That the pursuit of self-reliance could imply a contradiction with socialist countries.

(3) That the developing countries alone would be unable to break from capitalist control.

(4) That in realistic terms non-capitalist development in Africa has to be related to the existing power structures in the world.

(5) That, for example, the new relations between East and West - détente must be taken into account.

(6) The isolation of those countries in Africa which have pursued a non-capitalist approach to development was noted.

In conclusion (in relation to the idea of the attainment of selfreliance) it was felt that changes will occur but only in the light of two considerations:

(1) The powerful inducements that are constantly offered by the capitalist countries.

(2) The limitations that affect the role of the socialist countries in two respects:

i) i) Their relative poverty when compared with the capitalist countries;

ii) The fact that for historical reasons the African economies are overwhelmingly capitalist oriented.

Yet at the same time the recent example of Angola was cited as an example of the effects of the introduction of the external factor which In this case has not only affected the direction of development in Angola 1tself but also of the whole region of southern Africa.

The new international economic order

A series of question were first posed as follows:

(1) What are the conditions that have given rise to demands for a New Economic Order?

(2) What character will the New Economic order take?

(3) Is it to be revolution or reform?

(4) What impact will the New Economic Order have on the dependent countries?

(5) In whose interests is the New Economic Order: of the capitalist countries? the socialist countries?

(6) If it is not, what will they do in reaction to attempts to introduce it?

(7) Is the search for self-reliance compatible with the New Economic Order?

(8) Will Third World unity be maintained?

The point was made, for example, that the economic relationship of African countries to the USSR - supplying raw materials and taking manufactured goods in return - is very similar to their relationship with capitalist countries and the question was asked: whether this relationship is also to be changed. 
The demand for a New Economic Order is directed by a reaction to capitalism. The question arose as to what the masses can expect to obtain from the New Economic Order.

It was considered that even if only some aspects of the programme for a New Economic order could be implemented this would enable new directions to be taken.

The present programme for the New Economic Order is based upon the strategy of:

(1) Questioning the capitalist structure that controls raw materials.

(2) Attempting to transform world trade patterns.

At present it appears clear that the New Economic order will not destroy the capitalist system yet every small gain in the quest for the New Economic order represents a step forward. In the end, however, only internal revolutions can destroy capitalism.

In considering whether the New Economic order could change anything it was felt that:

(1) There should be no confrontation since the Third World countries are too weak.

(2) That the chances of change in any case are slight.

(3) That the power of the capitalist system to corrupt is great.

(4) That divisions within the Third World must be taken into account.

(5) And therefore that for the New Economic order to have a chance two things are required:

i) That the progressive forces in the capitalist world fight for it.

ii) That a special effort is forthcoming from the socialist countries to help bring about the New Economic order.

In conclusion two points were emphasised:

(1) The great adaptability of capitalism although the capitalist countries now appear to be facing increasing internal problems of their own.

(2) That there is great need for more positive assistance in establishing the New Economic Order from the socialist countries.

The relevance of the experiences of the countries following

a non-capitalist path of development

There was great difficulty in relating the particular experiences of one country at a particular phase in its development to the position of another country where conditions and the stage of development are both different.

It also proved difficult to find common factors that would provide simple guidelines for a country attempting to change its approach to development.

The debt problem was cited as a key example of one of the means used to prevent any action against the prevailing interests of the capitalist countries.

One positive example was cited of a country that had chosen the non-capitalist path of development learning from the experience of another. Following its liberation Guinea-Bissau decided not to attempt to develop its bauxite deposits for ten years. It did so as a result of its leadership having witnessed the problems encountered by Guinea (Conakry) in developing its own minerals; the leadership in GuineaBissau felt that it would simply not be in command of the expertise for such development before ten years had passed and did not wish to see control of the bauxite resources pass into foreign hands. 
Generally, however, the group could not establish any rule to guide countries wishing to break from capitalist control.

It did feel that present conditions in Africa are now ripe for changes to be introduced.

On the whole it was felt that it is difficult to transpose the experiences of one country to another though there are common factors at work.

\section{Conclusions}

In a negative sense it was felt that the difficulty lay in finding the correct way for a particular country at a particular time to change from being a part of the capitalist system to pursuing a non-capitalist path of development.

Positively the group agreed that:

(1) The present time is ripe for change.

(2) The countries of Africa need help in achieving such change - that is, there is a place for the external factor.

(3) A particular responsibility to provide such help devolves upon the socialist countries.

Report from working group III

Is there a non-capitalist industrialisation strategy? What is a non-capitalist state sector?

Chairmen/rapporteurs: Archie Mafeje, Holland, M.R. Bhagavan, Sweden. Participants: John Ohiorhenuan, Britha Mikkelsen, Lena Svanberg, Gören Hallströ̀m, Emanuel Hethe, Tore Linné Eriksen, Björn Beckman.

This group was a merger of two; one, asked to consider the question "is there a non-capitalist industrialisation strategy?"; the other, "what is a non-capitalist state sector?" The group combined the two themes by focusing on the state manufacturing sector. The Tanzanian case was used as a point of departure and most of the discussion was related to this concrete experience, with occasional reference to others, Kenya in particular. Studies by M.R. Bhagavan and associates (two of them submitted as papers to the conference) served as our principal base material. other members of the group could draw on considerable experience of Tanzania (T) as students, teachers and even as administrators. The discussion was organised around the following issues derived mainly from an introductory statement by M.R. Bhagavan:

(1) State control of investment capital

(2) State control of management

(3) Questions of hierarchy and workers' participation and control

(4) Forms and direction of surplus appropriation

(5) The direction of production: the structure of output

(6) Questions of technological choice

Most of our attention was devoted to points 1 and 3 and this report will deal mainly with those two with some scattered references to the others. The argument raised in the group concerned primarily the nature 
of the $T$ system. We also ventured certain explanations of its main characteristics. We only touched on questions of alternative strategies.

At first major question concerned the significance to be attributed to the structure of ownership in the parastatal sector, which dominates the $T$ manufacturing industry. It was noted that apart from the large direct foreign investment, the share of the state in ownership is almost completely financed from outside as well. It was agreed in the group that this heavy dependence affected the prospects of socialist oriented development negatively. It was also agreed that a higher level of domestic accumulation was vital in order to broaden political options.

Views differed on the prospects of reducing dependence on MNC management and technological choices through such increased domestic control of capital. A distinction was made, however, in that context between such dependence which implies the outflow of surplus value (imperialist dependence) and dependence arising from the need to buy technology and managerial skills from abrod. There were diverging views on the structure of the international market in such items and its relative "freedom". The way that freedom of choice is assessed is likely to affect the relative importance attributed to the "liberating " role of domestic financing of state investment. There was, however, a more fundamental disagreement over the scope for eliminating the participation of foreign capital in the state industrial sector. It was held on one hand, that shortage of capital is a fundamental characteristics of underdevelopment and that capital imports are therefore part of the logic of overcoming underdevelopment. On the other hand, the scope for local accumulation was considered to be substantial.

The case against foreign capital was twofold. Firstly, its positive contribution to the growth of production was negated by the outflow of surplus. Secondly, foreign capital was considered to have a fundamental negative impact on class formation, providing a basis for an alliance between MNCs and a local ruling group, composed of the top management of the parastatals and the top government bureaucrats. No one in the group denied the existence of such an "alliance" and its negative implications for a socialist oriented development, (the outflow of surplus, the bolstering of a parasitic class etc,), but there was a major disagreement over how fundamental this should be considered to be in defining the class character of the $T$ state in general, and in ruling out a socialist orientation in particular.

on one hand, it was maintained that the alliance played a crucial role in the transformation of this local ruling stratum into a bureaucratic-managerial ruling class and in sharpening the antagonistic contradiction between the state and the working class.

Opposed to this was the view that neither managers or top bureaucrats could be treated as a ruling class (not even in formation) because they were unable to reproduce themselves as a class but were rather recruited into their positions by virtue of training and other arrangements. They ought, therefore, according to this view, be treated as members of a broader petty-bourgeois stratum with a vaccilating position between the main classes and thus not locked into a fundamental contradiction with the working class, except in their normal position as upholders of state power. A shift within this stratum in favour of socialist orientation was therefore not considered precluded by its "alliance" with the MNCs. Attempts were made by others in the group to combine the two lines of argument by stressing the internal contradictions of this ruling stratum and the crucial role of domestic alliances in affecting the nature of political options.

As far as the Tanzanian industrial working class is concerned it was generally accepted that it is essentially sedentary (non-migratory) although different weight was attributed to the continued existence of a "peasant-option", that is, an option opened by the absence of such land shortage in the agrarian economy which would cause an irrevocable 
divorce of the workers from access to means of production. It was suggested that this prevailing "peasant option" served to hold back the consolidation of the working class as a class, especially with the view of its expected reaction to a possible situation of crisis and confrontation with capital. The actual consolidation of the class, however, was also stressed, including the growth of class consciousness, in terms of the identification of own class interests as well as those of the opposing class of "bosses".

The general repression of workers' organisations and the absence of any significant element of workers' control or participation in management were noted. Views differed, however, on the significance to be attributed to these facts in terms of the class orientation of the state industrial sector. From one point of view, the absence of workers' control was seen as reflecting in part the weakness of the working class rather than any advanced forms of repression, but partly more general problems, unsolved in countries with long-established socialist traditions, as well. It would therefore be premature, according to this position, to deny the Tanzanian experience the claim of socialist orientation on that basis alone. From a different point of view, however, the repressive hierarchical work organisation of the parastatal industrial sector expressed a state-capitalist mode of production, geared to the advance of the class interests of the emerging bureaucratic-managerial ruling class and its corporate multinational allies, preempting any such claim of socialist orientation.

We also discussed the structure of industrial output in the state sector and its changes over time. Particular importance was attributed to the continued dominance of the processing industry, based on the traditional colonial-export economy. The large share of luxury consumer goods and the virtual absence of a producer-goods industry were also noted as unprogressive features. It was agreed that a socialist oriented strategy required major changes in this respect. It was also agreed that this unprogressive structure was largely determined by the nature of the alliance between foreign capital and local ruling groups. It was similarly maintained that the structural composition of industrial output has not undergone any significant changes since Independence. This proposition, however, was questioned. There was also a difference of opinion on the capacity of the present ruling group to effectuate changes in this respect.

To conclude, one may repeat some of the main propositions and counterpropositions. It was maintained, on one hand, that the Tanzanian state industrial sector cannot be regarded as part of a socialist oriented process of development for the following principal reasons:

(1) The parastatal sector is generating an increasing dependence of the economy as a whole on multinational capital;

(2) The parastatals are marked by heightening class contradictions between an emerging bureaucratic ruling class and the working class, with increasing repression and the absence of workers' control;

(3) The state industrial sector has not resulted in any structural changes in the orientation of production. group:

The following were the main counterpropositions argued in the

(1) Participation by foreign capital in the parastatal sector is partly inevitable and does not rule out the maintenance of a socialist oriented option;

(2) Workers' control may be a vital aspect of socialist development in a longer perspective but it could not be regarded as a necessary condition for socialist oriented advances at the present stage;

(3) The bureaucratic-managerial stratum cannot be treated as a ruling class which must be overthrown before socialist oriented changes can 
take place. (Although it was agreed that under all circumstances a fundamental contradiction exists between the workers and the state as the vehicle of state capital).

(4) The growth of the state industrial sector represented by itself a significant structural change, especially in combination with the simultaneous obstruction of the advance of a private capitalist class.

Despite these important disagreements, we concluded that in order to be able to establish the class character of the Tanzanian state and the state industrial sector it is necessary to seek to reconcile the following three, partly reinforcing, partly contradictory facts, which were not disputed by any side:

(1) The increase in imperialist surplus appropriation as a result of the role of the MNCs in the parastatal sector;

(2) The repression of working class organisations;

(3) The obstruction of the growth of a local private capitalist class.

Report from working group IV

Agricultural transformation and socialist orientation - an

indicental or decisive relationship?

Chairmen/rapporteurs: Lionel Cliffe, England, Tetteh Kofi, USA. Participants: J. Nowicki, P. Khalatbari, Karsten Jensen, Ritva Kivikkokangas, Helena Tuomi, Eva Eklund, Christer Krokfors.

This working group discussed the following sets of issues:

(1) Analysis of the existing structures and modes of production in the African economies;

(2) Strategies of transforming agrarian economies to socialism via the non-capitalist development'path;

(3) Theoretical and empirical analysis of the Somalian non-capitalist development path.

The first part of the paper presents a brief summary of what was done at the two sessions of the working group; and the second part summarises the theoretical and empirical analyses of the three issues stated above.

The group began the discussion with general comments and analyses of the nature and dynamics of relative underdevelopment in African economies within worlwide capitalist development. Next we discussed the nature and reasons for the under-utilization of labour and how this labour can be harassed to produce agricultural marketable surplus. It was also recognized that this surplus can, and in most cases a disproportionate share of it, is appropriated by the indigenious capitalist class and also by multinational corporations within the marketing channels. A theoretical exposition of the processes of development and underdevelopment within the Marxian model of simple and expanded reproduction was presented by Parviz Khalatbari. He essentially presented the main theoretical arguments in his paper.

This was followed by an empirical analysis of the processes of underdevelopment and relative impoverishment of small farmers via usury capital. This discussion was led by Josef Nowicki, who presented sections of his paper. 
The analysis of unequal exchange in production and distribution relations led us to the analysis of the role of multinational corporations in underdevelopment in African economies. Attention was focussed on food production and two papers were designated to be read for discussion the following day. The papers were: 1 . Tetteh $A$. Kofi, on Understanding Food-Aid and Agricultural Crisis in the Third World 1954-1975; and 2. Peter Wallensteen, Scarce Goods as Political Weapons: the Case of Food. The two papers. were discussed briefly with Tetteh Kofi leading the discussion and presenting a summary of the above papers.

The second session began with a discussion of the paper written by Tetteh Kofi.. First Kofi presented a summary analysis of his article. This was followed by contributing comments by the members of the group. This presentation was followed by a discussion of feasible strategies for transforming the agrarian African economies into industrialized socialist economies. Somalia was used as a case study in order to posit the theoretical analysis into a concrete case for empirical investigations. Members of the group made important theoretical contributions to the attempts to develop a theoretical and feasible model to transform the pastoral economy of Somalia into an industrialized non-capitalist economy .

Several theoretical questions were posed at the working group. Some of these questions may be grouped under the following categories:

(1) What do we mean by non-capitalist development? What are the political, and economic social changes that a society has to satisfy before it can follow a non-capitalistic path of development?

(2) What are the mechanisms that lead to relative impoverishment of the pre-capitalist sector as the capitalist sector deepens? How do we determine the optimal choice of technique between labor intensive and capital intensive modes of production so as to make the development process less painful? How can Africa prevent the advanced capitalist countries from using food-aid as a political weapon? How can the development countries control the activities of the multinational corporations?

(3) What are the different agricultural development strategies that will ensure that optimal transformation can take place? How can marketable surplus be generated in the pre-capitalist sector to be used to finance the industrial sector? In the Somalian economic structure, how can we operationally transform the economy in the non-capitalistic way under a continual accumulation of marketable surplus in the dominant pastoral sector to finance the development process?

(4) What are the qualitative changes that take place in the social relations of production during the transition phases of non-capitalist development? How can the worker/peasant alliance be sustained and the dictatorship of the proletariat maintained in the transition period?

The above groups of questions were first discussed within à theoretical framework; and then applied to the empirical experience of Somalia.

The participants contributed to a delineation of operationally feastble strategy of transforming pastoral economics via generation of marketable surplus, release of surplus labour in order to finance non-agricultural activities. The role of the government in infrastructural improvement in resource inputs for the nomads was stressed. This ranged from the planting leguminous plants and introducing of grasses which are assoclated with free nitrogen fixers in order to ensure quality pasture land with natural nitrogen fixation to the prevention of pastoral clans of monopolization of factor inputs such as water-wells. 


\section{Concluding remarks}

The working group felt that the concept of non-capitalist development needed a rigorous economic analysis. The concept as presently defined is too diffuse to have any operational value. More work need to be done to delineate rigorously the processes of relative impoverishment of the pre-capitalist sector. More important, however, is to develop strategies to transform and raise the productive forces of the pre-capitalist sectors of the African economies so that these sectors can contribute optimally to the development of the continent. This will entail a strategy to prevent external and internal exploitation of the labour power of the majority of the present population. The non-capitalist strategy must ensure equitable distribution of national income. 
Mai Palmberg

\section{LITERATURE ON NON-CAPITALIST DEVELOPMENT}

A selective bibliography on works available in English, French, German and the scandinavian languages.

Academy of Sciences of the USSR, Institute of the International WorkingClass Movement, The Working Class - Vanguard of the World Revolutionary Forces. 252 pp. Moscow: Novosti Press Agency Publishing House (no date).

Afanasyer, V., \& Makarova, M., \& Minayev, L., Fundamentals of Scientific Socialism. $317 \mathrm{pp}$. Moscow: Progress Publishers 1969 .

Alexendel, Ruth, a.o., eds., Asien und Afrika im revolutionären Weltprozess. $380 \mathrm{pp}$. Berlin: Akademie Verlag 1973. Studien über Asien, Afrika und Lateinamerika herausgegeben vom Zentraler Rat für Asien-, Afrika- und lateinamerikawissenschaften in der DDR, Band 3 und 4 .

Alexendel, Rutdh, ed., Nichtkapitalistischer Entwicklungsweg; Aktuelle Probleme in Theorie und Praxis. $439 \mathrm{pp}$. Berlin: Akademie Verlag 1972. Studien über Asien, Afrika und Lateinamerika herausgegeben vom Zentraler Rat für Asien-, Afrika- und Lateinamerikawissenschaften in der $\mathrm{DDR}$, Band 1 .

Alitovsky, S., "The Agrarian Question in the Countries of Asia and Africa" (book review), Social Sciences, No. 2(4) 1971, pp. 222-224.

Die Arbeiterklasse in Asien und Afrika; Formierung und Kampf 575 pp. Berlin: Akademie-Verlag 1974. Studien über Asien, Afrika und Lateinamerika herausgegeben vom Zentraler Rat für Asien-, Afrikaund Lateinamerikawissenschaften in der DDR, Band 13.

Belenky, A., "The Comintern and the East. The Struggle for the Leninist Strategy and Tactics in the National-Liberation Movement" (book review), Social Sciences, no. 2 (4) 1971, pp. 217-221.

Brehme, G., a.o., eds., Partei und Staat in den Ländern mit Sozialistischer orientierung. 272 pp. Berlin: Akademie-Verlag 1974. Studien uber Asien, Afrika und Lateinamerika herausgegeben vom Zentraler Rat für Asien-, Afrika- und Lateinamerikawissenschaften in der DDR, Band 11 .

Bulgarian Academy of Sciences, Research Centre for Africa and Asia, Developing Countries on the Non-Capitalist Road. Proceedings of the Third International Conference of Africanist Marxists of the Socialist Countries in Varna, September 5-12, 1971. Sofia: Publishing House of the Bulgarian Academy of Sciences 1974.

Documents from the 1969 Moscow Conference, APN 1969.

Ernst, Klaus, Tradition und fortschritt im afrikanischen Dorf: Soziologische Probleme der nichtkapitalistischen Umgestaltung der Dorfgemeinde in Mali. 354 pp. Berlin: Akademie-Verlag 1973. Studien über Asien, Afrika und Lateinamerika herausgegeben vom Zentraler Rat für Asien-, Afrika- und Lateinamerikawissenschaften in der DDR, Band 6 .

Gafurov, B., "The National-Liberation Movement at the Present Stage", Social Sciences, No. 2 (4) 1971, pp. 109-116. 
Griening, Horst, a.o., eds., Industrialisierung in Entwicklungsländern; Bedingungen, Konzeptionen, Tendenzen. $680 \mathrm{pp}$. Berlin: AkademieVerlag 1975. Studien iber Asien, Afrika und Lateinamerika herausgegeben vom Zentraler Rat für Asien-, Afrika- und Lateinamerikawissenschaften in der DDR, Band 7 .

Hutschenreuter, Klaus, "Stand und Entwicklungsperspektiven der nationalen Befreiungsbewegung im subsaharischen Afrika", Marxistische Blätter (Frankfurt am Main), No. 3, 1973.

Iskenderov, A., Africa: Politics, Economy, Ideology. 159 pp. Moscow: Progress Publishers 1972.

Khalabatbari, Parviz, ökonomische Unterentwicklung. Frankfurt am Main: Verlag Marxistische Blätter $197 \overline{2}$.

Kiva, A., "Countries of Socialist Orientation: Some Aspects of their Political Development", International Affairs (Moscow), No. 10, October 1973, pp. 30-37.

Kiva, A., "Experience of Non-Capitalist Development in Africa", International Affairs (Moscow), No. 5, 1972.

Lénine et la lutte révolutionnaire des peuples de l'Orient, APN Moscow 1969 .

Levkovsky, A., "The Third World Countries: Their Multiform Economic Structures", Social Sciences, No. 2 (4), pp. 156-164.

Manchka, Pyotr, Africa on the New Road. 184 pp. Moscow: Novosti Press Agency Publishing House 1972.

Mirski. Les Problèmes du mouvement de liberation nationale, APN 1971.

"New Stage in the national liberation movement. Problems of antiimperialist unity". World Marxist Review, No. 11, 1972, pp. 17-30.

Palmberg, Mai, "Icke-kapitalistisk utveckling?", Häften för Kritiska Studier, No. 1, 1973, pp. 3-28. Available in English under the title "Non-Capitalist Development?" (mimeo.)

Palmberg, Mai, Problems in the Theory of Non-Capitalist Development, 23 pp. Uppsala, April 1975 (mimeo.)

Pavlov, V.I., \& Redko, I.B., \& Ulyanovsky, P.A., Asia and Africa: Fundamental Changes. 384 pp. Moscow: Novosti Press Agency Publishing House 1972. Also available in French: L'Asie et I'Afrique: Changements Radicaux.

Popov, Y., Political Economy and African Reality. 152 pp. Moscow: Novosti Press Agency Publishing House 1967.

Pothekin, I.I., "On African Socialism: A Soviet View", in African Socialism, Friedland, William \& Rosbey, Carl G., eds., pp. 97-112. Stanford, California: Stanford University Press 1964.

Pushnov, Alexander, "The Experience of Mongolia", New Times, No. 28/1971, pp. $6-7$.

Simonia, Nodary, Socialist-oriented Development and National Democracy. 55 pp. Moscow: novosti Press Agency Publishing. House 1974. 
Slovo, Joe, "A Critical Appraisal of the Non-Capitalist Path and the National Democratic state in Africa", Marxism Today, June 1974.

Solodovnikov, V.G., Africa Fights for Independence, APN, Moscow, 1970 .

Solodovnikov, V.G., \& Bogoslovsky, V., Non-Capitalist Development; An Historical Outline. 252 pp. Moscow: Progress Publishers 1975.

Solodovnikov, V.G., The present stage of the non-capitalist development in Asia and Africa. (A Report at the International Conference The experience of the socialist transformations in the USSR and its international significance', Tashkent, October 16-19, 1972). 70 pp. Moscow: Soviet Afro-Asian Solidarity Committee 1972. (mimeo.)

Solodovnikov, V.G., "Some Aspects of Non-Capitalist Development", International Affairs (Moscow), No. 6, 1973.

Solodovnikov, V.G., "Some Feature of the African Countries' NonCapitalist Development", Social Sciences, No. 2 (4), pp. 117-1129.

Starushenko, Gleb, Africa Makes a Choice. $119 \mathrm{pp}$. Moscow: Novosti Press Agency Publishing House 1975. Available in French: La Choix de l'Afrique.

Szentes, Támas, The Political Economy of Underdevelopment. $328 \mathrm{pp}$. Budapest: Akađémiai Kiađó 1971.

Tshume, Albert, "Africa's Revolutionary Way Forward", African Communist, No. 51, 1972, pp. 94-110.

Tshume, Ablert, "The Non-Capitalist Path in Africa", African Communist, No. 52, 1973, pp. 40-55.

Tyagunenko, V., "Prospects of National-Liberation Revolutions", Social Sciences, No. 2 (4), pp. 144-155.

Ulyanovsky, R., "The contemporary National-Liberation Movement and the Peasantry", Social Sciences (USSR Academy of Sciences, Department of Social sciences), No, $2(8), 1972$, pp. 104-136.

Ulyanovsky, R., "Leninism, Soviet Experience and the Newly Free Countries", New Times, Nr. 1/1971, pp. 18-21, and Nr. 2/1971, pp. 20-24 .

Ulyanovsky, R., "The Leninist Concept of Non-Capitalist Development and Our Time", Social Sciences, Nr. 2/1971, pp.91-108.

Ulyanovsky, R., Socialism and the Newly Independent Nations. 562 pp. Moscow: Progress publishers 1974.

Vladin, A., National Personnel: Its Importance for Developing Countries. 64 pp. Moscow: Novosti Press Agency Publishing House 1975.

Volkov, M., Industrialization for national economic independence. 77 77 pp. Moscow: Novosti Press Agency Publishing House 1974.

Voronov, A., "Soviet Central Asia and the Developing Countries", New Times, Nr. 37/1971; pp : 10-11.

Woddis, Jack, Africa, the Way Ähead. 174 pp. New York: International Publishers $\overline{1963 .}$

Zhukov, Y., \& Delyusin, I., \& Iskenderov, A., \& Stepanov, L., The Third World: Problems and Prospects. 275 pp. Moscow: Progress Publishers 1976 . 


\section{CONTRIBUTORS}

Mohamed Aden

P.O. Box 561

Mogadishu

Somali Democratic Republic

A.M.M. Ashur

P.O. Box 1554

Mogadishu

Somali Democratic Republic

Jeremy Gould

Institute of Development studies

Unioninkatu $40 \mathrm{~B}$

SF-00170 Helsinki 17

Finland

Parviz Khalatbari

Humboldt Universität zu Berlin

Sektion Wirtschaftswissenschaften

Bereich Politische ökonomie

Lehrstuhl Demographie

Spandauer Strasse 1

D-108 Berlin

German Democratic Republic

Riitta Launonen

Institute of Development studies

Unioninkatu $40 \mathrm{~B}$

SF-00170 Helsinki 17

Finland

Peter Mandi

Institute for World Economics

Hungarian Academy of Sciences

P.O. Box 36

H-1531 Budapest

Hungary

Jozef Nowicki

Research Institute for Developing

Countries

Central School of Planning and

Statistics

ul. Rakowiecka 24

Warsaw, Poland
Mai Palmberg

The working group for studies of

development strategies in the

third world

c/o The Scandinavian Institute of

African Studies

P.O. Box 2126

S-750 02 Uppsala

Sweden

Lars Rudebeck

Department of Political science

Uppsala University

P.O. Box 514

S-751 20 Uppsala

Sweden

Timothy Shaw \& Malcolm Grieve

Department of Political Science

DaIhousie University

Halifax, N.S., Canada

Joe Slovo

13 Lyme street

London N.W. 1

England

Clive Y. Thomas

Department of Economics

University of Guyana

Box 841 .

Georgetown, Guyana

Jack Woddis

149, Coventry Road

Ilford, England

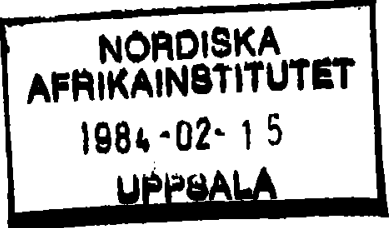





